\title{
Phylogeny, phylogeography and population connectivity of Lessonia \\ (Phaeophyceae)
}

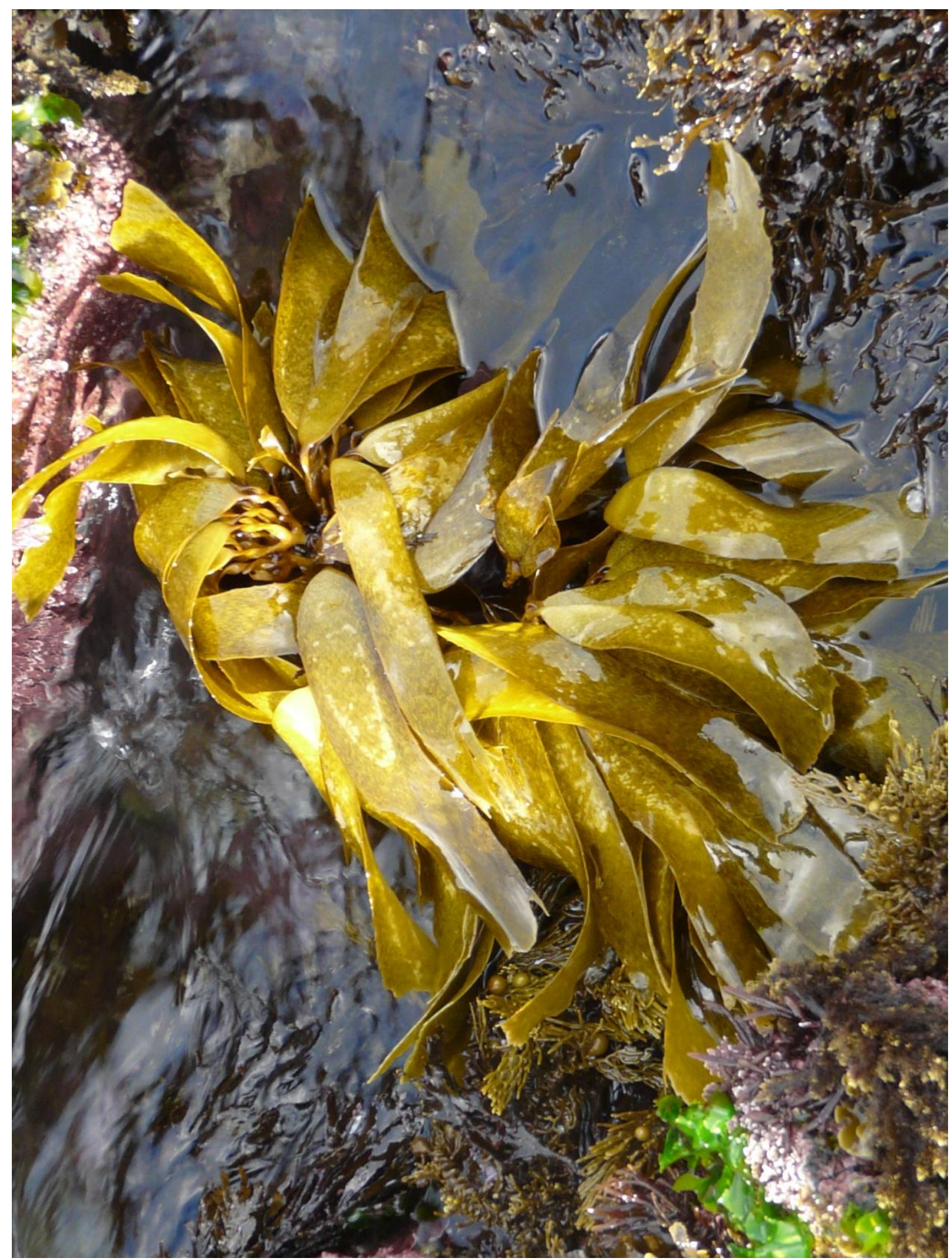


Cover: Lessonia variegata in the lower intertidal of Moa Point, Wellington. 


\title{
Phylogeny, phylogeography and population connectivity of Lessonia (Phaeophyceae)
}

by

\section{Peter Martin}

\author{
A dissertation \\ submitted to Victoria University of Wellington \\ in fulfilment of the \\ requirements for the degree of \\ Doctor of Philosophy \\ in Ecology and Biodiversity
}

\section{Victoria UNIVERSITY OF WELLINGTON Te Whare Wānanga o te Ūpoko o te Ika a Māui}

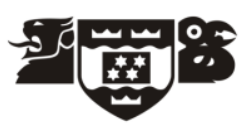

Victoria University of Wellington

Te Whare Wānanga o te Úpoko o te Ika a Māui 



\section{Abstract}

The brown algal genus Lessonia is distributed in the Southern Hemisphere where it can form dominant kelp beds on the exposed rocky shores of New Zealand, South America and Tasmania. Its disjunct distribution within the West Wind Drift contrasts with the view that it is a poor disperser. Apart from studies in Chile, where it is an economically important genus, little is known about Lessonia and in some areas even the number of species is unknown. Using different genetic markers I examined the phylogeny, phylogeography, and the connectivity of populations in Lessonia. Using the literature, species affiliations and nomenclatural problems have been investigated. Combining the sequences of three mitochondrial, one chloroplast and two nuclear markers, a supermatrix approach was used to investigate the phylogenetic relationship and the timing of speciation for all known Lessonia species. The Australasian Lessonia species form a clade within a paraphyletic grouping of South American species. Radiation in Lessonia occurred about 5 Mya at the beginning of the Pliocene and rapid radiation took place in Australasia 3.5 Mya. The data also revealed cryptic species within a $L$. variegata species complex. Further analysis within the Australasian clade, using mitochondrial (atp8-sp) and chloroplast (rbc-sp) markers and wider sampling (469 individuals from 57 sample sites) supported four cryptic species and revealed localized distribution for all Australasian lineages. Genetic breaks between Lessonia lineages corresponded well to known biogeographic regions and could be correlated to the geographic structure of New Zealand at the end of the Pliocene. The Cook Strait region was analysed more closely with newly developed microsatellite markers to test the influence of geographic breaks (Cook Strait and Palliser Bay) on the connectivity of populations. 
The results suggested that connectivity depends on the width of unsuitable habitat, and within inner Cook Strait it is facilitated by sometimes strong tidal flows that create turbulences and unique current patterns. The results implied that rafting is an important mean of dispersal. The study of the early literature on Lessonia supported the new lectotypification of L. flavicans but revealed that L. frutescens and possibly L. ovata (supported by images of rediscovered herbarium material) are synonymous to L. searlesiana and as the older epithets they should have priority. Suggestions have been made for the lectotypification of $L$. fuscescens and L. ovata. In general Lessonia shows non-overlapping distribution in Australasia but overlapping distribution in South America. Despite being a poor disperser, indicated by fine scale genetic structure, Lessonia is also able to connect populations over wide areas of unsuitable habitats. 
für Waltraud und Ludwig 


\section{Acknowledgements}

I have to mention red-hatted Jacques-Yves Cousteau as the person who planted an interest in marine biology into the mind of a very young Peter Martin. I am very grateful to my parents, who stood behind me and even showed excitement when I finally decided to follow my dreams and changed my professional career into an academic one with an uncertain future.

Now at the end of my $\mathrm{PhD}$ I want to thank all the people I met along the way, who inspired me and helped me achieving my goal. These are my fellow students from the Universities in Halle, Rostock and the Victoria University in Wellington, the teachers and lecturers I enjoyed at these Institutions and my $\mathrm{PhD}$ supervisors at Victoria University. I also want to show gratitude to the three examiners of this thisis, Sharyn Goldstien, Ken Ryan, and John Bolton.

I like and thank my best friends that have also been listeners and tellers of scientific fictions, Kai Ziervogel, Christian Bödeker, Rudi Schnitzler, Marc Hasenbank, and Elizabeth Heeg.

Last but most important of all I want to thank the people I love and without their help nothing would have been possible. These are my mother, Waltraud, my father, Ludwig, my brother, Jochen, and my partner, Walli (and the apes Wumbaba and Wum). 
Acknowledgements to Chapter 2

I am grateful to Ceridwen (Crid) Fraser, Cesar Cardenas, Christian Bödeker, Christopher Lane, Erasmo Macaya-Horta, Joe Buchanan, Loa Hunt, Robyn Dunmore, and Wendy Nelson for providing algal material. I also appreciate the efforts of Heroen Verbruggen and two anonymous reviewers for the Journal of Phycology for a critical reading of previous versions of this manuscript. This research was funded through a scholarship from the Victoria University of Wellington.

Acknowledgements to Chapter 3

I am grateful to Christian Bödeker, Don Neale, Erasmo Macaya-Horta, Gert \& Christine Vermeer, Joe Buchanan, Loa Hunt, Nick Shears, Robyn Dunmore, Waltraud Schiedermair and Wendy Nelson for helping with the sampling and/or providing algal material. I am thankful to the Wellington Botanical Society for grants to ease the cost of travelling. This research was partially funded by the Department of Conservation New Zealand and through a scholarship from the Victoria University of Wellington.

Acknowledgements to Chapter 4

This project was partially funded by the Department of Conservation New Zealand and through a scholarship from the Victoria University of Wellington. I am grateful 
to Lara Shepherd, Joe Buchanan, and Erasmo Macaya-Horta for their help in microsatellite library construction.

Acknowledgements to Chapter 5

The extensive samplings have only been possible with the help of self-giving Waltraud Schiedermair and also Erasmo Macaya-Horta. I want to thank the caretaker of the Fighting Bay Cable Station for granting excess to the bay and the management of Meridian Energy for providing escort to Cape Terawhiti.

Acknowledgements to Chapter 6

The curators of the following herbaria have been helpful in providing specimens or high quality images of Lessonia collections: BM, PC, S, TCD, UC and US. I am especially grateful to Paul Silva and Kathy Ann Miller from UC who helped with taxonomic questions and provided images of anatomic sections, and to Bruno de Reviers who sent me an early manuscript of his research. I am also grateful to Phil Garnock-Jones for helping in dealing with the International Code of Botanical Nomenclature. 


\section{Table of Contents}

Abstract

Chapter 1 Introduction \& overview............................... 1

1.1 Thesis structure ..............................................................................................

1.2 Lessonia - First descriptions and biogeography ............................................

1.2.1 Distinguishing features of Lessonia species and their synonyms .......... 9

1.2.1.1 Australasian species ........................................................... 9

1.2.1.2 South American species ...................................................... 11

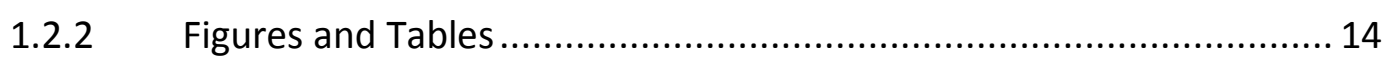

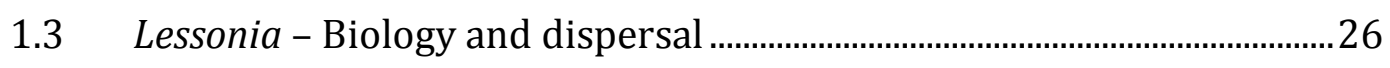

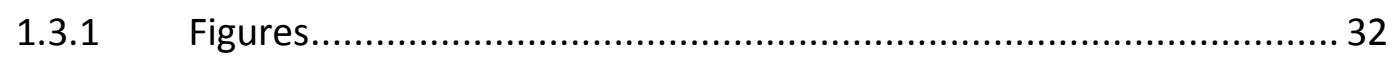

1.4 Lessoniceae - New molecular taxonomy and phylogeny ...........................34

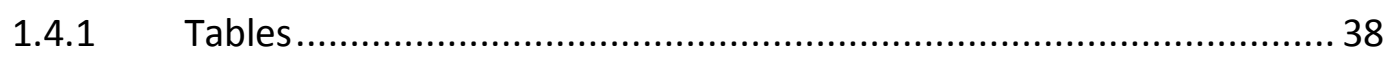

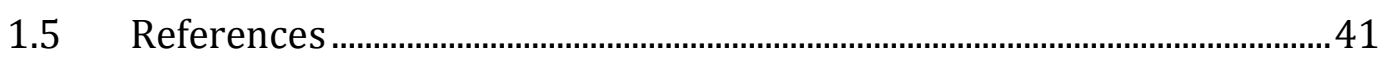

\section{Chapter 2 Molecular Phylogeny and timing of radiation in Lessonia (Phaeophyceae, Laminariales) ...53}

2.1 Abstract................................................................................................................ 53

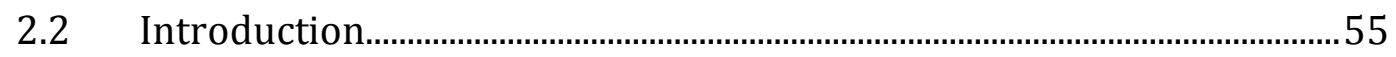

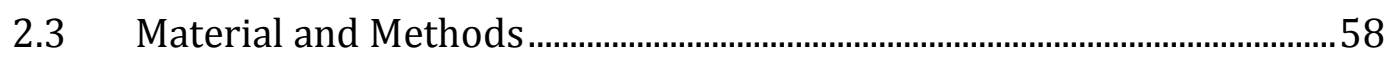

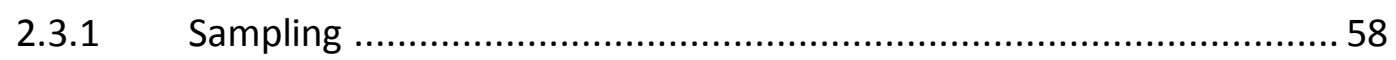


2.3.2 DNA extraction, amplification, and sequencing ............................5 58

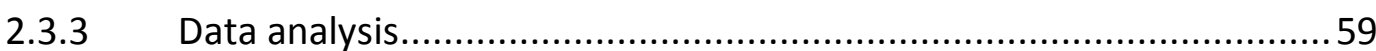

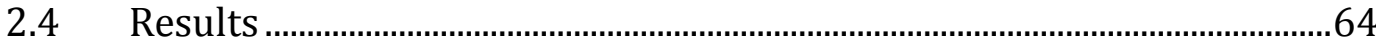

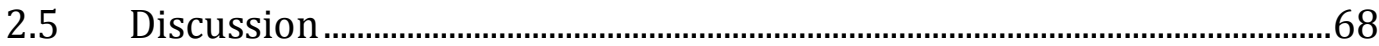

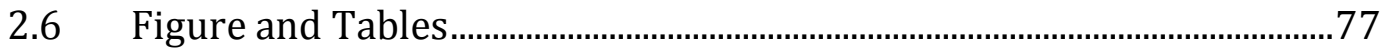

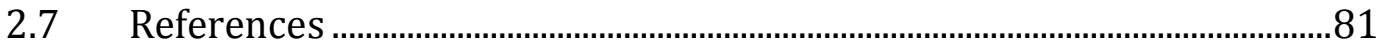

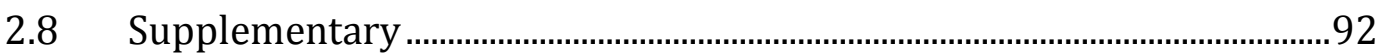

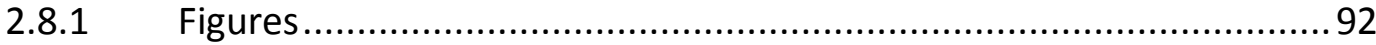

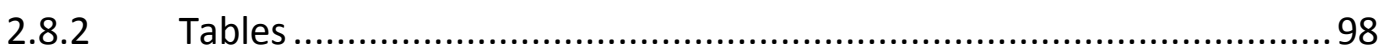

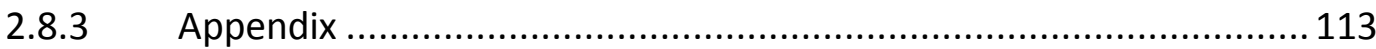

\section{Chapter 3 Phylogeography of Lessonia (Phaeophyceae,} Laminariales) in Australasia.........................................117

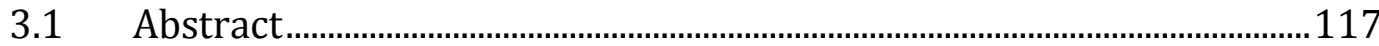

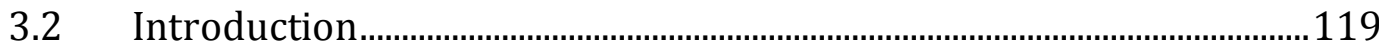

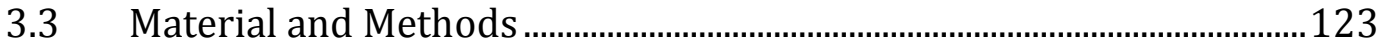

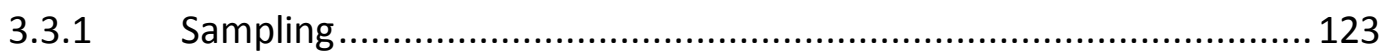

3.3.2 DNA extraction, amplification, SSCP and sequencing .................... 123

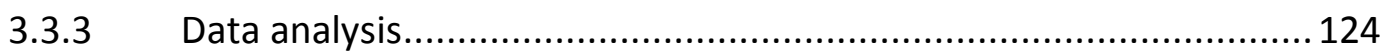

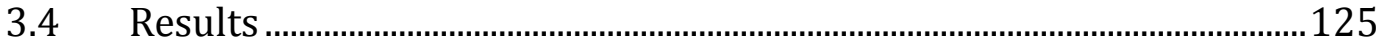

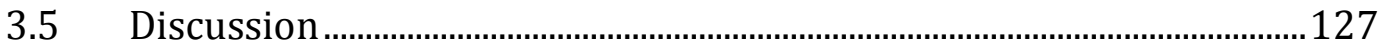

3.5.1 Distribution and Bioregions ................................................. 128

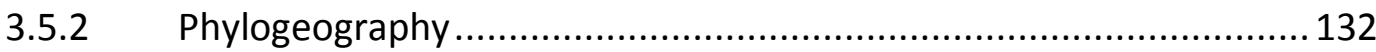

3.5.2.1 Ancient component (relationships between species and

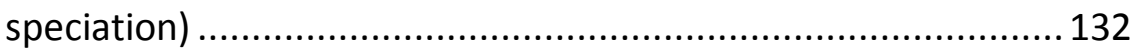

3.5.2.2 Recent component (phylogeographic structure within species) 135

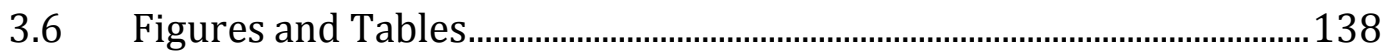

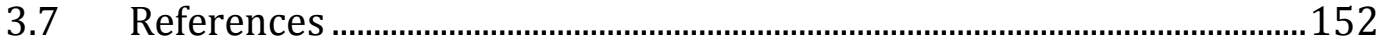

Chapter 4 Characterisation of microsatellites in the Southern Hemisphere kelp Lessonia variegata (Phaeophyceae, Laminariales).......................................161

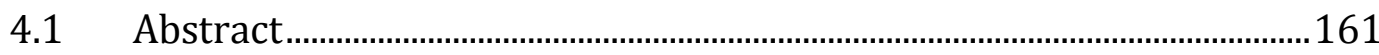




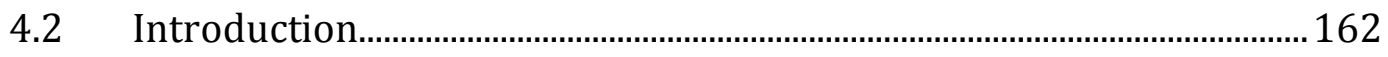

4.3 Material and Methods ................................................................................. 163

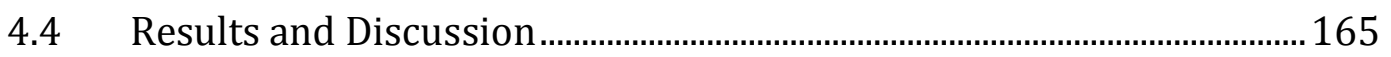

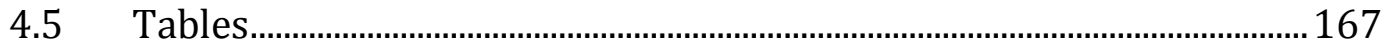

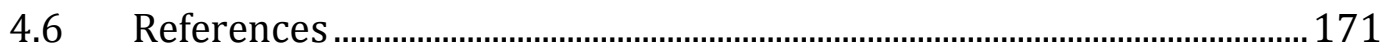

\section{Chapter 5 Connectivity between populations of} Lessonia variegata (Phaeophyceae, Laminariales) across Cook Strait, New Zealand ................................ 177

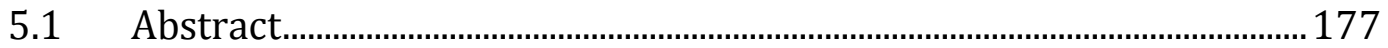

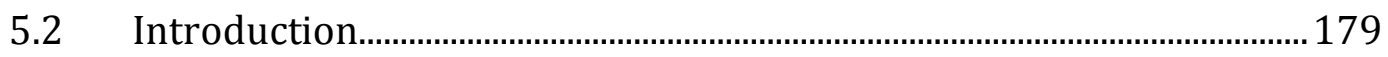

$5.3 \quad$ Material and Methods ................................................................................... 181

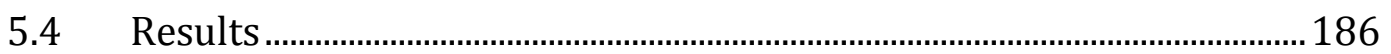

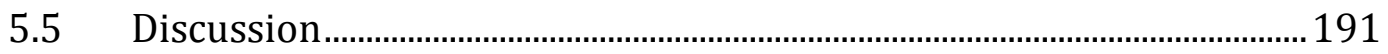

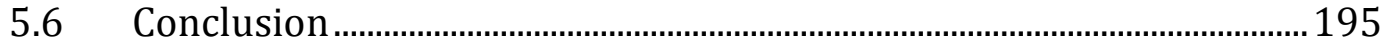

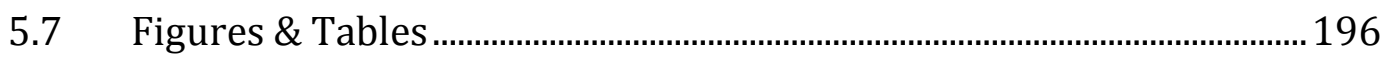

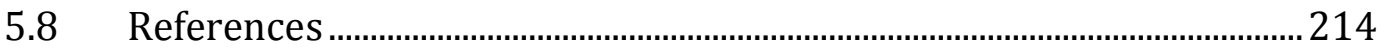

\section{Chapter 6 Taxonomic confusion in Lessonia from the}

\section{Falkland Islands................................................................ 221}

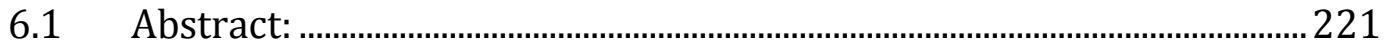

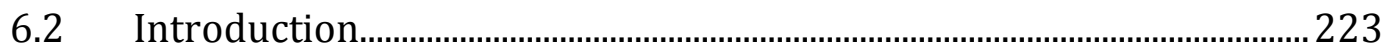

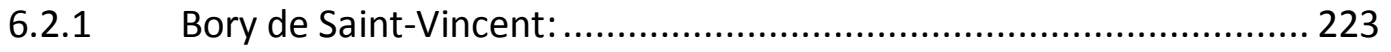

6.2.2 Joseph Dalton Hooker \& William Henry Harvey .............................. 225

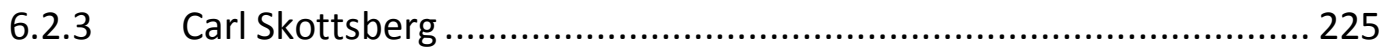

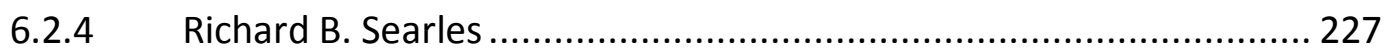

6.2.5 Aldo Asensi \& Bruno de Reviers ............................................... 228

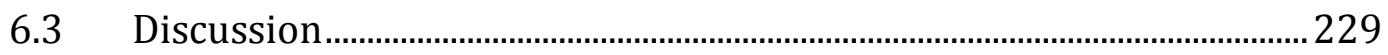

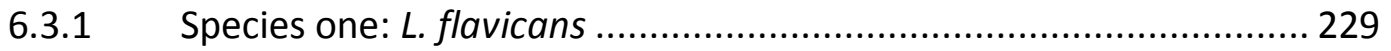

6.3.2 Species two: L. fuscescens [?], L. ovata, (L. frutescens, (L. searlesiana))

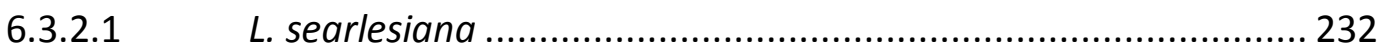




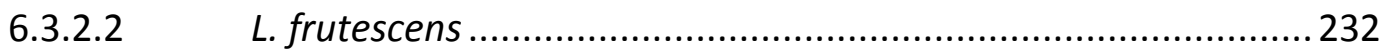

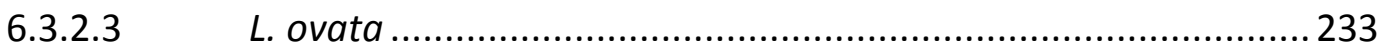

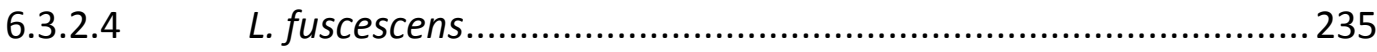

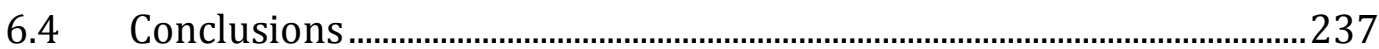

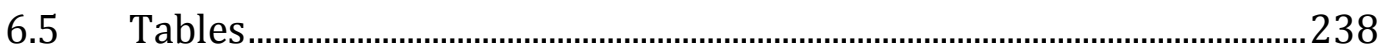

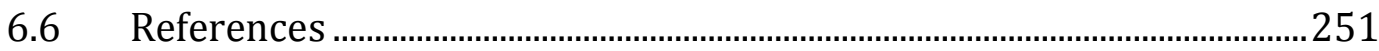

\section{Chapter 7 Summary and directions for future research} .........................................................................257

7.1 What processes maintain genetic breaks in the distribution of Lessonia

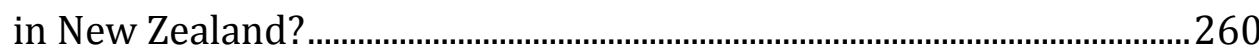

7.2 How important is rafting as a means of dispersal in Lessonia? ...........262

7.3 How many Lessonia species are there?....................................................263

7.4 Where did Lessonia originate? ...................................................................22

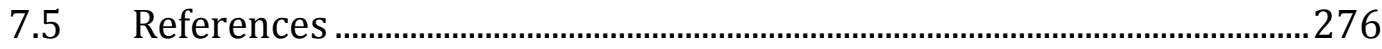




\section{List of Figures}

Fig. 1.1 Distribution of L. nigrescens and L. trabeculata. 14

Fig. 1.2 Vertical distribution of Lessonia species in central Chile. L. nigrescens (black) shares the intertidal with Durvillaea antarctica (orange); $L$. trabeculata (white) is found in the subtidal $(0.5-20 \mathrm{~m})$ above and between Macrocystis pyrifera (green). 14

Fig. 1.3 Distribution of L. ovata (=L. flavicans sensu Searles) and L. flavicans. .... 15

Fig. 1.4 Vertical distribution of Lessonia species in south Chile (Patagonia). L. nigrescens (black) shares the intertidal with Durvillaea antarctica (orange); L. flavicans (yellow) is found in the subtidal (0.5-2 (15) m) above a belt of Macrocystis pyrifera (green) whereas L. ovata (brown) is found below the Macrocystis belt (2-20). It is possible that L. flavicans might become bigger or as big as L. ovata (see Fig. 1.5 and photographs in Fig. $1.6 \& 1.7$ ). 15

Fig. 1.5 Vertical distribution of Lessonia species at the Falkland Islands. L. flavicans (yellow) can develop into huge algae several meters in height (up to $8 \mathrm{~m}$ with trunks as thick as a human thigh (d'Urville 1825)) and is found in the subtidal (0.5-15m) above and between Macrocystis pyrifera (green) whereas L. ovata (brown) is usually found deeper (?-20) and might develop in big algae $4 \mathrm{~m}$ in height. No L. nigrescens is found at the Falkland Islands but $L$. flavicans might have extended its range into the intertidal, where it is found between Durvillaea antarctica (orange). In the intertidal L. flavicans shows a slightly different morphology with round and more flexible stipes that look similar to the stipes of the intertidal L. nigrescens from the mainland (see photographs in Fig $1.6 \& 1.7$ ). 
Fig. 1.6 Pictures of Lessonia ovata on the Falkland Islands (A-C) and Patagonia (DF), showing different morphologies. The pictures on the Falkland Islands were taken at a depth of $20 \mathrm{~m}$. (Photos provided by K. Neely (A-C), and C. Cardenas (D-F))

Fig. 1.7 Pictures of Lessonia flavicans on the Falkland Islands, showing different morphologies. A) intertidal together with Durvillaea antarctica. A single intertidal L. flavicans is shown in the insert. Note that even if the stipes appear similar to the stipes of L. nigrescens, the holdfast morphology is different to the one found in L. nigrescens, B-F) subtidal morphologies showing exceptionally big thalli extending above the canopy (D). (Photos taken by C. Fraser (A), or given by K. Neely (B-F)).

Fig. 1.8 Distribution of Lessonia in Australasia showing restricted distribution with no overlapping species ranges 19

Fig. 1.9 Distribution of Lessonia in Australasia. Lessonia (white) is found in the subtidal below Durvillaea antarctica (orange) till 10-20m, depending on the species. Macrocystis pyrifera (green).

Fig. 1.10 Possible dispersal mechanisms in Lessonia. The different modes of dispersal include dispersal of propagules (spores and sperm), which is associated with the life cycle and mainly spans distances between $0-10 \mathrm{~m}$ (e.g., Norton 1992), however, spores have been detected 4km downstream of the source populations (Reed 1988). Saltation was investigated in Undaria pinnatifida where it was accounted for dispersal between 10100m/year (Sliwa et al. 2006). In the same study dispersal of drifting algae and algal fragments was assumed to span 100-1,000m/year. Rafting of gametophytes and sporophytes attached to floating devices might allow 
dispersal over distances $<100 \mathrm{~km}$ to $>5,000 \mathrm{~km}$ (Thiel \& Haye 2006).

Possible rafts for Lessonia are the two floating species Macrocystis pyrifera and Durvillaea antarctica, which have overlapping habitats with Lessonia.

Fig. 1.11 Durvillaea antarctica (orange in insert) overgrowing a Lessonia nigrescens (black in insert) holdfast. (Photo taken by C. Fraser).

Fig. 2.1 Distribution and sample sites of Lessonia. a) Global distribution of Lessonia. b) sample sites in Australasia and c) in southern South America. Sample ID given as four ID numbers (see Table S 2.1 for exact locations) followed by species designation; $\mathrm{ad}=$ L. adamsiae $($ The Snares), $\mathrm{br}=$ L. brevifolia (Campbell Is. \& Antipodes), co = L. corrugata $($ Tasmania), $\mathrm{fl}=$ L. flavicans sensu Searles (Falkland), ni $=$ L. nigrescens (Chile), th $=$ L. tholiformis (Chatham Is.), $\operatorname{tr}=$ L. trabeculata $($ Chile $), \mathrm{va}=$ L. flavicans (southern Chile \& Falkland), $\mathrm{K}=$ L. variegata $/ \mathrm{K}$ (northeastern South Is.), $\mathrm{N}=L$. variegata/N (northern North Is.), $\mathrm{S}=$ L. variegata/S (southern South Is.), W =L. variegata $/ \mathrm{W}$ (central New Zealand).

Fig. 2.2 Maximum-likelihood topology (TopoA) of the combined dataset (matrix-I). Scale bar $=$ substitutions per site. Sample abbreviations according to sample ID's from Table S 2.1. Support values are Bayesian posterior probabilities, ML bootstraps, MP bootstraps, and NJ LogDet bootstraps, respectively. “*” represents $100 \%$ support, whereas “_“" $=<0.95$ posterior probability or $<$ $70 \%$ bootstrap support. All methods resulted in a TopoA topology, however, only MP had support over 70\%. Abbreviations of L. nigrescens as in Tellier et al. (2009; N=northern lineage; IA=intermediate area). Arrow indicates the monophyletic Australasian group. Lessonia variegata is split 
into four lineages indicated with a lineage abbreviation after the back slash. $\mathrm{K}=$ Kaikoura lineage, $\mathrm{N}=$ northern lineage, $\mathrm{S}=$ southern lineage, and $\mathrm{W}=$ Wellington lineage.

Fig. 2.3 Bayesian tree (TopoB) of a relaxed clock model of the combined dataset (matrix-I) following calibration strategy $\mathrm{C}$ with mutation rates as priors. Bars and numbers in brackets showing $95 \%$ of the highest posterior density of the node height (indicating the tmrca of adjacent branches); mean node age is given as a vertical number; support values are posterior probabilities. Scale axes in Mya. Figure shows speciation within Lessonia ( $<5$ Mya) and a sudden radiation in the Australasian grade (ca. 3.5 - 3 Mya). .79

Fig. 3.1 Biogeographic regions and Lessonia sample sites (red dots). Yellow dots denote sites where no Lessonia have been found. R1-3 indicate sites where Lessonia is reported in the literature or from museum records. a) Biogeographic regions of the three main islands of New Zealand after Shears et al. (2008) based on presence and absence of macroalgae. b) Biogeographic regions implemented in the Marine Protected Areas Policy (MPA 2008) including The Snares, the Sub-Antarctic Islands, and the Chatham Islands. Note the differences at Cook Strait area; whereas Shears et al. (2008) divided this area into a western and eastern region (Able and Cook) MPA (2008) divided this area into a northern and southern region (North and South Cook Strait). A break at Cape Campbell (at site 27) is not assigned by Shears et al. (2008). 138

Fig. 3.2 Full median network $(\mathrm{e}=70)$ of the rbc-sp region showing star like evolution and ancient relationships among Australasian Lessonia. The network is rooted on South American species (L. nigrescens $(\mathrm{Ln})$, L. trabeculata (Ltr), 
and L. vadosa (Lvd)). All samples from L. variegata/S (Lv/S) and $L$. adamsiae (La) share the same haplotype as do L. variegata/W (Lv/W) and two samples of L. variegata/N (Lv/N) (see Table 3.1). Lb L. brevifolia, Lc L. corrugata, Lv/K L. variegata/K, and Lt L. tholiformis. 139

Fig. 3.3 Reduced median network of the atp8-sp region showing star like evolution within Australasian Lessonia. L. adamsiae (La) has an atp8-sp haplotype that is ancestral to L. corrugata (Lc) haplotypes. For the distribution of the haplotypes within Tasmania and New Zealand see Fig. 3.5 and 3.6 respectively. Lb L. brevifolia, Lt L. tholiformis, Lv/K L. variegata/K, Lv/N L. variegata/N, Lv/S L. variegata/S, and. Lv/W L.variegata/W. 140

Fig. 3.4 Haplotype distribution and atp8-sp network of L. variegata/W showing the relationship between haplotypes. Tripod indicates root position. Two closely related haplotypes (Lv/W and Lv/W2) are found geographically far apart at either the East Cape or throughout Cook biogeographic region. Recent southward dispersal of Lv/W3 and Lv/W4 haplotypes following the East Cape Current (ECC) is suggested. Lv/W haplotypes were found at sites 20 to 26 with increasing abundance in the Cook Strait area. Northward dispersal following the Wairarapa Coastal Current (WCC) is likely. Lv/W1 was only found at site 24. The East Cape Eddy (ECE) is thought to act as barrier for gene flow between Portland and Northeastern bioregion. The grey area in the centre of the North Island illustrates the cover of ignimbrite after the Kidnapper eruption 1 Mya (after Wilson et al. 1995). Site numbers correspond to the sites in Table 3.1 ..... 141

Fig. 3.5 Sample sites, haplotype distribution map and atp8-sp network of $L$. corrugata. Tripod indicates root position (this network is part of an 
Australasian network showing only the L. corrugata haplotypes, thus it is rooted). Two unrelated haplotypes are found in close proximity at Ladies Bay and Hobart. Two dispersal hypotheses have been tested, $\mathrm{H}_{\text {west }}$ (blue) and $\mathrm{H}_{\text {east }}$ (red). The two tested matrices differ in the geographic distance (colour coded) based on the dispersal hypotheses. A mantel test correlation coefficient supports $H_{\text {west }}$ (with $\mathrm{r}^{2}$ west $=0.93, \mathrm{p}_{\text {west }}=0.006 ; \mathrm{r}_{\text {east }}^{2}=0.13$, $\left.p_{\text {east }}=0.307\right)$. The haplotype distribution fits an explanation where out of a north western refugia $L$. corrugata dispersed at either side of Tasmania following the Zeehan Current or the Bass Strait Waters and East Australian current respectively (Bass Strait Current after Gibbs 1992) 142

Fig. 3.6 Atp8-sp haplotype distribution map. Circle size proportional to sample size (see size standard on the left) numbers in circles are sample site ID's. Purple line between site 27 (Cape Campbell) and 28 (Kekerengu) denotes area of upwelling. Species ranges are indicated by dotted lines. 143

Fig. 3.7 New Zealand at the Late Pliocene. Coloured lines show the current distribution of Lessonia variegata lineages. Green L. variegata/N, yellow/orange L. variegata/W, red L. variegata/K, and blue L. variegata/S. A) Plate movement $(\sim 30 \mathrm{~km} / \mathrm{My})$ leading to the Kaikoura Orogeny (King 2000) and the opening of Cook Strait (Lewis et al. 1994, Bruce 2009). B) With the retreat of the first ice age of the Pleistocene, the Canterbury Plains have been formed through glacial outwash and aggradations. They persisted during any subsequent glacial and interglacial period (Fleming 1979). C) The lower part of the North Island was submerged during the Pleistocene (e.g., Fleming 1979; fig. 19). D) Northland was a chain of unconnected islands (e.g., Fleming 1979; fig. 19). E) The south eastern part of the North 
Island was a long stretched island, neither connected to the rest of the North Island nor to the South Island (Lewis et al. 1994, Bruce 2009). F) Banks peninsula was a volcanic island (e.g., Fleming 1979, Stevens et al. 1995). G) In the south, Stewart Island was connected with the South Island and The Snares were either connected or very close to the mainland (e.g., Stevens 1980; fig. 16.36). Not shown) The Sub-Antarctic Islands were all present; three were of volcanic origin and the youngest was active till 1 Mya (Peat 2003). The rocks of the Chatham Islands can be dated to 130 Mya, however, they have been submerged during the Pliocene till 2-3 Mya (Holt 2008)

Fig. 5.1 Sample locations (stars) and different sample designs (A-C). Dark grey outlined is the distribution of Lessonia variegata/W in the area. Sampling design A was applied to Fighting Bay; sampling design B with increasing distances between sites (quadrats) was applied to the locations Cape Terawhiti, Moa Point, Turakirae Head, and Cape Palliser; sampling design C was used at Mataikona. 196

Fig. 5.2 Bar plot and graphs of the genetic population differentiation at the $1^{\text {st }}$ hierarchical level calculated in STRUCTURE. Bar plots show the mean of all replicates of $\mathrm{K}^{*}$ (here $\mathrm{K}=2$ ). Each population is represented by a colour and each sample is represented by a single bar showing its membership coefficient to any population (the height of each bar plot equals 100\%). Left graph shows the mean $\mathrm{L}(\mathrm{K})$ value, right graph shows $\Delta \mathrm{K}$ values using a modified transformation based on Evanno et al. (2005), which calculates the best value of $\mathrm{K}\left(\mathrm{K}^{*}\right)$. The height of the $\Delta \mathrm{K}^{*}$ value indicates the strength of 
xviii

the signal detected by STRUCTURE. CSC Cook Strait cluster, WC

Wairarapa cluster 197

Fig. 5.3 Bar plots and graphs of the genetic population differentiation at the 2nd hierarchical level calculated in STRUCTURE. See Fig. 5.2 for more details. GWG Greater Wellington group. 198

Fig. 5.4 Bar plots and graphs of the genetic population differentiation at the 2nd hierarchical level calculated in STRUCTURE. See Fig. 5.2 for more details. $\Delta \mathrm{K}$ values are not shown as $\mathrm{K}^{*}=1$ (i.e., no substructure was found). GWG Greater Wellington group. 199

Fig. 5.5 Bar plots and graphs of STRUCTURE results, testing connectivity within Cook Strait cluster. See Fig. 5.2 for more detail. $\Delta \mathrm{K}$ values are only shown if $K^{*}>1$ (i.e., when substructure was found). 200

Fig. 5.6 Bar plots and graphs of STRUCTURE results, testing connectivity to Cape Palliser. See Fig. 5.2 for more detail. 201

Fig. 5.7 Principle component analysis (PCA). Each point represents the centre of gravity of all samples per site. Total variance is given in parentheses. Fight, Fighting Bay; Tera, Cape Terawhiti; Moa, Moa Point; Tura, Turakirae Head; Pall, Cape Palliser; Mata, Mataikona. 202

Fig. 7.1 L. variegata/W displaying morphological features of the 'real' L. variegata; sampled at Lyall Bay in Wellington (Type locality); left: close up on blades showing variegation; middle: close up on buttress; right whole alga.

Fig. 7.2 L. variegata/N multiple stipes arose from a flattened holdfast; blades, which are normally uni-coloured show long and parallel variegations in some populations (left) 
Fig. 7.3 Multiple stipes emerge from the holdfast in L. variegata/K (left), but only a few from L. variegata/S (right; showing two algae).

Fig. 7.4 Transverse sections showing possible differences between the four $L$. variegata lineages as specified in Table 7.1 270

\section{Supplementary Figures}

Fig. S 2.1 PCR profiles for the fife markers used. Touchdown PCR was used for atp8-Sp and trnW-Sp; a simple PCR profile was used for nd6-gene, rbcSp, and ITS.

Fig. S 2.2 Slope of saturation curves for detecting saturation within a marker region.

Dashed line indicates the no saturation slope (i.e., uncorrected distances equal corrected distances). All markers, except the $3^{\text {rd }}$ position of the nd6gene, are slow evolving and weak saturated. The $3^{\text {rd }}$ codon position of the nd6-gene is medium fast evolving with intermediate saturation (after Verbruggen and Theriot 2008) (see also Table 1).

Fig. S 2.3 Bayesian topology (TopoB) using the second alignment (matrix-II). Scale bar $=$ substitutions per site. Sample abbreviations according to sample ID's from Table S1. Support values are Bayesian posterior probabilities, MP bootstraps, and NJ LogDet bootstraps, respectively. “*” represents $100 \%$ support, whereas ““_“ $=<0.95$ posterior probability or $<70 \%$ bootstrap support, except for the red numbers that support the root position. Only Bayesian and NJ resulted in a TopoB topology, however, 
without support. The MP-tree had an unsupported TopoA topology.

Abbreviations as in Fig. 2

Fig. S 2.4 NJ-LogDet topology (TopoB) of the combined dataset (matrix-I) with Laminaria ephemera included to the outgroup. Scale bar = substitutions per site. Sample abbreviations according to sample ID's from Table S1 and as described in Fig. 2. Support values are ML bootstraps, MP bootstraps, and NJ LogDet bootstraps, respectively. “*” represents $100 \%$ support, whereas “_" $=<0.95$ posterior probability or $<70 \%$ bootstrap support.

Fig. S 2.5 ML tree without outgroup and rooted on L. nigrescens (B859) 96

Fig. S 2.6 Node age differences between root positions and calibration strategies. Notice that the y-axis for the root height is different to the y-axis for the ingroup node heights. Graphic showes that the node heights within Australasia are nearly independent from the root position (exept for root $\mathrm{C}$ cal-C) but vary if a different calibration strategy is used. Solid line root A, dotted line rootB, dashed line root $\mathrm{C}$. Blue calibration strategy $\mathrm{A}$, brown calibration strategy B, black calibration strategy C. 


\section{List of Tables}

Table 1.1 Morphological, anatomical and habitat characteristics of nine Lessonia species including their synonyms and misapplied names.

Table 1.2 Taxonomic changes of the Laminariales over time. 38

Table 2.1 Marker and dataset characteristic (matrix-I). Table shows the length of the marker regions, the mixture of variability in the markers used (variable sites (v) and parsimony informative sites (p.i.) in ingroup comparison), and amount of saturation (including outgroup). $\mathrm{mt}=$ mitochondrial, $\mathrm{cl}=$ chloroplast, nuc $=$ nuclear, $\mathrm{bp}=$ base pair. ${ }^{1}$ Test of variability after Koblmueller et al. 2006 (<10\% low, $10-20 \%$ high, $>20 \%$ hyper). ${ }^{2}$ Saturation test after Verbruggen \& Theriot 2008 (see also Fig. S 2.2a-g). ${ }^{3}$ for p.i. only. 80

Table 3.1 Sample sites with coordinates (Lat. And Long.) and number (N) of atp8-sp and rbc-sp haplotypes $(\mathrm{H})$, respectively. $\mathrm{X}$ in $\mathrm{LtX}$ indicates that the concrete L. tholiformis haplotype is not known, due to insufficient resolution with SSCP. 146

Table 3.2 Dataset characteristics; showing the number of individuals $(\mathrm{N})$, the length of the marker region and number of variable sites; A) atp8-sp and B) rbcsp. ${ }^{1}$ variable sites of the last $40 \mathrm{bp}$ of the atp8-gene; ${ }^{2}$ variable sites of the first $17 \mathrm{bp}$ of the trnS-gene.

Table 4.1 Primer sequences, and characteristics of ten microsatellite loci from $L$. variegata/W. The values for the PCR profiles are the times in seconds, spent denaturing at $94^{\circ} \mathrm{C} /$ annealing at a designated temperature/extension at $72^{\circ} \mathrm{C}$. Each PCR profile started with an initial denaturation step of $5 \mathrm{~min}$ 
(10min for 33D) at $94^{\circ} \mathrm{C}$ and ended with an extension period of $10 \mathrm{~min}$ at $72^{\circ} \mathrm{C}$. One of each paired primers was dyed with FAM, VIC, PET, HEX, or NED for genotyping. 167

Table 4.2 Number and size range of alleles per locus combined over three populations $\left(\mathrm{N}_{\mathrm{A} / \mathrm{L}}\right)$, populations, sample size $(\mathrm{N})$, number of alleles per population $\left(\mathrm{N}_{\mathrm{A}}\right)$, observed $\left(\mathrm{H}_{\mathrm{O}}\right)$ and expected $\left(\mathrm{H}_{\mathrm{E}}\right)$ heterozygosity. * significant deviation from $\mathrm{HWE}$ at $\alpha=0.05 ; \mathrm{nv}=$ not variable; N/A marker needs optimisation 169

Table 4.3 Amplification success and allele region for three additional Lessonia variegata lineages (sample size one) in comparison with L. variegata/W (sample size as in Table 4.2). Lineage abbreviations as in Chapter 2, $\mathrm{K}$ Kaikoura lineage, N northern lineage, S southern lineage, W Wellington lineage.

Table 5.1 Sample size $(\mathrm{N})$, number of alleles per locus and population $\left(\mathrm{N}_{\mathrm{A}}\right)$, observed $\left(\mathrm{H}_{\mathrm{O}}\right)$ and expected $\left(\mathrm{H}_{\mathrm{E}}\right)$ heterozygosity. * significant deviation from HWE at $\alpha=0.05$ (after sequential Bonferroni correction); $\mathrm{nv}=$ not variable. 203

Table 5.2 First series of AMOVA tests exploring variation within dataset. Groupings of locations are given in brackets. Highest $\mathrm{F}_{\mathrm{CT} / \mathrm{SC}}$ was found in Test No. 6 . Fi, Fighting Bay; Te, Cape Terawhiti; Mo, Moa Point; Tu, Turakirae Head; Pa, Cape Palliser; Ma, Mataikona; SS, Sum of squares; *, p<0.05; **, $\mathrm{P}<0.001 ; * * *, \mathrm{p}<0.0001 ;{ }^{\mathrm{ns}}$, not significant. .204

Table 5.3 Pairwise $\mathrm{R}_{\mathrm{ST}}$. Names with numbers indicate the specific sample sites. Red font: significant values after sequential Bonferroni correction $(\mathrm{p}<0.05)$. Insert: 2-sited t-test evaluating the strength and significance of the breaks 
found. The t-test was used to compare the within groups variation to the between groups variation; groups are coded as square brackets. ${ }^{* * *}$, p<0.0001. Fight, Fighting Bay; Tera, Cape Terawhiti; Moa, Moa Point; Tura, Turakirae Head; Pall, Cape Palliser; Mata, Mataikona 205

Table 6.1 Affiliation of the South American species (L. flavicans, L. ovata, $L$. nigrescens, and L. trabeculata) to selected authorities and their understanding of the species. L. flavicans has been confused with $L$. fuscescens, L. nigrescens, $L$. frutescens, $L$. nigrescens $f$. lacunifera, and $L$. vadosa; whereas, L. ovata has been confused with L. fuscescens, $L$. flavicans, L. frutescens, and L. searlesiana. N, number of species recognised on the Falkland Islands (species recognised on the Falkland Islands have a grey background); the first three letters of the name have been used for species and genera (if not Lessonia) abbreviation; na, not applicable; nm, not mentioned.

Table 7.1 Lessonia haplotypes from GenBank. Sp., species affiliation according to this Chapter; det., determined (species affiliation in GenBank according to the Author). L.fla, L. flavicans; L.ova, L. ovata; L.vad, L. vadosa; atp8, spacer region between atp-dehydrogenase subunit 8 and t-RNA serine; trnW-sp, the spacer between the t-RNA's for tryptophan and isoleucine; nd6, a partial sequence of the gene coding for NADH dehydrogenase subunit 6 ; rbc, spacer between the large and short subunit of the ribulose1;5-bisphosphate carboxylase/oxygenase gene; ITS, nuclear marker covering the internal transcribed spacers (1 and 2) between the large and small-ribosomal RNA subunits; and the 5.8S ribosomal RNA; gb, GenBank accession number; code, haplotype in the network. .258 
xxiv

Table 7.2 Morphological characteristics and habitat of $L$. variegata lineages (tentative)

\section{Supplementary Tables}

Table S 2.1 Species identification, sample ID, location with geographic information (if available), and GenBank accession numbers. Collector if not authors in parentheses. indicates that exact GPS location of the sampled population was not recorded but retrieved from Google Earth ver. 5.1. The L. flavicans specimen (A635) was also used in a previous study by Lane et al. (2006); however I suspect it to be misidentified L. vadosa

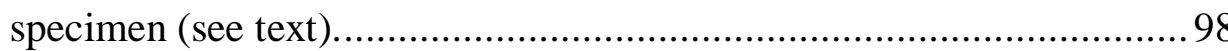

Table S 2.2 Primer characteristics and their coded PCR-profiles (see Fig. S1).

Primers in bold were developed for this study. The original primer was put in brackets if only slight modifications were made. ${ }^{a}$ after Voisin et al. 2005; ${ }^{\mathrm{b}}$ after Lane at al. 2006; ${ }^{\mathrm{c}}$ after Peters \& Ramirez 2001; ${ }^{\mathrm{d}}$ after Tai et al. 2001 105

Table S 2.3 Partition-homogeneity test or Incongruence Length Test (PAUP*) with heuristic search (nreps=100; TBR). A test to verify whether different datasets can be combined into a supermatrix. Cunningham (1997) suggested that $\mathrm{p}$-values $>0.01$ indicate that combining the data will generally improve the accuracy of the phylogeny. If p-values are $<0.001$ the accuracy of the combined data would suffer relative to the individual 
partitions. The combination of the marker datasets into a supermatrix (matrix-I) is favoured. 106

Table S 2.4 Partition strategy test (Tracer v1.5). BF > 20 is strong support for favoured model. Nst=6 Rates=invgamma ngammacat $=8$ [was applied separately for all partitions]. The partition of the supermatrix by marker regions and in case of the nd6-gene additionally by codon position is favoured.

Table S 2.5 HKY-distances (matrix-I) between and within lineages (PAUP*). F = Falkland Is, IA = intermediate area, $\mathrm{K}=$ Kaikoura, $\mathrm{N}=$ northern, $\mathrm{P}=$ Patagonia, $\mathrm{S}=$ southern, $\mathrm{sc}=$ species complex, $\mathrm{W}=$ Wellington. Table S5a. Ingroup comparison. Table S5b. Outgroup comparison 108

Table S 2.6 Molecular clock test (PAUP*). T1 = without clock; T2 =clock enforced. $\mathrm{AA}=$ Australasia, $\mathrm{SA}=$ South America. Molecular clock was rejected for all Lessonia but accepted for tests within geographic groups $(\mathrm{p}=0.001)$. Bonferroni was not applied as the $\mathrm{p}$-values depent on the topology. For the root position see Table S 2.7

Table S 2.7 Topology test (Paired Sites Tests in treefinder version of October 2008). No topology is rejected, but TopoA has the best support.

Table S 2.8 Average difference in GC-content (matrix-I)

Table S 5.1 Estimated null allele frequencies for all loci in a population using Brookfield 1 and Bonferroni corrections. Null alleles are evident in Fighting Bay, Turakirae Head, and Mataikona, however, no evidence for null alleles was found in GWG or CSC. Bottom row shows the number (in brackets) of homozygotes to be corrected $\left(\mathrm{H}_{\mathrm{C}}\right) .{ }^{*}$, indicates significant null allele frequencies. Fight, Fighting Bay, Tera, Cape 
Terawhiti, Moa, Moa Point, Tura, Turakirae Head, Pall, Cape Palliser, Mata, Mataikona, GWG, Greater Wellington Group (Cape Terawhiti, Moa Point, and Turakirae Head), CSC, Cook Strait Cluster (Fighting Bay and Greater Wellington Group). 207

Table S 5.2 Linkage disequilibrium test conducted against 1,000 permutations in ARLEQUIN. *, $\mathrm{p}<0.05$ (after sequential Bonferroni correction) 208

Table S 5.3 Allele frequencies and private alleles (red) for all populations by locus. $\mathrm{N}_{\mathrm{A}}$, number of alleles; $\mathrm{N}_{\mathrm{PA}}$, number of private alleles; Fight, Fighting Bay; Tera, Cape Terawhiti, Moa, Moa Point; Tura, Turakirae Head; Pall, Cape Palliser; Mata, Mataikona. 209

Table S 5.4 Second series of AMOVA tests exploring variation within clusters and groups. Groupings are given in brackets. A) The best grouping within the Cook Strait Cluster was found with $[\mathrm{Fi}][\mathrm{Te} / \mathrm{Mo} / \mathrm{Tu}]$ (test No. $5 ; \mathrm{F}_{\mathrm{CT} / \mathrm{SC}}=$ 24.7). B) No significant variation was found within Grater Wellington group. C) $\mathrm{F}_{\mathrm{ST}}$ between Cape Palliser and Mataikona is significant but $\mathrm{F}_{\mathrm{IS}}$ is not indicating differentiation between Cape Palliser and Mataikona with no subsequent structure in either of these groups. Fi, Fighting Bay; Te, Cape Terawhiti; Mo, Moa Point; Tu, Turakirae Head; SS, Sum of squares; $*, p<0.05 ; * *, p<0.001 ; * * *, p<0.0001 ;{ }^{\text {ns }}$, not significant.... 211

Table S 5.5 Third series of AMOVA tests exploring variation among and within sites. No significant values were found. SS, Sum of squares; ${ }^{\text {ns }}$, not significant 


\section{Chapter 1 \\ Introduction \& overview}

\subsection{Thesis structure}

For this thesis I studied the phylogeny of the genus Lessonia, the phylogeography of Australasian Lessonia species, and the connectivity of populations using Cook Strait as a case study area. The approaches are hierarchical so that the results of one topic serve as the basis for the next. Experience has shown that phylogenetic methods improve if the phylogeny of the next highest level is known (e.g., for the choice of the outgroup). Also when local genetic patterns have to be interpreted it is helpful to know whether they derive from a monophyletic grouping or not. Therefore this dissertation is not only divided into three taxonomic levels for the main data chapters but also chronologically ordered into themes that allowed me to go from global to local while using information gained at higher levels.

Lessonia is introduced in Chapter 1, starting with reviewing early and recent descriptions and the known biogeography of Lessonia as the conceptional framework of this study (Section 1.2); this is followed by explaining the biology of Lessonia with a focus on its dispersal abilities based on different phases of its heteromorphic life cycle as a background for diverse dispersal scenarios (Section 1.3). Before I started, a taxonomic reorganisation at the family level (Lane et al. 2006), fundamentally changed our knowledge of sister taxa to Lessonia. The genera Eisenia, Ecklonia and Egregia form now, together with Lessonia, the family 
Lessoniaceae and are considered the primary source for outgroups (Chapter 1.4). In Chapter 2 I report on the global phylogeny of Lessonia investigating almost all known Lessonia species using molecular markers from mitochondrial, chloroplast, and nuclear DNA. In this study I first recognised four cryptic species within Lessonia variegata. Also new is the discovery of a monophyletic Australasian group, comprising the species endemic to New Zealand (L. variegata, L. brevifolia, $L$. adamsiae, L. tholiformis) and Tasmania (L. corrugata). This Australasian group is investigated more closely in Chapter 3 using the mitochondrial atp8-spacer region and a method (SSCP) for fast and cost-efficient screening of a large dataset. The distribution of all Australasian species is mapped and compared to known biogeographic and phylogeographic breaks. Chapter 4 is written as a technical note to introduce new microsatellite markers that I developed specifically for Lessonia to address questions on a finer local scale. This is finally done in Chapter 5 where the Cook Strait seaway is tested for its influence on the connectivity of populations. In Chapter 6, I address a nomenclatural problem that persisted for the southern South American Lessonia species, which had led to a multiplication of names and taxonomic confusion. Chapter 7 provides a summary and outlines directions for future research.

All data Chapters (Chapter 2 to 5) are written in a style to be submitted to a scientific journal for publication.

-Chapter 1: Introduction and overview

-Chapter 2: Martin, P., \& Zuccarello, G, C,. Molecular phylogeny and timing of radiation in Lessonia (Phaeophyceae, Laminariales). Journal of Phycology. (submitted) 
-Chapter 3: Phylogeography of Lessonia (Phaeophyceae, Laminariales) in Australasia

-Chapter 4: Characterisation of microsatellites in the Southern Hemisphere kelp, Lessonia variegata (Phaeophyceae, Laminariales)

-Chapter 5: Connectivity between populations of Lessonia variegata

(Phaeophyceae, Laminariales) across Cook Strait, New Zealand

-Chapter 6: Taxonomic confusion in Lessonia from the Falkland Islands

-Chapter 7: Summary and directions for future research 


\subsection{Lessonia - First descriptions and biogeography}

Lessonia Bory, 1825:p.23 as Lessonia flavicans. Caule subarboreo cylindrico, ramis compressis, foliis ovato-linearibus, subdenticulatis flavicantibus. [Species description also validating the genus (ICBN Art. 42)]

Lessonia is a member of the family Lessoniaceae Setchell \& Gardner 1925:591 within the order Laminariales Migula 1909:243. The genus Lessonia was never formally described but the description of the single species of Lessonia flavicans (see above) also validated the genus (Art. 42 ICBN, Searles 1978). An emended description of Lessonia is: "Thallus 1-4 m high, perennial. Holdfast discoid, divided and becoming conical, or ligulate, attached by branched haptera, with the stipe branched from the base or higher, often twisted, with each branch bearing a blade. Blades simple, 0.5-2 $\mathrm{m}$ long and 1-5 $\mathrm{cm}$ wide, ligulate to irregularly elongate, flat, margins denticulate, surface smooth to rugose or corrugate. Growth by longitudinal splitting of the blades, resulting in dichotomous branching of stipe. Blade and stipe with a central, filamentous medulla, extensive cortex of relatively small cells with or without mucilage cavities, and outer layer of meristoderm. Spores produced in unilocular sporangia with paraphyses in extensive sori, produced on both surfaces of blades. Gametophytes dimorphic, dioecious, oogamous, branched uniseriate filaments" (Guiry \& Guiry 2011).

Currently nine species are recognized within Lessonia (Table 1.1), however, the species have been often confused with each other in the literature because of misleading and entangled descriptions and different interpretations of the original 
diagnoses. The latest attempt to clarify the situation has been made by Asensi \& de Reviers (2009) who created an illustrated catalogue of type species preserved at the Muséum National d'Histoire Naturelle, Paris, France (PC). Their main changes have been a new lectotypification of $L$. flavicans and the description of a new species $L$. searlesiana based on herbarium material. In the following I will introduce all known Lessonia species, their synonyms and distribution while a critical review of the works of Lessonia authorities and others that have influenced our knowledge about this genus will be given in Chapter 6.

Lessonia is the only genus of the Laminariales that is solely distributed in the Southern Hemisphere (Bolton 2010) between $12^{\circ} \mathrm{S}$ and $56^{\circ} \mathrm{S}$. Four species are currently recognised in South America, five in Australasia, and two unknown species are reported from the Kerguelen and Heard Islands (Hay 1987, Edding et al. 1994). The South American species are Lessonia flavicans Bory 1825, L. nigrescens Bory 1826, L. ovata Hook.f.\&Harv., 1847, and L. trabeculata Villouta \& Santelices 1986 [but see also Searles (1978) for species recognition before 2009 and Asensi \& de Reviers (2009) for a revision on species nomenclature of L. flavicans and L. vadosa; here I adopt the suggestions made by Asensi \& de Reviers (2009) but with $L$. searlesiana as a synonym to the earlier described L. ovata]). In Australasia we recognise L. variegata J. Agardh 1894, L. brevifolia J. Agardh 1894, L. corrugata Lucas 1931, L. adamsiae Hay 1987, and L. tholiformis Hay 1989. Species reported from Kerguelen and Heard Islands are L. nigrescens and L. ovata on Heard (Dickie 1876), L. flavicans (as L. fuscescens) on Kerguelen (Dickie 1876 \& 1879), Delepine (1963) reported that there are maybe two species of Lessonia on Kerguelen, and Papenfuss (1964) reported L. fuscescens and L. nigrescens on Heard and L. 
fuscescens on Kerguelen. Even though the species on Kerguelen and Heard Islands are reported as L. nigrescens, L. ovata or L. fuscescens it is more likely that these are undescribed species as Lessonia is a poor disperser (Faugeron et al. 2005) and thus species ranges are restricted. That Lessonia is believed to be a poor disperser is in relation to the seaweeds that have floating structures. Dispersal of spore aggregates, parts of fronts, or detached algae have been shown (in other algae by e.g., Norton 1992 and Sliwa et al. 2006) to be not efficient for long distance dispersal. Lessonia does not have any special floating abilities or other abilities for long distance dispersal and would thus appear to be a poor disperser. However, specimens that are attached to other vehicles might be able to travel long distances. Other vehicles might be other algae that are known for long distance dispersal, for example Macrocystis and Durvillaea antarctica. Both algae grow in close distance to Lessonia and it is known that they can grow on top of each others holdfast (especially Durvillaea antarctica has been found to grow on top of other algae as shown in Fig. 1.11).

The distribution range of the South American species is more or less overlapping, with the intertidal L. nigrescens occupying the widest range from $12^{\circ} \mathrm{S}$ in Peru (Martinez, 1999), around Cape Horn with the Diego Ramirez Islands at $56^{\circ} \mathrm{S}$ as the southernmost record (Kuehnemann1970 in Edding et al., 1994), to Punta Atlas in Argentina (Barrales \& Lobban, 1975) (Fig. 1.1). The northern distribution limit in the Pacific is highly dependent on environmental disturbances such as El Niño, which can result in a disappearance of Lessonia populations as far south as $26^{\circ} \mathrm{S}$, as occurred after the 1982-83 El Nino event (Edding et al., 1994). The wipe-out effect due to high temperature is buffered in areas of coastal upwelling and is not as 
significant for the subtidal L. trabeculata. A recent survey on L. nigrescens populations from Chiloe $\left(\sim 42^{\circ} \mathrm{S}\right)$ to the north of its distribution range revealed the existence of two genetically distinct cryptic species (Tellier et al. 2009). Unfortunately no L. nigrescens was included from its type locality (Cape Horn) thus it is unsure whether all genetic variation is covered. If L. nigrescens from the type locality differs from the IA-lineage (intermediate area lineage as used by Tellier et al. 2009) to an extent normally found between species, then L. berteroana Montagne, 1842 could be resurrected from its synonymous status with L. nigrescens into a valid species status. L. berteroana has narrower, acute blades (not as wide as in L. nigrescens), a filamentous cortex with clusters of ramified filaments (rather than a homogenous cortex), elongated epidermal cells, and a more northern distribution (Asensi \& de Reviers 2009). As the type locality of L. berteroana lays in the Z30 zone (see Tellier et al. 2009) it belongs most likely to either the Z30 or IAlineage but not the northern lineage, which has to be described. Further investigations are needed to clarify and describe the status of species within this complex.

The subtidal L. trabeculata shares its range with the intertidal L. nigrescens on the Pacific coast of South America from as far north as $14^{\circ} \mathrm{S}$ (Fernandez, 1999), and south to $42^{\circ} \mathrm{S}$ (Villouta \& Santelices, 1986) (Fig. $1.1 \& 1.2$ ). Variation in the size of populations from the northern range of $L$. trabeculata can occur in La Niña years, when grazer abundance is strongly increased (Vega et al., 2005).

The southernmost distribution of L. flavicans is the Beagle Channel from where it is found north until $49^{\circ} \mathrm{S}$ on the Chilean coast and to $47^{\circ} 44^{\prime} \mathrm{S}$ (Puerto 
Deseado) on the Argentinian coast, and east to the Falkland Islands (Searles, 1978) (Fig. 1.3).

L. ovata shares its north-eastern (Puerto Deseado, Argentina), eastern (Falkland Islands) and northwestern (Canal Trinidad) limit with L. flavicans, but is found further south all around Cape Horn (Searles, 1978) (Fig. 1.3). L. ovata might occure in two different morphotypes (Fig. 1.6).

In southern Chile L. nigrescens co-occurs with L. flavicans and L. ovata (Fig. 1.4), however, L. nigrescens is absent from the Falkland Islands (Fig. 1.5).

Skottsberg's $(1907,1921)$ reports of L. nigrescens on the Falkland Islands are misleading as his concept of L. nigrescens was synonymous to L. vadosa (Chapter 6). Searles (1978) excluded the records of L. nigrescens from the Falkland Island (Hooker \& Harvey 1845, p.152 [wrong citation in Searles 1978; should be Hooker \& Harvey 1847, p.458]; Skottsberg 1907, p.72; and Cotton 1915, p.166), indicating misidentification in all cases. The affiliation of species in South America seems to be difficult because of overlapping species ranges in synchrony with overlapping morphologies and the occurrence of probably two ore more undescribed species (Searles, 1978; Ramirez and Santelices, 1991). The intertidal habitat, occupied in South America by L.nigrescens, might be occupied on the Falkland Islands by a morphotype of L. flavicans (Fig. 1.7A); whereas two additional morphotypes might occure in the subtidal habitat (Fig. $1.5 \& 1.7 \mathrm{~B}-\mathrm{F}$ ).

In contrast to the overlapping distribution of the South American Lessonia (Fig. 1.1-5) the distribution of Lessonia in Australasia is localized and shows high endemism (Fig. $1.8 \& 1.9$ ). 
Lesssonia corrugata is endemic to Tasmania (Australia), L. variegata to the three main Islands of New Zealand (North Is, South Is, and Stewart Is), $L$. tholiformis to the Chatham Islands, L. adamsiae to the Snares, and L. brevifolia to the four Sub-Antarctic Islands of New Zealand (Auckland Islands, Campbell Islands, Antipodes Islands, and Bounty Islands). However, Schiel and Hay observed dense clumps of presumably L. brevifolia at a site at Five Fingers Peninsula (Fiordland; South Is.) where otherwise L. variegata was dominant (Schiel \& Hickford, 2001). This is the only record of co-occurrence in Lessonia sp. in Australasia.

\subsubsection{Distinguishing features of Lessonia species and their synonyms}

\subsubsection{Australasian species}

Lessonia adamsiae Hay, 1986:295ff endemic to The Snares was named after Nancy Adams, a well known New Zealand phycologist, and is different to other species by conspicuously corrugated blades (which look similar to the corrugation found in Macrocystis and differ markedly from the corrugation associated with L. corrugata) and a high number of predominantly flattened branches (up to 100) that emerge from the holdfast. The base is a massive, asymmetrical coalescence of holdfast, basal branches and haptera, which is otherwise only known from L. trabeculata.

Lessonia brevifolia J. Agardh, 1894:88 was described from the Auckland Island as being a dwarf species that is scarcely one foot $(30 \mathrm{~cm})$ long. In the diagnosis Agardh (1894) states that the length of the blades are scarcely four times longer than their breadth. In the narrative he mentioned a length of $4-5$ inches $(10-13 \mathrm{~cm})$ and that all blades show an erose apex structure and that no "fruit-bearing" sori have been seen. As the blades of this species develop normal length comparable with $L$. variegata (per. obs.) it is speculative that the specimen Agardh based his description 
on had lost the upper part of the blade below the sori, which would give them the appearance of a short bladed form. L. brevifolia differs from other Australasian Lessonia by the small number of branches that emerge from the base (1-2(4)) and a more or less hapteroid holdfast of mainly unfused and freely branching haptera (Hay 1987). The species is now known from the Auckland Islands, Campbell Islands, Bounty Islands, and Antipodes Islands (Hay 1987, Adams 1994) where it might be found to a depth of 30m (Hay et al. 1985).

Lessonia corrugata Lucas, 1931:410 is endemic to Tasmania and easy to distinguish by its corrugated blades. It is the only Australasian species that is not found in New Zealand.

Lessonia tholiformis Hay, 1989:461ff is only known from the Chatham Islands. Young individuals might have corrugated leaves like L. adamsiae but the species is easy to distinguish from other Lessonia by its unique dome-shaped holdfast (hence tholiformis=form of a tholus $\{$ in ancient Greek architecture, a circular building with a conical roof $\}$ ).

Lessonia variegata J. Agardh, 1877:6 was first mentioned by J. Agardh while listing the marine algae of New Zealand. He only mentioned that L. variegata had lacunae and did not provide any other diagnosis of this species; this however was done by Laing (1894) who validated J. Agardh as the authority. L. variegata is found in the subtidal to a depth of $18 \mathrm{~m}$ (Schiel 1990) in exposed rocky shores of the North Island, South Island, and Steward Island (Hay 1987, Adams 1994). Cryptic speciation within a $L$. variegata species complex was recently detected (Chapter 2) with a unique distribution of each of the four lineages (Chapter 3). The type locality is Wellington (Lyall Bay), where it has striated blades (thus variegata). 
No synonyms are known for any Australasian Lessonia but they have been listed as L. fuscescens (Hooker 1867, Dickie 1879), L. flavicans (Papenfuss 1964, Hay et al. 1985), or L. variegata on the Sub-Antarctic Islands (Papenfuss 1964, Hay et al. 1985) before they were described as distinct species.

\subsubsection{South American species}

Lessonia flavicans Bory, 1825:23 was the first Lessonia species described; successive descriptions made by Bory de Saint-Vincent in 1825, 1826 and 1828 of the same species but with different epithets (which all translate to yellowish) has led to confusion about its affiliation (see Chapter 6) and until recently a different species was associated with this name (i.e., the species definition after Searles (1978) was generally accepted). The old and new understanding of L. flavicans is of a big, treelike alga with narrow blades and less wide blade base angle compared to L. ovata or L. searlesiana and with cortical lacunae in blade sections. The species is found at some distance from the shore and, when fully grown, it might have only one stem. Its appearance is as depicted in the 'Atlas' of the 'Voyage autour du monde' (Bory de Saint-Vincent 1828), 'Flora Antarctica' (Hooker \& Harvey 1847) and 'Illustrationes algarum' (Postels \& Ruprecht 1840). [This description does not entirely conform with the description made by Asensi \& de Reviers (2009) but it is conform to the first descriptions made by d'Urville and Bory de Saint-Vincent in 1825,1826 and 1828; it is also conform to the new lectotype of L. flavicans and to a species found at the Falkland Islands.) Synonymy: Lessonia fuscescens Bory, 1826; Lessonia frutescens Skottsberg, 1907; Lessonia nigrescens f. lacunifera Skottsberg, 1921; Lessonia vadosa Searles, 1978; Misapplied names: L. nigrescens sensu Skottsberg 
Lessonia nigrescens Bory, 1826:322, should be regarded as a species complex with at least two cryptic species (Tellier et al. 2009). It has an easy to identify and unique holdfast with tightly fused haptera to build a hemispherical mound where up to 20 branches protrude. Branches and blades have a dark colour (therefore nigrescens). L. nigrescens is the only Lessonia species to be found in the intertidal. Synonyms: Laminaria ramosissima Lamour. \& Chauv. (nomen herbariorum ? in Bory de Saint-Vincent 1825); Chordaria spicata Suhr, 1839; Laminaria scissa Suhr, 1841; Lessonia suhrii J. Agardh, 1841 [nom. illeg. Art. 55 ICBN]; Lessonia berteroana Mont., 1842; Lessonia binderi Sonder (nom. herb. ? in Kuetzing 1849); Lessonia nigrescens f. montagnei Skottsberg, 1921.

Lessonia ovata Hook.f.\&Harv. 1847:459 has short dichotomously branched stipes with short branches, which are further divided; the petiole broadens into an ovate or linear-ovate, olive to darkish green, thin-skinned lamina. The lamina are often very broad $(6-40 \mathrm{~cm})$, which gives the blade an oval (ovata) shaped base. Blade base angle is broader than in L. flavicans. No lacunae are present in stipe or blade. Synonyms: Lessonia searlesiana Asensi \& de Reviers, 2009 Misapplied names: Lessonia frutescens sensu Searles.

Lessonia searlesiana Asensi \& de Reviers, 2009:209ff is most likely a synonym of $L$. ovata, see this entry and Chapter 6.

Lessonia trabeculata Villouta \& Santelices, 1986:81ff is found subtidally from $0.5-20 \mathrm{~m}$ and shares its distribution range with the intertidal L. nigrescens. It has a massive, asymmetrical and irregularly shaped holdfast where many branches emerge at the base still tightly packed. In transverse sections of the blade, lacunae with elongated, multicellular filaments (trabeculae) are visible under the 
microscope. It was often confused with L. flavicans but as they do not have any overlapping distribution, it is easy to detect.

Taxonomic confusion has been addressed by many authorities of Lessonia (Searles 1978, Villouta \& Santelices 1986, Asensi \& de Reviers 2009), however, no satisfying solution has been found yet and work is still needed. 


\subsubsection{Figures and Tables}
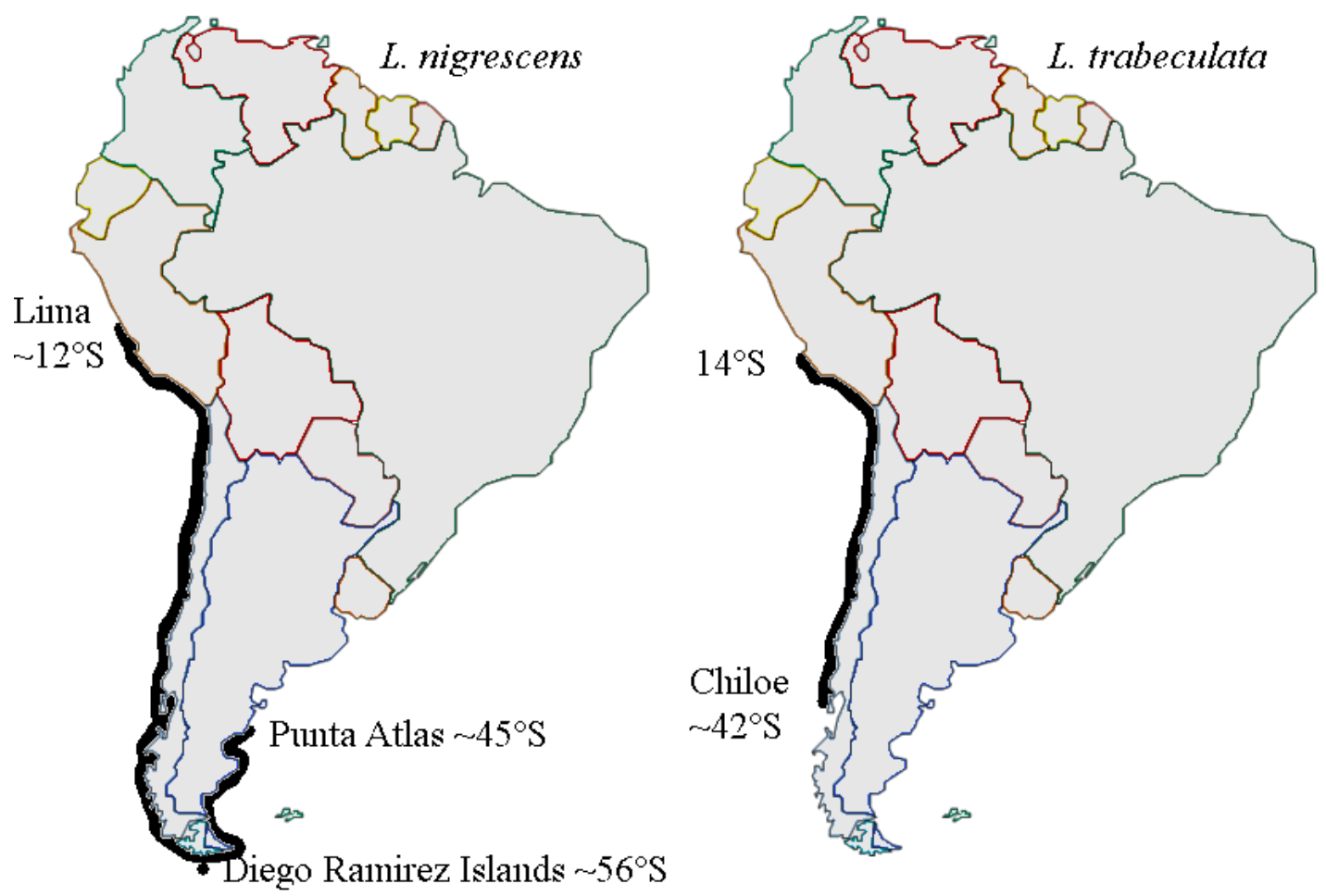

Fig. 1.1 Distribution of L. nigrescens and L. trabeculata.

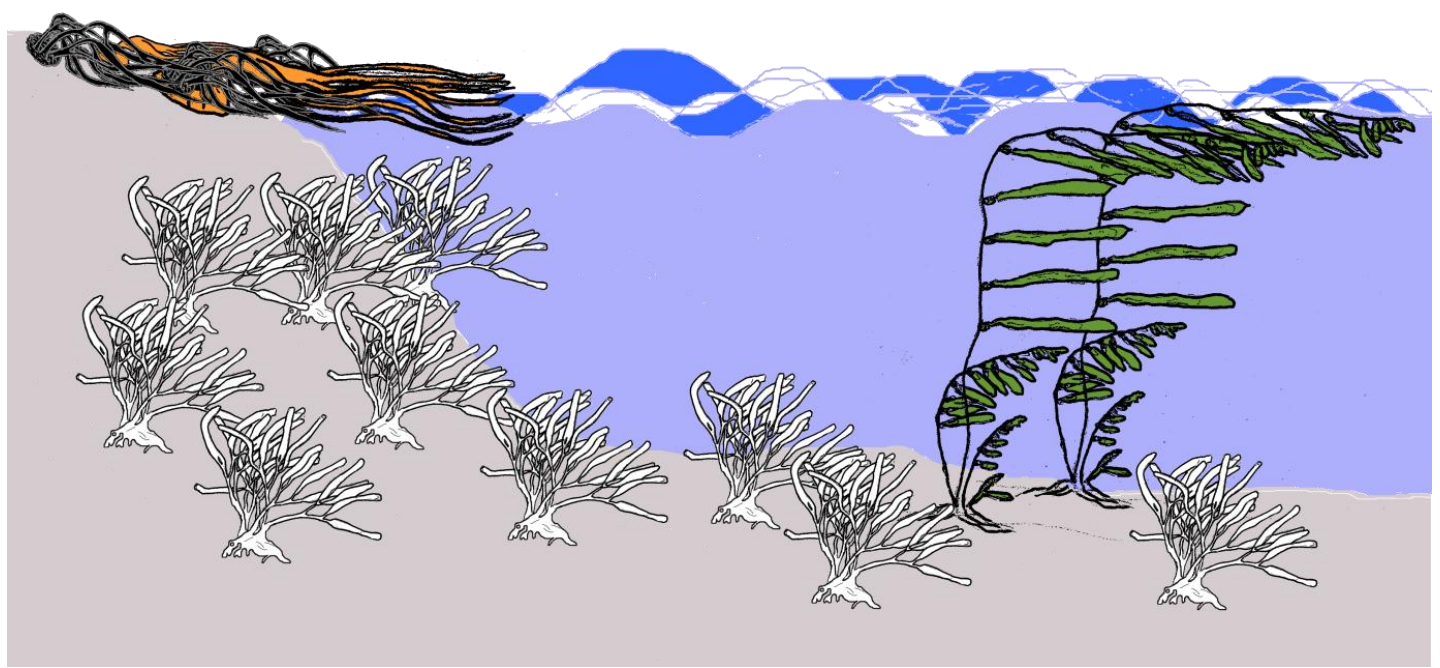

Fig. 1.2 Vertical distribution of Lessonia species in central Chile. L. nigrescens (black) shares the intertidal with Durvillaea antarctica (orange); L. trabeculata (white) is found in the subtidal (0.520m) above and between Macrocystis pyrifera (green). 

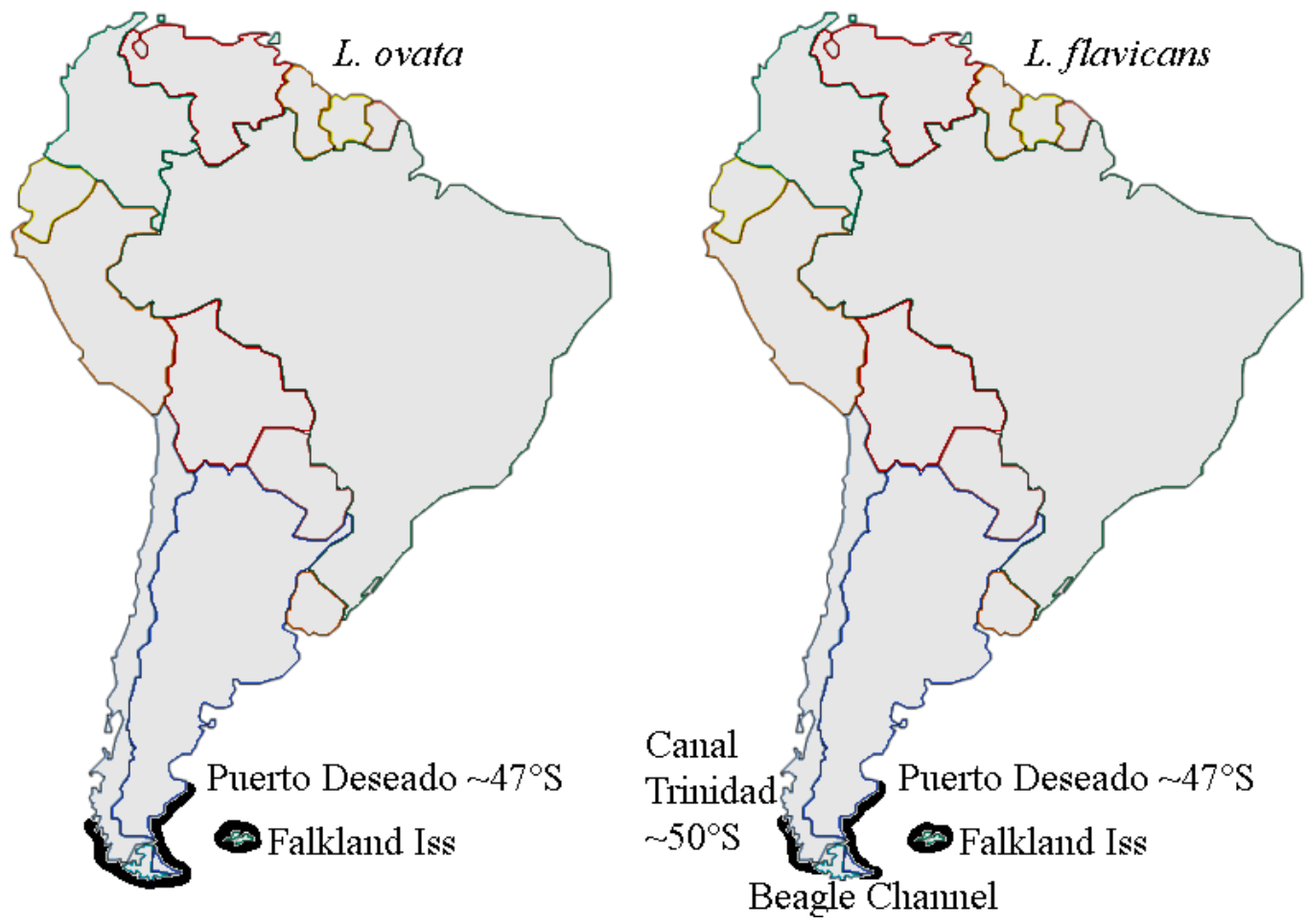

Fig. 1.3 Distribution of $L$. ovata (=L. flavicans sensu Searles) and $L$. flavicans.

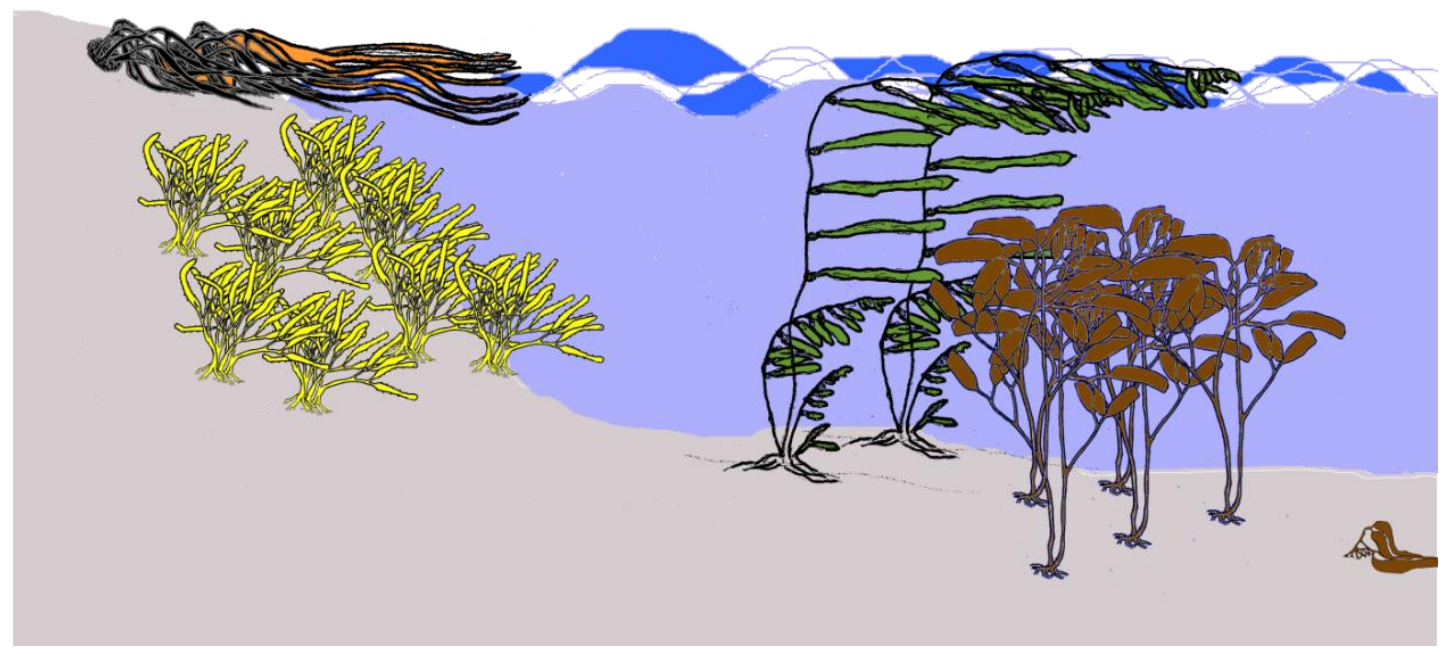

Fig. 1.4 Vertical distribution of Lessonia species in south Chile (Patagonia). L. nigrescens (black)

shares the intertidal with Durvillaea antarctica (orange); L. flavicans (yellow) is found in the subtidal (0.5-2 (15) m) above a belt of Macrocystis pyrifera (green) whereas L. ovata (brown) is found below the Macrocystis belt (2-20). It is possible that L. flavicans might become bigger or as big as L. ovata (see Fig. 1.5 and photographs in Fig. $1.6 \& 1.7$ ). 


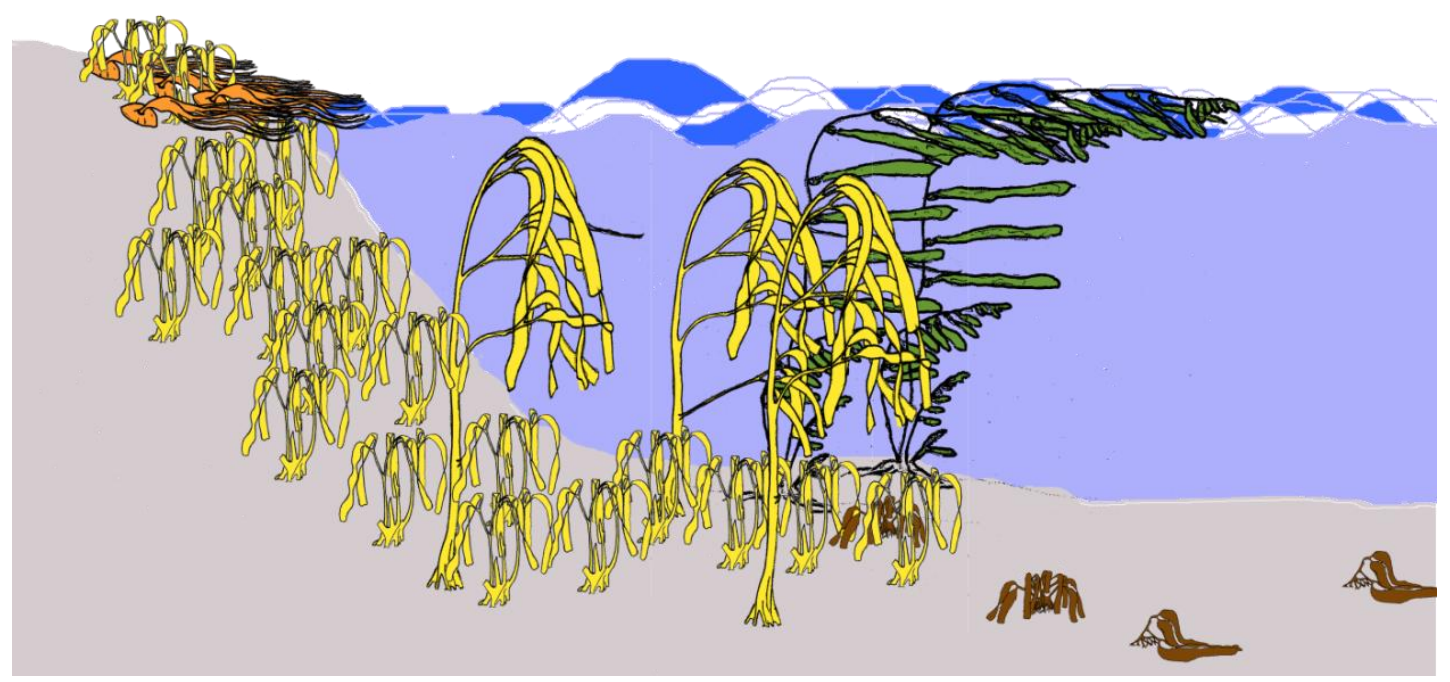

Fig. 1.5 Vertical distribution of Lessonia species at the Falkland Islands. L. flavicans (yellow) can develop into huge algae several meters in height (up to $8 \mathrm{~m}$ with trunks as thick as a human thigh (d'Urville 1825)) and is found in the subtidal (0.5-15m) above and between Macrocystis pyrifera (green) whereas L. ovata (brown) is usually found deeper (?-20) and might develop in big algae $4 \mathrm{~m}$ in height. No L. nigrescens is found at the Falkland Islands but L. flavicans might have extended its range into the intertidal, where it is found between Durvillaea antarctica (orange). In the intertidal $L$. flavicans shows a slightly different morphology with round and more flexible stipes that look similar to the stipes of the intertidal L. nigrescens from the mainland (see photographs in Fig $1.6 \& 1.7$ ). 


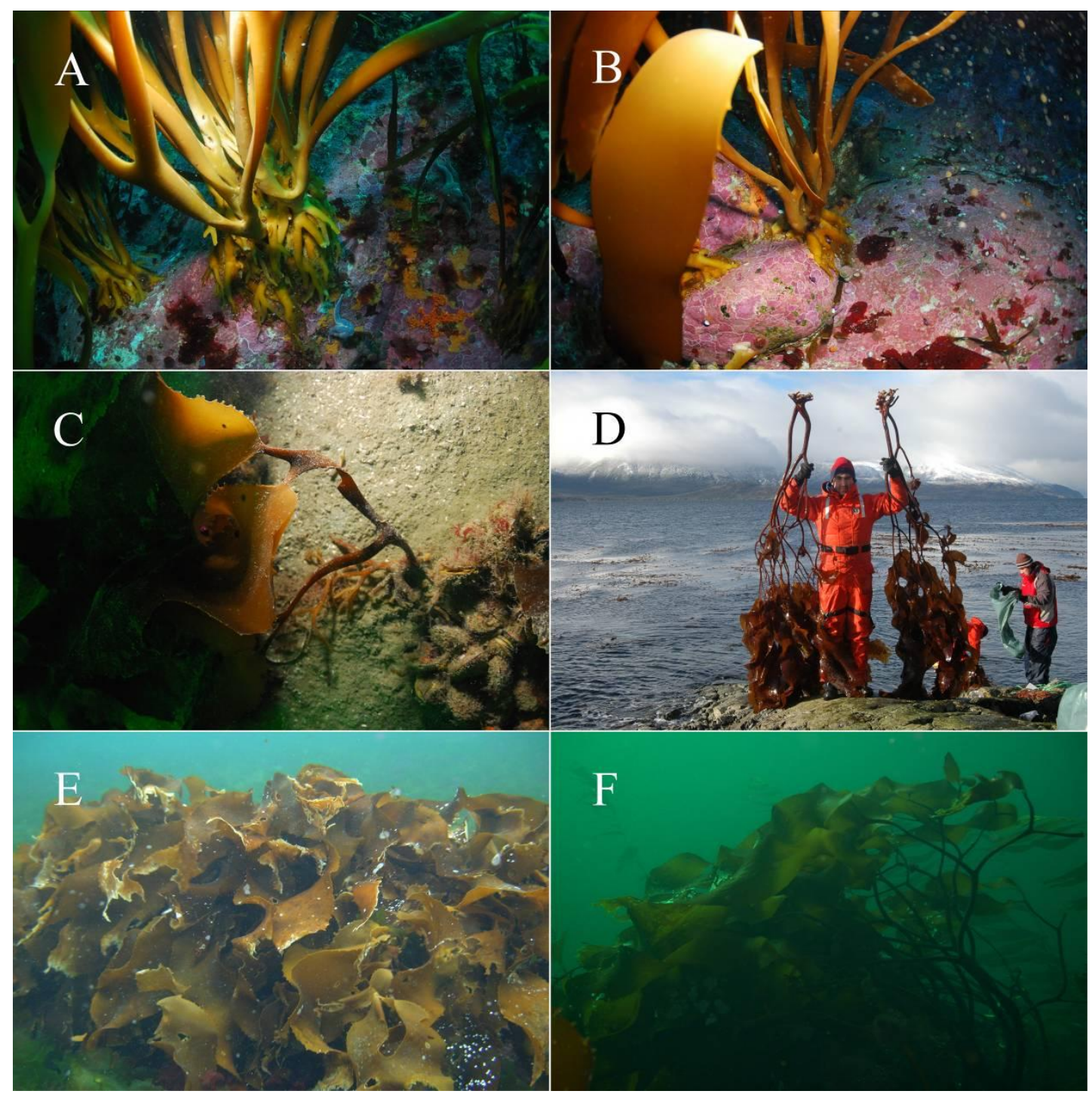

Fig. 1.6 Pictures of Lessonia ovata on the Falkland Islands (A-C) and Patagonia (D-F), showing different morphologies. The pictures on the Falkland Islands were taken at a depth of 20m. (Photos provided by K. Neely (A-C), and C. Cardenas (D-F)). 


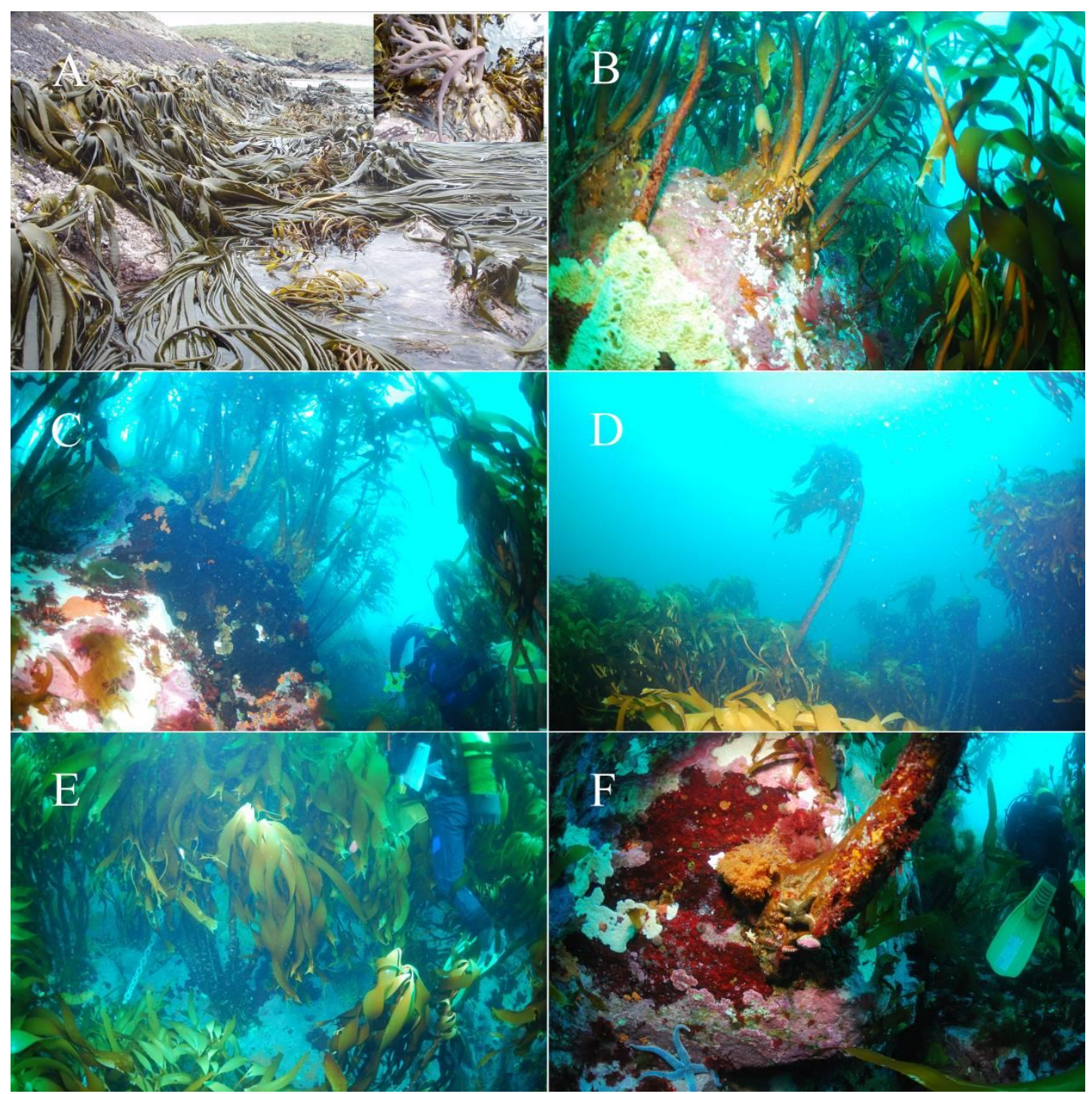

Fig. 1.7 Pictures of Lessonia flavicans on the Falkland Islands, showing different morphologies. A) intertidal together with Durvillaea antarctica. A single intertidal L. flavicans is shown in the insert. Note that even if the stipes appear similar to the stipes of L. nigrescens, the holdfast morphology is different to the one found in L. nigrescens, B-F) subtidal morphologies showing exceptionally big thalli extending above the canopy (D). (Photos taken by C. Fraser (A), or given by K. Neely (B-F)). 


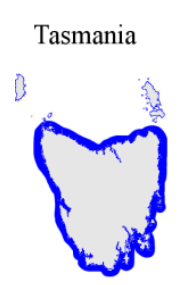

L. corrugata

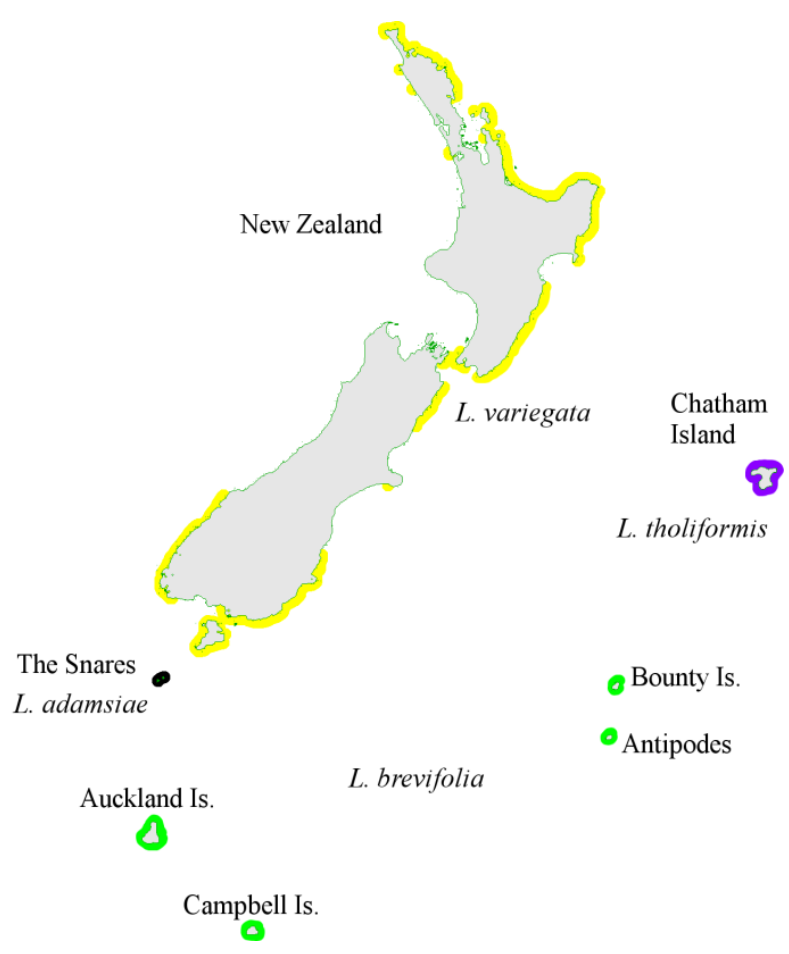

Fig. 1.8 Distribution of Lessonia in Australasia showing restricted distribution with no overlapping species ranges.

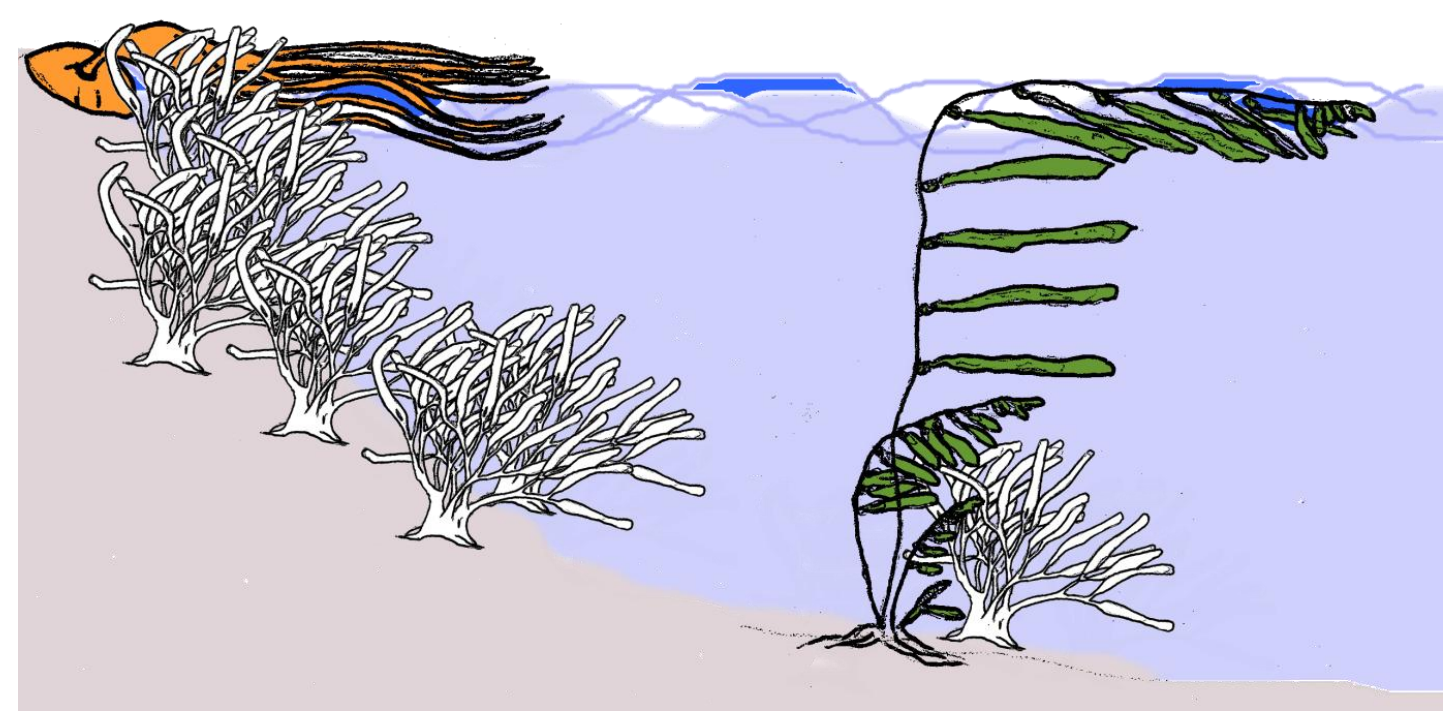

Fig. 1.9 Distribution of Lessonia in Australasia. Lessonia (white) is found in the subtidal below Durvillaea antarctica (orange) till 10-20m, depending on the species. Macrocystis pyrifera (green). 
Table 1.1 Morphological, anatomical and habitat characteristics of nine Lessonia species including their synonyms and misapplied names.

\begin{tabular}{|c|c|c|c|c|c|c|c|c|c|}
\hline Features & L. brevifolia & L. adamsiae & L. tholiformis & L. variegata* & L. corrugata & L. ovata & L. nigrescens* & L. trabeculata & L. flavicans \\
\hline Size & up to $2.5 \mathrm{~m}$ & up to $3 \mathrm{~m}$ & up to $1.5 \mathrm{~m}$ & $1-1.5 \mathrm{~m}$ & $1-1.5 \mathrm{~m}$ & up to $4 \mathrm{~m}$ & up to $4 \mathrm{~m}$ & up to $2.5 \mathrm{~m}$ & $\begin{array}{l}\text { up to } 3 \mathrm{~m} \text { and } \\
\text { more }\end{array}$ \\
\hline Habitat & $\begin{array}{l}\text { subtidal } \\
2-25 \mathrm{~m}\end{array}$ & $\begin{array}{l}\text { subtidal } \\
1-22 \mathrm{~m}+\end{array}$ & $\begin{array}{l}\text { subtidal } \\
>10 \mathrm{~m}\end{array}$ & $\begin{array}{l}\text { subtidal } \\
1-15 \mathrm{~m}\end{array}$ & $\begin{array}{l}\text { subtidal } \\
1-10 \mathrm{~m}\end{array}$ & $\begin{array}{l}\text { subtidal } \\
2-20 \mathrm{~m}\end{array}$ & $\begin{array}{l}\text { intertidal } \\
+1 \text { to }-1 \mathrm{~m}\end{array}$ & $\begin{array}{l}\text { subtidal } \\
0.5-20 \mathrm{~m}\end{array}$ & $\begin{array}{l}\text { shallow } \\
\text { subtidal } \\
0.5-2 \mathrm{~m}(15)\end{array}$ \\
\hline Distribution & \multicolumn{5}{|l|}{ Australasian } & \multicolumn{4}{|c|}{ South American } \\
\hline & $\begin{array}{l}\text { N.Z. Sub- } \\
\text { Antarctic } \\
\text { Islands }\end{array}$ & Snares I., NZ & $\begin{array}{l}\text { Chatham Is., } \\
\text { NZ }\end{array}$ & $\begin{array}{l}\text { N.Z. North } \\
\text { Island, South } \\
\text { Island, } \\
\text { Stewart } \\
\text { Island }\end{array}$ & $\begin{array}{l}\text { Tasmania, } \\
\text { AUS }\end{array}$ & $\begin{array}{l}\text { magellanic } \\
\text { South } \\
\text { America, } \\
\text { southern } \\
\text { Patagonia; } \\
\text { Falkland } \\
\text { Islands }\end{array}$ & $\begin{array}{l}\text { south from } \\
\text { Lima } \\
\left(\text { Peru, } 12^{\circ} \mathrm{S}\right) \\
\text { along the } \\
\text { Chilean coast, } \\
\text { around Cape } \\
\text { Horn } \\
\text { (including } \\
\text { Diego } \\
\text { Ramirez } \\
\text { Islands, } \\
\left.\sim 56^{\circ} \mathrm{S}\right) \text {, till } \\
\text { Punta Atlas } \\
(\text { Argentina, } \\
\left.\sim 45^{\circ} \mathrm{S}\right) ; \text { not } \\
\text { on Falkland }\end{array}$ & \begin{tabular}{|l} 
south of \\
$\sim 14^{\circ} \mathrm{S}$ in Peru \\
till Chiloe \\
$\left(\sim 42^{\circ} \mathrm{S}\right)$
\end{tabular} & $\begin{array}{l}\text { magellanic } \\
\text { South } \\
\text { America, } \\
\text { Patagonia } \\
\text { north of } \\
\text { Beagle } \\
\text { Channel, } \\
\text { Falkland Is. }\end{array}$ \\
\hline
\end{tabular}


Table 1.1 continued

\begin{tabular}{|c|c|c|c|c|c|c|c|c|c|}
\hline Blades & L. brevifolia & L. adamsiae & L. tholiformis & L. variegata* & L. corrugata & L. ovata & L. nigrescens $*$ & L. trabeculata & L. flavicans \\
\hline Shape & ovalate & linear, fragile & $\begin{array}{l}\text { linear } \\
\text { lanceolate }\end{array}$ & $\begin{array}{l}\text { linear } \\
\text { lanceolate }\end{array}$ & $\begin{array}{l}\text { linear } \\
\text { ensiform }\end{array}$ & $\begin{array}{l}\text { linear- } \\
\text { ovalate with } \\
\text { a wide blade } \\
\text { base angle }\end{array}$ & linear & $\begin{array}{l}\text { linear or linear } \\
\text { lanceolate }\end{array}$ & $\begin{array}{l}\text { linear } \\
\text { lanceolate }\end{array}$ \\
\hline $\begin{array}{l}\text { Margins \& } \\
\text { general } \\
\text { appearance }\end{array}$ & $\begin{array}{l}\text { glandulated, } \\
\text { with } \\
\text { microscopic } \\
\text { superficial } \\
\text { verrucosities }\end{array}$ & \begin{tabular}{|l|} 
dentated, \\
with little \\
teeth $15-$ \\
30mm distant
\end{tabular} & $\begin{array}{l}\text { teeth up to } \\
5 \mathrm{~mm} \text { long and } \\
\text { tipped with a } \\
\text { stiff, dark, } \\
\text { oval knob; } \\
\text { spaced at } 15- \\
25 \mathrm{~mm} \\
\text { intervals }\end{array}$ & $\begin{array}{l}\text { distantly } \\
\text { papilated; } \\
\text { surface } \\
\text { smooth or } \\
\text { longitudinally } \\
\text { wrinkled }\end{array}$ & $\begin{array}{l}\text { with alternate } \\
\text { spines, } 5 \mathrm{~mm} \\
\text { long with } \\
\text { broad base; } \\
\text { surface } \\
\text { rugose with } 5 \\
\text { or more } \\
\text { parallel } \\
\text { longitudinal } \\
\text { ribs }\end{array}$ & denticulated & $\begin{array}{l}\text { finely } \\
\text { dentated }\end{array}$ & $\begin{array}{l}\text { smooth or } \\
\text { dentated }\end{array}$ & dentated \\
\hline $\begin{array}{l}\text { Corrugated / } \\
\text { smooth }\end{array}$ & smooth & corrugated & $\begin{array}{l}\text { smooth } \\
\text { (juv. } \\
\text { rugulose) }\end{array}$ & smooth & corrugated & smooth & smooth & smooth & smooth \\
\hline Long $(\mathrm{cm})$ & $9.8-12.3 \mathrm{~cm}$ & $50-150 \mathrm{~cm}$ & $50-70 \mathrm{~cm}$ & $60 \mathrm{~cm}$ & $91 \mathrm{~cm}$ & $\begin{array}{l}17- \\
86(100) \mathrm{cm}\end{array}$ & $(-)$ & $(-)$ & \begin{tabular}{|l}
$(8) 12-$ \\
$68(89) \mathrm{cm}$ \\
\end{tabular} \\
\hline Width $(\mathrm{cm})$ & $\begin{array}{l}\text { narrow } \\
2-(3) 9 \mathrm{~cm}\end{array}$ & $\begin{array}{l}\text { broad } \\
7-11 \mathrm{~cm}\end{array}$ & $\begin{array}{l}\text { narrow } \\
5-7(10) \mathrm{cm}\end{array}$ & $\begin{array}{l}\text { v. narrow } \\
1-4(7) \mathrm{cm}\end{array}$ & $\begin{array}{l}\text { v. narrow } \\
3-5 \mathrm{~cm}\end{array}$ & $\begin{array}{l}\text { v. broad } \\
6-40 \mathrm{~cm}\end{array}$ & $\begin{array}{l}\text { v. narrow } \\
1-4 \mathrm{~cm}\end{array}$ & $\begin{array}{l}\text { narrow 1- } \\
12 \mathrm{~cm} ; \\
\text { or } 0.9-8.6 \text { in } \\
\text { undivided, } \\
1.7-12.4 \text { in } \\
\text { splitting } \\
\text { blades }\end{array}$ & $\begin{array}{l}\text { narrow } \\
2-(6) 9 \mathrm{~cm}\end{array}$ \\
\hline $\begin{array}{l}\text { Thickness } \\
(\mu \mathrm{m})\end{array}$ & $600-690$ & $350-400$ & $500-1100$ & $530-650$ & $430-570$ & $\begin{array}{l}\text { v. thin; 300- } \\
400\end{array}$ & - & - & $400-900$ \\
\hline
\end{tabular}


Table 1.1 continued

\begin{tabular}{|c|c|c|c|c|c|c|c|c|c|}
\hline & L. brevifolia & L. adamsiae & L. tholiformis & L. variegata* & L. corrugata & L. ovata & L. nigrescens $*$ & L. trabeculata & L. flavicans \\
\hline Pigmentation & $\begin{array}{l}\text { uniform; } \\
\text { dark brown }\end{array}$ & uniform & $\begin{array}{l}\text { irregular } \\
\text { brownish } \\
\text { flecks }\end{array}$ & $\begin{array}{l}\text { striated } \\
\text { flecked; } \\
\text { light yellow to } \\
\text { olive-yellow } \\
\text { or olive-green }\end{array}$ & $\begin{array}{l}\text { uniform; } \\
\text { olive with a } \\
\text { greenish } \\
\text { tinge }\end{array}$ & $\begin{array}{l}\text { uniform; } \\
\text { dark brown }\end{array}$ & $\begin{array}{l}\text { uniform; } \\
\text { dark green, } \\
\text { almost } \\
\text { blackish }\end{array}$ & uniform; brown & $\begin{array}{l}\text { uniform; } \\
\text { brown }\end{array}$ \\
\hline Lustre dried & suede-like & shiny & & shiny & shiny & shiny & shiny & shiny(?) & suede-like \\
\hline $\begin{array}{l}\text { width of } \\
\text { medulla }(\mu \mathrm{m})\end{array}$ & $80-130$ & $50-60$ & 100 & $80-90$ & $150-170$ & up to 25 & up to 100 & up to 50 & up to 50 \\
\hline $\begin{array}{l}\text { No. cell rows } \\
\text { in meristoderm }\end{array}$ & 1 & 1 & 1 & 1 & 1 & $1-2$ & $2-3$ & $2-3$ & $1-2$ \\
\hline $\begin{array}{l}\text { No. cell layers } \\
\text { in cortex }\end{array}$ & $\begin{array}{l}7-10 \\
(-)\end{array}$ & $\begin{array}{l}4-6 \\
(-)\end{array}$ & $\begin{array}{l}\sim 8 \\
\text { polygonal } \\
\text { cells }\end{array}$ & $\begin{array}{l}7-10 \\
(-)\end{array}$ & $\begin{array}{l}6-8 \\
(-)\end{array}$ & $\begin{array}{l}5-8 \\
\text { rectangular } \\
\text { cells }\end{array}$ & $\begin{array}{l}10-16 \\
\text { polygonal } \\
\text { cells }\end{array}$ & $\begin{array}{l}7-15 \\
\text { polygonal cells }\end{array}$ & $\begin{array}{l}5-8 \\
\text { polygonal } \\
\text { cells }\end{array}$ \\
\hline $\begin{array}{l}\text { Cortex } \\
\text { lacunate / solid }\end{array}$ & lacunate & lacunate & lacunate & lacunate & lacunate & solid & solid & $\begin{array}{l}\text { lacunate, } \\
\text { with trabeculae }\end{array}$ & lacunate \\
\hline $\begin{array}{l}\text { Paraphyses } \\
\text { length }(\mu \mathrm{m}) \\
\text { width }(\mu \mathrm{m})\end{array}$ & $\begin{array}{l}(-) \\
(-)\end{array}$ & $\begin{array}{l}(-) \\
(-)\end{array}$ & $\begin{array}{l}(70-80) \\
(8-9) \text { at tip }\end{array}$ & $\begin{array}{l}80 \text { with a } \\
\text { hialine hat; } 20 \\
\text { wide }\end{array}$ & $\begin{array}{l}(-) \\
(-)\end{array}$ & $\begin{array}{l}54.4-64.7 \\
5.6-9\end{array}$ & $\begin{array}{l}18.1-75.4 \\
1.3-5.7\end{array}$ & $\begin{array}{l}42-59 \\
5-8\end{array}$ & $\begin{array}{l}52.7-66 \\
5.5-7.8\end{array}$ \\
\hline $\begin{array}{l}\text { Sporangia } \\
\text { length }(\mu \mathrm{m}) \\
\text { width }(\mu \mathrm{m})\end{array}$ & $\begin{array}{l}(-) \\
(-)\end{array}$ & $\begin{array}{l}50-60 \\
6-7\end{array}$ & $\begin{array}{l}(50-65) \\
(9-11)\end{array}$ & $\begin{array}{l}50-65 \\
10\end{array}$ & $\begin{array}{l}(-) \\
(-)\end{array}$ & $\begin{array}{l}34.8-46.4 \\
8.7\end{array}$ & $\begin{array}{l}43.5-55.1 \\
5.8-8.7\end{array}$ & $\begin{array}{l}43 \pm 4.7 \\
5.8-8.7\end{array}$ & $\begin{array}{l}29-43.5 \\
4.4-7.3\end{array}$ \\
\hline
\end{tabular}


Table 1.1 continued

\begin{tabular}{|c|c|c|c|c|c|c|c|c|c|}
\hline Branches & L. brevifolia & L. adamsiae & L. tholiformis & L. variegata* & L. corrugata & L. ovata & L. nigrescens* & L. trabeculata & L. flavicans \\
\hline $\begin{array}{l}\text { No. emerging } \\
\text { from base or } \\
\text { holdfast of } \\
\text { mature algae }\end{array}$ & $1-2(4)$ & $\begin{array}{l}\text { commonly } \\
5-15\end{array}$ & $10-25$ & up to 100 & $100+$ & $\begin{array}{l}1 \\
1-2\end{array}$ & up to 20 & $1-29(47)$ & $\begin{array}{l}1-2(4 \text { or } \\
\text { more in } \\
\text { young algae })\end{array}$ \\
\hline $\begin{array}{l}\text { No. emerging } \\
\text { from holdfast } \\
\text { of juvenile } \\
\text { algae }(<20 \mathrm{~cm})\end{array}$ & 1 & 1 & $(-)$ & 1 & 1 & 1 & numerous & $1(?)$ & 1 \\
\hline Flexibility & rigid & rigid & rigid & flexible & v. flexible & rigid & flexible & rigid & rigid \\
\hline $\begin{array}{l}\text { Cross section } \\
\text { shape }\end{array}$ & oval-terete & $\begin{array}{l}\text { terete at base, } \\
\text { oval distally }\end{array}$ & $\begin{array}{l}\text { oval or } \\
\text { rounded, } \\
\text { flattened near } \\
\text { blades }\end{array}$ & $\begin{array}{l}\text { oval or } \\
\text { irregular at } \\
\text { base, flattened } \\
\text { distally }\end{array}$ & $\begin{array}{l}\text { subterete at } \\
\text { base, } \\
\text { flattening to } \\
\text { the top }\end{array}$ & oval-terete & $\begin{array}{l}\text { terete at base, } \\
\text { flattening to } \\
\text { the top }\end{array}$ & $\begin{array}{l}\text { oval-terete } \\
\text { terete of } \\
\text { subteret, } \\
\text { flattening to } \\
\text { the top }\end{array}$ & oval-terete \\
\hline $\begin{array}{l}\text { Max. branch } \\
\text { width }(\mathrm{mm})\end{array}$ & $\sim 40$ & 60 & $20-40$ & 20 & 20 & 50 & 40 & $(-)$ & $(-)$ \\
\hline $\begin{array}{l}\text { Cortex } \\
\text { lacunate / solid }\end{array}$ & lacunate & lacunate & large cavities & solid & solid & solid & solid & $\begin{array}{l}\text { lacunate; } \\
\text { lacunae with } \\
\text { trabeculae }\end{array}$ & $\begin{array}{l}\text { spherical } \\
\text { or } \\
\text { ellipsoidal } \\
\text { lacunae }\end{array}$ \\
\hline $\begin{array}{l}\text { Branching } \\
\text { pattern }\end{array}$ & $\begin{array}{l}\text { dichotomous } \\
(3-4 \\
\text { dichotomies })\end{array}$ & $\begin{array}{l}\text { dichotomous } \\
\text { (4-5 } \\
\text { dichotomies) }\end{array}$ & dichotomous & $\begin{array}{l}\text { forking from } \\
\text { the base, 6-7 } \\
\text { times at } \\
\text { narrow } \\
\text { angles; } \\
\text { twisted } \\
\text { branches }\end{array}$ & $\begin{array}{l}\text { dichotomous } \\
\text { (6 } \\
\text { dichotomies), } \\
\text { cuneate } \\
\text { widening of } \\
\text { the stem } \\
\text { below each } \\
\text { dichotomy }\end{array}$ & $\begin{array}{l}\text { dichotomous } \\
\text { or subdich. } \\
\text { branched }\end{array}$ & $\begin{array}{l}\text { dichotomously } \\
\text { branched }\end{array}$ & $\begin{array}{l}\text { dichotomous } \\
\text { or subdich. in } \\
\text { the uppermost } \\
\text { portions; 3-4 } \\
\text { times furcate } \\
\text { to mid } \\
\text { portions }\end{array}$ & $\begin{array}{l}\text { dichotomous } \\
\text { or subdich. } \\
\text { branched; } \\
\text { uneven } \\
\text { branching } \\
\text { might lead } \\
\text { to v. tall and } \\
\text { thick trunks } \\
(8 \mathrm{~m} ?)\end{array}$ \\
\hline
\end{tabular}


Table 1.1 continued

\begin{tabular}{|c|c|c|c|c|c|c|c|c|c|}
\hline $\begin{array}{l}\text { Holdfast or } \\
\text { base }\end{array}$ & L. brevifolia & L. adamsiae & L. tholiformis & L. variegata* & L. corrugata & L. ovata & L. nigrescens* & L. trabeculata & L. flavicans \\
\hline $\begin{array}{l}\text { Appearance } \\
\text { of mature } \\
\text { algae }\end{array}$ & $\begin{array}{l}\text { more-or-less } \\
\text { hapteroid; } \\
\text { stoloniferous }\end{array}$ & $\begin{array}{l}\text { massive, } \\
\text { asymmetrical, } \\
\text { a coalescence } \\
\text { of holdfast, } \\
\text { basal branches } \\
\& \text { haptera }\end{array}$ & $\begin{array}{l}\text { semi-solid } \\
\text { dome or } \\
\text { mound } \\
\text { formed by } \\
\text { overlapping } \\
\text { layers of } \\
\text { flattened, } \\
\text { lobed haptera } \\
\text { (similar to } L . \\
\text { nigrescens); } \\
\text { building a } \\
\text { conical mass }\end{array}$ & $\begin{array}{l}\text { massive, } \\
\text { woody, } \\
\text { brittle; } \\
\text { dichotomousl } \\
\text { y branched } \\
\text { haptera; } \\
\text { spreading; } \\
\text { circular } \\
\text { outline }\end{array}$ & $\begin{array}{l}\text { strong and } \\
\text { scutiform, } \\
\text { spreading }\end{array}$ & $\begin{array}{l}\text { dissected, with } \\
\text { unfused } \\
\text { dichotomously } \\
\text { branched } \\
\text { haptera; more- } \\
\text { or-less } \\
\text { hapteroid }\end{array}$ & $\begin{array}{l}\text { massive, } \\
\text { conical or } \\
\text { hemi-spherical } \\
\text { mound of } \\
\text { tightly fused } \\
\text { haptera }\end{array}$ & $\begin{array}{l}\text { massive, } \\
\text { asymmetric } \\
\text { and } \\
\text { irregularly } \\
\text { shaped, a } \\
\text { coalescence of } \\
\text { holdfast, basal } \\
\text { branches \& } \\
\text { haptera; 13- } \\
20 \text { cm height; } \\
\text { wenn young } \\
\text { haptera are } \\
\text { free or only } \\
\text { partially fused }\end{array}$ & $\begin{array}{l}\text { dissected, with } \\
\text { unfused } \\
\text { dichotomously } \\
\text { branched } \\
\text { haptera; more- } \\
\text { or-less } \\
\text { hapteroid }\end{array}$ \\
\hline Buttresses & none & $\begin{array}{l}\text { tall, rounded } \\
\text { buttresses }\end{array}$ & none & $\begin{array}{l}\text { buttresses rib- } \\
\text { like }\end{array}$ & none & none & none & $\begin{array}{l}\text { rounded } \\
\text { buttresses }\end{array}$ & none \\
\hline
\end{tabular}


Table 1.1 continued

\begin{tabular}{|c|c|c|c|c|c|c|c|c|c|}
\hline & L. brevifolia & L. adamsiae & L. tholiformis & L. variegata* & L. corrugata & L. ovata & L. nigrescens* & $\begin{array}{l}\text { L. } \\
\text { trabeculata }\end{array}$ & L. flavicans \\
\hline Synonymy & none & none & none & none & none & $\begin{array}{l}\text { L. searlesiana } \\
\text { Asensi \& de } \\
\text { Reviers }\end{array}$ & $\begin{array}{l}\text { Chordaria } \\
\text { spicata } \text { Suhr; } \\
\text { Laminaria } \\
\text { scissa } \text { Suhr; } \\
\text { Lessonia suhrii } \\
\text { J.Agardh; } \\
\text { Lessonia } \\
\text { berteroana } \\
\text { Mont.; } \\
\text { Lessonia } \\
\text { nigrescens } f \text {. } \\
\text { montagnei } \\
\text { Skottsberg }\end{array}$ & none & $\begin{array}{l}\text { Lessonia } \\
\text { fuscescens } \\
\text { Bory; } \\
\text { Lessonia } \\
\text { frutescens } \\
\text { Skottsberg; } \\
\text { Lessonia } \\
\text { nigrescens f. } \\
\text { lacunifera } \\
\text { Skottsberg; } \\
\text { Lessonia } \\
\text { vadosa } \\
\text { Searles }\end{array}$ \\
\hline $\begin{array}{l}\text { Misapplied } \\
\text { names }\end{array}$ & $\begin{array}{l}\text { L. flavicans } \\
\text { (Hay et. al } \\
1985) ; \text { L. } \\
\text { fuscescens and } \\
\text { L. variegata } \\
\text { (Papenfuss } \\
\text { 1964) }\end{array}$ & $\begin{array}{l}\text { L. variegata } \\
\text { (Hay et. al } \\
1985)\end{array}$ & & & & $\begin{array}{l}\text { L. flavicans } \\
\text { sensu Searles; } \\
\text { L. frutescens } \\
\text { sensu Searles }\end{array}$ & none & $\begin{array}{l}\text { L. flavicans; } \\
\text { L. fuscescens }\end{array}$ & $\begin{array}{l}\text { L. nigrescens } \\
\text { sensu } \\
\text { Skottsberg }\end{array}$ \\
\hline Sources & $(5,6,8)$ & $(6,8)$ & $(7)$ & $(3,6,8)$ & $(2,6,8)$ & $(1,4,6,8)$ & $(1,4,6,8)$ & $(1,8)$ & $(1,4,6,8)$ \\
\hline
\end{tabular}




\subsection{Lessonia - Biology and dispersal}

Algae are very important in all marine, freshwater, and some terrestrial systems around the world. They are primary producers and a leading source of free oxygen. However, algae are not monophyletic and this dissertation is restricted to the Phaeophyceae (brown algae) and in particular to one genus of the Laminariales (kelp), namely Lessonia (strap kelp).

The Laminariales are a significant floristic component of the intertidal and subtidal zones on almost any rocky coast in temperate and polar seas. They are referred to as being the most structurally complex of all algae as they are divided into lamina, stem, and holdfast (Bold and Wynne 1978). Kelp communities create forest-like environments on the sea floor where they offer structure (Lessonia can form canopies but would in most areas belong to the understory), habitat (e.g., for epi- or endophytes), shelter (e.g., for fish recruits), and food (e.g., copepods, isopods, and sea urchins, but also Paua (Haliotis sp.) and Butterfish (Odax sp.)) to marine life (e.g., Dayton 1985, Lobban \& Harrison 1994, Francis 2001, Nelson 2005). The Laminariales are characterized as being parenchymatous with several different cell layers (medulla, cortex, and meristoderm), growing in length by an intercalary meristem, having anisogamous reproduction, and a heteromorphic $\left(\mathrm{D}^{\mathrm{h}}\right)$ life cycle (Fig 1.10), involving a macroscopic sporophyte and microscopic, dioecious gametophytes (e.g., Bold and Wynne 1978, Womersley 1987). Lessonia sporophytes, as in many other Laminariales, are perennial (Adams 1994), with a major growing phase during summer (Tala et al. 2004, Nelson 2005, Schwarz et al. 2006) and peak reproduction of gametophytes in winter (Tala et al. 2004, Schwarz et al. 2006), followed by peak sporulation of sporophytes in spring/early summer 
(Schwarz et al. 2006). Extensive sori form in the middle of each blade. When ripe, spores are released in clumps of mucus (Markey \& Wilce 1976, Toth 1976, Hoffmann \& Camus 1989), which usually sink to the bottom near the parent (Norton 1992, Dayton 1973, Reed et al. 1988, Forrest et al. 2000, Faugeron et al. 2005, Kusumo et al. 2006) and attach to the substrate where they grow into male and female gametophytes.

Dispersal can occur in short, medium, or long distances in many different ways (Fig. 1.10). As short-distance-dispersal (SDD) I understand the dispersal of propagules (spores and sperm). It is the main consensus that this form of dispersal is limited to a few meters (Norton 1992, Dayton 1973, Reed et al. 1988, Santelices 1990, Forrest et al. 2000, Faugeron et al. 2005, Kusumo et al. 2006), but the radius might increase if whole stands sporulate simultaneously (Norton 1992). In Lessonia, spores are released in large drops of mucus (Markey \& Wilce 1976, Toth 1976, Hoffmann \& Camus 1989) that usually have enhanced sinking rates (as polysaccharides are heavier than water) if not trapped in surface tension (Santelices 1990). The advantage of enhanced sinking rates in heterogeneous environments is that spores will more likely find suitable habitat in the neighbourhood of the parent than further away (Moorjani \& Jones 1972). Higher sinking rates seem to be also an adaptation to exposed environments (Taylor \& Schiel 2003). An often used argument against successful fertilisation after enhanced dispersal of spores is the dilution effect and the requirement that male and female gametophytes have to be in high numbers and close proximity (i.e., $>10 / \mathrm{mm}^{2}$; Reed 1990a) for successful fertilisation as female pheromones and male sperms are limited in their ability to disperse (e.g., Faugeron et al. 2005). This constraint is more valid for expanding populations but 
less for the connectivity of existing populations, and spores have been detected $4 \mathrm{~km}$ downstream of the source populations, and might travel even further (Reed 1988). A requirement for settlement, however, is the stickiness of the spore that decreases with time and thus also constrains the dispersal distance (Santelices 1990, Taylor \& Schiel 2003).

Dispersal is also possible via drifting of detached individuals or fertile thallus fragments. In contrast to floating, drifting is used here for detached algae that are or became negatively buoyant and tumble over the sea floor in shallow water driven by tidal or wind-induced currents (Thiel \& Gutow 2005a). Individuals of Lessonia are very hard to detach (pers. obs.); nevertheless, piles of detached algae are often seen washed up on beaches after heavy winter storms (e.g., Schiel \& Foster 2006); the season coincides with the time of peak reproduction (see above). Not by chance, the first account of Lessonia translates: "Cast ashore by tempests, this algae oft aggregates huge dykes surpassing a yard in vertical stature, and if one were to step upon this seaborne effigy then that poor soul would become much entangled in an ankle deep mire of putrefaction, releasing an unendurable and malodorous assault on one's olfactory senses, which one could only compare with that of a cauliflower in an advanced state of decomposition." (d'Urville 1825). Drift was reported to cover 100 to $1000 \mathrm{~m} /$ year in Undaria pinnatifida, another non-floating kelp (Forrest et al. 2000). Dispersal of algal fragments is likely to span the same distance but might occur more often (Forrest et al. 2000). Laminae grow all year round to compensate the distal loss of older tissue that is shredded by waves and currents (Tala \& Edding 2005). If fronds are fertile the most likely area where the lamina breaks apart is below the sorus, leaving short blades behind. [This appearance might have led to the 
description of L. brevifolia Agardh. L. brevifolia is a species endemic to the SubAntarctic Islands of New Zealand, however, the laminas are not short as described but have a length and appearance comparable to the laminas of Lessonia variegata (pers. obs.)]. Another form of medium-distance-dispersal (MDD) is saltation. Saltation means the dispersal of specimen growing on unstable substrate, like small rocks, by currents lifting the whole alga together with the rock and releasing it further downstream. Saltation was observed in Undaria pinnatifida where the dispersal distance was assumed to span 10 to $100 \mathrm{~m} /$ year (Sliwa et al. 2006).

As Lessonia is negatively buoyant its only possibility for long-distancedispersal (LDD) seems to be as gametophytes or sporophytes attached to other floating devices. Floating devices might be pumice, wood, plastic, etc. (Thiel \& Gutow 2005a), but also other brown algae such as Macrocystis pyrifera (Skottsberg (1907) stated that his L. frutescens specimen was collected with a Macrocystis holdfast from shallow water) or Durvillaea antarctica (Fig. 1.11). These two algae grow in overlapping habitats together with Lessonia (Searles 1978, Edding et al. 1994) and are known for their floating abilities. An estimated 70 million rafts (20 million supporting a holdfast) of Durvillaea antarctica are afloat in the Southern Ocean at any given time (Smith 2002) and both kelp species, Durvillaea and Macrocystis, have each been found to share a single haplotype throughout the Southern Hemisphere (Macaya \& Zuccarello 2010, Fraser et al. 2009). LDD via floating or rafting might cover distances from $<100 \mathrm{~km}$ up to $>5000 \mathrm{~km}$ (Thiel \& Haye 2006). Theoretically free-drifting spores also have the ability of LDD. Amsler $\&$ Searles (1980) report colonization over a distance of at least $35 \mathrm{~km}$ via spore dispersal (in Reed et al. 1992). Hoffmann \& Camus (1989) reported that spores of $L$. 
nigrescens were still able to germinate after four days in suspension. Amsler \& Neushul (1991) state that the ability of some algal spores to photosynthesise might increase dispersal distance. Reed et al. (1992) found that some algal spores remain swimming up to $120 \mathrm{~h}$ under photosynthetically saturating irradiance and will not necessarily die after they stopped swimming, as some germinated in suspension. His laboratory observations indicate that free-floating spores might develop into gametophytes, which are still able to settle, fertilize and grow into sporophytes (Reed et al. 1992). Positive phototaxis, which was found in some algal spores, also increases dispersal distance (Norton 1992). Spores might even get trapped in surface tension and remain floating (Santelices 1990). However despite these in vitro experiments, which can theoretically increase the possibility of connectivity and colonisation over long distances, the odds are low, as successful settlement decreases with distance, as mortality of the microscopic stages is very high, as planktonic grazing will decrease the chances of survival with time, and as successful fertilisation requires high densities (i.e., $>10 / \mathrm{mm}^{2}$ ) of gametophytes (Santelices 1990, Reed 1990a, Schiel \& Foster 2006).

In general the ability of dispersal strongly affects the possibility of diversification and speciation of disjunct populations. For example, due to floating structures, the high dispersal abilities in Macrocystis pyrifera and Durvillaea antarctica have led, in both algae, to highly connected populations and for each species a single haplotype has been detected throughout the Southern Hemisphere on islands and continents connected by the West Wind Drift (Fraser et al. 2009, Macaya \& Zuccarello 2010). In Macrocystis this has led to multiple morphological species being merged into a single morphologically plastic species, $M$. pyrifera (Coyer et al. 
2001, Macaya \& Zuccarello 2010). On the other hand, species that lack floating structures, have been reported to show genetic structure over short distances, e.g., Lessonia nigrescens (Martinez et al. 2003, Faugeron et al. 2005), Ecklonia radiata (Coleman et al. 2009), Postelsia palmaeformis (Kusumo et al. 2004 and 2006), and Laminaria digitata (Billot et al. 2003). The dispersal ability of a species is known to influence the connectivity and genetic structure of populations, but also the ability to colonize and speciate (e.g., Ross et al. 2009). Thus knowledge of the dispersal ability is helpful for the interpretation of questions asked in a phylogeographic and population genetic framework. 


\subsubsection{Figures}

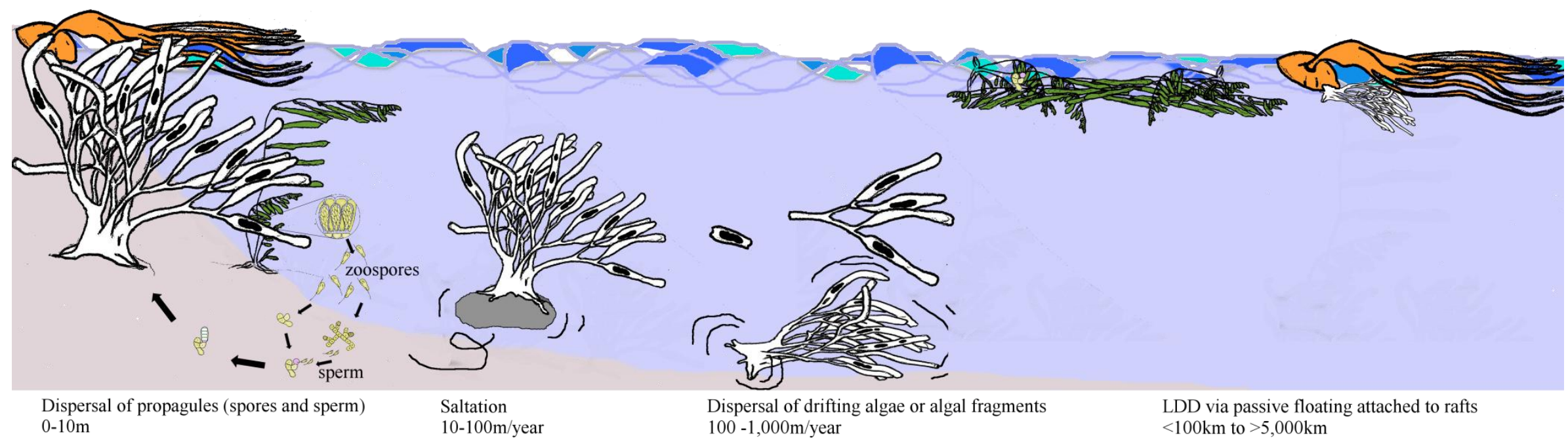

Fig. 1.10 Possible dispersal mechanisms in Lessonia. The different modes of dispersal include dispersal of propagules (spores and sperm), which is associated with the life cycle and mainly spans distances between 0-10m (e.g., Norton 1992), however, spores have been detected 4km downstream of the source populations (Reed 1988). Saltation was investigated in Undaria pinnatifida where it was accounted for dispersal between 10-100m/year (Sliwa et al. 2006). In the same study dispersal of drifting algae and algal fragments was assumed to span 100-1,000m/year. Rafting of gametophytes and sporophytes attached to floating devices might allow dispersal over distances $<100 \mathrm{~km}$ to $>5,000 \mathrm{~km}$ (Thiel \& Haye 2006). Possible rafts for Lessonia are the two floating species Macrocystis pyrifera and Durvillaea antarctica, which have overlapping habitats with Lessonia. 


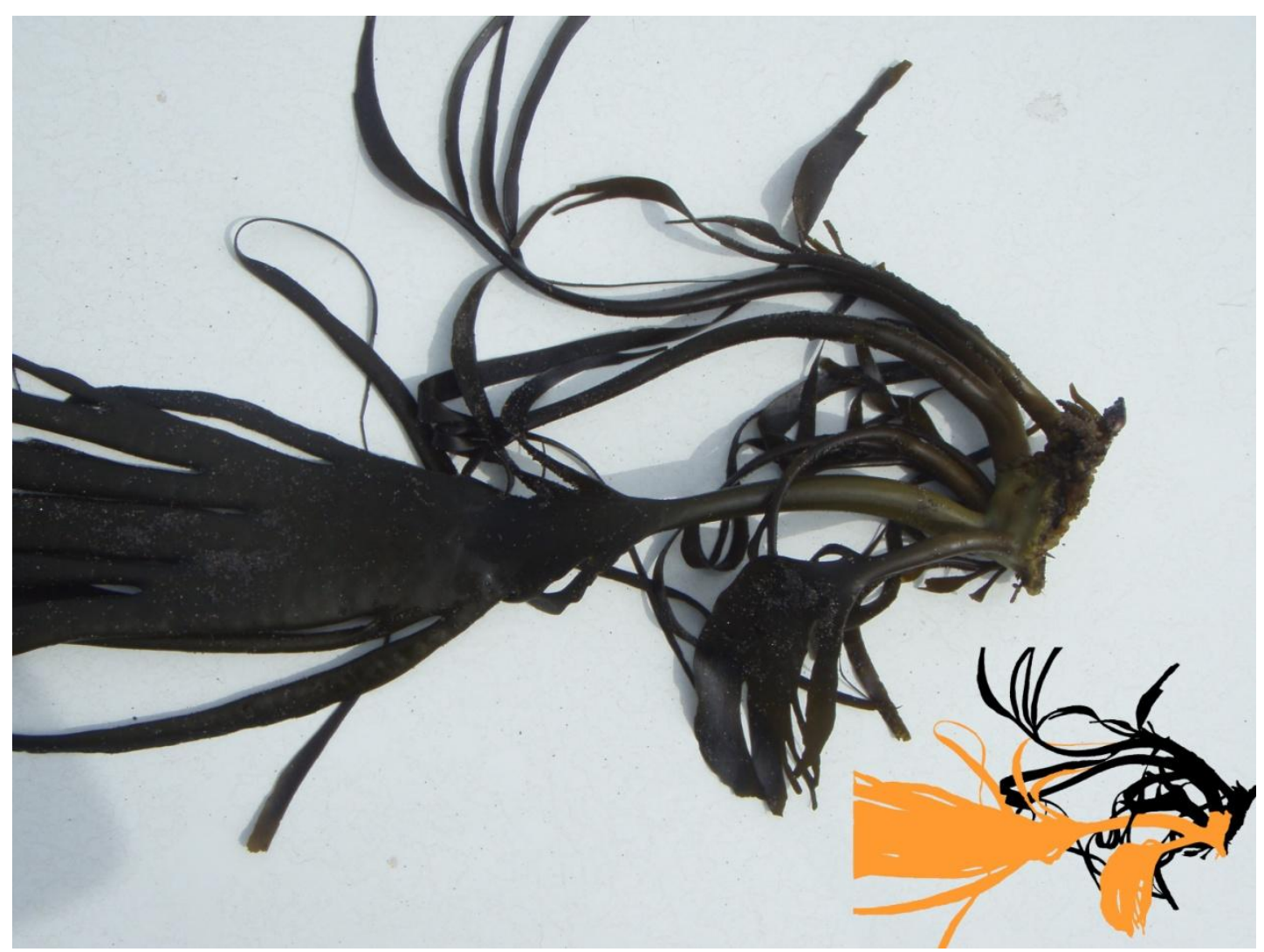

Fig. 1.11 Durvillaea antarctica (orange in insert) overgrowing a Lessonia nigrescens (black in insert) holdfast. (Photo taken by C. Fraser). 


\subsection{Lessoniceae - New molecular taxonomy and phylogeny}

Taxonomy is originally based on morphological and/or anatomical features and in many cases these are good tools to predict natural inheritance. As taxonomic hypotheses improve with the complexity of the feature(s) used, morphology often fail to resolve a natural lineage in taxa with high morphological plasticity (Lane et al. 2007) or where morphological traits are few (Zuccarello \& West 2003). In some of these cases, genetics can help to find the true phylogenetic relationships.

Setchell \& Gardner (1925) were the first to recognize the Lessoniaceae among five other families within the order Laminariales. The advanced and morphologically more complex families (Alariaceae, Laminariaceae, and Lessoniaceae or ALL-complex) have remained uncontested in their species composition until Fain et al. (1988), who were the first to use molecular techniques to the systematics of Laminariales, found that the Lessoniaceae were polyphyletic. Half a decade later Saunders \& Druehl (1993) commenced the reorganization of the families based on sequence data with a revision of the Alariaceae. Little by little every single family of the ALL-complex has found to be polyphyletic (Druehl et al., 1997; Kawai \& Saskia, 2000; Yoon et al., 2001) and has finally let to a substantial taxonomic re-organization (Lane et al. 2006) (Table 1.2).

In the Lane et al. (2006) survey, the Lessoniaceae Setchell \& Gardner was subject to the most fundamental changes with Lessonia being the only genus remaining in the family. The genera Dictyoneuropsis and Dictyoneurum were transferred to the new proposed family Costariaceae. Most genera, i.e., Macrocystis, Nereocystis, Pelagophycus and Postelsia, were transferred to the Laminariaceae and 
later also Lessonia laminarioides, which was previously known as the only Lessonia species from the Northern Hemisphere, was reclassified as Pseudolessonia laminarioides (Cho et al. 2006) and likewise placed within the Laminariaceae. Prior to the changes of Lane et al. (2006), Saunders and Dreuhl (1993) recommended moving Lessoniopsis to the Alariaceae and emended the description of this group. Ecklonia, Egregia, and Eisenia formally placed within the Alariaceae, due to the presence of sporophylls (Ecklonia, which has no sporophylls, has, according to the definition made by Setchell \& Gardner, the potential for sporophylls as lateral outgrowths of the blade arising from the transition zone, also, the authors state that early stages of Ecklonia are like those of Eisenia), were moved to the Lessoniaceae, as was Eckloniopsis formally a member of the Laminariaceae, as Eckloniopsis radicosa persistently nests within Ecklonia (Saunders \& Druehl 1993, Yoon et al. 2001, Lane et al. 2006). Lane et al. (2006) suggested reviewing the status of Eckloniopsis in favour of a single genus Ecklonia. The new assemblage of genera within the Lessoniaceae is not supported in any other molecular study known to me (Druehl et al. 1997, Boo et al. 1999, Kawai \& Sasaki 2000, Yoon et al. 2001, Phillips et al. 2008, McDevit \& Saunders 2009) and it seems that Egregia is the reason. The faster evolving sequences of Egregia, and long-branch attraction, have also been a problem for Lane et al. (2006), but due to a large dataset in terms of species number and number of molecular markers, they were able to give statistical support to this assemblage. Within the Lessoniaceae, three groups were recognized, two are monogeneric (Lessonia and Egregia) and one combines the genera Eisenia, Ecklonia, and Eckloniopsis. Due to the difficult placement of Egregia, the Ecklonia clade was chosen to be the primary source for outgroup selection for Lessonia phylogeny. Another possible outgroup became apparent through the work of Lee et 
al. (2008), who catalogued Northern and Southern Hemisphere brown algae while using the barcoding gene COI, and who found a close relationship between Lessonia and Laminaria ephemera. In Lane et al.'s (2006) study, L. ephemera was found nested within other Laminaria species. At the very least these contrasting results reveal how little we still know about kelp systematics.

The major reorganizations made by Lane et al. (2006) have required a critical editing of the genus descriptions. Lane et al. (2006) described the new proposed Costariaceae as follows:

Costariaceae Lane, Mayes, Druehl et Saunders: Members of the Laminariales that generally have a flattened stipe but are occasionally terete, and either a perforated or reticulated blade, or both. Type genus: Costaria; additional genera: Agarum, Dictyoneurum and Thalassiophyllum.

The Alariaceae have been earlier revised by Saunders \& Druehl (1993):

Alariaceae Setchell \& Gardner 1925 emend. Saunders \& Druehl 1993: Fronds consisting of a simple vegetative lamina with a central midrib or thickening, terminating a simple or dichotomously branched primary stipe. Sporophylls developing from the intercalary meristem situated at the stipe-lamina transition zone, distichously arranged on the primary stipe. Other features as characteristic of the order Laminariales. Type genus: Alaria; additional genera: Lessoniopsis, Pleurophycus, Pterygophora, and Undaria.

No revision, however, was made for the Laminariaceae and Lessoniaceae as they both circumscribe a morphologically diverse assemblage of taxa that are not as 
easily defined as the previous groups. Yet, based on the generic composition after Lane et al. (2006) the description of the Lessoniaceae could be amended to:

Lessoniaceae Setchell \& Gardner 1925:591,621: Holdfast branched hapteroid; blades without midrib or central thickening; no sporophylls arising from the primary stipe (i.e., between holdfast and the intercalary meristem or, in other words, below the first vegetative frond). From here the Lessoniaceae are best described as two different entities. A) Lessonia, Ecklonia (including 'Eckloniopsis'), and Eisenia: lacking pneumatocysts, a round to terete and overall solid, not hollow stipe (with the exception of Ecklonia maxima and some Ecklonia kurome specimens); the transition zone might give rise to splitting (Lessonia) or outgrows (Eisenia); distribution bipolar (Ecklonia, Eisenia) or solely in the Southern Hemisphere (Lessonia; unique among all Laminariales). Sporophylls arising from the primary blade (Eisenia) or if absent (Lessonia, Ecklonia) sporangia might develop in the middle of vegetative blades; B) Egregia: multiple, flattened stipes bearing pneumatocysts and sporophylls that develop randomly among the vegetative bladelets along the whole length of the stipe margin above the primary part of the stipe (the sporophylls in Egregia are believed to be due to parallel evolution analogous to any other sporophylls and are a distinguishing feature for Egregia); Egregia is the only Lessoniaceae that is found solely in the Northern Hemisphere. 
Table 1.2 Taxonomic changes of the Laminariales over time.

\begin{tabular}{|c|c|c|}
\hline $\begin{array}{l}\text { Taxonomy of the Laminariales Oltmanns after } \\
\text { Setchell \& Gardner } 1925\end{array}$ & $\begin{array}{l}\text { Taxonomy of the Laminariales Migula 1909:243 } \\
\text { (formally often referred to Kylin 1919) as listed } \\
\text { in Systema Naturae } 2000\end{array}$ & $\begin{array}{l}\text { Taxonomy of the ALL-group after Lane et al. } \\
\text { (2006) }\end{array}$ \\
\hline $\begin{array}{l}\text { Lessoniaceae Setchell \& Gardner 1925:591,621 } \\
\text { (splitting at the transition zone between the stipe } \\
\text { and the blade) }\end{array}$ & Lessoniaceae & Lessoniaceae Post. \& Rupr. (...) \\
\hline Tribe: Lessonieae Setchell & Lessonia Bory, 1825 & Lessonia \\
\hline Dictyoneurum Rupr., 1852 & Dictyoneurum & \\
\hline Nereocystis Post. and Rupr., 1840 & Nereocystis & \\
\hline Postelsia Rupr., 1852 & Postelsia & \\
\hline \multicolumn{3}{|l|}{ Tribe: Macrocysteae Kuetzing (lim. mut.) } \\
\hline Macrocystis C.A. Agardh, 1820 & Macrocystis & \\
\hline Pelagophycus Aresch., 1881 & Pelagophycus & \\
\hline \multicolumn{3}{|l|}{ Tribe: Lessoniopseae Setchell } \\
\hline \multirow[t]{6}{*}{ Lessoniopsis Reinke, 1903} & Lessoniopsis & \\
\hline & Dictyoneuropsis G.M. Smith, 1942 & \\
\hline & & Ecklonia \\
\hline & & Eckloniopsis \\
\hline & & Egregia \\
\hline & & Eisenia \\
\hline $\begin{array}{l}\text { Laminariaceae Reichenb. [single blades, either } \\
\text { simple or longitudinally split but never with the } \\
\text { splits extending into the transition zone.] }\end{array}$ & $\begin{array}{l}\text { Laminariaceae (the accepted authority is Bory, } \\
1827: 63 \text { ) }\end{array}$ & Laminariaceae Post. \& Rupr. (...) \\
\hline \multicolumn{3}{|l|}{ Tribe: Laminarieae Bory (lim. mut.) } \\
\hline Laminaria Lamour.,1813 (in part) & Laminaria Lamouroux, 1813, nom. cons. & Laminaria \\
\hline Tribe: Cymathaereae Setchell and Gardner & & \\
\hline
\end{tabular}


Table 1.2 continued

\begin{tabular}{|c|c|c|}
\hline $\begin{array}{l}\text { Pleurophycus Setchell \& Saunders ex J.Tilden, } \\
1900\end{array}$ & Pleurophycus & \\
\hline Cymathaere J. Agardh., 1868 & Cymathaere & $\begin{array}{l}\text { Saccharina (resurrected) Stackh., } 1809 \\
{[++ \text { Cymathaere japonica, Hedophyllum, }} \\
\text { Kjellmaniella }]\end{array}$ \\
\hline \multicolumn{3}{|l|}{ Tribe: Agareae Kuetz. (lim. mut) } \\
\hline Costaria Greville, 1830 & Costaria & \\
\hline Thalassiophyllum Post. \& Rupr., 1840 & Thalassiophyllum & \\
\hline Agarum (Bory) Post. \& Rupr. & Agarum Bory, 1826, nom. cons. & \\
\hline \multicolumn{3}{|l|}{ Tribe: Hedophyllaea Setchell } \\
\hline Hedophyllum Setchell, 1901 & Hedophyllum & Hedophyllum see Saccharina \\
\hline \multirow[t]{11}{*}{ Arthrothamnus Rupr., 1848} & Arthrothamnus & Arthrothamnus \\
\hline & Costularia C.B. Clarke, in Thiselton-Dyer, 1898 & \\
\hline & $\begin{array}{l}\text { Feditia Yu. Petrov \& I. Gusarova, in I. Gusarova } \\
\text { \& Yu. Petrov, } 1972\end{array}$ & \\
\hline & Kjellmaniella Miyabe in Okamura, 1902 & \\
\hline & $\begin{array}{l}\text { Phyllariella Y.E. Petrov \& V.B. Vozzhinskaya, } \\
1966\end{array}$ & \\
\hline & $\begin{array}{l}\text { Streptophyllum K. Miyabe \& M. Nagai, in Nagai, } \\
1940\end{array}$ & $\begin{array}{l}\text { Streptophyllopsis ("based on available } \\
\text { information" but was not sequenced) }\end{array}$ \\
\hline & & Macrocystis \\
\hline & & Nereocystis \\
\hline & & Pelagophycus \\
\hline & & Postelsia \\
\hline & & $\begin{array}{l}\text { Pseudolessonia G. Y. Cho, N. G. Klochkova, T. } \\
\text { N. Krupnova et Boo, } 2006\end{array}$ \\
\hline
\end{tabular}




\begin{tabular}{|c|c|c|}
\hline $\begin{array}{l}\text { Alariaceae Setchell \& Gardner,1925:591,633 } \\
\text { [with sporophylls] }\end{array}$ & Alariaceae & $\begin{array}{l}\text { Alariaceae Post. and Rupr. (sporophylls that } \\
\text { derive from the stipe, but Pleurophycus) }\end{array}$ \\
\hline \multicolumn{3}{|l|}{ Tribe: Alarieae Setchell } \\
\hline Pterygophora Rupr. 1852 & Pterygophora & Pterygophora \\
\hline Alaria Greville 1830 , nom. cons. & Alaria & Alaria \\
\hline Tribe: Ecklonieae Setchell & Ecklonia J.W. Hornemann, 1828 & \\
\hline Eisenia Aresch., 1876 & Eisenia & \\
\hline \multicolumn{3}{|l|}{ Tribe: Egregieae Setchell } \\
\hline \multirow[t]{6}{*}{ Egregia Aresch., 1876} & Egregia & \\
\hline & Eckloniopsis K. Okamura, 1927 & \\
\hline & Undaria W.F.R. Suringar, 1873 & Undaria \\
\hline & & (Undariella) \\
\hline & & $\begin{array}{l}\text { Lessoniopsis (added by Saunders and Druehl } \\
\text { 1993b) }\end{array}$ \\
\hline & & Pleurophycus \\
\hline Chordaceae Dumort. & Chordaceae & Chordaceae \\
\hline \multirow[t]{8}{*}{ Chorda Stackh., 1797} & Chorda & Chorda \\
\hline & Halosiphon Jaasund, 1957 & \\
\hline & Pseudochordaceae & $\begin{array}{l}\text { Costariaceae C.E. Lane, Mayes, Druehl et G.W. } \\
\text { Saunders fam. nov. (Members of the } \\
\text { Laminariales that generally have a flattened stipe } \\
\text { but are occasionally terete, and either a } \\
\text { perforated or reticulated blade, or both.) }\end{array}$ \\
\hline & & Costaria \\
\hline & Phyllariaceae & Agarum \\
\hline & Phyllaria (A. Le Jolis) J. Rostafinski, 1877 & Dictyoneurum \\
\hline & Phyllariopsis E.C. Henry \& G.R. South, 1987 & (Dictyoneuropsis) \\
\hline & $\begin{array}{l}\text { Saccorhiza Bachelot de la Pylaie, 1830, nom. } \\
\text { cons. }\end{array}$ & Thalassiophyllum \\
\hline
\end{tabular}




\subsection{References}

Adams, N. 1994. Seaweeds of New Zealand, An illustrated Guide. Canterbury University Press, Christchurch, 360 pp.

Agardh, J. G. 1841. In historiam algarum symbolae. Linnaea 15:1-50, 443-57.

Agardh, J. G. 1877. De Algis Novae Zelandiae marinis. Lunds Universitets ÅrsSkrift, Afdelningen for Mathematik och Naturvetenskap 14:1-32.

Agardh, J. G. 1894. Analecta algologica. Continuatio II. E. Malmstroems Boktryckeri, Lund, 99 pp.

Amsler, C. D. \& Neushul, M. 1991. Photosynthetic physiology and chemicalcomposition of spores of the kelps Macrocystis pyrifera, Nereocystis leutkeana, Laminaria farlowii, and Pterygophora californica (Phaeophyceae). J. Phycol. 27:26-34.

Amsler, C. D. \& Searles, R. B. 1980. Vertical-distribution of seaweed spores in a water column offshore of North-Carolina. J. Phycol. 16:617-19.

Asensi, A. \& de Reviers, B. 2009. Illustrated catalogue of types of species historically assigned to Lessonia (Laminariales, Phaeophyceae) preserved at PC, including a taxonomic study of three South-American species with a description of $L$. searlesiana sp. nov. and a new lectotypification of $L$. flavicans. Cryptogam. Algol. 30:209-49.

Barrales, H. \& Lobban, C. S. 1975. The comparative ecology of Macrocystis pyrifera, with emphasis on the forest of Chubut, Argentina. J. Ecol. 63:65775. 
Billot, C., Engel, C. R., Rousvoal, S., Kloareg, B. \& Valero, M. 2003. Current patterns, habitat discontinuities and population genetic structure: the case of the kelp Laminaria digitata in the English Channel. Mar. Ecol. Prog. Ser. 253:111-21.

Bold, H. C. \& Wynne, M. J. 1978. Introduction to the algae. Structure and reproduction. Prentice-Hall, Inc., New Jersey, 706 pp.

Bolton, J. J. 2010. The biogeography of kelps (Laminariales, Phaeophyceae): a global analysis with new insights from recent advances in molecular phylogenetics. Helgol. Mar. Res. 64:263-79.

Boo, S. M., Lee, W. J., Yoon, H. S., Kato, A. \& Kawai, H. 1999. Molecular phylogeny of Laminariales (Phaeophyceae) inferred from small subunit ribosomal DNA sequences. Phycol. Res. 47:109-14.

Bory de Saint-Vincent, J. B. 1825. Cryptogamie. In: Dumont-D'Urville, J. S. C. [Ed.] Flore des Iles Malouines. De L'Imprimerie de Lebel, Imprimeur du Roi, Paris, pp. 21-56 (separate).

Bory de Saint-Vincent, J. B. 1826. Lessonie. Lessonia. In: Audouin, I., et \& al [Eds.] Dictionnaire Classique d'Histoire Naturelle. pp. 321-22.

Bory de Saint-Vincent, J. B. 1828. Cryptogamie. In: Duperrey, L. I. [Ed.] Voyage autour du monde, exécuté par ordre du Roi, sur la corvette de sa majesté, La Coquille, pendant les années 1822, 1823, 1824 et 1825. Bertrand, Paris, pp. $1-301$ 
Cho, G. Y., Klochkova, N. G., Krupnova, T. N. \& Boo, S. M. 2006. The reclassification of Lessonia laminarioides (Laminariales, Phaeophyceae): Pseudolessonia gen. nov. J. Phycol. 42:1289-99.

Coleman, M. A., Gillanders, B. M. \& Connell, S. D. 2009. Dispersal and gene flow in the habitat-forming kelp, Ecklonia radiata: relative degrees of isolation across an east-west coastline. Mar. Freshw. Res. 60:802-09.

Cotton, A. D. 1915. Cryptogams from the Falkland Islands collected by Mrs. Vallentin. Journal of the Linnean Society of London, Botany 43:137-231.

Coyer, J. A., Smith, G. J. \& Andersen, R. A. 2001. Evolution of Macrocystis spp. (Phaeophyceae) as determined by ITS1 and ITS2 sequences. J. Phycol. $37: 574-85$.

Dayton, P. K. 1973. Dispersion, dispersal, and persistence of annual intertidal alga, Postelsia palmaeformis Ruprecht. Ecology 54:433-38.

Dayton, P. K. 1985. Ecology of the kelp communities. Annu. Rev. Ecol. Syst. $16: 215-45$.

Delepine, R. 1963. Observations sur la végétation marine des îles Australes Françaises. Société Phycologique de France 8:9-10.

Dickie, G. 1876. Marine algae collected by Mr. Moseley at the island of Kerguelen. Journal of the Linnean Society of London, Botany 15:43-47.

Dickie, G. 1879. Marine algae (exclusive of the Diatomaceae). Philos. Trans. R. Soc. Lond. B Biol. Sci. 168 (extra vol.):53-64. 
Druehl, L. D., Mayes, C., Tan, I. H. \& Saunders, G. W. 1997. Molecular and morphological phylogenies of kelp and associated brown algae. Plant Syst. Evol.:221-35.

D'Urville, J. S. C. 1825. Flore des Iles Malouines. De L'Imprimerie de Lebel, Imprimeur du Roi, Paris, 56 pp. (separate).

Edding, M. E., Fonk, E. A. \& Macchiavello, J. E. 1994. Lessonia. In: Akatsuka, I. [Ed.] Biology of Economic Algae. SPB Academic Pubishing, The Hague, pp. 407-446.

Fain, S. R., Druehl, L. D. \& Baillie, D. L. 1988. Repeat and single copy sequences are differentially conserved in the evolution of kelp chloroplast DNA. $J$. Phycol. 24:292-302.

Faugeron, S., Martinez, E. A., Correa, J. A. \& Billot, C. 2005. Long-term copper mine waste disposal in northern Chile associated with gene flow disruption of the intertidal kelp Lessonia nigrescens. Mar. Ecol. Prog. Ser. 288:129-40.

Forrest, B. M., Brown, S. N., Taylor, M. D., Hurd, C. L. \& Hay, C. H. 2000. The role of natural dispersal mechanisms in the spread of Undaria pinnatifida (Laminariales, Phaeophyceae). Phycologia 39:547-53.

Francis, M. P. 2001. Coastal fishes of New Zealand. An identification guide. Reed Books, Auckland, 103 pp.

Fraser, C. I., Nikula, R., Spencer, H. G. \& Waters, J. M. 2009a. Kelp genes reveal effects of Sub-Antarctic sea ice during the Last Glacial Maximum. Proc. Natl. Acad. Sci. U. S. A. 106:3249-53. 
Guiry, M. D. G., G.M. 2011. AlgaeBase. World-wide electronic publication, National University of Ireland, Galway. http://www.algaebase.org; searched on 13 January 2011.

Hay, C. H. 1987. Lessonia adamsiae sp. nov. (Phaeophyta, Laminariales) from the Snares Islands, New-Zealand. N. Z. J. Bot. 25:295-308.

Hay, C. H. 1989. Lessonia tholiformis sp. nov. (Phaeophyta, Laminariales) from the Chatham Islands, New-Zealand. N. Z. J. Bot. 27:461-69.

Hay, C. H., Adams, N. M. \& Parsons, M. J. 1985. Marine Algae of the Sub-Antarctic Islands of New Zealand. National Museum of New Zealand, Wellington, 69 pp.

Hoffmann, A. J. \& Camus, P. 1989. Sinking rates and viability of spores from benthic algae in central Chile.pdf. J. Exp. Mar. Biol. Ecol. 126:281-91.

Hooker, J. D. 1847. The botany of the Antarctic voyage of H.M. discovery ships Erebus and Terror, in the years 1839-1843, under the command of Captain Sir James Clark Ross... I. Flora Antarctica. Part II. Botany of Fuegia, the Falklands, Kerguelen's Land, etc. Reeve, Brothers, Natural History Lithographers, London, 209-574, Plates LXXXI-CXCVII.

Hooker, J. D. 1867. Order IX. Algae. Handbook of the New Zealand flora: a systematic description of the native plants of New Zealand and the Chatham, Kermadec's, Lord Auckland's. Reeve, London, pp. 638-721.

Kawai, H. \& Sasaki, H. 2000. Molecular phylogeny of the brown algal genera Akkesiphycus and Halosiphon (Laminariales), resulting in the circumscription 
of the new families Akkesiphycaceae and Halosiphonaceae. Phycologia $39: 416-28$.

Kusumo, H. T., Pfister, C. A. \& Wootton, J. T. 2006. Small-scale genetic structure in the sea palm Postelsia palmaeformis Ruprecht (Phaeophyceae). Mar. Biol. 149:731-42.

Kusumo, H. T., Pfister, C. A. \& Wootton, J. T. 2004. Dominant (AFLP) and codominant (microsatellite) markers for the kelp Postelsia palmaeformis (Laminariales). Mol. Ecol. Notes 4:372-75.

Kützing, F. T. 1849. Species algarum. F.A. Brockhaus, Lipsiae [Leipzig], [i]-vi, [1]922.

Laing, R. M. 1894. On Lessonia variegata. Transactions and Proceedings of the New Zealand Institute 26:304-10.

Lane, C. E., Lindstrom, S. C. \& Saunders, G. W. 2007. A molecular assessment of northeast Pacific Alaria species (Laminariales, Phaeophyceae) with reference to the utility of DNA barcoding. Mol. Phylogenet. Evol. 44:634-48.

Lane, C. E., Mayes, C., Druehl, L. D. \& Saunders, G. W. 2006. A multi-gene molecular investigation of the kelp (Laminariales, Phaeophyceae) supports substantial taxonomic re-organization. J. Phycol. 42:493-512.

Lee, S.-Y., Jung, M.-Y., Kim, J. H., Kang, S.-H., Chung, H. \& Choi, H.-G. 2008 November 10-14. DNA barcoding of brown algae around two Korean stations in the Antarctic and the Arctic. Poster session presented at: Algae in 
a changing world. Vth Asian Pacific Phycological Forum. Wellington, New Zealand.

Lindauer, V. W., Chapman, V. J. \& Aiken, M. 1961. The marine algae of New Zealand. Part II. Phaeophyceae. Nova Hedwigia 3:129-350, Tab. 57-97.

Lobban, C. \& Harrison, P. 1994. Seaweeds Ecology and Physiology. Cambridge University Press, New York, 366 pp.

Lucas, A. H. S. 1931. Notes on Australian marine algae. VI. Descriptions of six new species. Proc. Linn. Soc. N. S. W. 56:407-11.

Macaya, E. C. \& Zuccarello, G. C. 2010. DNA barcoding and genetic divergence in the giant kelp Macrocystis (Laminariales). J. Phycol. 46:736-42.

Markey, D. R. \& Wilce, R. T. 1976. The ultrastructure of reproduction in the brown alga Pylaiella littoralis II. Zoosporogenesis in the unilocular sporangia. Protoplasma 88:147-73, (with 43 Figures).

Martinez, E. A. 1999. Latitudinal differences in thermal tolerance among microscopic sporophytes of the kelp Lessonia nigrescens (Phaeophyta: Laminariales). Pac. Sci. 53:74-81.

Martinez, E. A., Cardenas, L. \& Pinto, R. 2003. Recovery and genetic diversity of the intertidal kelp Lessonia nigrescens (Phaeophyceae) 20 years after El Nino 1982/83. J. Phycol. 39:504-08.

McDevit, D. C. \& Saunders, G. W. 2009. On the utility of DNA barcoding for species differentiation among brown macroalgae (Phaeophyceae) including a novel extraction protocol. Phycol. Res. 57:131-41. 
Montagne, C. 1842. Troisième centurie de plantes cellulaires exotiques nouvelles. Décades V, VI, VII et VIII. Annales des Sciences Naturelles, Botanique, Seconde Série 18:241-82, Plate 7.

Moorjani, S. \& Jones, W. F. 1972. Spore attachment and development in some coralline alga. Br. Phycol. J. 7:282.

Nelson, W. A. 2005. Life history and growth in culture of the endemic New Zealand kelp Lessonia variegata J. Agardh in response to differing regimes of temperature, photoperiod and light. J. Appl. Phycol. 17:23-28.

Norton, T. A. 1992. Dispersal by Macroalgae.pdf. Eur. J. Phycol. 27:293-301.

Papenfuss, G. F. 1964. Catalogue and bibliography of Antarctic and Sub-Antarctic benthic marine algae. In: Lee, M. O. [Ed.] Biology of the Antarctic seas. American Geophysical Union, Washington, pp. 1-76.

Phillips, N., Burrowes, R., Rousseau, F., de Reviers, B. \& Saunders, G. W. 2008. Resolving evolutionary relationships among the brown algae using chloroplast and muclear genes. J. Phycol. 44:394-405.

Postels, A. \& Ruprecht, F. 1840 (reprint 1963). Illustrationes Algarum. Wheldon \& Wesley, Ltd and Hafner Publishing Co., New York, 24, (with 40 Figures).

Ramírez, M. \& Santelices, B. 1991. Catálogo de las Algas Marinas Bentónicas de la Costa Templada del Pacífico de Sudamérica. Facultad de Ciencias Biológicas, Pontificia Universidad Católica de Chile, Santiago, 437.

Reed, D. C. 1990. The effects of variable settlement and early competition on patterns of kelp recruitment. Ecology 71:776-87. 
Reed, D. C., Amsler, C. D. \& Ebeling, A. W. 1992. Dispersal in kelps - factors affecting spore swimming and competence. Ecology 73:1577-85.

Reed, D. C., Laur, D. R. \& Ebeling, A. W. 1988. Variation in algal dispersal and recruitment. Ecol. Monogr. 58:321-35.

Ross, P. M., Hogg, I. D., Pilditch, C. A. \& Lundquist, C. J. 2009. Phylogeography of New Zealand's coastal benthos. N. Z. J. Mar. Freshw. Res. 43:1009-27.

Santelices, B. 1990. Patterns of reproduction, dispersal and recruitment in seaweeds. Oceanography and Marine Biology 28:177-276.

Saunders, G. W. \& Druehl, L. D. 1993. Revision of the Kelp Family Alariceae and the Taxonomic Affinities of Lessoniopsis Reinke (Laminariales, Phaeophyta). Hydrobiologia 261:689-97.

Schiel, D. R. 1990. Macroalgal Assemblages in New-Zealand - Structure, Interactions and Demography. Hydrobiologia 192:59-76.

Schiel, D. R. \& Foster, M. S. 2006. The population biology of large brown seaweeds: Ecological consequences of multiphase life histories in dynamic coastal environments. Annu. Rev. Ecol. Evol. Syst. 37:343-72.

Schiel, D. R. \& Hickford, M. J. H. 2001. Biological structure of nearshore rocky subtidal habitats in southern New Zealand. Science for Conservation 182:154.

Schwarz, A.-M., Hawes, I., Nelson, W. \& Andrew, N. 2006. Growth and reproductive phenology of the kelp Lessonia variegata in central New Zealand. N. Z. J. Mar. Freshw. Res. 40:273-84. 
Searles, R. B. 1978. Genus Lessonia Bory (Phaeophyta, Laminariales) in Southern Chile and Argentina. Br. Phycol. J. 13:361-81.

Setchell, W. A. \& Gardner, N. L. 1925. The Marine Algae of the Pacific coast of North America. University of California Press, Berkley, 898 pp.

Skottsberg, C. 1907. Zur Kenntnis der Subantarktischen und Antarktischen Meeresalgen I. Phaeophyceen b. Lessoniaea. In: Nordenskjöld, O. [Ed.] Wissenschaftliche Ergebnisse der Schwedischen Südpolar-Expedition, 19011903. Kungl., Boktryckeriet, Stockholm, pp. 69-80.

Skottsberg, C. 1921. Botanische Ergebnisse der Schwedischen Expedition nach Patagonien und dem Feuerlande 1907-1909. VIII Marine Algae 1. Phaeophyceae. Kungliga Svenska Vetenskapsakademiens Handlingar 61:156.

Sliwa, C., Johnson, C. R. \& Hewitt, C. L. 2006. Mesoscale dispersal of the introduced kelp Undaria pinnatifida attached to unstable substrata. Bot. Mar. 49:396-405.

Smith, S. D. A. 2002. Kelp rafts in the Southern Ocean. Glob. Ecol. Biogeogr. 11:67-69.

Suhr, J. N. v. 1839. Beiträge zur Algenkunde. Flora 22:65-75.

Suhr, J. N. v. 1841. Beiträge zur Algenkunde. Verhandlungen der Kaiserlichen Leopoldinisch-Carolinischen Akademie der Naturforscher 18:273-88.

Tala, F. \& Edding, M. 2005. Growth and loss of distal. tissue in blades of Lessonia nigrescens and Lessonia trabeculata (Laminariales). Aquat. Bot. 82:39-54. 
Tala, F., Edding, M. \& Vasquez, J. 2004. Aspects of the reproductive phenology of Lessonia trabeculata (Laminariales : Phaeophyceae) from three populations in northern Chile. N. Z. J. Mar. Freshw. Res. 38:255-66.

Taylor, D. I. \& Schiel, D. R. 2003. Wave-related mortality in zygotes of habitatforming algae from different exposures in southern New Zealand: the importance of 'stickability'. J. Exp. Mar. Biol. Ecol. 290:229-45.

Tellier, F., Meynard, A. P., Correa, J. A., Faugeron, S. \& Valero, M. 2009. Phylogeographic analyses of the $30^{\circ} \mathrm{S}$ south-east Pacific biogeographic transition zone establish the occurrence of a sharp genetic discontinuity in the kelp Lessonia nigrescens: Vicariance or parapatry? Mol. Phylogenet. Evol. 53:679-93.

Thiel, M. \& Gutow, L. 2005. The ecology of rafting in the marine environment. I. The floating substrata. Oceanography and Marine Biology: An Annual Review 42:181-264.

Thiel, M. \& Haye, P. A. 2006. The ecology of rafting in the marine environment. III. Biogeographical and evolutionary consequences. Oceanography and Marine Biology: An Annual Review 44:323-429.

Toth, R. 1976. A mechanism of propagule release from unilocular reproductive structures in brown algae. Protoplasma 89:263-78, (with 26 Figures).

Vega, J. M. A., Vasquez, J. A. \& Buschmann, A. H. 2005. Population biology of the subtidal kelps Macrocystis integrifolia and Lessonia trabeculata (Laminariales, Phaeophyceae) in an upwelling ecosystem of Northern Chile: 
Interannual variability and El Nino 1997-1998. Rev. Chil. Hist. Nat. 78:3350.

Villouta, E. \& Santelices, B. 1986. Lessonia trabeculata sp. nov. (Laminariales, Phaeophyta), a New Kelp from Chile. Phycologia 25:81-86.

Womersley, H. B. S. 1987. The marine benthic flora of South Australia Part II [Covers Phaeophyta.]. South Australian Government Printing Division, Adelaide, 484 pp.

Yoon, H. S., Lee, J. Y., Boo, S. M. \& Bhattacharya, D. 2001. Phylogeny of Alariaceae, Laminariaceae, and Lessoniaceae (Phaeophyceae) based on plastid-encoded RuBisCo spacer and nuclear-encoded ITS sequence comparisons. Mol. Phylogenet. Evol. 21:231-43.

Zuccarello, G. C. \& West, J. A. 2003. Multiple cryptic species: Molecular diversity and reproductive isolation in the Bostrychia radicans/B-moritziana complex (Rhodomelaceae, Rhodophyta) with focus on North American isolates. $J$. Phycol. 39:948-59. 


\section{Chapter 2 Molecular Phylogeny and timing of radiation in Lessonia (Phaeophyceae, Laminariales)}

\subsection{Abstract}

The genus Lessonia is distributed solely in the Southern Hemisphere, with four species found in South America and five in Australasia. My goal was to determine the evolutionary relationships between the Lessonia species of the two disjunct areas. I combined plastid, nuclear and mitochondrial markers in a comprehensive dataset from several individuals per known species. Furthermore, for some species I added samples from multiple populations to take account of their widespread distribution over known bioregions. The results suggested that Australasian Lessonia form a monophyletic group and that South American species form a paraphyletic group. Delimitations of the accepted species are highly supported except for L. variegata and L. nigrescens. I showed for the first time four lineages for the New Zealand endemic Lessonia variegata with an unexpected high level of genetic differentiation that justifies a split into four species. Molecular clock analysis suggested that Lessonia is young with a Southern Hemisphere radiation in the Pliocene more recent than 5 Mya. A sudden radiation took place in Australasia ca. 3.5 Mya when almost all Australasian species diverged within a time frame of only 35000 years. 
Key Index words: Australasia, cryptic species, glaciation, Laminariales, Lessonia, molecular clock analysis, New Zealand, Phaeophyceae, phylogeny, South America Abbreviations: atp8-sp, spacer region between atp-dehydrogenase subunit 8 and tRNA serine; CTAB, Cetyltrimethylammonium Bromide; HPD, highest posterior density; ITS, nuclear marker covering the internal transcribed spacers (1 and 2) between the large and small-ribosomal RNA subunits, and the 5.8S ribosomal RNA; MJ, median joining; MP, maximum parsimony; My, million years; Mya, million years ago; nd6, a partial sequence of the gene coding for NADH dehydrogenase subunit 6; NJ, neighbour joining; rbc-sp, spacer between the large and short subunit of the ribulose-1,5-bisphosphate carboxylase/oxygenase gene; trnW-sp, the spacer between the t-RNA's for tryptophan and isoleucine; 


\subsection{Introduction}

The molecular phylogeny of the kelps (Laminariales) has received much attention, due to their ecological importance and charismatic character (Saunders \& Druehl 1992, Lane et al. 2006, McDevit \& Saunders 2009). Supported by molecular evidence, the old morphologically based familial relationships of the Laminariales were fundamentally changed by Lane et al. (2006). In their comprehensive study, no other family was rearranged to the same extent as the Lessoniaceae (Setchell \& Gardner 1925), with only Lessonia left in its original family. Lane et al. (2006) proposed a new grouping consisting of Lessonia, Eisenia, Ecklonia (with Eckloniopsis), and Egregia (all, except Lessonia, were formally placed within the Alariaceae). Egregia however often does not group with other Lessoniaceae sensu Lane et al. (Lane et al. 2006, Phillips et al. 2008, McDevit \& Saunders 2009) with only Lessonia and its sister group of Ecklonia and Eisenia forming a consistent clade. Lessonia is the only genus in this group that is solely distributed in the Southern Hemisphere (Lane et al. 2006).

Despite being a poor disperser (Faugeron et al. 2005), Lessonia is found disjunct in Australasia and South America on exposed rocky shores, between $12^{\circ} \mathrm{S}$ and $56^{\circ}$ S (Lucas 1931, Papenfuss 1964, Barrales \& Lobban 1975, Searles 1978, Hay 1987 and 1989, Fernandez et al. 1999, Martinez 1999). 32 species of Lessonia have been described of which nine are currently recognized (Edding et al. 1994): four in South America (L. flavicans Bory, L. nigrescens Bory, L. trabeculata Villouta \& Santelices, and L. ovata Hook.f. \& Harv.), and five in Australasia (L. adamsiae Hay, L. brevifolia J.Agardh, L. corrugata Lucas, L. tholiformis Hay, and L. variegata J.Agardh); one to two poorly known species have been reported from Kerguelen and 
Heard Island (Delepine 1963, Papenfuss 1964) but are not properly described. Since its original description, the species designation of the South American L. flavicans was ambiguous and it has led to extremely entangled synonyms (Agardh 1878). Despite the latest attempt by Asensi \& de Reviers (2009) the issue is still unresolved, as only specimen preserved at the Muséum National d'Histoire Naturelle were considered in their survey. However I follow Asensi \& de Reviers (2009) suggestion for the designation of L. flavicans Bory but I will use the older epithet L. ovata Hook.f. \& Harv as synonym to the newly described species L. searlesiana Asensi \& de Reviers (see Chapter 6).

The divergence ages of the species of Lessonia is not known. Lüning \& tom Dieck (1990) suggested that "the present-day cold-water algal floras must have evolved as a response to [the two major] climatic deterioration $[\mathrm{s}] \ldots$ at the Eocene/Oligocene boundary [35 million years ago (Mya)], and in the Miocene (1510 Mya)". This view is supported by estimations based on molecular clock analysis using a mutation rate for kelp cpDNA of $0.2-0.4 \% \mathrm{My}^{-1}$ that places the time of the radiation within the Laminariaceae between 8.5 to 34 Mya (Druehl \& Saunders 1992), but more likely between 16 and 20 Mya (Saunders \& Druehl 1992) and the radiation within the genus Laminaria between 15-19 Mya (Stam et al. 1988). That the divergence estimates of Stam et al. (1988) and Saunders \& Druehl (1992) were the same but for different taxonomic levels (family level and genus level respectively) was later corrected by the resurrection of Saccharina (Lane et al. 2006), which split Laminaria into two genera and revealed that Stam et al. (1988) actually investigated familial and not generic radiation. A recent estimate of molecular-derived divergence times, calibrated using diatom $p s b \mathrm{~A}$ (Hoarau et al. 
2007), sets the time of divergence between two laminarialean families (Alariaceae and Laminariaceae) between 10-15 Mya and the mutation rate of the RuBisCo spacer between 0.26 and $0.40 \% \mathrm{My}^{-1}$ (Tellier et al. 2009).

Multiple studies have shown that morphological plasticity in the Laminariales has led to an accumulation of many synonyms (Lane et al. 2007 [Alaria], Uwai et al. 2007 [Undaria], Demes et al. 2009, and Macaya \& Zuccarello 2010 [Macrocystis]); whereas other studies have revealed cryptic species (Sasaki \& Kawai 2007 [Chorda sp.], Tellier et al. 2009 [Lessonia nigrescens Bory]). With the increase of molecular studies in brown algal systematics, the number and relationships of species is expected to change with morphological species merged and cryptic species discovered.

The molecular relationships among the disjunct Lessonia species and the timing of their divergence are still unknown but are important for further biogeographic interpretations. The presence of cryptic species has not been investigated for the Australasian Lessonia, even though cryptic species have been found in Chile (Tellier et al. 2009) and knowledge about biodiversity is central for ecological management and conservation. The aim of this study is to gain a better understanding of the phylogenetic relationships of the Southern Hemisphere genus Lessonia, especially in using molecular data to delimit species, uncover cryptic species, and estimate the timing of divergence within this genus. 


\subsection{Material and Methods}

\subsubsection{Sampling}

A total of 48 individuals of Lessonia were collected from 29 sites throughout the distribution range of the nine recognized species (Fig. 2.1, Table S 2.1). Widespread species like L. variegata, L. nigrescens, and L. trabeculata have been collected from distant sites. Tissue $\left(2-3 \mathrm{~cm}^{2}\right)$ was collected from the base of a blade, where the blade is youngest and free of epiphytes, patted dry and subsequently sealed in bags with silica gel. All southern South American Lessonia are named as indicated by their collectors or for C156 and C160 determined as L. vadosa based on obvious lacunae in the cortex of the blade (Searles 1978). The sample A634 was used in a previous study as L. flavicans (Lane et al. 2006). To ensure that a majority of genetic variation is captured, I surveyed 440 additional specimens from 35 additional populations in Australasia, using the atp8-Sp region, the most variable of the markers (Chapter 3). In the same way, confidence in capturing genetic variation of South American species was given through comparison with a sample rich survey undertaken by Tellier et al. (2009), who sampled 127 individuals from 36 locations.

\subsubsection{DNA extraction, amplification, and sequencing}

DNA extraction was performed using a modified CTAB protocol (Zuccarello \& Lokhorst 2005).

PCR amplifications were performed in $20 \mu \mathrm{L}$ containing $1 \mu \mathrm{L}$ DNA, $1 \mathrm{x}$ buffer (New England BioLabs, Ipswich, MA, USA), 200nM dNTP, 0.4\% BSA, 2.0mM $\mathrm{Mg}^{2+}, 0.32 \mathrm{U}$ Taq polymerase (New England BioLabs), and $0.17 \mathrm{nM}$ of each primer. Five genetic markers were used: three mitochondrial markers; the spacer region 
between adenosine-tri-phosphate dehydrogenase subunit 8 and t-RNA serine (atp8Sp), the spacer between the t-RNA's for tryptophan and isoleucine (trnW-Sp), and a partial sequence of the gene coding for NADH dehydrogenase subunit 6 (nd6); one chloroplast marker, the spacer between the large and short subunit of the ribulose1,5-bisphosphate carboxylase/oxygenase gene (rbc-Sp); and one nuclear marker covering the internal transcribed spacers (1 and 2) between the large and smallribosomal RNA subunits, and the 5.8S ribosomal RNA (ITS). The markers have been selected for independency and to cover all three algal genomes (mitochondrion, chloroplast, and nuclear) and a variety of marker variability (genes and spacer regions) to ideally increase the phylogenetic signal in a combined dataset. For atp8Sp and trnW-Sp I used primers from Voisin et al. (2005). For all other markers I used primers as in Lane et al. (2006), Peters \& Ramirez (2001), and Tai et al. (2001), some of which were modified (Table S 2.2). The reverse primer for nd6 was newly developed to match a Lessonia specific binding site (n6R-5'

TAGATTCACGACCTCCYTGAC 3'). PCR conditions for each marker were as summarized in Fig. S 2.1.

PCR products were purified with ExoSAP-IT (USB, Cleveland, Ohio, USA) and commercially sequenced (Macrogen Inc., Seoul, South Korea).

\subsubsection{Data analysis}

Sequence assembly was performed with forward and reverse sequences in the 'STADEN package' (Staden et al. 2002) using the implementable programs PHRED (Ewing \& Green 1998), PHRAP (Green unpublished [http://bozeman.genome.washington.edu/phrap.docs/phrap.html]), and GAP4 (Bonfield et al. 1995). All sequences were aligned with ClustalW 1.4 (Thompson et 
al. 1994) and subsequently refined by eye in BioEdit ver. 7.0.9.0 (Hall 1999). The five alignments were used in a combined dataset ("matrix-I"; main dataset) to calculate neighbour joining (NJ) trees in MEGA 4.0 (Tamura et al. 2007), maximum parsimony (MP) trees with PAUP* 4.0 (Swofford 2002), maximum likelihood (ML) trees with PHYML v2.4.4 (Guindon \& Gascuel 2003), and Bayesian trees with MrBayes v3.1.2 (Ronquist \& Huelsenbeck 2003). The compatibility between the datasets was tested with the incongruence-length difference test (Farris et al. 1995) implemented in PAUP* (Table S 2.3). To test sensitivity and dependency of the results to variations in the alignment, I performed a second alignment using different underlying algorithms. Therefore I aligned the ingroup for each marker region with MUSCLE v. 3.8 (Edgar 2004), ambiguously aligned regions were removed with GBLOCKS 0.91b (Castresana 2000). Before the filtered sequences were concatenated I aligned the outgroup taxa to the data using MUSCLE and deleted insertions in the outgroup. The second supermatrix was called matrix-II and was only constructed to verify the results, which are based on the first dataset (matrix-I). Testing different alignments is especially useful when using hypervariable markers such as spacer regions to avoid unanticipated and unintentional bias in the data. The variability of the markers and their degree of saturation has been tested while plotting corrected distances against uncorrected distances (Verbruggen \& Theriot 2008) (Table 2.1, Fig. S 2.2). Sequence divergences (p-distances and HKY-distances (Hasegawa et al. 1985)) between species and lineages were calculated using PAUP*.

With reference to the taxonomic study of Lane et al. (2006) on the Laminariales, I chose Ecklonia as outgroup. To reduce uncertainties to the status of characters, I applied a multiple outgroup approach with one specimen each from $E$. 
radiata (C.Agardh) J.Agardh and E. cava Kjellman. To ensure independency to the outgroup selection, I tested the stability of the topology while applying additional genera to the outgroup. The tested taxa were Eisenia bicyclis (Kjellman) Setchell, Macrocystis pyrifera (Linnaeus) C.Agardh, Undaria pinnatifida (Harvey) Suringar, and Laminaria ephemera Setchell. I also tested the possibility of rooting the phylogenetic trees without outgroups (i.e., mid-point rooting or rooting under a molecular clock assumption). Both approaches require clock-like evolution to some extent but in the case of midpoint rooting, only the two most divergent lineages are required to have evolved at the same rate (Verbruggen \& Theriot 2008). Clock-like evolution was tested in PAUP*. The NJ tree was calculated under a LogDet (Tamura \& Kumar 2002) model of sequence evolution with 10000 bootstrap replications.

An unweighted MP tree was calculated with 1000 heuristic search replicates and TBR branch-swapping. Bootstrap values (Felsenstein 1985) were calculated using ten random additions under the heuristic search method.

Likelihood settings were calculated with Modeltest 3.7 (Posada \& Crandall 1998). The best fit model selected by AIC was the GTR+I+G model. ML bootstraps were calculated with 500 replicates (in PHYML; BIC=-7872).

The alignments for the Bayesian analysis (in MrBayes) were partitioned by marker regions and in case of the nd6 additionally by codon position. The partition strategy was selected against two other strategies (single partition or one partition for each marker) based on its Bayes Factor (log BF) (Table S 2.4) using the implement in TRACER v.1.5. GTR $+\mathrm{I}+\mathrm{G}$ was applied to all partitions allowing for separate values for each partition. The overall rate was allowed to be different across partitions. Five million generations were analysed in each of the two four-chain runs. 
Trees were sampled every thousand generations. Stationary was visualised in TRACER v.1.5 (Rambaut \& Drummond 2007) to adjust the burn-in period before the trees have been summarized.

Divergence times were calculated in BEAST v.1.5.2 (Drummond \& Rambaut 2007) using an uncorrelated log-normal distribution for a relaxed clock model. I tested three calibration strategies that were based on different assumptions of divergence time between laminarialean taxa. The three different settings (A-C) were run, each time using only one of these calibration strategies. Priors for the calibration strategies were: A) a uniform distribution for the tmrca of Ecklonia and Lessonia between 8.5-34 Mya, based on within-family radiation (Druehl \& Saunders 1992; however Saunders \& Druehl (1992) favour radiation between 16 and 20 Mya); B) a uniform distribution for the time of the most recent common ancestor (tmrca) between Ecklonia and Lessonia between 15-19 Mya, based on the within-family radiation of Laminariaceae (Stam et al. 1988, with taxonomic changes after Lane et al. 2006, and similar to Saunders \& Druehl 1992); C) estimates of mutation rates calibrated to the divergence time between Alaria and Laminaria between 10 to 15 Mya [Tellier et al. 2009 following Hoarau et al. (2007), who introduced a heterokont molecular clock for $p s b \mathrm{~A}]$. Beside the estimate for rbc-Sp acquired from Tellier $e t$ al. (2009) I calculated mutation rates for the atp8-Sp region, trnW-Sp region, nd6gene, and nuclear ITS (Appendix S1.E) to be used as priors (ucld.mean) in calibration strategy $\mathrm{C}$.

Additional priors used in all three calibration strategies were as follows. The substitution models and clock models were unlinked; whereas the trees were linked to the nd6 partition tree (the tree likelihood with nd6 linkage was the highest, even 
though no other linkage was significantly worse). Substitution models and partitions were applied as described for the Bayesian tree. To account for the species-level phylogeny I used the Yule prior to be shared by all tree models. The starting tree was randomly generated. The MCMC chain length was set to 15 million and the parameters were logged every 500 generation resulting in 30,000 logged trees. For each calibration strategy three runs were performed, to allow for different starting points, and subsequently combined with LogCombiner v1.5.4. TreeAnnotator v1.5.4 (both programs are available in BEAST v1.5.4 package) was used to produce a single target tree with all information summarized. This tree was finally refined in FigTree v1.2.3 (http://tree.bio.ed.ac.uk/software/figtree/) to create a publishable output. If the posterior values values would not level in all runs or if the posterior values were significantly different between runs, I extracted the best $25 \%$ of the trees (based on their posterior probabilities) after the runs had been combined to be summarized in TreeAnnotator v1.5.4.

Differences in the topological reconstruction (i.e., the root placement) have been tested with TREEFINDER version of October 2008 (Jobb 2008).

Base composition was calculated in MEGA 4.0 to construct a matrix of pair wise differences in GC content. This was used to assess the amount of compositional heterogeneity between the lineages. 


\subsection{Results}

The mtDNA atp8-Sp yielded a dataset of 153bp (gaps removed) and was the most variable of the markers with $45(29.4 \%)$ variable (v) sites out of which 37 were parsimony informative (p.i.). Gaps were removed from all the datasets and thus yielded datasets of: $227 \mathrm{bp}(56(24.7 \%)$ v/ 52 p.i.) for trnW-Sp; the first $860 \mathrm{bp}$ (126 $(14.7 \%)$ v/ 115 p.i.) of the nd6-gene; $331 b p(12$ (3.6\%) v/ 11 p.i.) for rbc-Sp; and 709 bp (95 (13.4\%) v/ 86 p.i.) for ITS. Within 126 variable sites of the nd6-gene 32 were at the first codon position, 17 at the second and 77 at the third. None of the markers used showed signs of saturation but for the $3^{\text {rd }}$ position of the nad6-gene in the outgroup comparison, the ingroup however was unaffected by saturation (Fig. S 2.2).

The incongruence-length test, used to evaluate compatibility between datasets, yielded a $\mathrm{p}$-value $=0.06$. Cunningham (1997) suggested that $\mathrm{p}$-values $>$ 0.01 indicate that combining the data will generally improve the accuracy of the phylogeny. The combined dataset had a length of 2280bp (Table 2.1).

Species delimitations were overall well supported in all tree inference methods (Bayesian, ML, MP, and NJ) of the combined dataset (Fig. 2.2), except for L. variegata and $L$. nigrescens. The data revealed four clades of $L$. variegata from New Zealand, all of which had high support (Fig. 2.2). The species epithet, based on the variegation of the blades, has only been found in the Wellington lineage $[L$. variegata/W, lineage named after the type locality of $L$. variegata (Agardh 1878)].

Despite intensive sampling I could not find distinctive variegation in the other lineages, which had uni-coloured yellowish to brownish blades. Although 
preliminary studies have revealed possible morphological characters to distinguish the other three lineages (Chapter 7), the value of these characters is uncertain based on lacking information about the morphological variation within lineages. All lineages have been found to be restricted to certain areas around New Zealand with almost no overlap (Chapter 3). The sequence divergence between each lineage of $L$. variegata and its closest relative was of equal magnitude to the sequence divergence of other species (Table S 2.5). The smallest sequence divergence between species in Australasia was $1.9 \%$ between L. adamsiae and L. variegata-southern lineage (/S) and $2 \%$ between L. adamsiae and L. corrugata.

The data supported the split of L. nigrescens into two species as proposed by Tellier et al. (2009) (Fig. 2.2). Based on their finding of spatial separation I adopted their lineage abbreviations for the northern lineage $(\mathrm{N})$ and the Intermediate Area lineage (IA).

Samples identified as either L. vadosa or L. flavicans had only minor sequence differences (0.13\%; comparison of specimen A634 and C156), while there was major divergence of $L$. vadosa samples between different localities. For Example the level of differentiation between L. vadosa from the Falkland Islands, with or without the L. flavicans sample, and L. vadosa from the mainland was $0.69 \%$ and $0.72 \%$, respectively.

The placement of the root between L. trabeculata and L. nigrescens was not well supported (topology Fig. 2.2 vs. topology Fig. S 2.3). Root placement could affect phylogenetic relationships of the ingroup and evolutionary interpretations. Thus I tested whether the alignment effected topology (matrix-I vs. matrix-II), whether outgroup selection effected root position (e.g., due to long branch effect), 
and whether alternative rooting methods that do not require an outgroup (molecular clock rooting or mid-point rooting) changed tree topology. I also tested the fit of the ingroup alignment to three alternative topologies. Both supermatrices (matrix-I and matrix-II) had the same length but the ingroup alignments differed in 19 positions $(0.8 \%)$. The differences resulted in an ML topology for matrix-II where the root was between L. trabeculata and L. vadosa (TopoB, Fig. S 2.3). However, in neither tree, whether it was calculated based on matrix-I or matrix-II (Fig. 2.2 or Fig. S 2.3), was the root position supported and other ingroup relationships were not altered.

Additional outgroups that are more distantly related to both Lessonia and Ecklonia (Table S 2.5) were used to test root stability and tree topology with matrix-I [Eisenia bicyclis, Macrocystis pyrifera, Undaria pinnatifida (data not shown), and Laminaria ephemera (Fig. S 2.4)]. In all approaches, but the NJ-LogDet-calculation with Laminaria ephemera (Fig. S 2.4), the root position and tree topology was consistent to TopoA (Fig. 2.2); however, support of dichotomies was best when using only Ecklonia.

Clock-like evolution was rejected (Table S 2.6). Thus rooting under a molecular clock model should be treated with some caution. The two most divergent taxa (L. nigrescens/N and L. variegata/K, Table S 2.5) also evolved at different rates. However, phylogenetic trees rooted with a molecular clock assumption or at the midpoint resulted in a third topology with the root position between South America and Australasia (TopoC), defining two monophyletic groups. Within these clades, clock-like evolution was accepted (Table S 2.6).

The ingroup data of both datasets have been tested for their fit to the three alternative topologies (TopoA-C), revealing a best fit to TopoA (Table S 2.7). In 
TopoA, the South American Lessonia species form a paraphyletic assemblage with a group of Australasian species nested within it and L. nigrescens as sister to all other Lessonia. Recalculating the phylogenetic reconstruction with L. nigrescens as the only outgroup yielded highest support values for the relationships of the South American lineages (Fig. S 2.5). In a cascaded order L. trabeculata branches off first followed by L. flavicans. The Australasian Lessonia were monophyletic and strongly supported with a sister relationship to L. flavicans from South America. The branching order between Australasian taxa could not be well resolved. The only exception was a supported relationship between $L$. corrugata from Tasmania and $L$. adamsiae from The Snares (Fig. 2.2 and S 2.5).

The average amount of compositional heterogeneity was low (average difference in GC content $=0.3753 \%$, Table S 2.8) limiting causes of systematic error. The trees calculated under the three different calibration strategies showed all topology TopoB, which might be an artefact of using a clock assumption (even a relaxed clock) as phylogeny and divergence dates were coestimated under this approach (Drummond et al. 2006). Divergence times differ between all three calibrations, whereas strategy A is significantly different to strategy $\mathrm{C}$, the strategies $\mathrm{B}$ and $\mathrm{C}$ greatly overlap in their 95\% HPD (highest posterior density) of divergence times including each the mean of the respective other strategy (Fig. S 2.6). Using root heights as priors the mean divergence time between Ecklonia and Lessonia was found at the lower range of the priors [10 Mya or 16 Mya for strategy A (8.5-34 Mya) or B (15-19 Mya) respectively]. Using mutation rates as priors, the root height between Ecklonia and Lessonia was calculated at around 18 Mya. The mean of first speciation within Lessonia was calculated to have occurred 2.4 Mya, 3.9 Mya, or 4.6 
Mya according to calibration strategy $\mathrm{A}, \mathrm{B}$, and $\mathrm{C}$, respectively and radiation in Australasia started around 1.8 Mya, 2.9 Mya, or 3.4 Mya.

\subsection{Discussion}

We used Ecklonia as outgroup based on findings by Lane et al. (2006). However, Ecklonia shows great genetic distance to the ingroup and the last common ancestor was calculated to have lived 18 Mya, which is even higher than the divergence time estimated between families within the Laminariales. Tellier et al. (2009) estimated the divergence time between Laminaria digitata (Laminariaceae) and Alaria crassifolia (Alariaceae) between 10 and 15 Mya.

The closest relative of the tested outgroups has been Laminaria ephemera (HKY mean distance was 0.14 vs. 0.16 between Ecklonia and Lessonia), which supports findings by Lee et al. (2008) who catalogued northern and Southern Hemisphere brown algae while using the barcoding gene CO1. In contrast a relationship between L. ephemera and Lessonia was not found by Lane et al. (2006) who, investigating higher level relationships, included multiple markers and several species of Laminariaceae (including L. ephemera) and Lessoniaceae in their analysis to show that these two groups were clearly distinct. Gene tree incongruence is often explained by hybridisation or incomplete lineage sorting. In this case incomplete lineage sorting is likely to play a minor role as Lessonia and Laminaria have diverged a long time ago. Thus the close genetic distance between Lessonia and $L$. ephemera on one side and the distinction of Lessonia and L. ephemera into two different groups on the other side might be a signature of ancient hybridisation and reticulated evolution can not be excluded for Lessonia. Studies have shown that 
hybridisation may occure above species level within the Laminariales (Druehl et al. 2005 and references herein) but few studies have proposed ancient hybridisation as a mode of speciation within the Laminariales (Zhang et al. 2009). New methods have been proposed to detect hybridisation that can distinguish hybridisation from incomplete lineage sorting (Holland et al. 2008) or to assess the contribution of hybridisation to gene tree incongruence (Meng \& Kubatko 2009). Whether Lessonia is derived from ancient hybridisation is not known however it could influence the tree topology, thus I tested different combinations of outgroups, which all revealed a TopoA topology (L. nigrescens as sister to all other Lessonia) except for the ML-tree of the Ecklonia/L. ephemera combination, which had a TopoB topology ( $L$. nigrescens and L. trabeculata as sister to all other Lessonia). Rooting without outgroup (e.g., midpoint rooting or molecular clock rooting) is not optimal for the dataset but has resulted in a third topology (TopoC) with the root between South American and Australasian Lessonia. Regardless, all three topologies have been tested for their fit to the datasets, using a topology test method implemented in treefitter (Table S 2.7). Even though this method supported topology TopoA none of the other two topologies had statistical support for exclusion and thus the root position could not be determined with confidence.

The results suggest that Lessonia is a monophyletic lineage, as shown by Lane et al. (2006). While Lane et al. (2006) only analysed four species, I sampled all known species with multiple samples from disparate locations. The status of all species is supported with high support values except for $L$ variegata and $L$. nigrescens. 
We show for the first time four distinct and highly supported lineages that suggest non-monophyly for $L$. variegata. The sequence divergences between these lineages are greater than distances between some accepted species. This and the high support for each lineage, indicates that these four lineages should be regarded as four species, as they meet the criteria of phylogenetic species (Mishler \& Theriot 2000, Wheeler \& Platnick 2000). Similar findings were made by Tellier et al. (2009) in South America who likewise concluded species status for two L. nigrescens lineages, which is confirmed by my data. Further investigation of morphological characters to eventually describe and distinguish the lineages of L. variegata or alternatively show the cryptic nature of these lineages is needed (but see Chapter 7 for a preliminary analysis of four morphological characters).

Relationships at the backbone of the Australasian lineages had no support in any of the tree building methods. A NJ-LogDet analysis was added to verify these results as this method has been found to retrieve true relationships even if other methods fail (Jermiin et al. 2004). The accuracy of this method however depends on the difference in GC content between lineages and the relationship of internal to terminal branch length. As the data showed only minor difference in GC content (mean difference $=0.38 \%$ ), recovery of the correct phylogeny with the NJ-LogDet method was expected to be high (Jermiin et al. 2004). The failure of this method could be due to the internal branch lengths being less than $1 \%$ of the terminal branches. Given approximately 3 million years of evolution for the terminal branches (see dating analysis) then the radiation in Australasia would have taken place in a time frame of less then 30,000 years indicating a sudden radiation (Fig. 2.3). 
The results show a monophyletic origin of the Australasian flora. The only supported relationship among Australasian Lessonia was found between $L$. adamsiae, from The Snares ( $\left.48^{\circ} 01^{\prime} \mathrm{S} 166^{\circ} 32^{\prime} \mathrm{E}\right)$, and $L$. corrugata that is endemic to Tasmania. The placement of the Tasmanian species within New Zealand lineages might imply westward dispersal from The Snares to Tasmania from a last common ancestor between L. adamsiae and L. corrugata (Fig. 2.2 and S 2.5). However, additional analysis revealed possible hybrid-speciation of L. adamsiae derived from L. corrugata and L. variegata/S (southern lineage) ancestors (Chapter 3).

No major differences have been found between the samples from the Falkland Islands (0.18\%). One (A634) was previously used in other studies as L. ovata (=L. flavicans sensu Searles) (Lane et al. 2006) and the other two were identified by me as L. flavicans (=L. vadosa sensu Searles) based on the characteristic lacunae. The maximum difference $(0.79 \%)$ found between samples from the Falkland Islands and L. vadosa samples from Chile (Punta Arenas) represents rather the difference between distantly sampled populations of a widespread species than the difference between two species. However, it was the highest within group divergence found in this study. For comparison, the divergence within other widespread species was $0.75 \%$ and $0.53 \%$ for L. nigrescens/IA and $L$. trabeculata, respectively. I conclude that there is either not enough genetic differentiation between L. flavicans and L. ovata or the samples have been misidentified (i.e., lacunae are not an unambiguous identifying characteristic or the samples in GenBank are mislabelled (see Table 7.1). As there is not enough evidence for the former and no possibility to re-examine the sample (A634) collected as $L$. flavicans sensu Searles, I treat sample A634 as a wrongly identified L. flavicans 
specimen, as its haplotypes match those identified as L. flavicans from the Falkland Islands (Note: L. flavicans sensu Searles is different to L. flavicans in the way it is used here (see Chapter 6)).

The results suggest that the South American species form a paraphyletic grade with $L$. nigrescens in a sister relationship to all other Lessonia species and $L$. flavicans as a sister to a terminal Australasian clade. The basal placement of the three South American lineages might suggest an origin of the genus in South America, where three speciation events were followed by a single dispersal to Australasia and a subsequent Australasian radiation (after Sanmartin et al. 2007). An alternative hypothesis (based on a nested ancestral area interpretation as a consequence of unidirectional dispersal after Cook \& Crisp 2005) would suggest that New Zealand is the ancestral area. Dispersal events from New Zealand to South America, following the Antarctic Circumpolar Current, would have preceded the radiation in New Zealand and would have led to the formation of the South American species via repeated colonisation. It has been argued by Crisp \& Cook (2005) that phylogeographic interpretations that are based on tree topology alone are simplistic and not reliable. This topic needs further investigation.

Using a relaxed molecular clock assumption the resulting trees always resembled TopoB. My confidence in dating speciation events is higher for the Australasian grade than for the splitting events of the South American species, as, other than the former, the later change with the topology (TopoA vs. TopoB). With root heights as priors, the mean divergence time between Ecklonia and Lessonia was found at the lower range of the priors [10 Mya for strategy A (8.5-34 Mya) or 16 Mya for B (15-19 Mya); both strategies are based on within family splitting events]. 
Using mutation rates as priors, the root height (tmrca of Ecklonia and Lessonia) was calculated at around 18 Mya. This is at first sight higher than expected given that the mutation rates are based on the splitting time (between families) of 10 and 15 Mya (Tellier et al. 2009 using the divergence between Laminaria and Alaria). However, given the high genetic distance between Ecklonia and Lessonia, which is at a level with distances between families rather than within families (Table S 2.5) a root height at the upper range of the divergence spectrum, as in calibration strategy $\mathrm{C}$, seems to be more plausible. Therefore I further discuss the data based on hypotheses C alone (Fig. 2.3).

The Laminariales are believed to have evolved in the Pacific Ocean in the Northern Hemisphere as a response of climate deterioration (i.e., cooling) during the Tertiary, followed by antitropical dispersal in the late Pliocene (Estes \& Steinberg 1988 and 1989, Lüning \& tom Dieck 1990, and Lindberg 1991). This dispersal would have occurred during the first bipolar glaciation of the Cenozoic, which started 2.7 - 3 Mya (Shackleton et al. 1984). New evidence of synchronized bipolar cooling of the two Hemispheres since the Miocene might have allowed for antitropical dispersal of the coldwater adapted algae during episodic cooling cycles that started 20 My (DeConto et al. 2008) or even 35 My (Moran et al. 2006) earlier than previously thought. The differences are enormous and have the potential to challenge our knowledge about antitropical dispersal in brown algae. The rearrangement of genera within the Lessoniaceae (Lane et al. 2006) has led to a different global distribution pattern for this family, which is either bipolar (Ecklonia and Eisenia) or restricted to the Southern Hemisphere (Lessonia). Egregia is the only genus within this grouping that is solely found in the Northern Hemisphere but only 
associated weakly with the remaining genera (Lane et al. 2006). A Southern Hemisphere radiation of Lessoniaceae after an earlier antitropical split from a common ancestor can be an alternative hypothesis to a Northern Hemisphere radiation of all Laminariales as was proposed by Estes \& Steinberg (1988) and Lüning \& tom Dieck (1990). In any case the possibility of Lessonia (Southern Hemisphere only) having evolved through hybridisation between ancestors of Ecklonia (bipolar) and Laminaria (Northern Hemisphere only) would be hard to explain in a phylogeographic framework. However the timing of speciation through hybridisation might have been any time between 5 Mya (the first divergence event of Lessonia species) and 18 Mya (trmca of Ecklonia and Lessonia).

The data (calibration strategy C) suggests that a differentiation within Lessonia started less than 5 Mya (Fig. 2.3). This matches the beginning of the Pliocene when gradual cooling of the warmer Miocene had created a climate similar to today's El Nino events (Molnar \& Cane 2007, Bonham et al. 2009). Given the solely Southern Hemisphere distribution of Lessonia antitropical dispersal must have occurred latest in the late Miocene or early Pliocene, but might have been earlier depending on the theory of Lessoniaceae radiation. Biotic interchange of marine taxa during the early Pliocene with a north to south asymmetry was proposed earlier and summarized by Lindberg (1991).

The analysis further suggests that a sudden radiation of Lessonia species took place between 3 to 3.5 Mya. And even if Lessonia populations have been present in the Southern Hemisphere at least since the early Pliocene they might not have been widely distributed until their radiation. The increased availability of an alternative 
food source might have triggered adaptation of limpets and marine mammals to herbivory as described by Estes \& Steinberg (1988).

The timing of South American speciations should be treated with some caution as the lineages did not evolve clock-like (I used an uncorrelated log-normal distribution for the relaxed clock model to accommodate that) and as the timing also depends on the topology. Whereas a topology test favoured TopoA as the best fit to the data (Table S 2.7), the relaxed phylogenetics model in BEAST resulted in a TopoB tree. However, the calculations revealed a simultaneous speciation event to the radiation in Australasia between the South American L. nigrescens and $L$. trabeculata (3.4 Mya). The calculation of the splitting event between the two $L$. nigrescens lineages resulted a value between 1.367 - 2.840 Mya (with a mean of 2.066 Mya), which roughly coincides with the beginning of a worldwide unstable climate and the dawn of rapid oscillating glaciations at the Pliocene/Pleistocene boundary (Rapp 2009). However, my estimates are higher than the earlier proposed 0.250 - 1.698 Mya for the split between the two L. nigrescens lineages (Tellier et al. 2009). This can be explained the rooting differences between our surveys, as Tellier et al. (2009) used the same calibration I used in strategy C but L. corrugata as outgroup for the South American group (thus they assumed a TopoC topology).

In conclusion, my data shows that the South American species form a paraphyletic grade including a terminal monophyletic Australasian group. Four supported evolutionary lineages were detected in Lessonia variegata, indicating that this taxon consists of four species, which has not been reported before. This could have important implications for ecological management and conservation. Lessonia might have derived from ancient hybridisation between an early member of the 
Lessoniaceae and an ancestor of Laminaria ephemera. The first speciation took place in Lessonia 3.8 - 5.5 Mya marking the time of the latest possible antitropical dispersal from north to south; although earlier dispersal cannot be excluded. In Australasia, a rapid radiation started 3.5 Mya (2.9 - 4.1 Mya), leading to seven of the eight recent Australasian species. 


\subsection{Figure and Tables}
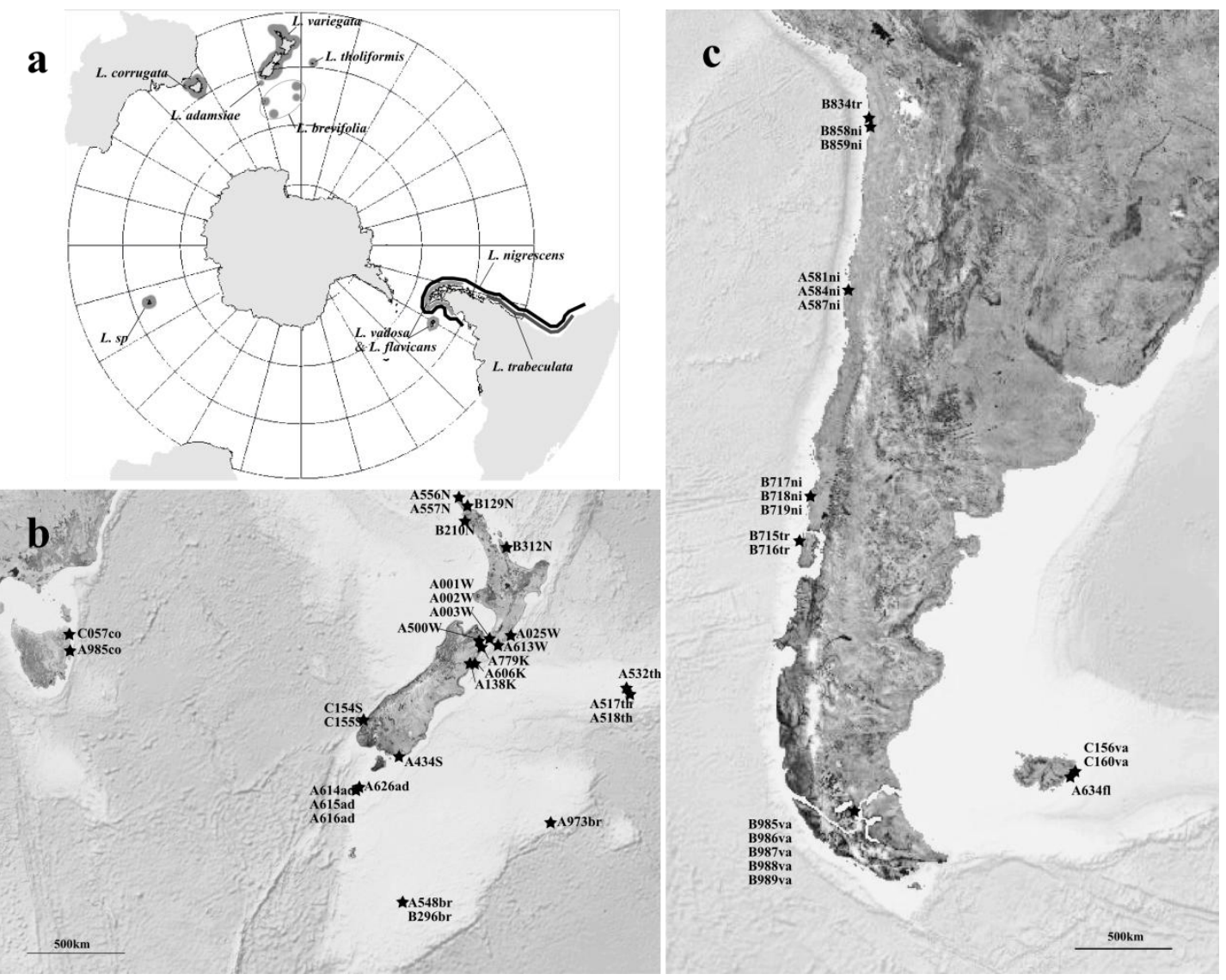

Fig. 2.1 Distribution and sample sites of Lessonia. a) Global distribution of Lessonia. b) sample sites in Australasia and c) in southern South America. Sample ID given as four ID numbers (see Table S 2.1 for exact locations) followed by species designation; $\mathrm{ad}=L$. adamsiae (The Snares), $\mathrm{br}=L$. brevifolia (Campbell Is. \& Antipodes), co = L. corrugata $($ Tasmania), $\mathrm{fl}=$ L. flavicans sensu Searles (Falkland), ni $=$ L. nigrescens $($ Chile), th $=$ L. tholiformis $($ Chatham Is.), $\operatorname{tr}=$ L. trabeculata $($ Chile), va $=$ L. flavicans (southern Chile \& Falkland), $\mathrm{K}=$ L. variegata/K (northeastern South Is.), $\mathrm{N}=L$. variegata/N (northern North Is.), $\mathrm{S}=$ L. variegata/S (southern South Is.), W = L. variegata/W (central New Zealand). 

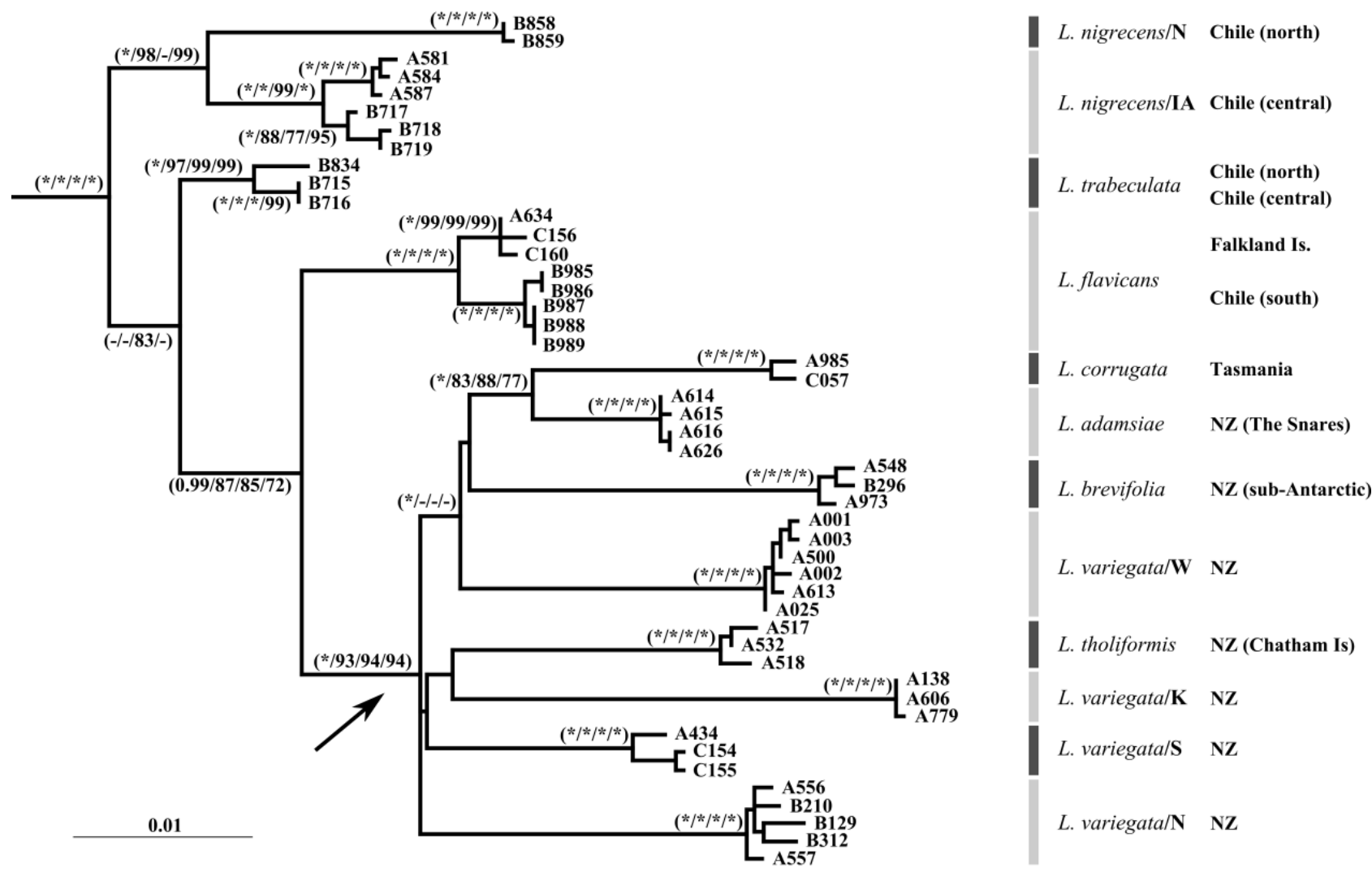

Fig. 2.2 Maximum-likelihood topology (TopoA) of the combined dataset (matrix-I). Scale bar = substitutions per site. Sample abbreviations according to sample ID's from Table S 2.1. Support values are Bayesian posterior probabilities, ML bootstraps, MP bootstraps, and NJ LogDet bootstraps, respectively. “*” represents 100\% support, whereas ““_“=< 0.95 posterior probability or $<70 \%$ bootstrap support. All methods resulted in a TopoA topology, however, only MP had support over $70 \%$. Abbreviations of L. nigrescens as in Tellier et al. (2009; N=northern lineage; IA=intermediate area). Arrow indicates the monophyletic Australasian group. Lessonia variegata is split into four lineages indicated with a lineage abbreviation after the back slash. $\mathrm{K}=\mathrm{Kaikoura}$ lineage, $\mathrm{N}=\mathrm{northern}$ lineage, $\mathrm{S}=$ southern lineage, and $\mathrm{W}=$ Wellington lineage. 


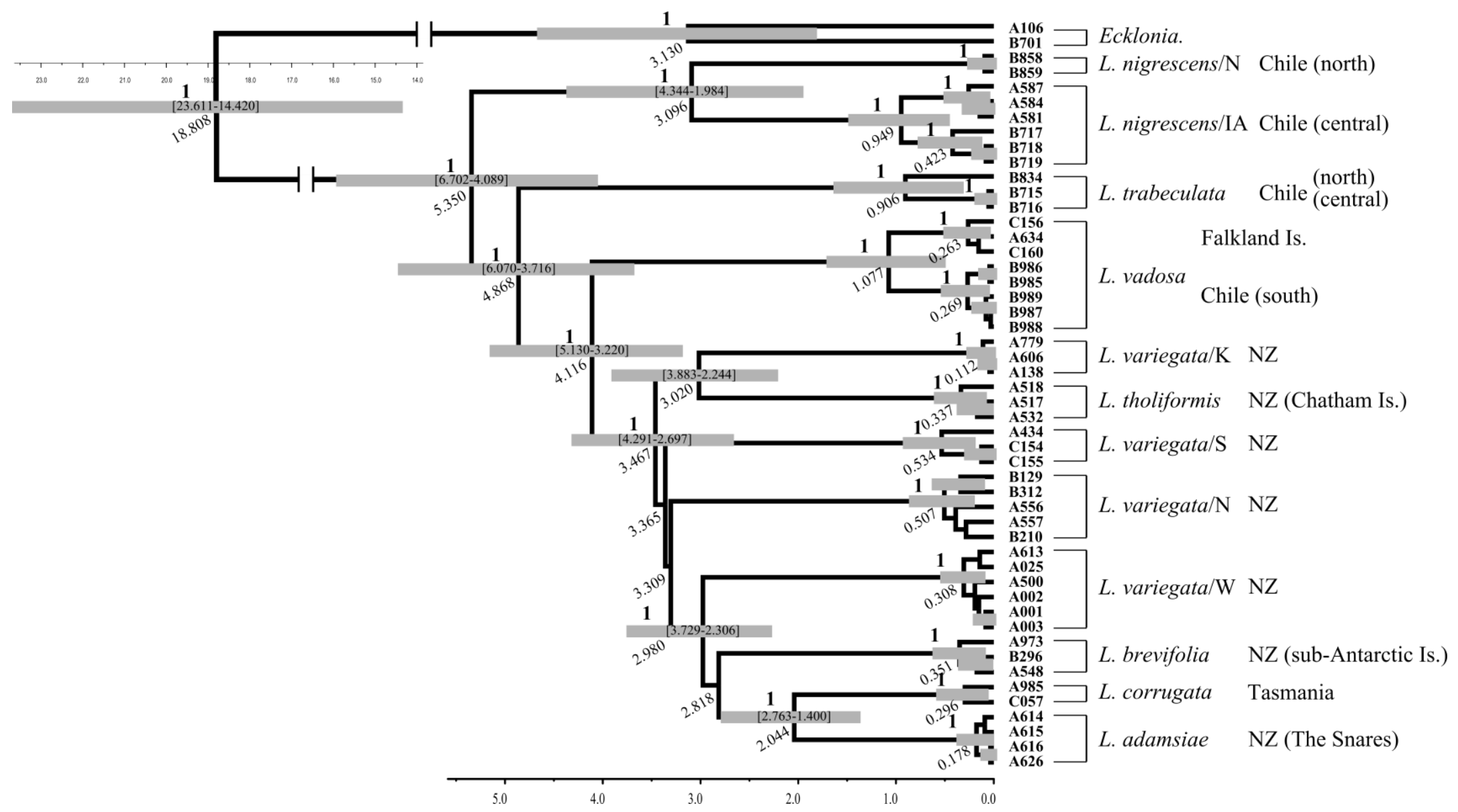

Fig. 2.3 Bayesian tree (TopoB) of a relaxed clock model of the combined dataset (matrix-I) following calibration strategy $\mathrm{C}$ with mutation rates as priors. Bars and numbers in brackets showing $95 \%$ of the highest posterior density of the node height (indicating the tmrca of adjacent branches); mean node age is given as a vertical number; support values are posterior probabilities. Scale axes in Mya. Figure shows speciation within Lessonia ( $<5$ Mya) and a sudden radiation in the Australasian grade (ca. 3.5 - 3 Mya). 
Table 2.1 Marker and dataset characteristic (matrix-I). Table shows the length of the marker regions, the mixture of variability in the markers used (variable sites (v) and parsimony informative sites (p.i.) in ingroup comparison), and amount of saturation (including outgroup). $\mathrm{mt}=$ mitochondrial, $\mathrm{cl}=\mathrm{chloroplast}$, nuc $=$ nuclear, bp $=$ base pair. ${ }^{1}$ Test of variability after Koblmueller et al. 2006 (< $10 \%$ low, $10-20 \%$ high, > 20\% hyper). ${ }^{2}$ Saturation test after Verbruggen \& Theriot 2008 (see also Fig. S 2.2 ag). ${ }^{3}$ for p.i. only.

\begin{tabular}{|c|c|c|c|c|c|c|c|c|c|}
\hline marker & DNA & bp & $\mathrm{v}(\mathrm{bp})$ & $\mathrm{v}(\%)$ & p.i. (bp) & p.i. (\%) & variability $^{1}$ & \multicolumn{2}{|c|}{ saturation as slope ${ }^{2}$} \\
\hline atp8-Sp & $\mathrm{mt}$ & 153 & 45 & 29.4 & 37 & 24.2 & hyper & 0.8501 & weak \\
\hline trnW-Sp & $\mathrm{mt}$ & 227 & 56 & 24.7 & 52 & 22.9 & hyper & 0.8182 & weak \\
\hline nd6-gene & $\mathrm{mt}$ & 860 & 126 & 14.7 & 115 & 13.4 & high & 0.9086 & weak \\
\hline $1^{\mathrm{st}}$ & & 287 & 32 & 11.1 & 28 & 9.8 & high $\left(\right.$ low $\left.{ }^{3}\right)$ & 0.9381 & weak \\
\hline $2^{\text {nd }}$ & & 287 & 17 & 5.9 & 15 & 5.2 & low & 0.9691 & weak \\
\hline $3^{\text {rd }}$ & & 286 & 77 & 26.9 & 72 & 25.2 & hyper & 0.7209 & intermediate \\
\hline rbc-Sp & $\mathrm{cl}$ & 331 & 12 & 3.6 & 11 & 3.3 & low & 0.9539 & weak \\
\hline ITS & nuc & 709 & 95 & 13.4 & 86 & 12.1 & high & 0.9388 & weak \\
\hline ITS1 & & 314 & 69 & 22.0 & 64 & 20.4 & hyper & 0.9199 & weak \\
\hline $5.8 \mathrm{~S}$ & & 160 & 1 & 0.6 & 1 & 0.6 & very low & - & - \\
\hline ITS2 & & 235 & 25 & 10.6 & 21 & 8.9 & high $\left(\right.$ low $\left.^{3}\right)$ & 0.8722 & weak \\
\hline combined & & 2280 & 334 & 14.6 & 301 & 13.2 & high & - & - \\
\hline
\end{tabular}




\subsection{References}

Agardh, J. G. 1878. De Algis Novae Zelandiae marinis. In Supplementum Florae Hookerianae. Acta Universitatis Lundensis: Lunds Universitets Årsskrift Volume 14. Fr. Berlings boktr., Lund, pp. 1-32.

Asensi, A. \& de Reviers, B. 2009. Illustrated catalogue of types of species historically assigned to Lessonia (Laminariales, Phaeophyceae) preserved at PC, including a taxonomic study of three South-American species with a description of $L$. searlesiana sp. nov. and a new lectotypification of $L$. flavicans. Cryptogam. Algol. 30:209-49.

Barrales, H. \& Lobban, C. S. 1975. The comparative ecology of Macrocystis pyrifera, with emphasis on the forest of Chubut, Argentina. J. Ecol. 63:65775.

Bonfield, J. K., Smith, K. F. \& Staden, R. 1995. A new DNA sequence assembly program. Nucleic Acids Res. 23:4992-99. [http://www.mrclmb.cam.ac.uk/pubseq/index.html]

Bonham, S. G., Haywood, A. M., Lunt, D. J., Collins, M. \& Salzmann, U. 2009. El Niño-Southern Oscillation, Pliocene climate and equifinality. Phil. Trans. $R$. Soc. A 367:127-56.

Castresana, J. 2000. Selection of conserved blocks from multiple alignments for their use in phylogenetic analysis. Mol. Biol. Evol. 17:540-52. 
Cook, L. G. \& Crisp, M. D. 2005. Directional asymmetry of long-distance dispersal and colonization could mislead reconstructions of biogeography. J. Biogeogr. $32: 741-54$

Crisp, M. D. \& Cook, L. G. 2005. Do early branching lineages signify ancestral traits? Trends Ecol. Evol. 20:122-28.

Cunningham, C. W. 1997. Can three incongruence tests predict when data should be combined? Mol. Biol. Evol. 14:733-40.

DeConto, R. M., Pollard, D., Wilson, P. A., Palike, H., Lear, C. H. \& Pagani, M. 2008. Thresholds for Cenozoic bipolar glaciation. Nature 455:652-57.

Delepine, R. 1963. Observations sur la végétation marine des îles Australes Françaises. Société Phycologique de France 8:9-10.

Demes, K., Graham, M. H. \& Suskiewicz, T. S. 2009. Phenotypic plasticity reconciles incongruous molecular and morphological taxonomies: giant kelp, Macrocystis (Laminariales, Phaeophyceae), is a monospecific genus. $J$. Phycol. 45:1266-69.

Druehl, L. D., Collins, J. D., Lane, C. E. \& Saunders, G. W. 2005. An evaluation of methods used to assess intergeneric hybridization in kelp using Pacific Laminariales (Phaeophyceae). J. Phycol. 41:250-62.

Druehl, L. D. \& Saunders, G. W. 1992. Molecular explorations in kelp evolution. Prog. Phycol. Res. 8:47-83.

Drummond, A. J. \& Rambaut, A. 2007. BEAST: Bayesian evolutionary analysis by sampling trees. BMC Evol. Biol., 214 pp. 
Drummond, A. J., Ho, S. Y. W., Phillips, M. J. \& Rambaut, A. 2006. Relaxed phylogenetics and dating with confidence. PLoS Biol. 4:699-710.

Edding, M. E., Fonk, E. A. \& Macchiavello, J. E. 1994. Lessonia. In: Akatsuka, I. [Ed.] Biology of Economic Algae. SPB Academic Pubishing, The Hague, pp. 407-46.

Edgar, R. C. 2004. MUSCLE: multiple sequence alignment with high accuracy and high throughput. Nucleic Acids Res. 32:1792-97.

Estes, J. A. \& Steinberg, P. D. 1988. Predation, herbivory, and kelp evolution. Paleobiology 14:19-36.

Estes, J. A. \& Steinberg, P. D. 1989. Response to Domning. Paleobiology 15:57-60.

Ewing, B. \& Green, P. 1998. Base-calling of automated sequencer traces using phred. II. Error probabilities. Genome Res. 8:186-94. [http://bozeman.genome.washington.edu/phrap.docs/phred.html]

Farris, J. S., Källersjö, M., Kluge, A. G. \& Bult, C. 1994. Testing significance of incongruence. Cladistics 10:315-19.

Faugeron, S., Martinez, E. A., Correa, J. A. \& Billot, C. 2005. Long-term copper mine waste disposal in northern Chile associated with gene flow disruption of the intertidal kelp Lessonia nigrescens. Mar. Ecol. Prog. Ser. 288:129-40.

Felsenstein, J. 1985. Confidence limits on phylogenies: an approach using the bootstrap. Evolution 39:783-91. 
Fernández, E., Córdova, C. \& Tarazona, J. 1999. Condiciones de la pradera submareal de Lessonia trabeculata en la Isla Independencia durante El Niño 1997-98. In: Tarazona, J. \& Castillo, E. [Eds.] El Niño 1997-98 y su impacto en los ecosistemas marino y terrestre. Facultad de Ciencias Biológicas UNMSM Lima, pp. 47-59.

Guindon, S. \& Gascuel, O. 2003. A simple, fast, and accurate algorithm to estimate large phylogenies by maximum likelihood. Syst. Biol. 52:696-704.

Hall, T. A. 1999. BioEdit: a user-friendly biological sequence alignment editor and analysis program for Windows 95/98/NT. Nucl. Acids. Symp. Ser. 7.0.9.0 ed., pp. 95-98.

Hasegawa, M., Kishino, H. \& Yano, T. A. 1985. Dating of the human-ape splitting by a molecular clock of mitochondrial DNA. J. Mol. Evol. 22:160-74.

Hay, C. H. 1987. Lessonia adamsiae sp. nov. (Phaeophyta, Laminariales) from the Snares Islands, New-Zealand. N. Z. J. Bot. 25:295-308.

Hay, C. H. 1989. Lessonia tholiformis sp. nov. (Phaeophyta, Laminariales) from the Chatham Islands, New-Zealand. N. Z. J. Bot. 27:461-69.

Hoarau, G., Coyer, J. A., Veldsink, J. H., Stam, W. T. \& Olsen, J. L. 2007. Glacial refugia and recolonization pathways in the brown seaweed Fucus serratus. Mol. Ecol. 16:3606-16.

Holland, B. R., Benthin, S., Lockhart, P. J., Moulton, V. \& Huber, K. T. 2008. Using supernetworks to distinguish hybridization from lineage-sorting. BMC Evol. Biol. 8: Article No.: 202. 
Jermiin, L. S., Ho, S. Y. W., Ababneh, F., Robinson, J. \& Larkum, A. W. D. 2004. The biasing effect of compositional heterogeneity on phylogenetic estimates might be underestimated. Syst. Biol. 53:638-43.

Jobb, G. 2008. TREEFINDER version of October 2008. Distributed by the author at www.treefinder.de. Munich, Germany.

Koblmüller, S., Sturmbauer, C., Verheyen, E., Meyer, A., \& Salzburger, W. 2006. Mitochondrial phylogeny and phylogeography of East African squeaker catfishes (Siluriformes: Synodontis). BMC Evolutionary Biology. 6: Article 49.

Lane, C. E., Lindstrom, S. C. \& Saunders, G. W. 2007. A molecular assessment of northeast Pacific Alaria species (Laminariales, Phaeophyceae) with reference to the utility of DNA barcoding. Mol. Phylogenet. Evol. 44:634-48.

Lane, C. E., Mayes, C., Druehl, L. D. \& Saunders, G. W. 2006. A multi-gene molecular investigation of the kelp (Laminariales, Phaeophyceae) supports substantial taxonomic re-organization. J. Phycol. 42:493-512.

Lee, S-Y., Jung, M-Y., Kim, J. H., Kang, S-H., chung, H. \& Choi, H-G. DNA barcoding of brown algae around two Korean stations in the Antarctic and the Arctic. Poster session presented at: Algae in a changing world. $\mathrm{V}^{\text {th }}$ Asian Pacific Phycological Forum; 2008 November 10-14; Wellington, New Zealand.

Lindberg, D. R. 1991. Marine biotic interchange between the northern and southern hemispheres. Paleobiology 17:308-24. 
Lucas, A. H. S. 1931. Notes on Australian marine algae. VI. Descriptions of six new species. Proc. Linn. Soc. N. S. W. 56:407-11.

Luening, K. \& tom Dieck, I. 1990. The distribution and evolution of the Laminariales: North Pacific - Atlantic relationships. In: Garbary, D. J. \& South, G. R. [Eds.] Evolutionary biogeography of the marine algae of the North Atlantic. Springer, Berlin. pp. 187-204.

Macaya, E. C. \& Zuccarello, G. C. 2010. DNA barcoding and genetic divergence in the giant kelp Macrocystic (Laminariales). J. Phycol. 46:736-42.

Martinez, E. A. 1999. Latitudinal differences in thermal tolerance among microscopic sporophytes of the kelp Lessonia nigrescens (Phaeophyta: Laminariales). Pac. Sci. 53:74-81.

McDevit, D. C. \& Saunders, G. W. 2009. On the utility of DNA barcoding for species differentiation among brown macroalgae (Phaeophyceae) including a novel extraction protocol. Phycol. Res. 57:131-41.

Meng, C. \& Kubatko, L. S. 2009. Detecting hybrid speciation in the presence of incomplete lineage sorting using gene tree incongruence: A model. Theor. Popul. Biol. 75:35-45.

Mishler, B. D. \& Theriot, E. C. 2000. The phylogenetic species concept (sensu Mishler and Theriot): Monophyly, apomorphy, and phylogenetic species concepts. In: White, W. B. \& Meier, R. [Eds.] Species Concepts and Phylogenetic Theory: A Debate. Columbia University Press, New York, pp. 44-54. 
Molnar, P. \& Cane, M. A. 2007. Early Pliocene (pre-Ice Age) El Nino-like global climate: which El Nino? Geosphere 3:337-65.

Moran, K., Backman, J., Brinkhuis, H., Clemens, S. C., Cronin, T., Dickens, G. R., Eynaud, F., Gattacceca, J., Jakobsson, M., Jordan, R. W., Kaminski, M., King, J., Koc, N., Krylov, A., Martinez, N., Matthiessen, J., McInroy, D., Moore, T. C., Onodera, J., O'Regan, M., Palike, H., Rea, B., Rio, D., Sakamoto, T., Smith, D. C., Stein, R., St John, K., Suto, I., Suzuki, N., Takahashi, K., Watanabe, M., Yamamoto, M., Farrell, J., Frank, M., Kubik, P., Jokat, W. \& Kristoffersen, Y. 2006. The Cenozoic palaeoenvironment of the Arctic Ocean. Nature 441:601-05.

Papenfuss, G. F. 1964. Catalogue and bibliography of Antarctic and Sub-Antarctic benthic marine algae. In: Lee, M. O. [Ed.] Biology of the Antarctic seas. American Geophysical Union, Washington, pp. 1-76.

Peters, A. F. \& Ramirez, M. E. 2001. Molecular phylogeny of small brown algae, with special reference to the systematic position of Caepidium antarcticum (Adenocystaceae, Ectocarpales). Cryptogam. Algol. 22:187-200.

Phillips, N., Burrowes, R., Rousseau, F., de Reviers, B. \& Saunders, G. W. 2008. Resolving evolutionary relationships among the brown algae using chloroplast and muclear genes. J. Phycol. 44:394-405.

Posada, D. \& Crandall, K. A. 1998. Modeltest: testing the model of DNA substitution. Bioinformatics 14:817-18. 
Rambaut, A. \& Drummond, A. J. 2007. Tracer v.1.4 Available from http://beast.bio.ed.ac.uk/Tracer.

Rapp, D. 2009. Ice Ages and Interglacials - Measurements, Interpretation and Models. Springer, Berlin, 263 pp.

Ronquist, F. \& Huelsenbeck, J. P. 2003. MRBAYES 3: Bayesian phylogenetic inference under mixed models. Bioinformatics 19:1572-74.

Sanmartin, I., Wanntorp, L. \& Winkworth, R. C. 2007. West Wind Drift revisited: testing for directional dispersal in the Southern Hemisphere using eventbased tree fitting. J. Biogeogr. 34:398-416.

Sasaki, H. \& Kawai, H. 2007. Taxonomic revision of the genus Chorda (Chordaceae, Laminariales) on the basis of sporophyte anatomy and molecular phylogeny. Phycologia 46:10-21.

Saunders, G. W. \& Druehl, L. D. 1992. Nucleotide sequences of the small-subunit ribosomal RNA genes from selected Laminariales (Phaeophyta): Implications for Kelp evolution. J. Phycol. 28:544-49.

Searles, R. B. 1978. Genus Lessonia Bory (Phaeophyta, Laminariales) in Southern Chile and Argentina. Br. Phycol. J. 13:361-81.

Setchell, W. A. \& Gardner, N. L. 1925. The Marine Algae of the Pacific coast of North America. University of California Press, Berkley, 898 pp.

Shackleton, N. J., Backman, J., Zimmerman, H., Kent, D. V., Hall, M. A., Roberts, D. G., Schnitker, D., Baldauf, J. G., Desprairies, A., Homrighausen, R., Huddlestun, P., Keene, J. B., Kaltenback, A. J., Krumsiek, K. A. O., Morton, 
A. C., Murray, J. W. \& Westbergsmith, J. 1984. Oxygen isotope calibration of the onset of ice-rafting and history of glatiation in the north-atlantic region. Nature 307:620-23.

Staden, R., Judge, D. P. \& Bonfield, J. K. 2002. Sequence Assembly and Finishing Methods. In: Andreas D. Baxevanis, B. F. F. O. [Ed.] Bioinformatics (Second Edition). pp. 303-22. [http://staden.sourceforge.net/]

Stam, W. T., Bot, P. V. M., Boele-Bos, S. A., van Rooij, J. M. \& van den Hoek, C. 1988. Single-copy DNA-DNA hybridizations among five species of Laminaria (Phaeophyceae): phylogenetic and biogeographic implications. Helgol. Meeresunters. 42:251-67.

Swofford, D. L. 2002. PAUP* Phylogenetic Analysis Using Parsimony (*and other Methods). Sinauer Associates, Sunderland, MA.

Tai, V., Lindstrom, S. C. \& Saunders, G. W. 2001. Phylogeny of the Dumontiaceae (Gigartinales, Rhodophyta) and associated families based on SSU rDNA and internal transcribed spacer sequence data. J. Phycol. 37:184-96.

Tamura, K., Dudley, J., Nei, M. \& Kumar, S. 2007. MEGA4: Molecular Evolutionary Genetics Analysis (MEGA) Software Version 4.0. Mol. Biol. Evol., pp. 1596-99.

Tamura, K. \& Kumar, S. 2002. Evolutionary distance estimation under heterogeneous substitution pattern among lineages. Mol. Biol. Evol. 19:172736. 
Tellier, F., Meynard, A. P., Correa, J. A., Faugeron, S. \& Valero, M. 2009. Phylogeographic analyses of the 30 degrees S south-east Pacific biogeographic transition zone establish the occurrence of a sharp genetic discontinuity in the kelp Lessonia nigrescens: Vicariance or parapatry? Mol. Phylogenet. Evol. 53:679-93.

Thompson, J. D., Higgins, D. G. \& Gibson, T. J. 1994. CLUSTAL-W - Improving the sensitivity of progressive multiple sequence alignment through sequence weighting, position-specific gap penalties and weight matrix choice. Nucleic Acids Res., pp. 4673-80.

Uwai, S., Arai, S., Morita, T. \& Kawai, H. 2007. Genetic distinctness and phylogenetic relationships among Undaria species (Laminariales, Phaeophyceae) based on mitochondrial cox3 gene sequences. Phycol. Res. $55: 263-71$

Verbruggen, H. \& Theriot, E. C. 2008. Building trees of algae: some advances in phylogenetic and evolutionary analysis. Eur. J. Phycol. 43:229-52.

Voisin, M., Engel, C. R. \& Viard, F. 2005. Differential shuffling of native genetic diversity across introduced regions in a brown alga: Aquaculture vs. maritime traffic effects. Proc. Natl. Acad. Sci. U. S. A. 102:5432-37.

Wheeler, Q. D. \& Platnick, N. I. 2000. The Phylogenetic Species Concept (sensu Wheeler and Platnick). In: Wheeler, Q. D. \& Meier, R. [Eds.] Species Concepts and Phylogenetic Theory: A Debate. Columbia University Press, New York, pp. 55-69. 
Zhang, Z., Wang, R., Meng, X., Wang, X. \& Li, X. 2009. Phylogenetic analysis of members of the order Laminariales based on rbcL genes and 5.8S rRNA genes. 3rd International Conference on Bioinformatics and Biomedical Engineering, 2009. ICBBE 2009. Beijing.

Zuccarello, G. C. \& Lokhorst, G. M. 2005. Molecular phylogeny of the genus Tribonema (Xanthophyceae) using rbcL gene sequence data: monophyly of morphologically simple algal species. Phycologia 44:384-92. 


\subsection{Supplementary}

\subsubsection{Figures}

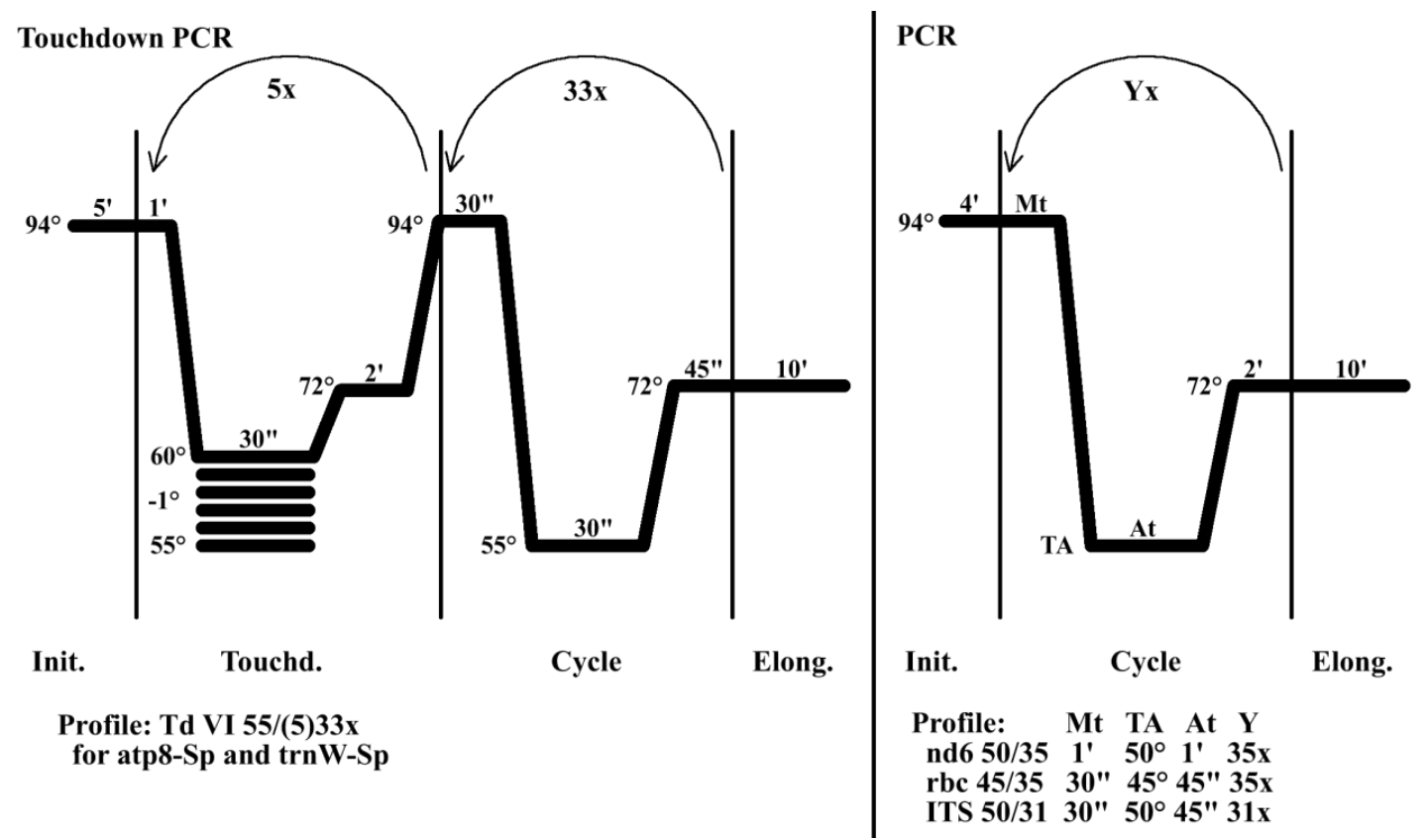

Fig. S 2.1 PCR profiles for the fife markers used. Touchdown PCR was used for atp8-Sp and trnWSp; a simple PCR profile was used for nd6-gene, rbc-Sp, and ITS. 

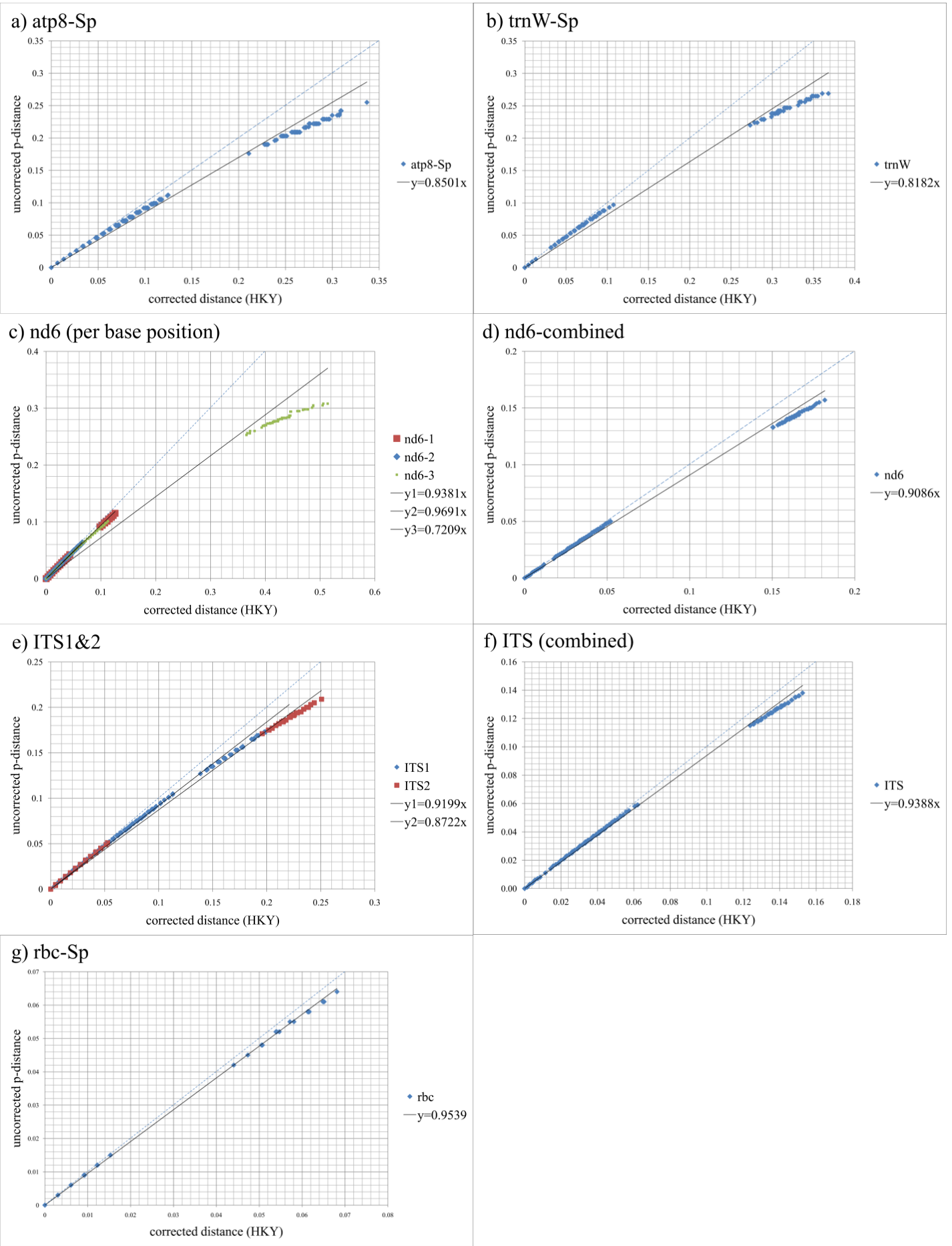

Fig. S 2.2 Slope of saturation curves for detecting saturation within a marker region. Dashed line indicates the no saturation slope (i.e., uncorrected distances equal corrected distances). All markers, except the $3^{\text {rd }}$ position of the nd6-gene, are slow evolving and weak saturated. The $3^{\text {rd }}$ codon position of the nd6-gene is medium fast evolving with intermediate saturation (after Verbruggen and Theriot 2008) (see also Table 1). 


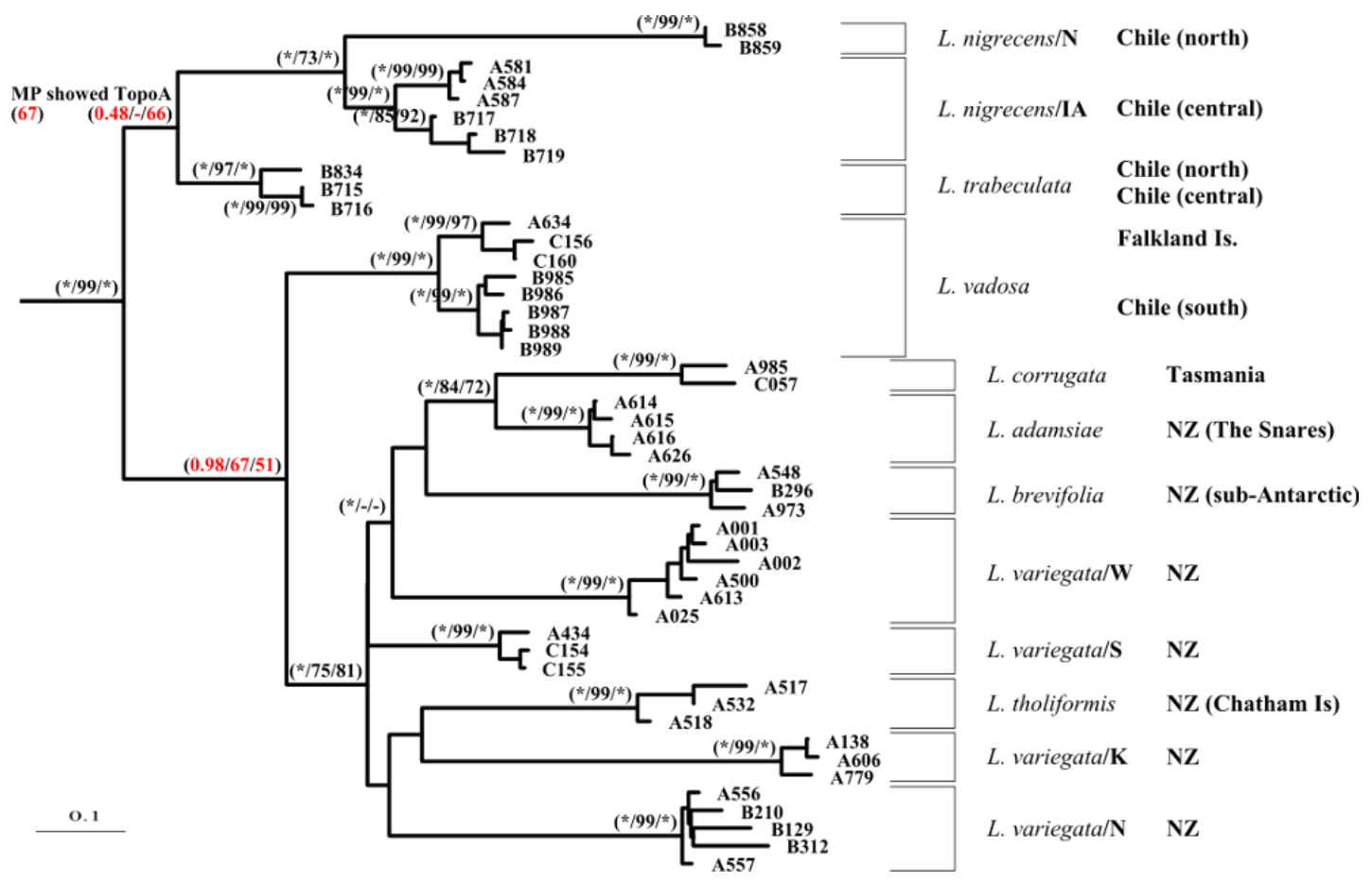

Fig. S 2.3 Bayesian topology (TopoB) using the second alignment (matrix-II). Scale bar = substitutions per site. Sample abbreviations according to sample ID's from Table S1. Support values are Bayesian posterior probabilities, MP bootstraps, and NJ LogDet bootstraps, respectively. “*” represents $100 \%$ support, whereas “-“ $=<0.95$ posterior probability or $<70 \%$ bootstrap support, except for the red numbers that support the root position. Only Bayesian and NJ resulted in a TopoB topology, however, without support. The MP-tree had an unsupported TopoA topology.

Abbreviations as in Fig. 2. 


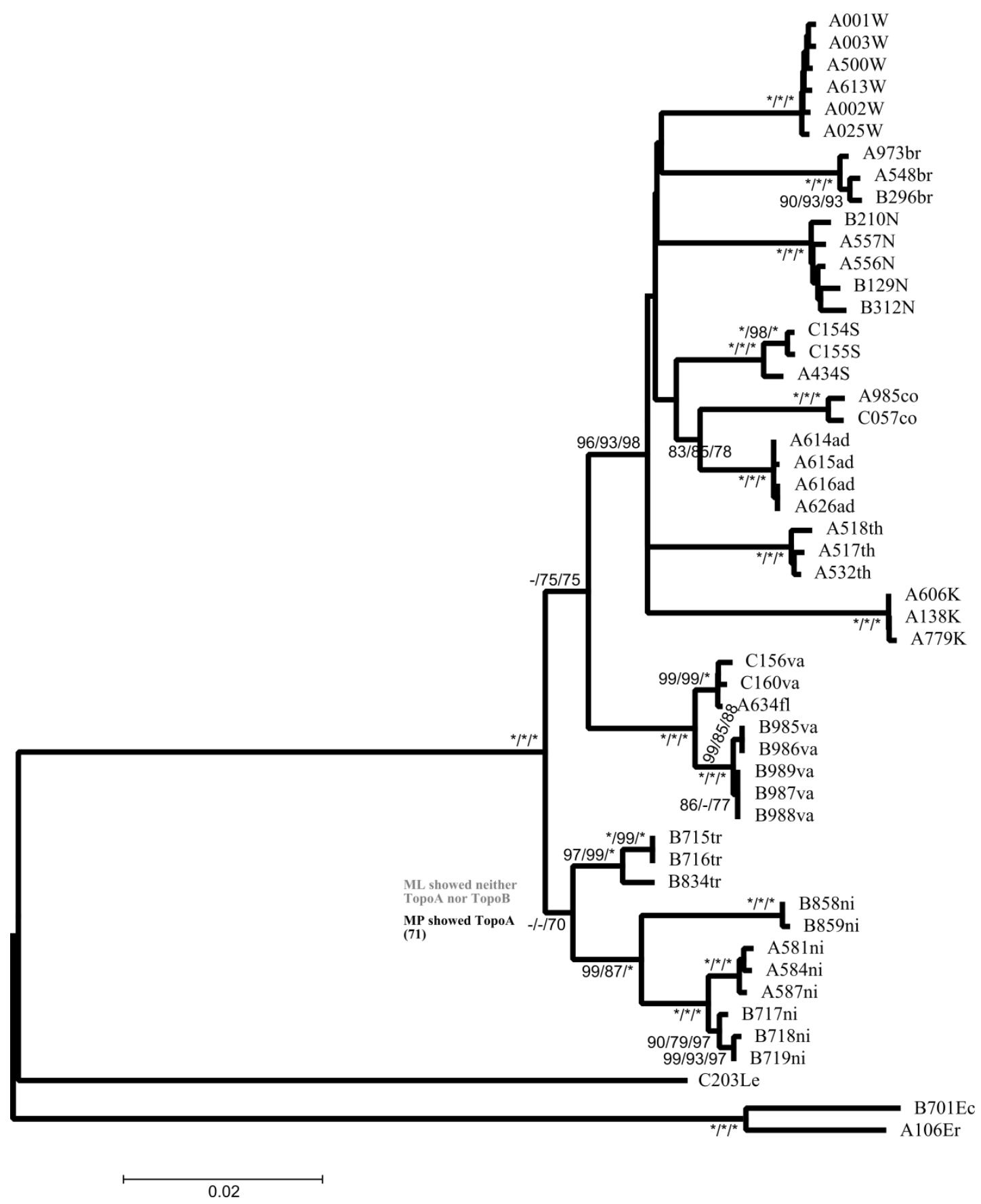

Fig. S 2.4 NJ-LogDet topology (TopoB) of the combined dataset (matrix-I) with Laminaria ephemera included to the outgroup. Scale bar = substitutions per site. Sample abbreviations according to sample ID's from Table S1 and as described in Fig. 2. Support values are ML bootstraps, MP bootstraps, and NJ LogDet bootstraps, respectively. “*” represents $100 \%$ support, whereas “_“ $=<0.95$ posterior probability or $<70 \%$ bootstrap support. 


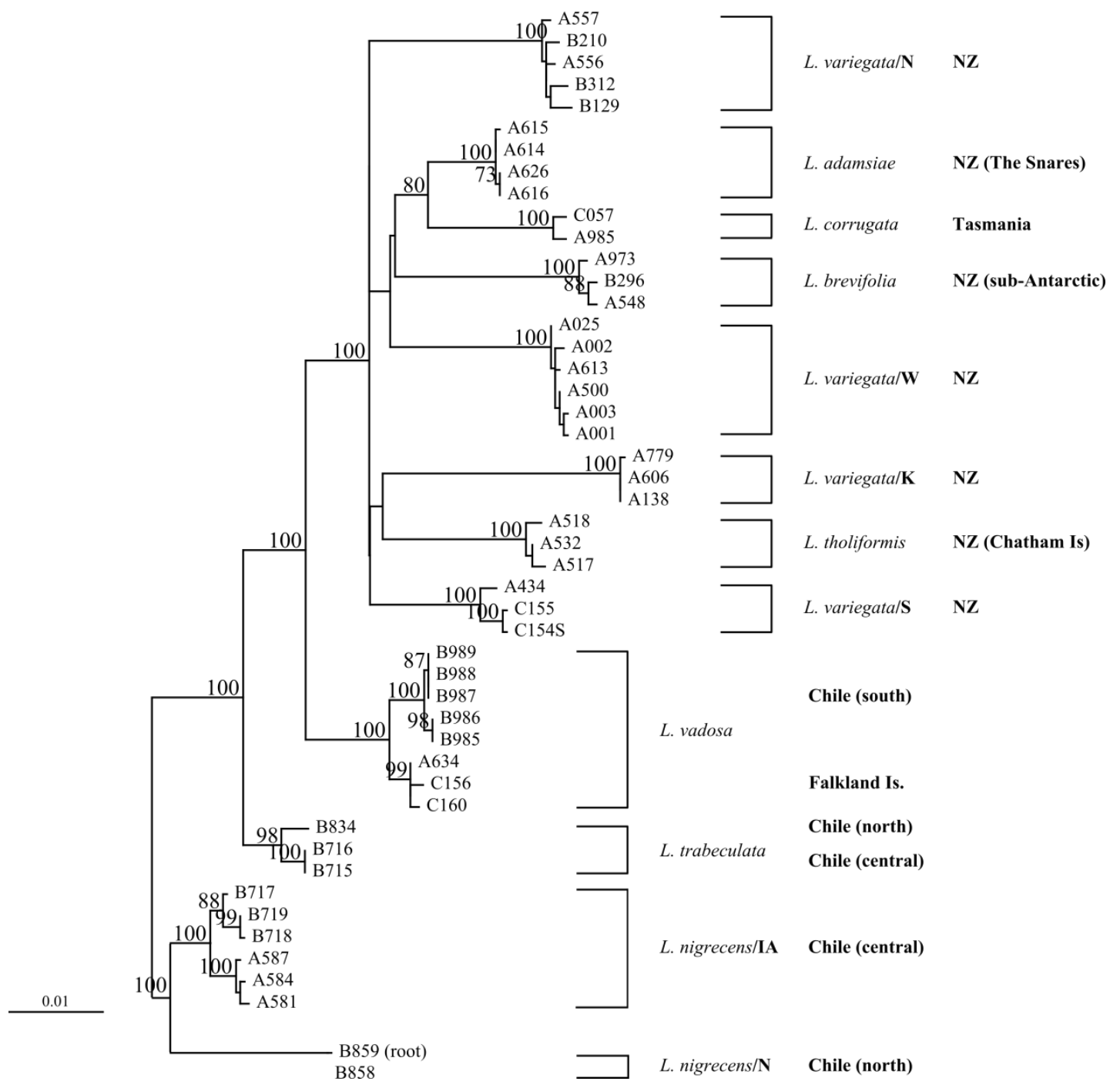

Fig. S 2.5 ML tree without outgroup and rooted on L. nigrescens (B859). 


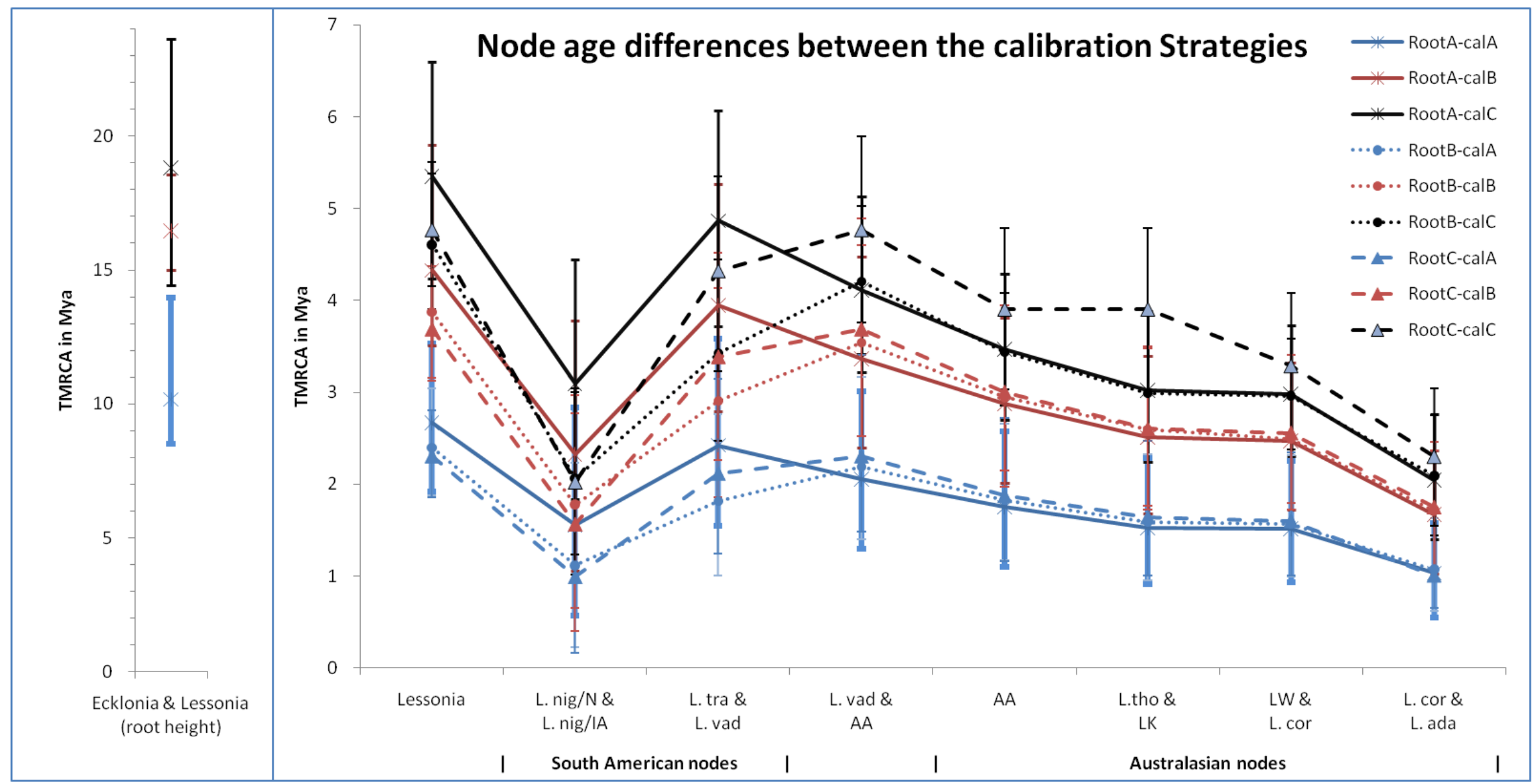

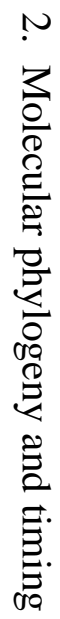

Fig. S 2.6 Node age differences between root positions and calibration strategies. Notice that the y-axis for the root height is different to the y-axis for the ingroup node heights. Graphic showes that the node heights within Australasia are nearly independent from the root position (exept for root $\mathrm{C}$ cal-C) but vary if a different calibration strategy is used. Solid line root A, dotted line rootB, dashed line root C. Blue calibration strategy A, brown calibration strategy B, black calibration strategy C. 


\subsubsection{Tables}

Table S 2.1 Species identification, sample ID, location with geographic information (if available), and GenBank accession numbers. Collector if not authors in parentheses. indicates that exact GPS location of the sampled population was not recorded but retrieved from Google Earth ver. 5.1. The $L$. flavicans specimen (A635) was also used in a previous study by Lane et al. (2006); however I suspect it to be misidentified L. vadosa specimen (see text).

\begin{tabular}{|c|c|c|c|c|}
\hline \multirow{2}{*}{$\begin{array}{l}\text { Species } \\
\text { E. cava }\end{array}$} & \multirow{2}{*}{$\begin{array}{l}\text { Sample ID } \\
\text { B701 }\end{array}$} & Location (collectors if not authors) & \multicolumn{2}{|c|}{$\begin{array}{l}\text { GenBank accession } \\
\text { numbers }\end{array}$} \\
\hline & & \multirow{5}{*}{$\begin{array}{l}\text { Lat: } \\
\text { Long: } \\
\text { (C. Lane) }\end{array}$} & atp8-Sp: & GU593723 \\
\hline & & & trnW-Sp: & GU593923 \\
\hline & & & nd6: & GU593823 \\
\hline & & & rbc-Sp: & GU593873 \\
\hline & & & ITS: & GU593773 \\
\hline \multirow[t]{5}{*}{ E. radiata } & \multirow[t]{5}{*}{ A106 } & \multirow[t]{2}{*}{ Paia Point, Kaikoura, NZ } & atp8-Sp: & GU593724 \\
\hline & & & trnW-Sp: & GU593924 \\
\hline & & Lat: $42^{\circ} 29^{\prime} 22.43^{\prime \prime} \mathrm{S}$ & nd6: & GU593824 \\
\hline & & \multirow[t]{2}{*}{ Long: $173^{\circ} 31^{\prime} 27.05^{\prime \prime} \mathrm{E}$} & rbc-Sp: & GU593874 \\
\hline & & & ITS: & GU593774 \\
\hline \multirow[t]{5}{*}{ L. adamsiae } & \multirow[t]{5}{*}{ A614 } & \multirow[t]{2}{*}{ Tahi, The Snares, NZ } & atp8-Sp: & GU593749 \\
\hline & & & trnW-Sp: & GU593949 \\
\hline & & Lat: $\sim 48^{\circ} 03^{\prime} 42.42^{\prime \prime} \mathrm{S}$ & nd6: & GU593849 \\
\hline & & \multirow{2}{*}{$\begin{array}{l}\text { Long: } 166^{\circ} 30^{\prime} 59.99 " \mathrm{E} \\
\text { (L. Hunt) }\end{array}$} & rbc-Sp: & GU593899 \\
\hline & & & ITS: & GU593799 \\
\hline \multirow[t]{5}{*}{ L. adamsiae } & \multirow[t]{5}{*}{ A615 } & \multirow[t]{2}{*}{ Tahi, The Snares, NZ } & atp8-Sp: & GU593750 \\
\hline & & & $\operatorname{trnW}-\mathrm{Sp}:$ & GU593950 \\
\hline & & \multirow{3}{*}{$\begin{array}{l}\text { Lat: } \sim 48^{\circ} 03^{\prime} 42.42^{\prime S} \mathrm{~S} \\
\text { Long: } \sim 166^{\circ} 30^{\prime} 59.99 " \mathrm{E} \\
\text { (L. Hunt) }\end{array}$} & nd6: & GU593850 \\
\hline & & & rbc-Sp: & GU593900 \\
\hline & & & ITS: & GU593800 \\
\hline \multirow[t]{5}{*}{ L. adamsiae } & \multirow[t]{5}{*}{ A616 } & \multirow[t]{2}{*}{ Tahi, The Snares, NZ } & atp8-Sp: & GU593751 \\
\hline & & & trnW-Sp: & GU593951 \\
\hline & & \multirow{3}{*}{$\begin{array}{l}\text { Lat: } \sim 48^{\circ} 03^{\prime} 42.42^{\prime S} \mathrm{~S} \\
\text { Long: } \sim 166^{\circ} 30^{\prime} 59.99 " \mathrm{E} \\
\text { (L. Hunt) }\end{array}$} & nd6: & GU593851 \\
\hline & & & rbc-Sp: & GU593901 \\
\hline & & & ITS: & GU593801 \\
\hline \multirow[t]{5}{*}{ L. adamsiae } & \multirow[t]{5}{*}{ A626 } & \multirow[t]{2}{*}{ South Promontory, The Snares, NZ } & atp8-Sp: & GU593752 \\
\hline & & & trnW-Sp: & GU593952 \\
\hline & & Lat: $\sim 48^{\circ} 0^{\prime} 54.38^{\prime \prime} \mathrm{S}$ & nd6: & GU593852 \\
\hline & & \multirow{2}{*}{$\begin{array}{l}\text { Long: } 166^{\circ} 34^{\prime} 40.55^{\prime \prime} \mathrm{E} \\
\text { (L. Hunt) }\end{array}$} & rbc-Sp: & GU593902 \\
\hline & & & ITS: & GU593802 \\
\hline \multirow[t]{2}{*}{ L. brevifolia } & \multirow[t]{2}{*}{ A548 } & \multirow{2}{*}{ Smoothwater Bay, Campbell Is., NZ } & atp8-Sp: & GU593753 \\
\hline & & & trnW-Sp: & GU593953 \\
\hline
\end{tabular}




\begin{tabular}{|c|c|c|c|c|}
\hline & & $\begin{array}{l}\text { Lat: } \sim 52^{\circ} 32^{\prime} 38.87^{\prime \prime S} \\
\text { Long: } \sim 169^{\circ} 15^{\prime} 9.09 " \mathrm{E} \\
\text { (D. Neale) }\end{array}$ & $\begin{array}{l}\text { nd6: } \\
\text { rbc-Sp: } \\
\text { ITS: }\end{array}$ & $\begin{array}{l}\text { GU593853 } \\
\text { GU593903 } \\
\text { GU593803 }\end{array}$ \\
\hline \multirow[t]{5}{*}{ L. brevifolia } & A973 & Antipodes, NZ & atp8-Sp: & GU593754 \\
\hline & & & trnW-Sp: & GU593954 \\
\hline & & Lat: $\sim 49^{\circ} 41^{\prime} 12.94 " \mathrm{~S}$ & nd6: & GU593854 \\
\hline & & Long: 178 46'13.05"E & rbc-Sp: & GU593904 \\
\hline & & (C. Fraser) & ITS: & GU593804 \\
\hline \multirow[t]{5}{*}{ L. brevifolia } & B296 & Perseverance Harbour, Campbell Is., & atp8-Sp: & GU593755 \\
\hline & & NZ & $\operatorname{trnW}-\mathrm{Sp}:$ & GU593955 \\
\hline & & Lat: $~ 52^{\circ} 33^{\prime} 40.07^{\prime \prime S}$ & nd6: & GU593855 \\
\hline & & Long: 169¹3'24.55"E & rbc-Sp: & GU593905 \\
\hline & & (C. Fraser) & ITS: & GU593805 \\
\hline \multirow[t]{5}{*}{ L. corrugata } & A985 & Bicheno, Tasmania, Tas & atp8-Sp: & GU593744 \\
\hline & & & trnW-Sp: & GU593944 \\
\hline & & Lat: $41^{\circ} 52^{\prime} 21.99^{\prime \prime S}$ & nd6: & GU593844 \\
\hline & & Long: $148^{\circ} 18^{\prime} 38.34^{\prime \prime} \mathrm{E}$ & rbc-Sp: & GU593894 \\
\hline & & (C. Boedeker) & ITS: & GU593794 \\
\hline \multirow[t]{5}{*}{ L. corrugata } & C057 & Skeleton Pt., Tasmania, Tas & atp8-Sp: & GU593745 \\
\hline & & & trnW-Sp: & GU593945 \\
\hline & & Lat: $41^{\circ} 14 ' 54.93 " \mathrm{~S}$ & nd6: & GU593845 \\
\hline & & Long: $148^{\circ} 19^{\prime} 46.11^{\prime \prime} \mathrm{E}$ & rbc-Sp: & GU593895 \\
\hline & & & ITS: & GU593795 \\
\hline L. nigrescens & A581 & La Pampilla, Coquimbo, Chile & atp8-Sp: & GU593725 \\
\hline \multirow[t]{4}{*}{ IA lineage } & & & trnW-Sp: & GU593925 \\
\hline & & Lat: $29^{\circ} 55^{\prime} 58.00^{\prime \prime S}$ & nd6: & GU593825 \\
\hline & & Long: $71^{\circ} 20^{\prime} 15.09^{\prime \prime} \mathrm{W}$ & rbc-Sp: & GU593875 \\
\hline & & (E. Macaya-Horta) & ITS: & GU593775 \\
\hline L. nigrescens & A584 & La Pampilla, Coquimbo, Chile & atp8-Sp: & GU593726 \\
\hline \multirow[t]{4}{*}{ IA lineage } & & & trnW-Sp: & GU593926 \\
\hline & & Lat: $29^{\circ} 55^{\prime} 58.00^{\prime \prime S}$ & nd6: & GU593826 \\
\hline & & Long: $71^{\circ} 20^{\prime} 15.09^{\prime \prime} \mathrm{W}$ & rbc-Sp: & GU593876 \\
\hline & & (E. Macaya-Horta) & ITS: & GU593776 \\
\hline L. nigrescens & A587 & La Pampilla, Coquimbo, Chile & atp8-Sp: & GU593727 \\
\hline \multirow[t]{4}{*}{ IA lineage } & & & trnW-Sp: & GU593927 \\
\hline & & Lat: $29^{\circ} 55^{\prime} 58.00^{\prime \prime} \mathrm{S}$ & nd6: & GU593827 \\
\hline & & Long: $71^{\circ} 20^{\prime} 15.09^{\prime \prime} \mathrm{W}$ & rbc-Sp: & GU593877 \\
\hline & & (E. Macaya-Horta) & ITS: & GU593777 \\
\hline L. nigrescens & B717 & Bahia Mansa, Osorno, Chile & atp8-Sp: & GU593728 \\
\hline \multirow[t]{3}{*}{ IA lineage } & & & $\operatorname{trnW}-\mathrm{Sp}:$ & GU593928 \\
\hline & & Lat: $40^{\circ} 33^{\prime} 53.33^{\prime \prime} \mathrm{S}$ & nd6: & GU593828 \\
\hline & & Long: $73^{\circ} 44^{\prime} 2.33^{\prime \prime} \mathrm{W}$ & rbc-Sp: & GU593878 \\
\hline
\end{tabular}




\begin{tabular}{|c|c|c|c|c|}
\hline & & (E. Macaya-Horta) & ITS: & GU593778 \\
\hline L. nigrescens & B718 & Bahia Mansa, Osorno, Chile & atp8-Sp: & GU593729 \\
\hline \multirow[t]{4}{*}{ IA lineage } & & & $\operatorname{trnW}-\mathrm{Sp}:$ & GU593929 \\
\hline & & Lat: $40^{\circ} 33^{\prime} 53.33^{\prime \prime S}$ & nd6: & GU593829 \\
\hline & & Long: $73^{\circ} 44^{\prime} 2.33^{\prime \prime} \mathrm{W}$ & rbc-Sp: & GU593879 \\
\hline & & (E. Macaya-Horta) & ITS: & GU593779 \\
\hline L. nigrescens & B719 & Bahia Mansa, Osorno, Chile & atp8-Sp: & GU593730 \\
\hline \multirow[t]{4}{*}{ IA lineage } & & & trnW-Sp: & GU593930 \\
\hline & & Lat: $40^{\circ} 33^{\prime} 53.33^{\prime \prime S}$ & nd6: & GU593830 \\
\hline & & Long: $73^{\circ} 44^{\prime} 2.33^{\prime \prime W}$ & rbc-Sp: & GU593880 \\
\hline & & (E. Macaya-Horta) & ITS: & GU593780 \\
\hline \multirow{5}{*}{$\begin{array}{l}\text { L. nigrescens } \\
\text { northern } \\
\text { lineage }\end{array}$} & B858 & San Marcos, Tarapaca, Chile & atp8-Sp: & GU593731 \\
\hline & & & trnW-Sp: & GU593931 \\
\hline & & Lat: $21^{\circ} 6^{\prime} 54.26^{\prime \prime S}$ & nd6: & GU593831 \\
\hline & & Long: $70^{\circ} 7 ' 34.14 " \mathrm{~W}$ & rbc-Sp: & GU593881 \\
\hline & & (E. Macaya-Horta) & ITS: & GU593781 \\
\hline \multirow{5}{*}{$\begin{array}{l}\text { L. nigrescens } \\
\text { northern } \\
\text { lineage }\end{array}$} & B859 & San Marcos, Tarapaca, Chile & atp8-Sp: & GU593732 \\
\hline & & & trnW-Sp: & GU593932 \\
\hline & & Lat: $21^{\circ} 6^{\prime} 54.26^{\prime \prime S}$ & nd6: & GU593832 \\
\hline & & Long: $70^{\circ} 7 ' 34.14 " \mathrm{~W}$ & rbc-Sp: & GU593882 \\
\hline & & (E. Macaya-Horta) & ITS: & GU593782 \\
\hline \multirow[t]{5}{*}{ L. tholiformis } & A517 & Wharf reef, Owenga, Chatham Is, NZ & atp8-Sp: & GU593746 \\
\hline & & & trnW-Sp: & GU593946 \\
\hline & & Lat: $44^{\circ} 1 ' 25.21^{\prime \prime S}$ & nd6: & GU593846 \\
\hline & & Long: $176^{\circ} 22^{\prime} 7.87^{\prime \prime} \mathrm{W}$ & rbc-Sp: & GU593896 \\
\hline & & (W. Nelson) & ITS: & GU593796 \\
\hline \multirow[t]{5}{*}{ L. tholiformis } & A518 & Wharf reef, Owenga, Chatham Is, NZ & atp8-Sp: & GU593747 \\
\hline & & & trnW-Sp: & GU593947 \\
\hline & & Lat: $44^{\circ} 1^{\prime} 25.21^{\prime \prime S}$ & nd6: & GU593847 \\
\hline & & Long: $176^{\circ} 22^{\prime} 7.87^{\prime \prime} \mathrm{W}$ & rbc-Sp: & GU593897 \\
\hline & & (W. Nelson) & ITS: & GU593797 \\
\hline \multirow[t]{5}{*}{ L. tholiformis } & A532 & Wharekauri, Chatham Is, NZ & atp8-Sp: & GU593748 \\
\hline & & & trnW-Sp: & GU593948 \\
\hline & & Lat: $\sim 43^{\circ} 42^{\prime} 15.18^{\prime \prime S}$ & nd6: & GU593848 \\
\hline & & Long: 176³4'54.12"W & rbc-Sp: & GU593898 \\
\hline & & (W. Nelson) & ITS: & GU593798 \\
\hline \multirow[t]{5}{*}{ L. trabeculata } & B715 & Punihuil, Chiloe Is, Chile & atp8-Sp: & GU593733 \\
\hline & & & trnW-Sp: & GU593933 \\
\hline & & Lat: $41^{\circ} 55 ' 25.96 " \mathrm{~S}$ & nd6: & GU593833 \\
\hline & & Long: $74^{\circ} 0^{\prime} 14.46^{\prime \prime} \mathrm{W}$ & rbc-Sp: & GU593883 \\
\hline & & (E. Macaya-Horta) & ITS: & GU593783 \\
\hline
\end{tabular}




\begin{tabular}{|c|c|c|c|c|}
\hline \multirow[t]{5}{*}{ L. trabeculata } & B716 & Punihuil, Chiloe Is, Chile & atp8-Sp: & GU593734 \\
\hline & & & $\operatorname{trnW}-\mathrm{Sp}:$ & GU593934 \\
\hline & & Lat: $41^{\circ} 55^{\prime} 25.96 " \mathrm{~S}$ & nd6: & GU593834 \\
\hline & & Long: $74^{\circ} 0^{\prime} 14.46^{\prime \prime} \mathrm{W}$ & rbc-Sp: & GU593884 \\
\hline & & (E. Macaya-Horta) & ITS: & GU593784 \\
\hline \multirow[t]{5}{*}{ L. trabeculata } & B834 & Rio Seco, Tarapaca, Chile & atp8-Sp: & GU593735 \\
\hline & & & trnW-Sp: & GU593935 \\
\hline & & Lat: $21^{\circ} 0^{\prime} 3.99^{\prime \prime S}$ & nd6: & GU593835 \\
\hline & & Long: $70^{\circ} 9^{\prime} 55.70^{\prime \prime} \mathrm{W}$ & rbc-Sp: & GU593885 \\
\hline & & (E. Macaya-Horta) & ITS: & GU593785 \\
\hline \multirow[t]{6}{*}{ (L. ovata) } & A634 & Rookery Bay, East Falkland, & atp8-Sp: & GU593736 \\
\hline & & Falkland Islands & $\operatorname{trnW}-\mathrm{Sp}:$ & GU593936 \\
\hline & & Lat $\sim 51^{\circ} 42^{\prime} 2000^{\prime \prime S}$ & nd6: & $\begin{array}{l}\text { GU593836 } \\
=A Y 857931\end{array}$ \\
\hline & & & & \\
\hline & & 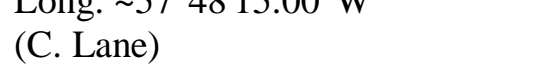 & IOC-Sp. & $=\mathrm{AY} 851543$ \\
\hline & & & ITS: & $\begin{array}{l}\text { GU593786 } \\
=A Y 857900\end{array}$ \\
\hline \multirow{5}{*}{$\begin{array}{l}\text { L. sp } \\
\text { determined as } \\
\text { L. flavicans }\end{array}$} & C156 & Surf Bay, East Falkland, Falkland & atp8-Sp: & GU593737 \\
\hline & & Islands (intertidal) & trnW-Sp: & GU593937 \\
\hline & & Lat: $51^{\circ} 41^{\prime} 31.04^{\prime \prime S}$ & nd6: & GU593837 \\
\hline & & Long: $57^{\circ} 46^{\prime} 7.94^{\prime \prime W}$ & rbc-Sp: & GU593887 \\
\hline & & (C. Fraser) & ITS: & GU593787 \\
\hline \multirow{5}{*}{$\begin{array}{l}\text { L. sp } \\
\text { determined as } \\
\text { L. flavicans }\end{array}$} & C160 & Surf Bay, East Falkland, Falkland & atp8-Sp: & GU593738 \\
\hline & & Islands (intertidal) & trnW-Sp: & GU593938 \\
\hline & & Lat: $51^{\circ} 41^{\prime} 31.04^{\prime \prime S}$ & nd6: & GU593838 \\
\hline & & Long: $57^{\circ} 46^{\prime} 7.94^{\prime \prime} \mathrm{W}$ & rbc-Sp: & GU593888 \\
\hline & & (C. Fraser) & ITS: & GU593788 \\
\hline \multirow[t]{5}{*}{ L. flavicans } & B985 & Punta Arenas, Patagonia, Chile & atp8-Sp: & GU593739 \\
\hline & & & trnW-Sp: & GU593939 \\
\hline & & Lat: $\sim 53^{\circ} 11^{\prime} 22.90^{\prime \prime S}$ & nd6: & GU593839 \\
\hline & & Long: 7052'21.84"W & rbc-Sp: & GU593889 \\
\hline & & (C. Cardenas) & ITS: & GU593789 \\
\hline \multirow[t]{5}{*}{ L. flavicans } & B986 & Punta Arenas, Patagonia, Chile & atp8-Sp: & GU593740 \\
\hline & & & trnW-Sp: & GU593940 \\
\hline & & Lat: $53^{\circ} 11^{\prime} 22.90^{\prime \prime S}$ & nd6: & GU593840 \\
\hline & & Long: 7052'21.84"W & rbc-Sp: & GU593890 \\
\hline & & (C. Cardenas) & ITS: & GU593790 \\
\hline \multirow[t]{4}{*}{ L. flavicans } & B987 & Punta Arenas, Patagonia, Chile & atp8-Sp: & GU593741 \\
\hline & & & trnW-Sp: & GU593941 \\
\hline & & Lat: $~ 53^{\circ} 11^{\prime} 22.90^{\prime \prime S}$ & nd6: & GU593841 \\
\hline & & Long: 7052'21.84"W & rbc-Sp: & GU593891 \\
\hline
\end{tabular}




\begin{tabular}{|c|c|c|c|c|}
\hline & & (C. Cardenas) & ITS: & GU593791 \\
\hline \multirow[t]{5}{*}{ L. flavicans } & B988 & Punta Arenas, Patagonia, Chile & atp8-Sp: & GU593742 \\
\hline & & & $\operatorname{trnW}-\mathrm{Sp}:$ & GU593942 \\
\hline & & Lat: $\sim 53^{\circ} 11^{\prime} 22.90^{\prime \prime S}$ & nd6: & GU593842 \\
\hline & & Long: 7052'21.84"W & rbc-Sp: & GU593892 \\
\hline & & (C. Cardenas) & ITS: & GU593792 \\
\hline \multirow[t]{5}{*}{ L. flavicans } & B989 & Punta Arenas, Patagonia, Chile & atp8-Sp: & GU593743 \\
\hline & & & trnW-Sp: & GU593943 \\
\hline & & Lat: $\sim 53^{\circ} 11^{\prime} 22.90^{\prime \prime S}$ & nd6: & GU593843 \\
\hline & & Long: 7052'21.84"W & rbc-Sp: & GU593893 \\
\hline & & (C. Cardenas) & ITS: & GU593793 \\
\hline \multirow{5}{*}{$\begin{array}{l}\text { L. variegata } \\
\text { lineage } \mathrm{N}\end{array}$} & A556 & North Cape, Northland, NZ & atp8-Sp: & GU593756 \\
\hline & & & trnW-Sp: & GU593956 \\
\hline & & Lat: $~ 34^{\circ} 24^{\prime} 8.36 " \mathrm{~S}$ & nd6: & GU593856 \\
\hline & & Long: 173²'5.64"E & rbc-Sp: & GU593906 \\
\hline & & (W. Nelson) & ITS: & GU593806 \\
\hline \multirow{5}{*}{$\begin{array}{l}\text { L. variegata } \\
\text { lineage } \mathrm{N}\end{array}$} & A557 & North Cape, Northland, NZ & atp8-Sp: & GU593758 \\
\hline & & & trnW-Sp: & GU593958 \\
\hline & & Lat: $\sim 34^{\circ} 24^{\prime} 8.36^{\prime \prime} \mathrm{S}$ & nd6: & GU593858 \\
\hline & & Long: 173²'5.64"E & rbc-Sp: & GU593908 \\
\hline & & (W. Nelson) & ITS: & GU593808 \\
\hline \multirow{5}{*}{$\begin{array}{l}\text { L. variegata } \\
\text { lineage } \mathrm{N}\end{array}$} & B129 & Maitai Bay, Northland, NZ & atp8-Sp: & GU593759 \\
\hline & & & $\operatorname{trnW}-\mathrm{Sp}:$ & GU593959 \\
\hline & & Lat: $34^{\circ} 49^{\prime} 36.54^{\prime \prime S}$ & nd6: & GU593859 \\
\hline & & Long: $173^{\circ} 24^{\prime} 47.88^{\prime \prime E}$ & rbc-Sp: & GU593909 \\
\hline & & & ITS: & GU593809 \\
\hline \multirow{5}{*}{$\begin{array}{l}\text { L. variegata } \\
\text { lineage } \mathrm{N}\end{array}$} & B210 & Outer South Head, Omapere, NZ & atp8-Sp: & GU593757 \\
\hline & & & $\operatorname{trnW}-\mathrm{Sp}:$ & GU593957 \\
\hline & & Lat: $35^{\circ} 32^{\prime} 16.28^{\prime \prime S}$ & nd6: & GU593857 \\
\hline & & Long: $173^{\circ} 21^{\prime} 55.67^{\prime \prime E}$ & rbc-Sp: & GU593907 \\
\hline & & & ITS: & GU593807 \\
\hline \multirow{5}{*}{$\begin{array}{l}\text { L. variegata } \\
\text { lineage } \mathrm{N}\end{array}$} & B312 & The Sailors Grave, Coromandel, NZ & atp8-Sp: & GU593760 \\
\hline & & & trnW-Sp: & GU593960 \\
\hline & & Lat: $36^{\circ} 57^{\prime} 39.33^{\prime \prime S}$ & nd6: & GU593860 \\
\hline & & Long: $175^{\circ} 50^{\prime} 41.36^{\prime \prime} \mathrm{E}$ & rbc-Sp: & GU593910 \\
\hline & & (J. Buchanan) & ITS: & GU593810 \\
\hline \multirow{5}{*}{$\begin{array}{l}\text { L. variegata } \\
\text { lineage } \mathrm{W}\end{array}$} & A001 & Princess Bay, Wellington, NZ & atp8-Sp: & GU593761 \\
\hline & & & $\operatorname{trnW}-\mathrm{Sp}:$ & GU593961 \\
\hline & & Lat: $41^{\circ} 20^{\prime} 42.36 " \mathrm{~S}$ & nd6: & GU593861 \\
\hline & & Long: $174^{\circ} 47^{\prime} 15.89^{\prime \prime E}$ & rbc-Sp: & GU593911 \\
\hline & & & ITS: & GU593811 \\
\hline L. variegata & A002 & Princess Bay, Wellington, NZ & atp8-Sp: & GU593762 \\
\hline
\end{tabular}


lineage $\mathrm{W}$

trnW-Sp: GU593962

Lat: $41^{\circ} 20^{\prime} 42.36 " \mathrm{~S}$

nd6:

GU593862

Long: $174^{\circ} 47^{\prime} 15.89^{\prime \prime} \mathrm{E}$

rbc-Sp: GU593912

ITS:

GU593812

L. variegata $\mathrm{A} 003$
lineage $\mathrm{W}$

Princess Bay, Wellington, NZ

atp8-Sp: GU593763

Lat: $41^{\circ} 20^{\prime} 42.36 " \mathrm{~S}$

trnW-Sp: GU593963

Long: $174^{\circ} 47^{\prime} 15.89^{\prime \prime} \mathrm{E}$

nd6:

GU593863

rbc-Sp: GU593913

ITS:

GU593813

L. variegata $\mathrm{A} 025$
lineage $\mathrm{W}$

Riversdale Beach, Wairarapa, NZ

atp8-Sp: GU593766

Lat: $41^{\circ} 6 ' 29.73 " \mathrm{~S}$

trnW-Sp: GU593966

Long: $176^{\circ} 4^{\prime} 10.55^{\prime \prime} \mathrm{E}$

nd6:

GU593866

rbc-Sp: GU593916

ITS: $\quad$ GU593816

\begin{tabular}{lll}
\hline L. variegata & A500 & Whites Bay, Marlborough Sounds, \\
lineage W & & NZ \\
& Lat: $41^{\circ} 23^{\prime} 17.96^{\prime \prime S}$ \\
& Long: $174^{\circ} 3$ '23.28"E
\end{tabular}

atp8-Sp: GU593764

trnW-Sp: GU593964

nd6: $\quad$ GU593864

rbc-Sp: GU593914

ITS: $\quad$ GU593814

L. variegata A613 Cape Palliser, Wairarapa, NZ

lineage $\mathrm{W}$

Lat: $41^{\circ} 36^{\prime} 48.47^{\prime \prime S}$

Long: $175^{\circ} 17^{\prime} 32.66^{\prime \prime} \mathrm{E}$

atp8-Sp: GU593765

trnW-Sp: GU593965

nd6: $\quad$ GU593865

rbc-Sp: GU593915

ITS: GU593815

\begin{tabular}{lll}
\hline L. variegata & A138 & South Bay, Kaikoura, NZ
\end{tabular}

lineage $\mathrm{K}$

Lat: $42^{\circ} 25^{\prime} 33.45^{\prime \prime} \mathrm{S}$

Long: $173^{\circ} 41^{\prime} 6.25 " \mathrm{E}$

atp8-Sp: GU593767

trnW-Sp: GU593967

nd6: $\quad$ GU593867

rbc-Sp: GU593917

ITS: $\quad$ GU593817

L. variegata $\quad$ A606 New Wharf, Kaikoura, NZ

lineage $\mathrm{K}$

Lat: $42^{\circ} 24^{\prime} 47.17 " \mathrm{~S}$

Long: $173^{\circ} 42^{\prime} 8.22 " \mathrm{E}$

atp8-Sp: GU593768

trnW-Sp: GU593968

nd6: $\quad$ GU593868

rbc-Sp: GU593918

(R. Dunmore)

ITS: $\quad$ GU593818

\begin{tabular}{ll}
\hline L. variegata & A779 \\
lineage $\mathrm{K}$ &
\end{tabular}

atp8-Sp: GU593769

trnW-Sp: GU593969

nd6: $\quad$ GU593869

Lat: $41^{\circ} 43^{\prime} 46.18^{\prime \prime} \mathrm{S}$

rbc-Sp: GU593919

Long: $174^{\circ} 16^{\prime} 19.08^{\prime \prime} \mathrm{E}$

ITS: $\quad$ GU593819

L. variegata A434 Curio Bay, Catlins, NZ

lineage $\mathrm{S}$

Lat: $46^{\circ} 39^{\prime} 38.85^{\prime \prime} \mathrm{S}$

atp8-Sp: GU593770

trnW-Sp: GU593970

nd6: $\quad$ GU593870 
Long: $169^{\circ} 6^{\prime} 29.45 " \mathrm{E} \quad$ rbc-Sp: GU593920

ITS: $\quad$ GU593820

\begin{tabular}{|c|c|c|c|c|}
\hline L. variegata & C154 & Causet Cove, Doubtful Sound, NZ & atp8-Sp: & GU593771 \\
\hline lineage $S$ & & & trnW-Sp: & GU593971 \\
\hline & & Lat: $45^{\circ} 17^{\prime} 47.63^{\prime \prime S}$ & nd6: & GU593871 \\
\hline & & Long: $166^{\circ} 54^{\prime} 33.01^{\prime E}$ & rbc-Sp: & GU593921 \\
\hline & & (W. Nelson) & ITS: & GU593821 \\
\hline L. variegata & $\mathrm{C} 155$ & Shelter Islands, Doubtful Sound, NZ & atp8-Sp: & GU593772 \\
\hline lineage $S$ & & & trnW-Sp: & GU593972 \\
\hline & & Lat: $45^{\circ} 16^{\prime} 13.54^{\prime \prime S}$ & nd6: & GU593872 \\
\hline & & Long: $166^{\circ} 53^{\prime 2} 29.26 " \mathrm{E}$ & rbc-Sp: & GU593922 \\
\hline & & (W. Nelson) & ITS: & GU593822 \\
\hline $\begin{array}{l}\text { Laminaria } \\
\text { ephemera }\end{array}$ & $\mathrm{C} 202$ & $\begin{array}{l}\text { Salmon Banks (FHL), Washington, } \\
\text { USA }\end{array}$ & atp8-Sp: & \\
\hline & & Lat: $-48^{\circ} 26^{\prime} 10^{\prime \prime} \mathrm{N}$ & trnW-Sp: & \\
\hline & & Long: $123^{\circ} 02^{\prime} 20^{\prime \prime} \mathrm{W}$ & ITS: & \\
\hline L. ephemera & $\begin{array}{l}\text { (used to } \\
\text { complete }\end{array}$ & $\begin{array}{l}\text { Botanical Beach, Port Renfrew, BC, } \\
\text { Canada }\end{array}$ & & AY857924 \\
\hline & & (C. Lane) & rbc-Sp: & AY851557 \\
\hline & sequences & & & \\
\hline & missing & & & \\
\hline & in C202) & & & \\
\hline
\end{tabular}


Table S 2.2 Primer characteristics and their coded PCR-profiles (see Fig. S1). Primers in bold were developed for this study. The original primer was put in brackets if only slight modifications were made. ${ }^{\mathrm{a}}$ after Voisin et al. 2005; ${ }^{\mathrm{b}}$ after Lane at al. 2006; ${ }^{\mathrm{c}}$ after Peters \& Ramirez 2001; ${ }^{\mathrm{d}}$ after Tai et al. 2001.

\begin{tabular}{|c|c|c|c|}
\hline \multicolumn{2}{|c|}{ ATP8-spacer region $(\sim 172 b p)$} & \multirow{2}{*}{$\begin{array}{l}\text { Length } \\
27 \mathrm{bp}\end{array}$} & \multirow{2}{*}{$\begin{array}{l}\% G C \\
33\end{array}$} \\
\hline $\operatorname{atp} 8^{\mathrm{a}}$ & tgtacgtttcatattaccttctttagc & & \\
\hline $\operatorname{atp} 8 \mathrm{R}^{\mathrm{a}}$ & tagcaaaccaaggctttcaac & $21 b p$ & 43 \\
\hline PCR-profile & Td VI 55/(5)33x & & \\
\hline \multicolumn{4}{|c|}{ trnW-spacer region ( 238bp) } \\
\hline $\operatorname{trn} W^{\mathrm{a}}$ & ggggttcaaatccetctctt & $20 b p$ & 50 \\
\hline $\operatorname{trnW}-\mathrm{R}^{\mathrm{a}}$ & cctacattgttagcttcatgagaa & $24 b p$ & 37 \\
\hline PCR-profile & Td VI 55/(5)33x & & \\
\hline \multicolumn{4}{|c|}{ nd6 gene (1159bp) } \\
\hline $\mathrm{KM} 1^{\mathrm{b}}$ & tcttattgaaagtttagggcc & $21 \mathrm{bp}$ & 38 \\
\hline n6iR $\left(K_{M} 2 N^{b}\right)$ & tctataaaccacattrtattta & 22bp & 18 \\
\hline n6i (KM5 $\left.{ }^{b}\right)$ & tcttttagtttagtrtctta & 20bp & 20 \\
\hline n6R & tagattcacgacctccytgac & $21 b p$ & 48 \\
\hline PCR-profile & nd6 $50^{\circ} / 35 x$ & & \\
\hline \multicolumn{4}{|c|}{ rbc-spacer (363bp) } \\
\hline $\operatorname{rbcLSS}\left(\mathrm{KR5}^{\mathrm{b}}\right)$ & acttcaacagatacacctga & 20bp & 40 \\
\hline $\mathrm{rbcS} 97 \mathrm{R}^{\mathrm{c}}$ & catctgtccattctacactaac & $22 b p$ & 41 \\
\hline PCR-profile & $\mathrm{rbc} 45^{\circ} / 35 \mathrm{x}$ & & \\
\hline \multicolumn{4}{|l|}{$\operatorname{ITS}(\sim 850 \mathrm{bp})$} \\
\hline ITSP $^{d}$ & ggaaggagaagtcgtaacaagg & $22 \mathrm{bp}$ & 50 \\
\hline $\mathrm{KP}^{\mathrm{b}}$ & acaacgatgaagaacgcag & $19 b p$ & 47 \\
\hline ITSRi (KIR1 $\left.{ }^{b}\right)$ & ttcaaagttttgatgattcac & $21 \mathrm{bp}$ & 29 \\
\hline $\mathrm{KG} 4^{\mathrm{b}}$ & cttttcctccgettagttatatg & $23 b p$ & 39 \\
\hline PCR-profile & ITS $50^{\circ} / 31 x$ & & \\
\hline
\end{tabular}


Table S 2.3 Partition-homogeneity test or Incongruence Length Test (PAUP*) with heuristic search (nreps=100; TBR). A test to verify whether different datasets can be combined into a supermatrix. Cunningham (1997) suggested that p-values $>0.01$ indicate that combining the data will generally improve the accuracy of the phylogeny. If p-values are $<0.001$ the accuracy of the combined data would suffer relative to the individual partitions. The combination of the marker datasets into a supermatrix (matrix-I) is favoured.

Dataset: matrix-I

Test including outgroup (B701Ec, A106Er)

$\mathrm{p}=\mathbf{0 . 0 6}$

Pairwise test of Homogeneity

$\begin{array}{llllll}\text { p-values } & \text { atp8 } & \text { trnW } & \text { nd6 } & \text { rbc } & \text { ITS } \\ \text { atp8 } & - & 0.59 & 0.89 & 0.68 & 0.28 \\ \text { trnW } & & - & 0.15 & 0.75 & 0.01 \\ \text { nd6 } & & & - & 0.69 & 0.03 \\ \text { rbc } & & & & - & 0.98 \\ \text { ITS } & & & & & -\end{array}$

Test without outgroup

$\mathrm{p}=\mathbf{0 . 0 3}$

Pairwise test of Homogeneity

$\begin{array}{llllll}\text { p-values } & \text { atp8 } & \text { trnW } & \text { nd6 } & \text { rbc } & \text { ITS } \\ \text { atp8 } & - & 0.51 & 0.87 & 0.78 & 0.11 \\ \text { trnW } & & - & 0.14 & 0.89 & 0.01 \\ \text { nd6 } & & & - & 0.71 & 0.01 \\ \text { rbc } & & & & - & 1.00 \\ \text { ITS } & & & & & -\end{array}$


Table S 2.4 Partition strategy test (Tracer v1.5). BF > 20 is strong support for favoured model. Nst=6 Rates=invgamma ngammacat=8 [was applied separately for all partitions]. The partition of the supermatrix by marker regions and in case of the nd6-gene additionally by codon position is favoured.

number of partitions

$\ln \mathrm{L}$

over 1000 bootstraps single partition 1

$-7912.708$

$-7932.395$ marker 5

$-7726.410$

$-7747.549 \quad-7670.276$ 7
BF

single partition

marker

marker + codon pos. single partition

marker

80.278

113.837 marker + codon pos.

marker + codon pos.

References: Newton \& Raftery (1994) with modifications proposed by Suchard et al. (2001, MBE 18: 1001-1013) 
Table S 2.5 HKY-distances (matrix-I) between and within lineages (PAUP*). F = Falkland Is, IA = intermediate area, $\mathrm{K}=\mathrm{Kaikoura}, \mathrm{N}=$ northern, $\mathrm{P}=\mathrm{Patagonia}$, $\mathrm{S}=$ southern, sc = species complex, $\mathrm{W}=$ Wellington. Table S5a. Ingroup comparison. Table S5b. Outgroup comparison

\begin{tabular}{|c|c|c|c|c|c|c|c|c|c|c|c|c|c|c|c|c|c|c|}
\hline & $\begin{array}{l}\text { L. nig } \\
\text { /sc }\end{array}$ & $\begin{array}{l}\text { L. nig } \\
\text { /IA }\end{array}$ & $\begin{array}{l}\text { L. nig } \\
/ \mathrm{N}\end{array}$ & L. tra & $\begin{array}{l}\text { L. tra } \\
\text { /S }\end{array}$ & $\begin{array}{l}\text { L. tra } \\
\text { /N }\end{array}$ & L. vad & $\begin{array}{l}\text { L. vad } \\
\text { /F }\end{array}$ & $\begin{array}{l}\text { L.vad } \\
\text { /P }\end{array}$ & L. cor & L. tho & L. $a d a$ & L. bre & $\begin{array}{l}\text { L. var } \\
\text { /sc }\end{array}$ & $\begin{array}{l}\text { L. var } \\
/ \mathrm{N}\end{array}$ & $\begin{array}{l}\text { L. var } \\
\text { /W }\end{array}$ & $\begin{array}{l}\text { L. var } \\
/ \mathrm{K}\end{array}$ & $\begin{array}{l}\text { L. var } \\
\text { /S }\end{array}$ \\
\hline $\begin{array}{l}\text { L. nigrescens } \\
/ \mathrm{sc}\end{array}$ & - & & & & & & & & & & & & & & & & & \\
\hline L. nig/IA & $\mathrm{n} / \mathrm{a}$ & - & & & & & & & & & & & & & & & & \\
\hline L. $n i g / \mathrm{N}$ & $\mathrm{n} / \mathrm{a}$ & 0.0232 & - & & & & & & & & & & & & & & & \\
\hline L. trabeculata & 0.0249 & 0.0232 & 0.0302 & - & & & & & & & & & & & & & & \\
\hline L. $\operatorname{tra} / \mathrm{S}$ & 0.0245 & 0.0227 & 0.0299 & $\mathrm{n} / \mathrm{a}$ & - & & & & & & & & & & & & & \\
\hline L. tra $/ \mathrm{N}$ & 0.0258 & 0.0241 & 0.0308 & $\mathrm{n} / \mathrm{a}$ & 0.0053 & - & & & & & & & & & & & & \\
\hline L. vadosa & 0.0366 & 0.0354 & 0.0401 & 0.0227 & 0.0225 & 0.0230 & - & & & & & & & & & & & \\
\hline L. vad/F & 0.0354 & 0.0341 & 0.0391 & 0.0209 & 0.0209 & 0.0209 & $\mathrm{n} / \mathrm{a}$ & - & & & & & & & & & & \\
\hline L. vad/P & 0.0373 & 0.0362 & 0.0407 & 0.0237 & 0.0234 & 0.0243 & $\mathrm{n} / \mathrm{a}$ & 0.0071 & - & & & & & & & & & \\
\hline L. corrugata & 0.0469 & 0.0466 & 0.0480 & 0.0376 & 0.0379 & 0.0370 & 0.0337 & 0.0325 & 0.0344 & - & & & & & & & & \\
\hline L. tholiformis & 0.0426 & 0.0415 & 0.0459 & 0.0329 & 0.0331 & 0.0326 & 0.0330 & 0.0319 & 0.0337 & 0.0349 & - & & & & & & & \\
\hline L. adamsiae & 0.0403 & 0.0388 & 0.0450 & 0.0301 & 0.0304 & 0.0295 & 0.0287 & 0.0278 & 0.0292 & 0.0208 & 0.0281 & - & & & & & & \\
\hline L. brevifolia & 0.0461 & 0.0443 & 0.0514 & 0.0389 & 0.0392 & 0.0383 & 0.0375 & 0.0363 & 0.0383 & 0.0357 & 0.0345 & 0.0294 & - & & & & & \\
\hline L. variegata $/ \mathrm{sc}$ & 0.0443 & 0.0434 & 0.0470 & 0.0346 & 0.0348 & 0.0341 & 0.0350 & 0.0341 & 0.0356 & 0.0333 & 0.0325 & 0.0278 & 0.0359 & - & & & & \\
\hline L. $\operatorname{var} / \mathrm{N}$ & 0.0447 & 0.0439 & 0.0470 & 0.0344 & 0.0341 & 0.0350 & 0.0350 & 0.0339 & 0.0356 & 0.0339 & 0.0322 & 0.0302 & 0.0360 & $\mathrm{n} / \mathrm{a}$ & - & & & \\
\hline L. var $/ \mathrm{W}$ & 0.0429 & 0.0417 & 0.0463 & 0.0350 & 0.0356 & 0.0338 & 0.0349 & 0.0341 & 0.0353 & 0.0319 & 0.0332 & 0.0258 & 0.0337 & $\mathrm{n} / \mathrm{a}$ & 0.0323 & - & & \\
\hline
\end{tabular}


Table $\mathbf{S} 2.5$ continued

\begin{tabular}{|c|c|c|c|c|c|c|c|c|c|c|c|c|c|c|c|c|c|c|}
\hline L. $\operatorname{var} / \mathrm{K}$ & 0.0512 & 0.0509 & 0.0520 & 0.0390 & 0.0395 & 0.0381 & 0.0395 & 0.0384 & 0.0401 & 0.0385 & 0.0367 & 0.0361 & 0.0425 & $\mathrm{n} / \mathrm{a}$ & 0.0399 & 0.0380 & - & \\
\hline L. var $/ \mathrm{S}$ & 0.0395 & 0.0383 & 0.0431 & 0.0295 & 0.0297 & 0.0291 & 0.0310 & 0.0301 & 0.0314 & 0.0297 & 0.0276 & 0.0195 & 0.0333 & $\mathrm{n} / \mathrm{a}$ & 0.0309 & 0.0284 & 0.0348 & - \\
\hline Overall mean & 0.0123 & 0.0044 & 0.0004 & 0.0035 & 0.0000 & $\mathrm{n} / \mathrm{a}$ & 0.0042 & 0.0013 & 0.0008 & 0.0026 & 0.0022 & 0.0005 & 0.0023 & 0.0265 & 0.0032 & 0.0012 & 0.0003 & 0.0032 \\
\hline $\begin{array}{l}\text { Max. within } \\
\text { group }\end{array}$ & 0.0246 & 0.0075 & 0.0004 & 0.0053 & 0.0000 & $\mathrm{n} / \mathrm{a}$ & 0.0079 & 0.0018 & 0.0013 & 0.0026 & 0.0031 & 0.0009 & 0.0026 & 0.0416 & 0.0040 & 0.0018 & 0.0004 & 0.0044 \\
\hline
\end{tabular}

\section{Table S2.5b. Outgroup comparison}

\begin{tabular}{|l|l|l|l|l|l|l|l|}
\hline & Lessonia & MpA005 & UpA004 & EbB699 & LeC203 & EcB701 & ErA106 \\
\hline Lessonia (all) & - & & & & & & \\
\hline Macrocystis pyrifera A005 & 0.1592 & - & & & & & \\
\hline Undaria pinnatifida A004 & 0.1572 & 0.1601 & - & & & & \\
\hline Eisenia bicyclis B699 & 0.1487 & 0.1545 & 0.1593 & - & & & \\
\hline Laminaria ephemera C203 & 0.1387 & 0.1604 & 0.1476 & 0.1469 & - & & \\
\hline Ecklonia cava B701 & 0.1568 & 0.1645 & 0.1676 & 0.0535 & 0.1507 & - & \\
\hline Ecklonia radiata A106 & 0.1566 & 0.1627 & 0.1635 & 0.0537 & 0.151 & 0.0281 & - \\
\hline
\end{tabular}


Table S 2.6 Molecular clock test (PAUP*). T1 = without clock; T2 =clock enforced. AA = Australasia, SA = South America. Molecular clock was rejected for all Lessonia but accepted for tests within geographic groups ( $\mathrm{p}=0.001)$. Bonferroni was not applied as the $\mathrm{p}$-values depent on the topology. For the root position see Table S 2.7.

$\begin{array}{llll} & \begin{array}{l}\text { Clock test } \\ \text { rootA }\end{array} & \begin{array}{l}\text { Clock test } \\ \text { rootB }\end{array} & \begin{array}{l}\text { Clock test } \\ \text { rootC }\end{array} \\ \text { T1 (-ln L1) } & 6474.632 & 6474.632 & 6474.632 \\ \text { T2 (-ln L2) } & 6529.349 & 6518.997 & 6515.383 \\ \text { ntax } & 48 & 48 & 48 \\ \text { (T1-T2)·2 } & 109.434 & 88.729 & 81.503 \\ \text { deg_freedom } & 48 & 48 & 48 \\ \text { p-value } & \begin{array}{l}4.365 \mathrm{E}-07 \\ \text { clock is } \\ \text { rejected }\end{array} & \begin{array}{l}1.578 \mathrm{E}-04 \\ \text { clock is } \\ \text { rejected }\end{array} & \begin{array}{l}\text { 9.755E-04 } \\ \text { clock is } \\ \text { rejected }\end{array}\end{array}$

$\begin{array}{llll} & \text { Clock test AA } & \begin{array}{l}\text { Clock test SA } \\ \text { rootA }\end{array} & \begin{array}{l}\text { Clock test SA } \\ \text { rootB or C }\end{array} \\ \text { T1 (-ln L1) } & 5637.302 & 4193.942 & 4193.942 \\ \text { T2 (-ln L2) } & 5657.455 & 4209.296 & 4214.176 \\ \text { ntax } & 30 & 19 & 19 \\ \text { (T1-T2)·2 } & 40.307 & 30.709 & 40.468 \\ \text { deg_freedom } & 28 & 17 & 17 \\ \text { p-value } & \begin{array}{l}0.062 \\ \text { clock is } \\ \text { accepted }\end{array} & \begin{array}{l}0.022 \\ \text { clock is } \\ \text { accepted }\end{array} & \begin{array}{l}0.001 \\ \text { clock is } \\ \text { accepted }\end{array}\end{array}$


Table S 2.7 Topology test (Paired Sites Tests in treefinder version of October 2008). No topology is rejected, but TopoA has the best support.
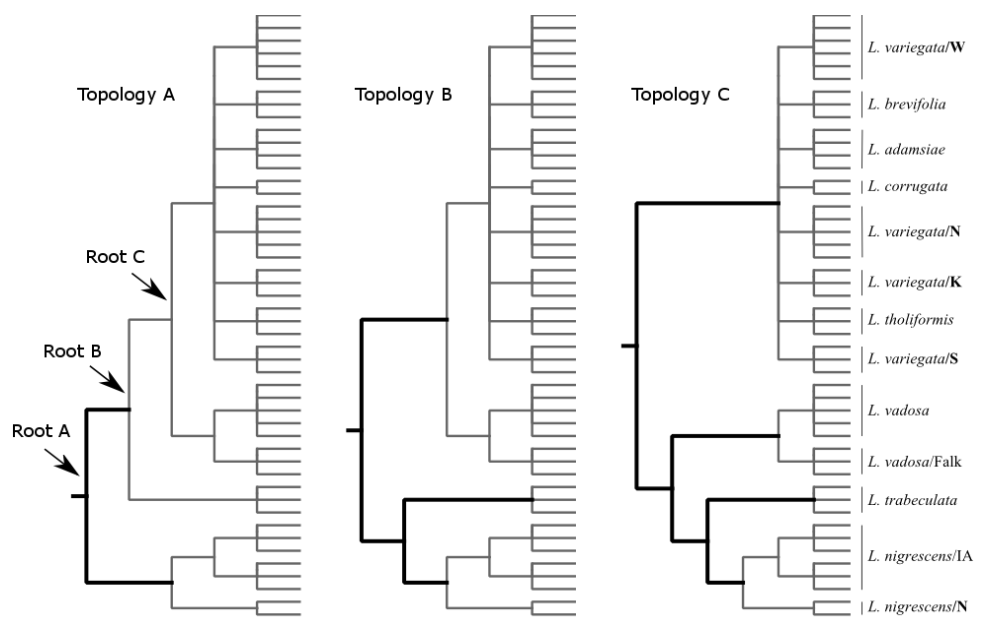

martix-I (Lorigin-gXF)

$\begin{array}{llll} & \text { TopoA } & \text { TopoB } & \text { TopoC } \\ \text { ELW: } & \mathbf{0 . 3 5} & 0.32 & 0.34 \\ \text { BP: } & \mathbf{0 . 4 2} & 0.24 & 0.33 \\ \text { KH: } & \mathbf{1 . 0 0} & 0.43 & 0.38 \\ \text { SH: } & \mathbf{1 . 0 0} & 0.58 & 0.57 \\ \text { WSH: } & \mathbf{1 . 0 0} & 0.58 & 0.57 \\ \text { AU: } & \mathbf{0 . 6 1} & 0.37 & 0.55 \\ \text { Likelihood: } & \mathbf{- 6 3 6 9 . 5 2} & -6369.65 & -6369.54 \\ \text { AIC: } & \mathbf{1 3 0 2 5 . 0 4} & 13025.30 & 13025.08 \\ \text { AICc: } & \mathbf{1 3 0 4 4 . 3 2} & 13044.58 & 13044.36 \\ \text { BIC: } & \mathbf{1 3 8 4 4 . 7 0} & 13844.96 & 13844.75 \\ \text { HQ: } & \mathbf{1 3 3 2 4 . 0 1} & 13324.27 & 13324.05 \\ \text { \#Sites: } & 2280 & 2280 & 2280 \\ \text { \#Param.: } & 143 & 143 & 143\end{array}$

matrix-II (mg-dataset)

$\begin{array}{llll} & \text { TopoA } & \text { TopoB } & \text { TopoC } \\ \text { ELW: } & 0.34 & 0.34 & 0.32 \\ \text { BP: } & \mathbf{0 . 4 9} & 0.40 & 0.11 \\ \text { KH: } & \mathbf{1 . 0 0} & 0.38 & 0.05 \\ \text { SH: } & \mathbf{1 . 0 0} & 0.47 & 0.25 \\ \text { WSH: } & \mathbf{1 . 0 0} & 0.47 & 0.11 \\ \text { AU: } & \mathbf{0 . 6 7} & 0.50 & 0.24 \\ \text { Likelihood: } & \mathbf{- 6 2 6 4 . 9 3} & -6264.97 & -6264.97 \\ \text { AIC: } & \mathbf{1 2 8 1 5 . 8 6} & 12815.93 & 12815.94 \\ \text { AICc: } & \mathbf{1 2 8 3 5 . 1 4} & 12835.22 & 12835.22 \\ \text { BIC: } & \mathbf{1 3 6 3 5 . 5 3} & 13635.60 & 13635.60 \\ \text { HQ: } & \mathbf{1 3 1 1 4 . 8 3} & 13114.91 & 13114.91 \\ \text { \#Sites: } & 2280 & 2280 & 2280 \\ \text { \#Param.: } & 143 & 143 & 143\end{array}$


Table S 2.8 Average difference in GC-content (matrix-I)

$\begin{array}{ll}\text { All } & \mathbf{0 . 0 0 3 7 5 3} \\ \text { within SA } & 0.003823 \\ \text { within AA } & 0.002395 \\ \text { between SA/AA } & 0.003777\end{array}$




\subsubsection{Appendix}

S1 Mutation rates

Estimation of mutation rates using HKY-distances (after Hoarau et al. 2007, and Tellier et al. 2009). HKY distances were calculated in PAUP*

A) psbA-gene divergence rate (as in Hoarau et al. 2007)

Table A 2.9.3.1 psbA-gene divergence rate (as in Hoarau et al. 2007); HKY corrected distances were used to account for saturation effect of the marker.

Haslea ostrearia Y15074

Skeletonema costatum Y15137

Laminaria digitata AY528849

Alaria crassifolia AY528847
[1]

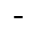

0.07545

0.18828

0.18829

Divergence time between Haslea and Skeletonema = 65-87 My (Hoarau et al. 2007)

[2]

0.16428

0.16428
[3]

0.01146

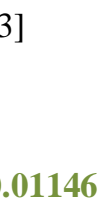

B) psbA clock (using divergence trate and time between Haslea and Skeletonema)

$$
\begin{aligned}
& 0.07545 / 87=0.000867241 \mathrm{My}^{-1}=0.087 \% \mathrm{My}^{-1} \\
& \text { to } 0.07545 / 65=0.001160769 \mathrm{My}^{-1}=0.116 \% \mathrm{My}^{-1}
\end{aligned}
$$

C) Divergence time between Laminaria and Alaria based on psbA clock (after

Tellier et al. 2009)

$$
\begin{aligned}
& 0.01146 / 0.001160769 \mathrm{My}^{-1}=9.9 \mathrm{My} \\
& 0.01146 / 0.000867241 \mathrm{My}^{-1}=13.2 \mathrm{My}
\end{aligned}
$$

(Tellier et al. 2009 had calculated a divergence time of 10 - 15 My)

D) Calculation of divergence rates given the divergence time between Laminaria and Alaria of 9.9 to 13.2 Mya

D1) rbc-Sp divergence rate 
Samples used:

Alaria esculenta AF109802 and A. marginata AF318959

Laminaria digitata AY851559 and L. sinclairii AY851558

Lessonia nigrescens B858N, L. variegata/N B210, and L. variegata/W A001

Table A 2.9.3.2 HKY corrected distance of rbc-Sp

$\begin{array}{llll} & \text { Ala } & \text { Lam } & \text { Les } \\ \text { Ala } & - & & \\ \text { Lam } & 0.079 & - & \\ \text { Les } & 0.076 & 0.049 & -\end{array}$

Average between group $=0.068$ (Average used in Tellier et al. $2009=0.08$ )

Table A 2.9.3.3 Corrected divergence rate for rbc-Sp in $\mathrm{My}^{-1}$

$\begin{array}{llll} & \min & \max & \text { mean } \\ \text { divergence rate } & 0.0051 & 0.0069 & 0.0060 \\ \text { mutation rate } & 0.0026 & 0.0034 & 0.0030\end{array}$

D2) atp8-Sp divergence rate

Samples used:

Alaria esculenta DQ841616 and DQ841615

Laminaria digitata DQ841608 and DQ841607

Lessonia nigrescens B858N, L. variegata/N B210, and L. variegata/W A001

Table A 2.9.3.4 HKY corrected distance of atp8-Sp

$\begin{array}{llll} & \text { Ala } & \text { Lam } & \text { Les } \\ \text { Ala } & - & & \\ \text { Lam } & 0.229 & - & \\ \text { Les } & 0.299 & 0.258 & -\end{array}$

Average between group $=0.262$

Table A 2.9.3.5 Corrected divergence rate for atp8-Sp in $\mathrm{My}^{-1}$

$\begin{array}{llll} & \min & \max & \text { mean } \\ \text { divergence rate } & 0.0197 & 0.0264 & 0.0230 \\ \text { mutation rate } & 0.0098 & 0.0132 & 0.0115\end{array}$


D3) trnW-Sp divergence rate

Samples used:

Alaria esculenta DQ841679 and DQ841680

Laminaria digitata DQ841669 and DQ841670

Lessonia nigrescens B858N, L. variegata/N B210, and L. variegata/W A001

Table A 2.9.3.6 HKY corrected distance of trnW-Sp

$\begin{array}{llll} & \text { Ala } & \text { Lam } & \text { Les } \\ \text { Ala } & - & & \\ \text { Lam } & 0.128 & - & \\ \text { Les } & 0.206 & 0.162 & -\end{array}$

Average between group $=0.165$

Table A 2.9.3.7 Corrected divergence rate for trnW-Sp in $\mathrm{My}^{-1}$

$\begin{array}{llll} & \min & \max & \text { mean } \\ \text { divergence rate } & 0.0124 & 0.0166 & 0.0145 \\ \text { mutation rate } & 0.0062 & 0.0083 & 0.0073\end{array}$

D4) nd6-gene divergence rate

Samples used:

Alaria esculenta AY878857, A. marginata AY878858, and A. nana AY878859

Laminaria digitata AY857921, L. sinclairii AY857920, and L. saccarina AB480844

Lessonia nigrescens $\mathrm{B} 858 \mathrm{~N}$, L. variegata/N B210, and L. variegata/W A001

Table A 2.9.3.8 HKY corrected distance of nd6-gene

$\begin{array}{llll} & \text { Ala } & \text { Lam } & \text { Les } \\ \text { Ala } & - & & \\ \text { Lam } & 0.121 & - & \\ \text { Les } & 0.142 & 0.155 & -\end{array}$

Average between group $=0.139$ 
Table A 2.9.3.9 Corrected divergence rate for nd6-gene in $\mathrm{My}^{-1}$

$\begin{array}{llll} & \min & \max & \text { mean } \\ \text { divergence rate } & 0.0105 & 0.0140 & 0.0123 \\ \text { mutation rate } & 0.0052 & 0.0070 & 0.0061\end{array}$

D5) ITS divergence rate

Samples used:

Alaria crassifolia AF319001

Laminaria digitata AF319014

Lessonia nigrescens $\mathrm{B} 858 \mathrm{~N}$, L. variegata/N B210, and L. variegata/W A001

Table A 2.9.3.10 HKY corrected distance of ITS

$\begin{array}{llll} & \text { Ala } & \text { Lam } & \text { Les } \\ \text { Ala } & - & & \\ \text { Lam } & 0.062 & - & \\ \text { Les } & 0.067 & 0.100 & -\end{array}$

Average between group $=0.076$

Table A 2.9.3.11 Corrected divergence rate for ITS in $\mathrm{My}^{-1}$

$\begin{array}{llll} & \min & \max & \text { mean } \\ \text { divergence rate } & 0.0057 & 0.0076 & 0.0067 \\ \text { mutation rate } & 0.0029 & 0.0038 & 0.0033\end{array}$

E) settings used in BEAST for calibration strategy C

Priors:

atp8.meanRate: normal, mean $=0.0115$, stdev $=0.0017$

trnW.meanRate: normal, mean $=0.0073$, stdev $=0.0010$

nd6. meanRate: $\quad$ normal, mean $=0.0061$, stdev $=0.0009$

rbc.meanRate: normal, mean $=0.0030$, stdev $=0.0004$

its.meanRate: normal, mean $=0.0033$, stdev $=0.0005$ 


\section{Chapter 3}

Phylogeography of Lessonia (Phaeophyceae, Laminariales) in Australasia

\subsection{Abstract}

A goal of phylogeography is to relate phylogenetic patterns to potential historic and contemporary geographic isolating events. Here I investigated the distribution of Australasian Lessonia, an important habitat forming algal genus found on most rocky shores around New Zealand, its Sub-Antarctic Islands, and Tasmania. Lessonia variegata, from the main islands of New Zealand, has recently been split into four species with previously undefined distributional boundaries. To a certain extent genetic breaks within a species may correlate to genetic breaks of other species. Breaks found more often in phylogeographic studies may denote boundaries of general biogeographic regions. My aim was (1) to compare the distribution of Lessonia with proposed bioregions and (2) to develop phylogeographic hypotheses to explain its present day distribution in Australasia. I used two markers, with different mutation rates to gain information of the phylogenetic history of Lessonia. The data revealed high phylogeographic structuring and reciprocal endemism for all Australasian Lessonia. I found localized distribution of all lineages within the $L$. variegata species complex. One lineage (L.variegata/N) is confined to the northern part of the North Island; L. variegata/W is found at the southeastern part of the North Island and, spanning Cook Strait, at the eastern part of Marlborough Sounds;

L. variegata/K is endemic to the northeastern part of the South Island; and $L$. 
variegata/S is restricted to the southern part of the South Island. No overlapping areas have been found. The data showed that genetic breaks in Lessonia do correlate to bioregions and highlight the importance of Cape Campbell at the northeast of the South Island, a well know phylogeographic break, as a barrier between adjacent North Island and South Island species. The species distribution also correlates to the geographic structuring of New Zealand during the Pliocene, 3.5 Mya.

Key Index Words: Australasia, bioregions, chloroplast marker, Lessonia, mitochondrial marker, New Zealand, Phaeophyceae, Phylogeography, Tasmania Abbreviations:atp8-sp, spacer region between atp dehydrogenase subunit 8 and tRNA serine; CTAB, Cetyltrimethylammonium Bromide; MJ, median joining; MP, maximum parsimony; My, million years; Mya, million years ago; rbc-sp, spacer between the large and short subunit of the ribulose-1,5-bisphosphate carboxylase/oxygenase gene; SSCP, Single stranded conformational polymorphism; 


\subsection{Introduction}

Lessonia Bory is a very young genus within the Phaeophyceae. Recent molecular studies (Chapter 2) have shown that the Australasian Lessonia (L. adamsiae Hay, L. brevifolia J.Agardh, L. corrugata Lucas, L. tholiformis Hay, and L. variegata J.Agardh) are a monophyletic group and have diverged during a rapid radiation $3.5-$ 3 million years ago (Mya). L. variegata, earlier believed to be a single species occupying the coasts of the three main islands of New Zealand, has been divided into a non-monophyletic species complex of four different lineages (Chapter 2). The full extent of their geographic distributions, however, is still unexplored.

New Zealand has had a complex geological history since being detached from Gondwana about 80 Mya (McLoughlin 2001). For the last 3.5My, the upper mean of the proposed time of speciation within Lessonia (Chapter 2), New Zealand was influenced by three major geological and climatic events: tectonic movements in conjunction with the Kaikoura Orogeny or Alpine Fault (King 2000); the changed sea levels and temperatures due to glacials and interglacials during the Pleistocene (Carter 2001); and volcanic activity especially in the lake Taupo area (Froggatt et al. 1986, Manville \& Wilson 2004). Each of these events alone or in combination with other events might have influenced the distribution and speciation/extinction of Lessonia populations in New Zealand.

A review of 42 molecular studies on the phylogeography of coastal marine invertebrates and plants undertaken in New Zealand between 1980 and 2008, revealed a multitude of phylogeographic breaks (Ross et al. 2009 and references herein). To develop biogeographic classification schemes scientists search for overall 
trends in taxa distribution (Shears et al. 2006, Ministry of Fisheries and Department of Conservation, 2008; hereafter called MPA 2008). One derived from a best fit on presence-absence data of macroalgae samples is given by Shears et al. 2006 (Fig. 3.1a). In their approach, Lessonia variegata was considered to be the only Lessonia species within the study area. Currently in use to protect New Zealands marine habitats is a classification approach based on fourteen biogeographic regions (MPA 2008) (Fig. 3.1b). This scheme assumes that physical habitats and ecosystems, if separated by enough space (100s to $1000 \mathrm{~s}$ of $\mathrm{kms}$ ), will contain different biological communities due to a combination of broad-scale factors. Such factors may include water temperature, oceanography, current dynamics, large-scale latitudinal gradients, climate or barriers to dispersal. As biogeographic classification schemes derive from a multitude of different techniques and taxa they do not necessarily overlap with phylogeographic surveys of single taxa (Ross et al. 2009), even though there is a theoretical link. None of the phylogeographic studies reviewed by Ross et al. (2009) was fully congruent with the bioregions proposed by Shears et al. (2008) or the one used by governmental agencies (MPA 2008). A reason might be that mechanisms that shape species assemblages are different to those that lead to genetic substructure of a single widespread species, and/or the use of markers in phylogeographic studies that evolve too slowly to detect recent structuring (Ross et al. 2009). However, two breaks are of special interest as they have been found frequently: One is the biogeographic break at East Cape between the Portland and Northeastern bioregions where eddies are believed to obstruct connectivity between adjacent populations (Moore 1949 \& 1961, Knox 1975, Nelson 1994, Walls 1995 and 2006, Francis 1996, Stevens \& Hogg 2004, Shears et al. 2008). The other is the phylogeographic division between North and South Island lineages at Cape Campbell. Upwelling south of 
Cape Campbell was initially postulated as the driving force (Apte \& Gardner 2002, Waters \& Roy 2004, Ayers \& Waters 2005) but a recalibration of the divergence time showed that the genetic breaks were older than the upwelling zone (Goldstien et al. 2006). Changes in the hydrography of the Cook Strait region during the late Pleistocene as a consequence of fluctuationg sea levels following the cycles of glaciation and deglaciation have been suggested as alternative causes (Goldstien $e t$ al. 2006). The phylogenetic break at Cape Campbell, which is indicated in the MPA (MPA 2008), was not evident in a recent classification scheme based on macroalgal data (Shears et al. 2008).

For the present study, populations from New Zealand's Sub-Antarctic Islands, the Chatham Islands and Tasmania/Australia have been sampled in addition to populations on the three main islands of New Zealand to cover the whole distribution range of Lessonia in Australasia. Only few molecular studies on the phylogeography of marine benthic taxa are known that incorporated the SubAntarctic Islands of New Zealand and the Chatham Islands (reviewed in Ross et al. 2009, e.g., Goldstien 2010). Species with a circum-Sub-Antarctic distribution and high dispersal ability have shown either no genetic diversity as in Macrocystis pyrifera (Macaya \& Zuccarello 2010) or high genetic variability in New Zealand and its Sub-Antarctic Islands as in Durvillaea antarctica (Fraser et al. 2009a). Affinity of Chatham Islands and Bounty Island haplotypes to North Island haplotypes was evident in the later study, and in Carpophyllum maschalocarpum (Buchanan \& Zuccarello 2010 submitted), the same haplotypes have been found on North Island and Chatham Islands. Even though the Chatham Islands are influenced from both the North and South Island (Wallis \& Trewick 2009), they are considered an own 
province, called Moriorian (Powell 1961). Powell (1961) also suggested Antipodean Province for the four Sub-Antarctic island groups, the Auckland Islands, Campbell Islands, Antipodes Islands, and Bounty Islands. The Snares, however, originally within the Antipodean Province, were later moved into the Forsterian Province covering the southern part of New Zealand from Otago Peninsula to Fiordland including Stewart Island (Fell 1953 in Powell 1961, Powell 1961, Knox 1975) and were finally dedicated an own province in the Marine Protected Areas Policy (MPA 2008).

Genetic structuring in the waters surrounding Tasmania has been found in the brown alga Durvillaea potatorum (Fraser et al. 2009b) showing two distinct lineages that might as well be reproductive isolated species corresponding to the Peronian (New South Wales) and Flindersian (west of Peronian) province, respectively.

The aim of this research is to correlate the distribution in Lessonia lineages to proposed bioregions and to study the distribution of Lessonia in Australasia. Here I investigate the distribution of all Australasian Lessonia with focus on the $L$. variegata species complex and discuss possible phylogeographic scenarios and speciation events. Therefore I compare the proposed timing of speciation events with the proposed timing of geological events as geological events might have triggered speciation. Knowledge of the distribution of Lessonia in Australasia might help to protect and conserve biodiversity, especially in the new discovered Lessonia species and their communities. 


\subsection{Material and Methods}

\subsubsection{Sampling}

A total of 500 individuals of Lessonia were collected in the intertidal or subtidal while free diving at 57 sites in New Zealand and Tasmania, Australia (Table 3.1). Collection sites in New Zealand have been selected to span all phylogeographic regions as identified by Shears et al. (2008) (Fig. 3.1a). Tissue $\left(2-3 \mathrm{~cm}^{2}\right)$ was collected near the transition zone at the base of the blade where the blade is youngest and free of epiphytes, patted dry and subsequently sealed in bags with silica gel.

\subsubsection{DNA extraction, amplification, SSCP and sequencing}

DNA extraction was performed with $0.5 \mathrm{~cm}^{2}$ of dried tissue using a modified CTAB protocol (Zuccarello \& Lokhorst 2005). For fast and easy grinding I attached the microfuge pestle to a cordless drill.

PCR amplification and PCR conditions of the mitochondrial spacer region between adenosine-tri-phosphate dehydrogenase subunit 8 and t-RNA serine (atp8Sp) and the chloroplast spacer between the large and short subunit of the ribulose1,5-bisphosphate carboxylase/oxygenase gene (rbc-sp) were performed as described in Chapter 2. The primers used have been reported in Voisin et al. (2005), Lane et al. (2006), and Chapter 2.

Different atp8-sp haplotypes among and within populations were separated by single strand conformation polymorphism (SSCP) (Zuccarello et al. 1999). The protocols for SSCP and silver staining are described in Buchanan \& Zuccarello (2010 submitted) and Bassam et al. (1991), respectively. Known haplotypes were run as identifier on each gel. Band patterns that deviate from the patterns of the 
known haplotypes were sequenced to recognize possible new atp8-sp haplotypes. Additionally, random atp8-sp samples were sequenced as a control for SSCP.

Sequencing was done commercially (Macrogen Inc. Seoul, South Korea) after the PCR products have been purified with ExoSAP-IT (USB, Cleveland, Ohio, USA). Atp8-sp sequences of 182 individuals were combined with SSCP patterns of 399 individuals for further calculations, and 81 individuals were processed with both methods to check SSCP reliability. Additionally 54 individuals were also sequenced with a marker for the rbc-sp region.

\subsubsection{Data analysis}

Forward and reverse sequences were assembled in 'STADEN package' (Staden et al. 2002) using the implementable programs PHRED (Ewing \& Green 1998), PHRAP (Green unpublished [http://bozeman.genome.washington.edu/phrap.docs/phrap.html]), and GAP4 (Bonfield et al. 1995). The alignment was performed in BIOEDIT ver. 7.0.9.0 (Hall 1999) using CLUSTALW 1.4 (Thompson et al. 1994) and was subsequently refined by eye as suggested in Sinclair et al. (2005).

Median joining (MJ) networks for the whole datasets (atp8-sp and rbc-sp) and separately for each species (atp8-sp) were calculated with NETWORK ver. 4.5.1.6 (Bandelt et al. 1999). Full median networks (showing all possible reticulations) were calculated for the rbc-sp network and for the single species atp8sp networks. A full median network is achieved when epsilon is greater or equal to the product of weighting and the maximum distance between the samples. However a full median network of the whole atp8-sp dataset would have been too memory extensive, thus a complex median network with epsilon=10 was calculated followed 
by a maximum parsimony (MP) calculation (Polzin et al. 2003), to remove nonparsimonious links.

Isolation by distance was determined using mantel test function in ARLEQUIN 3.11 (Excoffier et al. 2005) to compare alternative dispersal routes around Tasmania for L. corrugata.

\subsection{Results}

Signs of saturation were not apparent in the atp8-sp region. All SSCP banding and sequencing results were concordant. In the case of L. tholiformis, I identified four haplotypes via sequencing, based on three variable sites; however the differences in SSCP banding were too small to allow unambiguous identification. Nevertheless there have been no difficulties separating these samples from other Lessonia species.

The slow-evolving cl-DNA rbc-sp yielded a dataset of 363bp. This marker showed almost only variation between species with eight variable sites and two deletions, and only one uninformative mutation within L. variegata/N. The rbc-sp haplotypes of L. variegata/S and L. adamsiae were identical thus the rbc-sp is not suitable to distinguish between all Australasian species. Also identical were the haplotypes of two specimens of L. variegata/N (B099 and B210) with the single rbcsp haplotype of L. variegata/W. The remaining L. variegata/ $\mathrm{N}$ specimens differ by a shared 32bp deletion from the L. variegata/W haplotype (Table 3.2).

The faster evolving mt-DNA atp8-sp yielded a dataset of 133bp. To increase resolution, I included 40bp of the adjacent atp8-gene and 17bp of the downstream trnS-gene into an extended dataset of 190bp. There was no (L. adamsiae, $L$. brevifolia) to little (L.variegata/S, and L.variegata/K; 1 bp each) genetic variation in 
the southern Lessonia species and highest variation in the northernmost species $L$. variegata/N (6bp). The other species showed moderate variation (Table 3.2).

A full median rbc-sp network for all Lessonia was achieved with epsilon $=70$ showing a star shaped relationship (Fig. 3.2).A reduced median atp8-sp network of all Lessonia showed star like radiation in Australasia und was calculated with default settings (epsilon =0) in NETWORK (Fig. 3.3).

A full median atp8-sp network (epsilon>30) of L. variegata/W haplotypes revealed that two close related haplotypes are found in distant populations within its distribution range and less related haplotypes were found in an intermediate zone (Fig. 3.4).

The full median atp8-sp network (epsilon>50) of $L$. corrugata haplotypes showed a straight line with absolutely no reticulations and the least related haplotypes found in close proximity at Ladies Bay (site 57) and Hobart (site 56; Fig. 3.5). According to the atp8-sp network of all Australasian Lessonia species (Fig. 3.3) a root in Fig. 3.5 was determined at mc1. Based on the network and the distribution of the L. corrugata haplotypes two dispersal hypotheses were tested. One simulating isolation by distance along a the east coast $\left(\mathrm{H}_{\text {east }}\right)$, the other one isolation by distance all around Tasmania assuming the area between Ladies Bay and Hobart to be a secondary contact zone $\left(\mathrm{H}_{\text {west }}\right)$. The mantel test results indicated a better support for the hypothesis $\mathrm{H}_{\text {west }}$ with $\mathrm{r}^{2}$ west $=0.93, \mathrm{p}_{\text {west }}=0.006$ and $\mathrm{r}_{\text {east }}^{2}=0.13$, $\mathrm{p}_{\text {east }}=0.307$.

All eight Australasian Lessonia species (as defined in Chapter 2) showed a non-overlapping distribution (i.e., endemism) (Fig. 3.6). Lessonia variegata/ $\mathrm{N}$ is found in the "Raglan" and "Northeastern" bioregions (regions and provinces after 
Shears et al. 2008, Fig. 3.1a) from Hokianga (site 1) around North Cape to Lottin Point/East Cape (site 16). A sharp genetic break was found at East Cape between Lottin Point and Horoera (site 16 and site 17) ( 30 km apart) dividing the $L$. variegata/N from L. variegata/W. Lessonia variegata/W was found south of Horoera (site 17) all along the southeast coast of the North Island to Whites Bay (Marlborough Sounds / South Island; site 26), spanning Cook Strait. Southward $L$. variegata/K was solely found between Cape Campbell (site 27) and Paia Point (site 32; $17 \mathrm{~km}$ south of Kaikoura). Lessonia variegata/S was found south from Tumbledown Bay (site 33; Banks Peninsula) to Doubtful Sound (site 39; Fiordland) including Stewart Island (site 38). Lessonia brevifolia is found on Auckland Islands (site 42), Campbell Islands (site 43), Antipodes Islands (site 44), and Bounty Islands (site 45), and L. adamsiae is endemic to The Snares (sites 40 and 41). Lessonia tholiformis and L. corrugata are endemic to the Chatham Islands (sites 46-50; Fig. 3.6) and to Tasmania (sites 52-57; Fig. 3.5), respectively.

\subsection{Discussion}

Recent research (Chapter 2) had split L. variegata into four species with yet unknown distribution limits. This survey evaluates the applicability of bioregions (Fig. 3.1) to the distribution of Lessonia species with emphasis to the Lessonia variegata species complex (Fig. 3.6) and tries to explain biogeographic distribution of all Australasian Lessonia species in a phylogeographic framework. For biogeographic interpretation, I used two markers with different mutation rates that allow insight into different time frames (Verbruggen \& Theriot 2008) with a slow evolving marker (rbc-sp) for relationships between species (3.5-3 Mya) and a faster evolving marker (atp8-sp) for relationships within species (Chapter 2). 


\subsubsection{Distribution and Bioregions}

Extensive sampling was undertaken to determine distribution limits and to assess correlation to proposed bioregions. The results show local endemism for all Australasian Lessonia (Fig. 3.5-3.6) including the four recently proposed cryptic species within the Lessonia variegata species complex (Chapter 2). Overall the genetic breaks or species boundaries found in Lessonia correspond well to the proposed biogeographic classifications after Shears et al. (2008) and MPA (2008).

L. variegata/ $\mathrm{N}$ is found throughout the Northeastern bioregion but on the western boundary it was found as far south as Hokianga (site 1, Fig. 3.6). Lessonia populations have been reported as far south as Auckland region on the western coast of the North Island (Auckland Museum records). On the eastern side a sharp genetic break between L. variegata/N and L. variegata/W (sites 16 and 17, respectively) corresponds to the break between the Northeastern and Portland bioregion. This break has been identified in a multitude of biogeographic classification schemes (Moore 1949, Knox 1975, Walls 1995 and 2006, Nelson 1994, Francis 1996, Shears et al. 2008) and phylogeographic surveys (Apte \& Gardner 2002, Stevens \& Hogg 2004, Waters \& Roy 2004, Ayers \& Waters 2005), and is probably the most detected biogeographic break in the marine realm around New Zealand. The break is generally attributed to the permanent and anticyclonic East Cape Eddy that captures most of the south east flowing East Auckland current (Stanton et al. 1997) and is thus believed to be a significant barrier to gene flow (e.g., Stevens \& Hogg 2004). Despite the retention effect of the East Cape Eddy, temperature differences between the warm subtropical East Auckland Current and the cool northward flowing 
Wairarapa Current, which meet at East Cape (Chiswell 2000), might also maintain species boundaries.

L. variegata/W is found throughout Portland and the northern half of the Cook bioregion. The break between Portland and Cook bioregion was detected as a transition zone between two different $L$. variegata/W haplotypes (Fig. 3.4). In discrepancy to Shears et al. (2008) but in concordance to MPA (2008) I found a genetic break at Cape Campbell between L.variegata/W and L. variegata/K. In the Cook Strait area, only a combination of the two classification schemes seems to embrace the distribution of Lessonia lineages. Whereas Shears et al. (2008) divided the Cook Strait into a western and eastern region (Abel and Cook), MPA (2008) used a north to south division (North and South Cook Strait) (Fig. 3.1). However, with the addition of a break at Cape Campbell my data is better represented with a west to east division as no Lessonia have been found in Abel bioregion and L. variegata/W is found on both sides of Cook Strait. A break near Cape Campbell was previously found in a biogeographic survey of 375 reef fish (Francis 1996) as well as in several phylogeographic surveys (Apte \& Gardner 2002; Perna canaliculus, Schnabel et al. 2000 and Stevens \& Hogg 2004; southern limit of Paracorophium lucasi, Waters \&Roy 2004, and Ayers \& Waters 2005; Patiriella regularis, Goldstien et al. 2006; Cellana ornata). The actual location of the break, however, was unknown or differed between the taxa surveyed and so the explanations differed. Whereas some suggested upwelling as a possible differentiating force (e.g., Apte \& Gardner 2002, Waters \&Roy 2004, and Ayers \& Waters 2005), or favoured currents and eddies (e.g., Stevens \& Hogg 2004) others suggested that changes in the dynamic hydrography of Cook Strait triggered differenciaton while dismissing upwelling as a possible reason 
(Goldstien et al. 2006). A recalibration showed that the postglacial upwelling south of Cape Campbell originated long after the genetic differentiation found in Perna canaliclus and Patiriella regularis (Goldstien et al. 2006). Upwelling can not be stressed as a factor separating the two Lessonia lineages either, as L. variegata/K is found across the area of upwelling till Cape Campbell. Whether currents and eddies are a likely barrier is not known, but whatever the reason the break between $L$. variegata/W and L. variegata/K is supported by a natural border, which is the marshlands of two successive river deltas that separates the different lineages (along a distance of more then $40 \mathrm{~km})$.

L. variegata/K is solely found in the southern part of the Cook bioregion from Cape Campbell (site 27, Fig. 3.6) till Goose Bay (site 32). Whereas upwelling cannot explain the break between $L$. variegata/W and L. variegata/K it might be the reason for a unique haplotype within the $L$. variegata/K lineage that is only found at Cape Campbell. The southern limit of L. variegata/K corresponds to the break between Cook and Banks bioregion. Again, the distribution of L. variegata/K fits best to a combination of the biogeographic classification scheme after Shears et al. (2008) and MPA (2008), with a better fit to Shears et al. (2008) in the south and to MPA (2008) in the north.

L. variegata/S is distributed from Chalmers over Stewart Island to Fiordland bioregions. No Lessonia was found along the sandy areas that characterise the majority of the Banks bioregion but for a population on Banks peninsula (site 33). As this population is more than $200 \mathrm{~km}$ north of its nearest neighbour, it is possibly better described as a satellite population than as the northern boundary of the species distribution (Fig. 3.6). 
No Lessonia was found in this study on the west side of New Zealand (e.g., Westland, Buller, Able, and Raglan) despite records of scattered populations [Westland: Open Bay Island (Neale \& Nelson 1998) (site R1, Fig. 3.1); Raglan: Maori Bay and O’Neill Bay (Auckland Museum records) (site R2)].

The other four species are endemic and confined to bioregions that are composed of one or more islands, i.e., L. adamsiae is endemic to The Snares, which is given it's own bioregion after MPA (2008) but was before assigned to the Forsterian Province; L. brevifolia is restricted to the Sub-Antarctic Islands bioregion (Antipodes, Auckland Islands, Bounty Islands, and Campbell Islands); L. tholiformis is only found on the Chatham Islands; and L. corrugata is endemic to Tasmania.

The phylogeographic breaks in Lessonia generally correspond well to the proposed biogeographic schemes of both Shears et al. (2008) and the MPA (2008). In the Cook Strait area only a combination of the two classification schemes is supported by the distribution boundaries of Lessonia. The east to west division of the Cook Strait as proposed in Shears et al. (2008) corresponds better to the distribution of Lessonia than a north to south split as proposed in the MPA (2008). A break at Cape Campbell, on the other side, was not recognised by Shears et al. (2008) but was by the MPA (2008). In the MPA (2008) no biogeographic break was made to separate the sandy areas of Canterbury Bight and Pegasus Bay from the rocky coastline north of Pegasus Bay. This break was proposed by Shears et al. (2008) and also evident in Lessonia. An east to west devision of the Cook Strait as in Shears et al. (2008), a break at Cape Campbell as in the MPA (2008), and a split north of Pegasus Bay as in Shears et al. (2008) would possibly be a beneficial combination of the two proposed classification schemes as it appears in the case of Lessonia. 


\subsubsection{Phylogeography}

\subsubsection{Ancient component (relationships between species and speciation)}

My results reveal high phylogeographic structure and local endemism in Lessonia.

All Lessonia species in Australasia, including the four species within the $L$.

variegata species complex, are confined to a certain area with no overlapping in their distribution (Fig. 3.5-3.6). While there is high phylogeographic and phylogenetic structure there is little phylogenetic resolution in Lessonia. This is often coupled with star radiation (Fig. 3.2 and 3.3) and was found to be a common pattern in phylogeographic studies of terrestrial plants and animals in New Zealand (Wallis \& Trewick 2009 and references herein). In the terrestrial realm, the tectonic uplift in the Pliocene and the resulting emergence of the Southern Alps was reasoned to have created conditions for rapid radiation (Wallis \& Trewick 2009). In Chapter 2, I suggested that rapid radiation in the Australasian Lessonia that took place 3.5-3 Mya and the outline of Pliocene New Zealand might have offered suitable conditions (Fig. 3.7). The time of sudden radiation is often indicative of dramatic change in the history of a species e.g., the time of colonisation into a new area via long distance dispersal (Carranza et al. 2000, Waters \& Roy 2004b, Thiel \& Haye 2006). In the case of Lessonia, this might be as well the time it arrived in Australasia.

Standard bifurcation tree approaches are not able to deal with real star like evolutionary relationships, nor can trees account for internal haplotypes; here networks are able to give a more realistic representation (e.g., Sinclair et al. 2005).

On the other side networks are normally not rooted which leads to lacking information about the direction of evolution. Here we could use the close relationship of the Australasian ingroup to the South American L. vadosa (Chapter 2) 
to infere the root of the atp8-sp and rbc-sp networks. The networks (Fig. 3.2 and 3.3) revealed star like phylogeny in Australasia, which supports the assumption of rapid radiation (Hundertmark et al. 2003) in Lessonia. The rbc-network (Fig. 3.2) suggests an ancient relationship of $L$. variegata/N to an ancestral L. variegata/W haplotype, due to the low mutation rate of the rbc-marker (Chapter 2). Geographic isolation might have led to divergent evolution in $L$. variegata/N and L. variegata/W. The rbc-sp network suggests that $L$. variegata/W is ancestral to $L$. variegata/N. At the time of radiation in Lessonia (mid to late Pliocene), the central and southern part of the North Island was mainly submerged and a big ridge emerged through uplift possibly spanning from Cape Palliser to Cape Kidnappers (Fig. 3.7E, Lewis et al. 1994, Bunce et al. 2009). Whereas the west coast of this ridge has undergone dramatic changes, the east cost has not changed much since its emergence, resembling today the biggest part of the distribution area of L. variegata/W. L. variegata/W possibly has its origin on this ridge before it became later connected to northern North Island by bridging the Manawatu Strait through further tectonic uplift 1 Mya (Bunce et al. 2009; fig. S3). Today's distribution of L. variegata/W spans from East Cape (site 17, Fig. 3.6) to Whites Bay (site 26, southeast Marlborough Sounds). The East Cape Eddy would have maintained separation between the two North Island species even after the closure of the Manawatu Strait if it was not acting as a barrier already.

Apart from L. variegata/W on the east coast of the Marlborough Sounds, two additional Lessonia species are found on the South Island. One, L. variegata/K is endemic to the northeast from Cape Campbell to Paia Point. As pointed out above, peripatric speciation of L. variegata/W on an early Pleistocene island is likely thus 
vicariance (e.g., formation of Cook Strait) has not created diversification between a possible common ancestor of $L$. variegata/W and $/ \mathrm{K}$, especially as the timing of radiation predates the timing of Cook Strait formation. Later during glacial periods of the Pleistocene, Cook Strait was closed and land emerged due to decreasing sea levels (e.g., Fleming 1979). Thus, without invoking passive rafting as a means of dispersal, the bridging of Cook Strait from north to south by L. variegata/W was possible during glacial periods given suitable habitat have had emerged with decreasing sea levels.

On its southern limit L. variegata/K is separated from $L$. variegata/S by a $>350 \mathrm{~km}$ gap of quaternary sediment. This gap formed by glacial outwash and aggradations with the retreat of the first ice age of the Pleistocene and has persisted during glacial and interglacial period ever since (Fig. 3.6-3.7B, Fleming 1979). Sandy beaches and soft sandstones are unsuitable habitat for Lessonia (personal observation) and no Lessonia was found in Pegasus Bay and Canterbury Bight. Based on a survey of L. nigrescens, Faugeron et al. (2005) suggested that the normal dispersal potential in Lessonia is low, with recruitments normally found in the vicinity of the parent. Thus the gap was probably big enough to prevent connectivity and enabled divergent evolution between the two South Island species.

Lessonia adamsiae shows relatedness to either L. variegata/S (rbc-sp, Fig. 3.2) or L. corrugata (atp8-sp, Fig. 3.3). However, the atp8-sp is a fast evolving marker whereas rbc-sp is slower evolving (Chapter 2) the latter thus revealing the older phylogenetic history. The use of both fast and slow evolving markers might help to pinpoint a more accurate understanding of historical events in the evolution of a species. A hypothesis derived from the combination of the two markers is that 
the radiation of Lessonia in paleo-Australasia (starting $~ 3.5 \mathrm{Mya}$ ) also included colonisation of Tasmania, initiating peripatric speciation of L. corrugata. The finding that the slow evolving marker shows no difference between L. adamsiae and L. variegata/S, whereas the faster evolving marker shows a closer relationship between L. adamsiae and L. corrugata is interpreted here as a speciation event through hybridisation. In this scenario hybridisation took place between an ancestor of L. variegata/S on the one hand and L. corrugata specimen dispersing from Tasmania to New Zealand on the other hand. The hybridisation event would have been ancient ( 2 Mya) with L. adamsiae on The Snares as the descendent.

The data show endemic status for all Australasian Lessonia species to their respective islands or regions. No overlapping distribution ranges have been found in Australasia, which is in strong contrast to the situation in South America and Falkland Islands (Searles 1978, Edding et al. 1994).

\subsubsection{Recent component (phylogeographic structure within species)}

The faster evolving atp8-sp was used on three examples (L. corrugata, $L$. variegata/W and L. brevifolia) to gain information on the phylogeographic structure within species.

Genetic divergence was also found within L. corrugata. A geographic mapping of the atp8-sp network, whose root position was determined using $L$. adamsiae as outgroup, revealed that the least related haplotypes are found in close proximity at Ladies Bay and Hobart (Fig. 3.5). A scenario previously described for the western clade of Durvillaea potatorum (Fraser et al. 2009b) can be used to explain this contradiction. Following Fraser et al. (2009b), a putative glacial refugium might have existed northwest off Tasmania where cold Sub-Antarctic 
water was pushed further north by a deflected subtropical convergence translocating the northern range of the cold water adapted L. corrugata. Assuming that this refugium was the origin for all recent $L$. corrugata new postglacial coastal pathways and redirected currents might have allowed for two different dispersal routes around Tasmania: one going east through the reopened Bass Straight and then south following the East Australian current; the other along the west coast following the Zeehan current. The area between Ladies Bay and Hobart, where the least related haplotypes have been found in close proximity, is supposedly a secondary contact zone. To compare this hypothesis $\left(\mathrm{H}_{\text {west }}\right)$ with a correlation based only on the geographic distance between the populations on the east coast (e.g., without a connection between Ladies Bay and Skeleton Bay through Bass Straight $)\left(\mathrm{H}_{\text {east }}\right)$, I performed two different Mantel test analyses. The better fit of the correlation coefficient for $\mathrm{H}_{\text {west }}\left(\mathrm{r}^{2}{ }_{\text {west }}=0.93, \mathrm{p}_{\text {west }}=0.006 ; \mathrm{r}_{\text {east }}=0.13, \mathrm{p}_{\text {east }}=0.307\right)$ supports the idea of a single north-western refugium (Fig. S 3.1). However hypothesis $\mathrm{H}_{\text {west }}$ has to be confirmed with a larger sample size. Ideally the predicted haplotypes mc1 and/or mc2 (Fig. 3.5) should be found in populations on the west side of Tasmania to verify this scenario.

While plotting L. variegata/W atp8-sp haplotypes on a map (Fig. 3.4), I found distant populations at East Cape and Whites Bay with closely related haplotypes, whereas in geographically intermediate populations I found haplotypes that are not directly related. This pattern can be explained with secondary contact of formerly separated populations. Since the middle Pleistocene (1 Mya), volcanic outfall regularly affected the west coast of the North Island (e.g., Froggatt et al. 1986, Newnham et al. 1999, Coleman et al. 2001, Manville \& Wilson 2004). 
Ignimbrite and/or tephra of eruptions in the Taupo volcanic zone might have created situations of reoccurring isolation for Lessonia populations at East Cape. Based on the data, I assume that isolation has caused the divergent evolution within $L$. variegata/W. Southward dispersal of derived East Cape-haplotypes driven by the East Cape Current and northward dispersal of Wellington-haplotypes driven by the Wairarapa Coastal Current has led to a contact zone at the border of two Biogeographic Provinces, Portland and Cook (Fig. 3.4).

Lessonia brevifolia most likely originated during radiation in Australasia as a result of peripatric speciation on one of New Zealand's Sub-Antarctic Islands; however the finding of no genetic variation between the distant islands $(>700 \mathrm{~km}$ between Campbell and Antipodes, which is the maximum of the shortest distances between islands) indicates a single glacial refugium. Model simulations (Chiswell 2009) would suggest the Auckland Islands as the most likely source for post glacial colonisation of Campbell Islands, Antipodes Islands, and Bounty Island. 


\subsection{Figures and Tables}

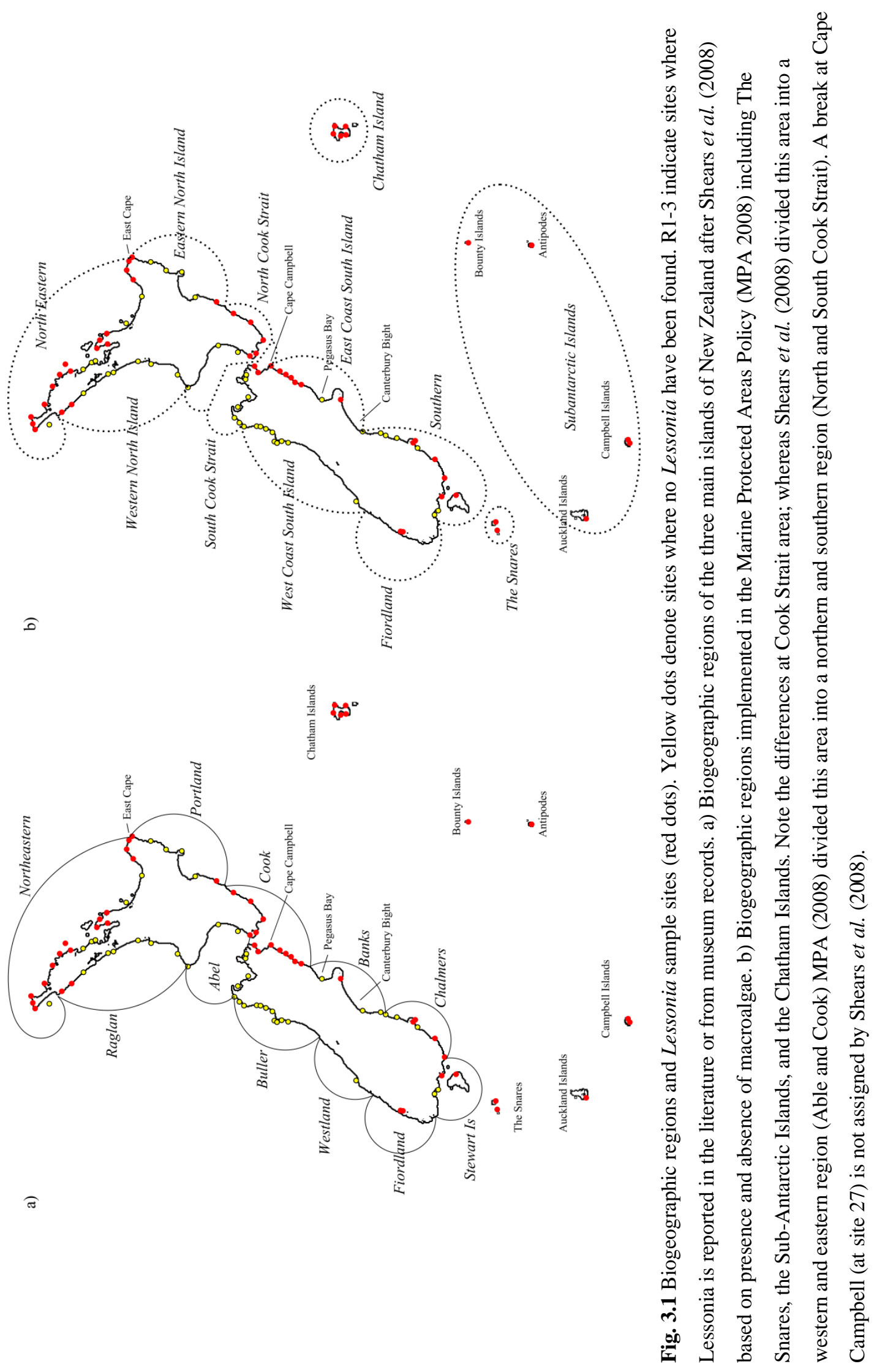




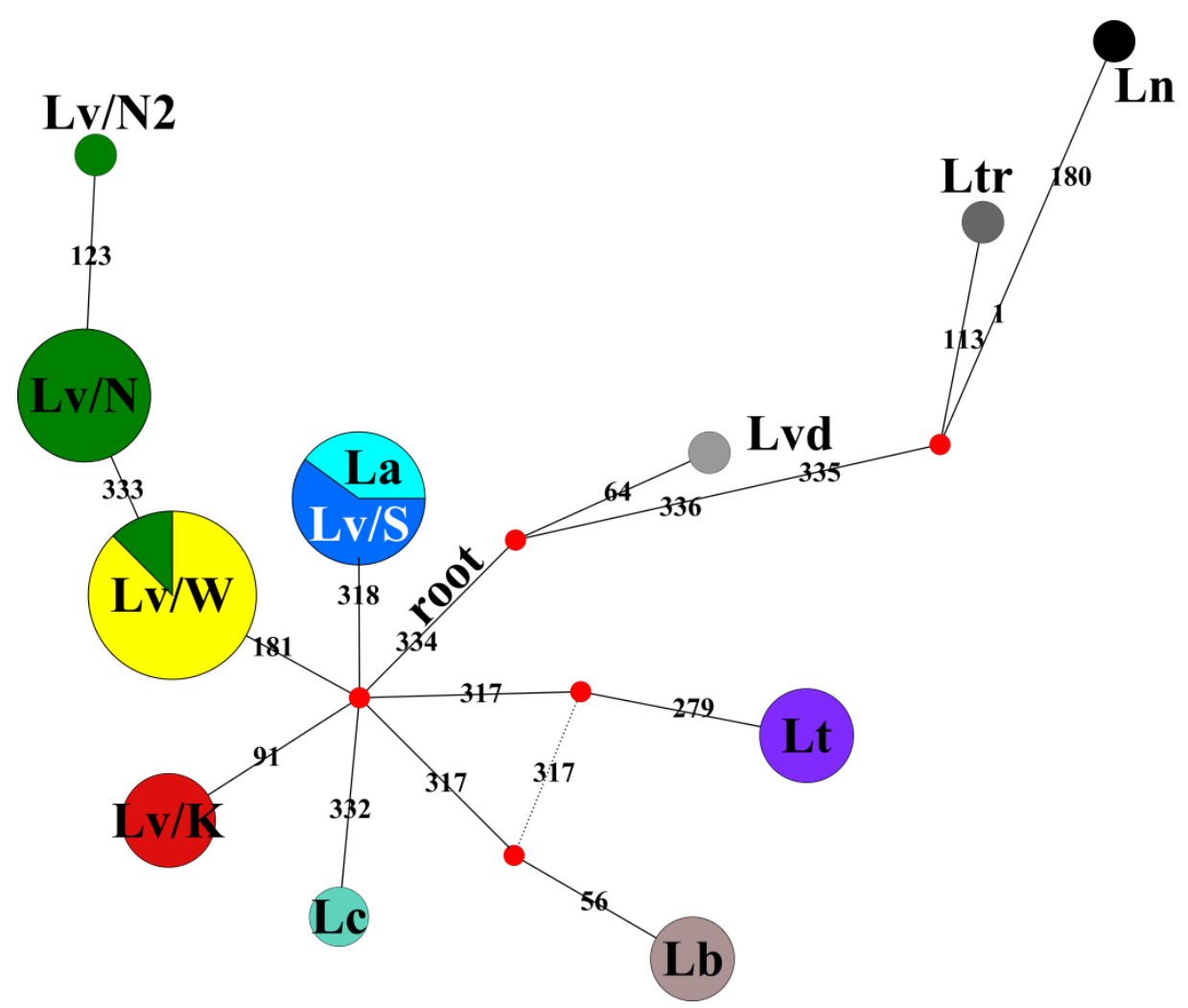

Fig. 3.2 Full median network (e=70) of the rbc-sp region showing star like evolution and ancient relationships among Australasian Lessonia. The network is rooted on South American species $(L$. nigrescens (Ln), L. trabeculata (Ltr), and L. vadosa (Lvd)). All samples from L. variegata/S (Lv/S) and $L$. adamsiae (La) share the same haplotype as do L. variegata/W (Lv/W) and two samples of $L$. variegata/N (Lv/N) (see Table 3.1). Lb L. brevifolia, Lc L. corrugata, Lv/K L. variegata/K, and Lt $L$. tholiformis. 


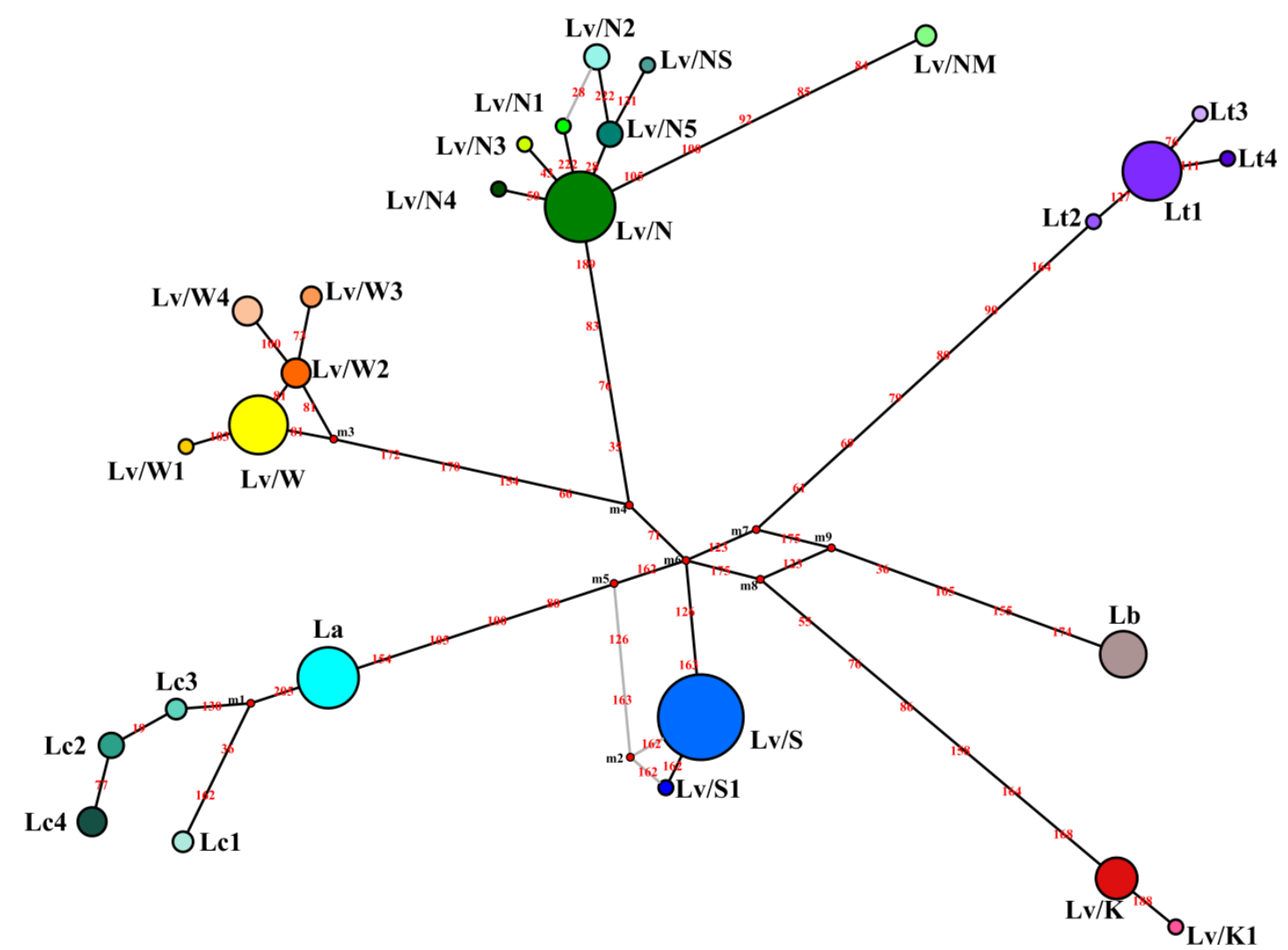

Fig. 3.3 Reduced median network of the atp8-sp region showing star like evolution within Australasian Lessonia. L. adamsiae (La) has an atp8-sp haplotype that is ancestral to L. corrugata (Lc) haplotypes. For the distribution of the haplotypes within Tasmania and New Zealand see Fig. 3.5 and 3.6 respectively. Lb L. brevifolia, Lt L. tholiformis, Lv/K L. variegata/K, Lv/N L. variegata/N, Lv/S L. variegata/S, and. Lv/W L. variegata/W. 


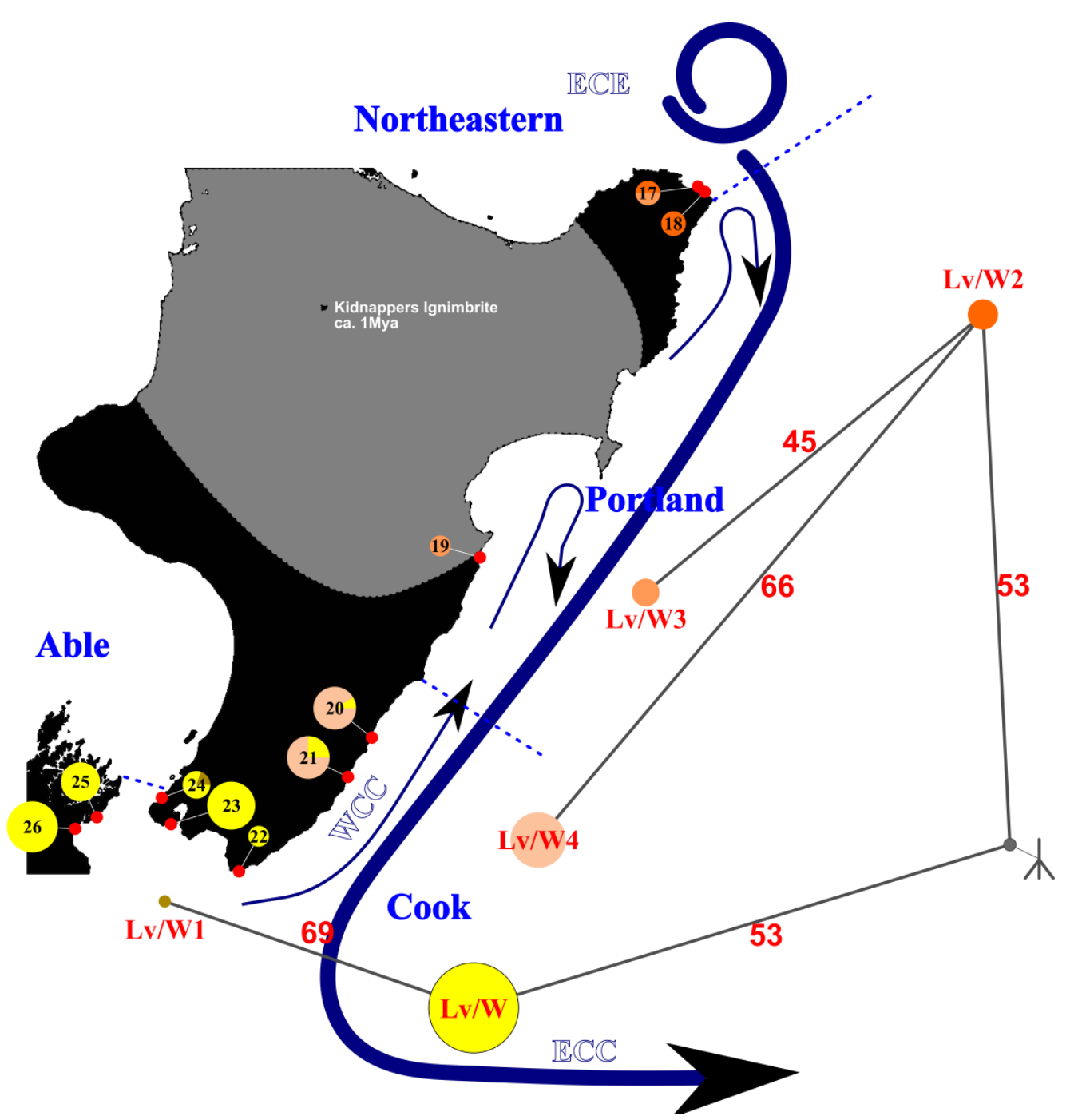

Fig. 3.4 Haplotype distribution and atp8-sp network of L. variegata/W showing the relationship between haplotypes. Tripod indicates root position. Two closely related haplotypes (Lv/W and Lv/W2) are found geographically far apart at either the East Cape or throughout Cook biogeographic region. Recent southward dispersal of Lv/W3 and Lv/W4 haplotypes following the East Cape Current (ECC) is suggested. Lv/W haplotypes were found at sites 20 to 26 with increasing abundance in the Cook Strait area. Northward dispersal following the Wairarapa Coastal Current (WCC) is likely. Lv/W1 was only found at site 24. The East Cape Eddy (ECE) is thought to act as barrier for gene flow between Portland and Northeastern bioregion. The grey area in the centre of the North Island illustrates the cover of ignimbrite after the Kidnapper eruption 1 Mya (after Wilson et al. 1995). Site numbers correspond to the sites in Table 3.1. 


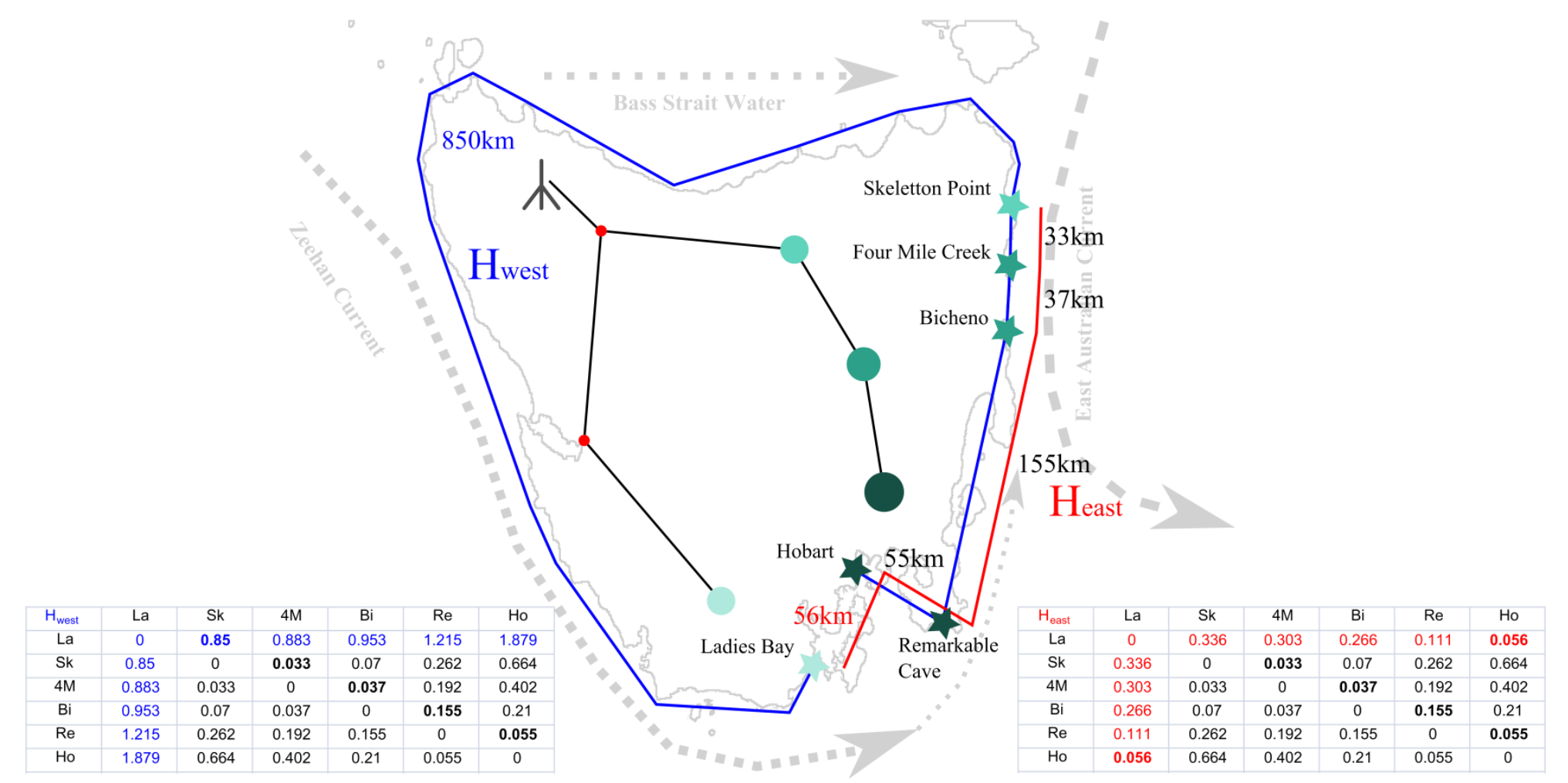

Fig. 3.5 Sample sites, haplotype distribution map and atp8-sp network of L. corrugata. Tripod indicates root position (this network is part of an Australasian network showing only the L. corrugata haplotypes, thus it is rooted). Two unrelated haplotypes are found in close proximity at Ladies Bay and Hobart. Two dispersal hypotheses have been tested, $\mathrm{H}_{\text {west }}$ (blue) and $\mathrm{H}_{\text {east }}$ (red). The two tested matrices differ in the geographic distance (colour coded) based on the dispersal hypotheses. A mantel test correlation coefficient supports $\mathrm{H}_{\text {west }}$ (with $\mathrm{r}_{\text {west }}^{2}=0.93, \mathrm{p}_{\text {west }}=0.006 ; \mathrm{r}_{\text {east }}^{2}=0.13, \mathrm{p}_{\text {east }}=0.307$ ). The haplotype distribution fits an explanation where out of a north western refugia L. corrugata dispersed at either side of Tasmania following the Zeehan Current or the Bass Strait Waters and East Australian current respectively (Bass Strait Current after Gibbs 1992). 


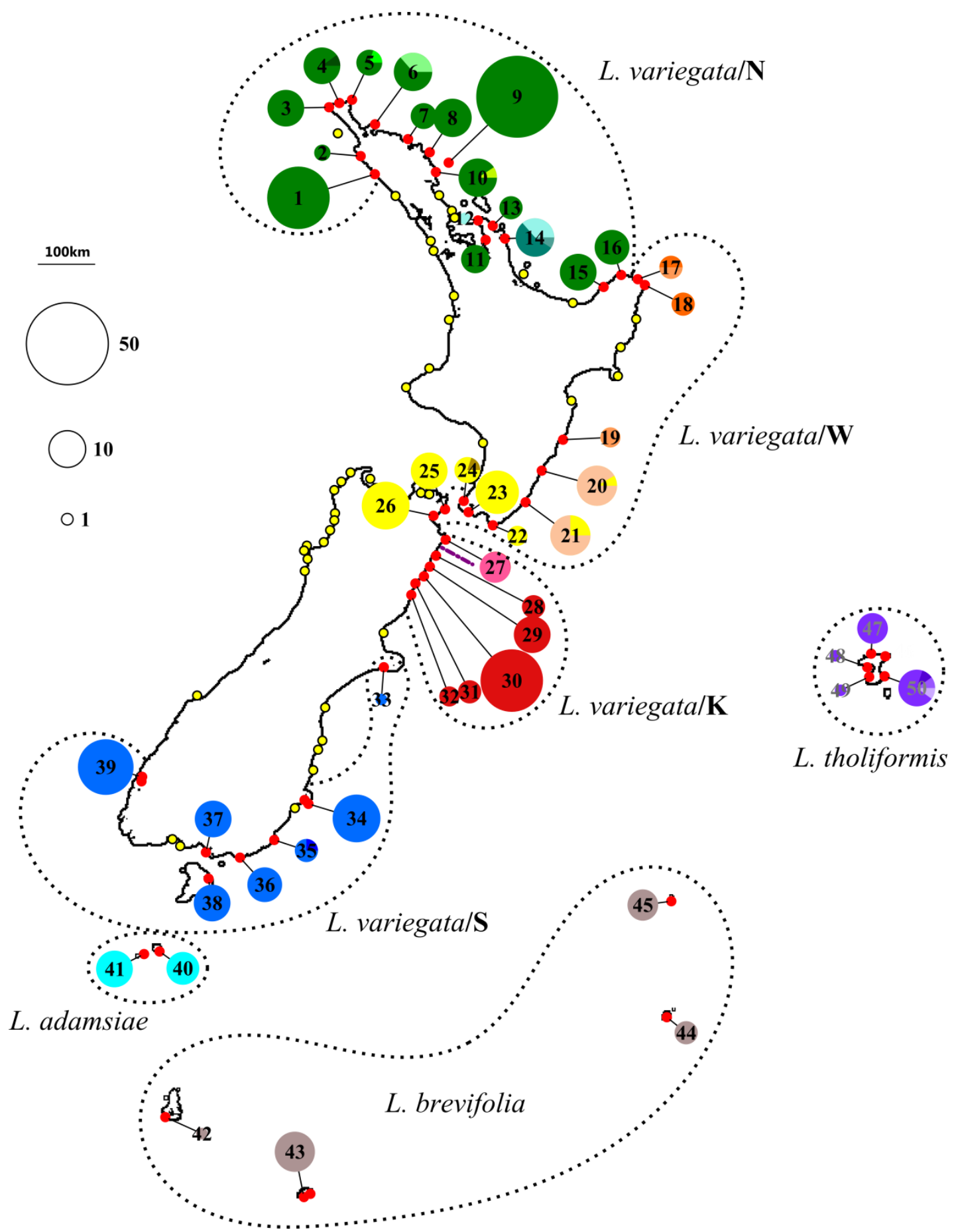

Fig. 3.6 Atp8-sp haplotype distribution map. Circle size proportional to sample size (see size standard on the left) numbers in circles are sample site ID's. Purple line between site 27 (Cape Campbell) and 28 (Kekerengu) denotes area of upwelling. Species ranges are indicated by dotted lines. 


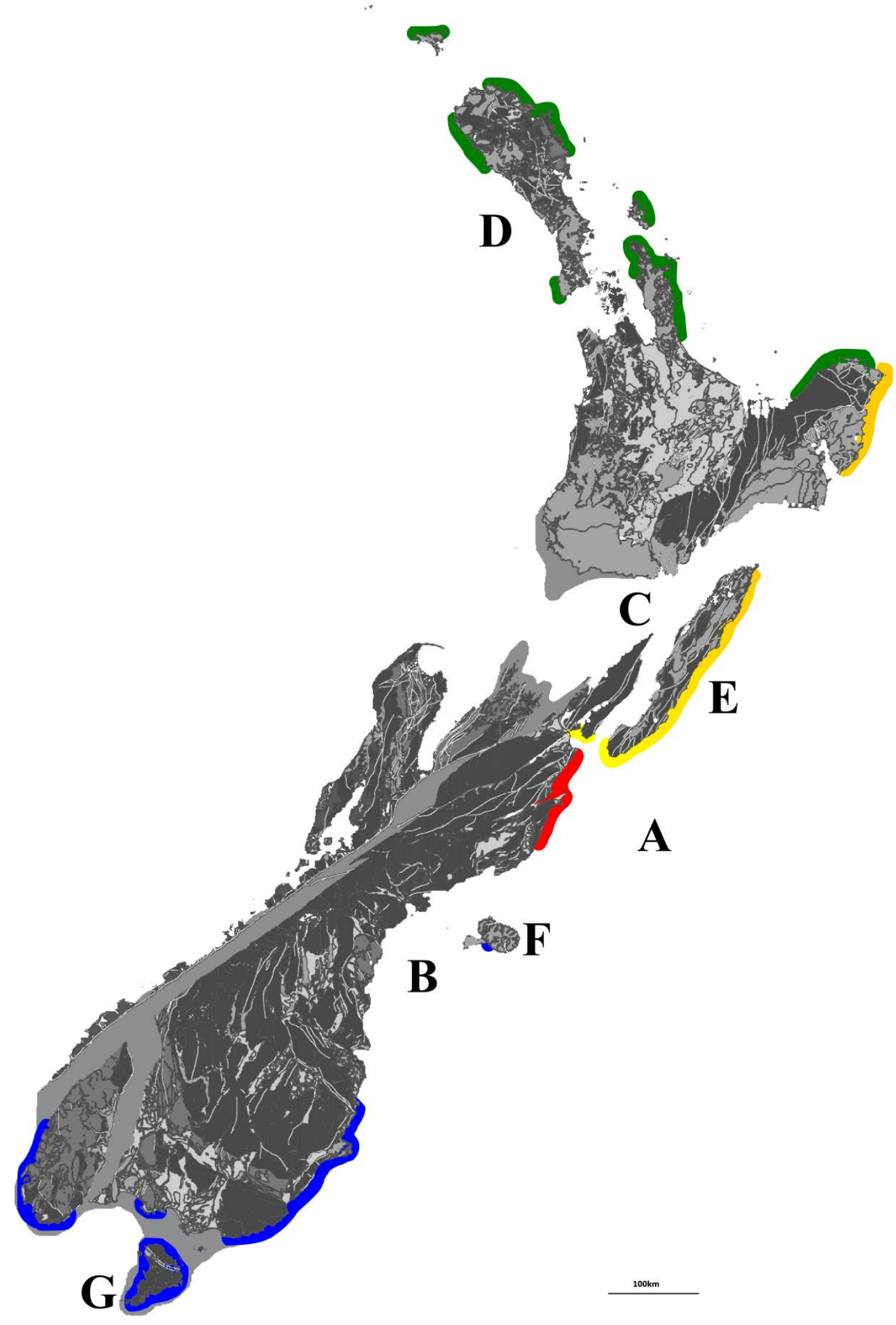

Fig. 3.7 New Zealand at the Late Pliocene. Coloured lines show the current distribution of Lessonia variegata lineages. Green $L$. variegata/N, yellow/orange $L$. variegata/W, red $L$. variegata/K, and blue L. variegata/S. A) Plate movement ( 30km/My) leading to the Kaikoura Orogeny (King 2000) and 
the opening of Cook Strait (Lewis et al. 1994, Bruce 2009). B) With the retreat of the first ice age of the Pleistocene, the Canterbury Plains have been formed through glacial outwash and aggradations. They persisted during any subsequent glacial and interglacial period (Fleming 1979). C) The lower part of the North Island was submerged during the Pleistocene (e.g., Fleming 1979; fig. 19). D) Northland was a chain of unconnected islands (e.g., Fleming 1979; fig. 19). E) The south eastern part of the North Island was a long stretched island, neither connected to the rest of the North Island nor to the South Island (Lewis et al. 1994, Bruce 2009). F) Banks peninsula was a volcanic island (e.g., Fleming 1979, Stevens et al. 1995). G) In the south, Stewart Island was connected with the South Island and The Snares were either connected or very close to the mainland (e.g., Stevens 1980; fig. 16.36). Not shown) The Sub-Antarctic Islands were all present; three were of volcanic origin and the youngest was active till 1 Mya (Peat 2003). The rocks of the Chatham Islands can be dated to 130 Mya, however, they have been submerged during the Pliocene till 2-3 Mya (Holt 2008). 
Table 3.1 Sample sites with coordinates (Lat. And Long.) and number (N) of atp8-sp and rbc-sp haplotypes $(\mathrm{H})$, respectively. $\mathrm{X}$ in $\mathrm{LtX}$ indicates that the concrete L. tholiformis haplotype is not known, due to insufficient resolution with SSCP.

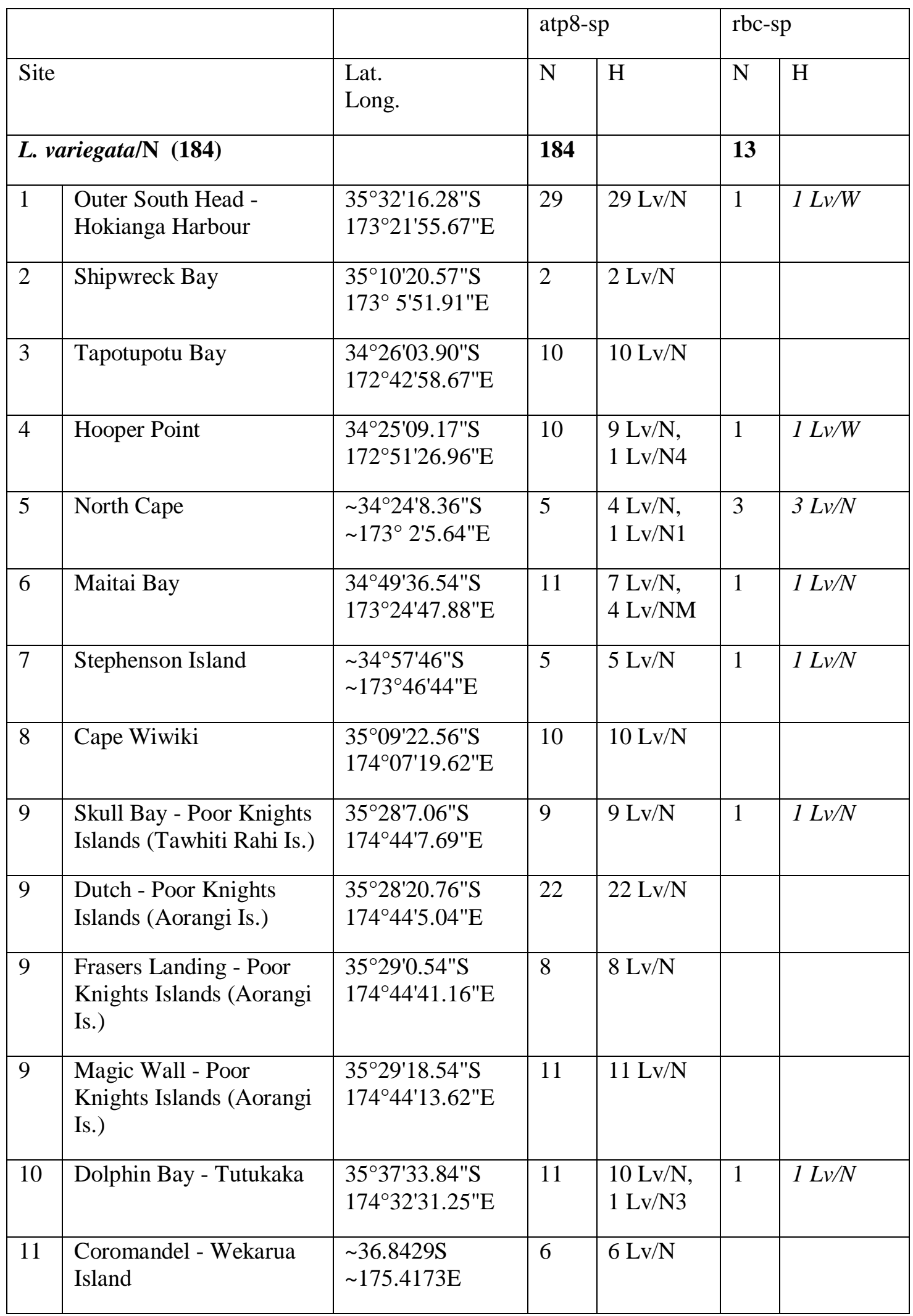




\begin{tabular}{|c|c|c|c|c|c|c|}
\hline 12 & $\begin{array}{l}\text { Coromandel - Fletcher } \\
\text { Bay }\end{array}$ & $\begin{array}{l}36^{\circ} 28^{\prime} 27.28^{\prime \prime S} \\
\sim 175^{\circ} 23 ' 32.61 " \mathrm{E}\end{array}$ & 1 & $\begin{array}{l}0 \mathrm{Lv} / \mathrm{N} \\
1 \mathrm{Lv} / \mathrm{N} 2\end{array}$ & 1 & $1 \mathrm{Lv} / \mathrm{N} 2$ \\
\hline 13 & $\begin{array}{l}\text { Coromandel - Waikawau } \\
\text { Bay }\end{array}$ & $\begin{array}{l}\sim 36^{\circ} 36^{\prime} 0.64 " \mathrm{~S} \\
\sim 175^{\circ} 32^{\prime} 25.56^{\prime \prime} \mathrm{E}\end{array}$ & 4 & $4 \mathrm{Lv} / \mathrm{N}$ & & \\
\hline 14 & $\begin{array}{l}\text { Coromandel - The Sailors } \\
\text { Grave }\end{array}$ & $\begin{array}{l}36^{\circ} 57^{\prime} 39.33 " \mathrm{~S} \\
175^{\circ} 50^{\prime} 41.36^{\prime \prime} \mathrm{E}\end{array}$ & 11 & $\begin{array}{l}0 \mathrm{Lv} / \mathrm{N} \\
4 \mathrm{Lv} / \mathrm{N} 2 \\
6 \mathrm{Lv} / \mathrm{N} 5 \\
1 \mathrm{Lv} / \mathrm{NS}\end{array}$ & 3 & $3 \mathrm{Lv} / \mathrm{N}$ \\
\hline 15 & $\begin{array}{l}\text { EastCape - Maraehako } \\
\text { Bay }\end{array}$ & $\begin{array}{l}37^{\circ} 43^{\prime 2} 29.99 " \mathrm{~S} \\
\sim 1^{\circ} 47^{\circ} 41.91^{\prime \prime} \mathrm{E}\end{array}$ & 10 & $10 \mathrm{Lv} / \mathrm{N}$ & & \\
\hline 16 & $\begin{array}{l}\text { EastCape - Lottin Point } \\
\text { Road }\end{array}$ & $\begin{array}{l}37^{\circ} 31^{\prime} 58.88^{\prime \prime S} \\
\sim 178^{\circ} 10^{\prime} 20.61 " \mathrm{E}\end{array}$ & 9 & $9 \mathrm{Lv} / \mathrm{N}$ & & \\
\hline \multicolumn{2}{|c|}{ L. variegata/W (85) } & & 85 & & 14 & \\
\hline 17 & EastCape - Horoera & $\begin{array}{l}\sim 37^{\circ} 38^{\prime} 16.10^{\prime \prime S} \\
\sim 178^{\circ} 28^{\prime} 1.31^{\prime \prime} \mathrm{E}\end{array}$ & 4 & $\begin{array}{l}0 \mathrm{Lv} / \mathrm{W}, \\
2 \mathrm{Lv} / \mathrm{W} 2, \\
2 \mathrm{Lv} / \mathrm{W} 3\end{array}$ & 1 & $1 \mathrm{Lv} / \mathrm{W}$ \\
\hline 18 & EastCape - Hautai Beach & $\begin{array}{l}37^{\circ} 38^{\prime} 23.02 " \mathrm{~S} \\
178^{\circ} 28^{\prime} 40.22^{\prime \prime} \mathrm{E}\end{array}$ & 4 & $\begin{array}{l}0 \mathrm{Lv} / \mathrm{W} \\
4 \mathrm{Lv} / \mathrm{W} 2\end{array}$ & 2 & $2 \mathrm{Lv} / \mathrm{W}$ \\
\hline 19 & Waimarama & $\begin{array}{l}39^{\circ} 47^{\prime} 5.50 " \mathrm{~S} \\
176^{\circ} 59^{\prime} 59.30^{\prime \prime} \mathrm{E}\end{array}$ & 3 & $\begin{array}{l}0 \mathrm{Lv} / \mathrm{W} \\
3 \mathrm{Lv} / \mathrm{W} 3\end{array}$ & 1 & $1 \mathrm{Lv} / \mathrm{W}$ \\
\hline 20 & Mataikona - Pop1 & $\begin{array}{l}40^{\circ} 47^{\prime} 43.27 " \mathrm{~S} \\
176^{\circ} 15^{\prime} 56.46 " \mathrm{E}\end{array}$ & 10 & $\begin{array}{l}1 \mathrm{Lv} / \mathrm{W} \\
9 \mathrm{Lv} / \mathrm{W} 4\end{array}$ & & \\
\hline 20 & Mataikona - Pop2 & $\begin{array}{l}40^{\circ} 47^{\prime} 38.47^{\prime \prime S} \\
176^{\circ} 15^{\prime} 58.26 " \mathrm{E}\end{array}$ & 2 & $\begin{array}{l}0 \mathrm{Lv} / \mathrm{W} \\
2 \mathrm{Lv} / \mathrm{W} 4\end{array}$ & & \\
\hline 21 & Riversdale south & $\begin{array}{l}41^{\circ} 6 ' 29.73 " \mathrm{~S} \\
176^{\circ} 4^{\prime} 10.55^{\prime \prime} \mathrm{E}\end{array}$ & 9 & $\begin{array}{l}2 \mathrm{Lv} / \mathrm{W} \\
7 \mathrm{Lv} / \mathrm{W} 4\end{array}$ & 2 & $2 \mathrm{Lv} / \mathrm{W}$ \\
\hline 21 & Riversdale Beach & & 3 & $\begin{array}{l}1 \mathrm{Lv} / \mathrm{W} \\
2 \mathrm{Lv} / \mathrm{W} 4\end{array}$ & & \\
\hline 22 & Cape Palliser & $\begin{array}{l}41^{\circ} 36^{\prime} 48.47^{\prime \prime S} \\
175^{\circ} 17^{\prime} 32.66 " \mathrm{E}\end{array}$ & 3 & $3 \mathrm{Lv} / \mathrm{W}$ & 2 & $2 \mathrm{Lv} / \mathrm{W}$ \\
\hline 23 & Breakers Bay - Wgtn & $\begin{array}{l}41^{\circ} 20^{\prime} 8.17 " \mathrm{~S} \\
174^{\circ} 49^{\prime} 32.54 " \mathrm{E}\end{array}$ & 2 & $2 \mathrm{Lv} / \mathrm{W}$ & & \\
\hline 23 & Moa Point - Wgtn & $\begin{array}{l}41^{\circ} 20^{\prime} 32.00^{\prime \prime S} \\
174^{\circ} 48^{\prime} 33.00 " \mathrm{E}\end{array}$ & 8 & $8 \mathrm{Lv} / \mathrm{W}$ & & \\
\hline 23 & Princess Bay - Wgtn & $\begin{array}{l}41^{\circ} 20^{\prime} 42.36 " \mathrm{~S} \\
174^{\circ} 47^{\prime} 15.89 " \mathrm{E}\end{array}$ & 3 & $3 \mathrm{Lv} / \mathrm{W}$ & 3 & $3 \mathrm{Lv} / \mathrm{W}$ \\
\hline 23 & Island Bay - Wgtn & $\begin{array}{l}41^{\circ} 20^{\prime} 57.39^{\prime \prime S} \\
174^{\circ} 45^{\prime} 49.06^{\prime \prime} \mathrm{E}\end{array}$ & 2 & $2 \mathrm{Lv} / \mathrm{W}$ & & \\
\hline
\end{tabular}




\begin{tabular}{|c|c|c|c|c|c|c|}
\hline 24 & Makara Beach - Wgtn & $\begin{array}{l}41^{\circ} 12^{\prime} 58.11^{\prime \prime S} \\
174^{\circ} 42^{\prime} 9.89^{\prime \prime} \mathrm{E}\end{array}$ & 5 & $\begin{array}{l}4 \mathrm{Lv} / \mathrm{W}, \\
1 \mathrm{Lv} / \mathrm{W} 1\end{array}$ & 1 & $1 \mathrm{Lv} / \mathrm{W}$ \\
\hline 25 & Fighting Bay Pop1 & $\begin{array}{l}41^{\circ} 18^{\prime} 43.44^{\prime \prime S} \\
174^{\circ} 12^{\prime} 25.26^{\prime \prime} \mathrm{E}\end{array}$ & 4 & $4 \mathrm{Lv} / \mathrm{W}$ & & \\
\hline 25 & Fighting Bay Pop2 & $\begin{array}{l}41^{\circ} 18.70796 \mathrm{~S} \\
174^{\circ} 12.39924 \mathrm{E}\end{array}$ & 3 & $3 \mathrm{Lv} / \mathrm{W}$ & & \\
\hline 25 & Fighting Bay Pop3 & $\begin{array}{l}41^{\circ} 18^{\prime} 46.62^{\prime \prime S} \\
174^{\circ} 11^{\prime} 59.52 " \mathrm{E}\end{array}$ & 3 & $3 \mathrm{Lv} / \mathrm{W}$ & & \\
\hline 26 & Whites Bay & $\begin{array}{l}41^{\circ} 23^{\prime} 17.96 " \mathrm{~S} \\
174^{\circ} 323.28^{\prime \prime} \mathrm{E}\end{array}$ & 17 & $17 \mathrm{Lv} / \mathrm{W}$ & 2 & $2 \mathrm{Lv} / \mathrm{W}$ \\
\hline \multicolumn{2}{|c|}{ L. variegata $/ \mathrm{K}(55)$} & & 55 & & 5 & \\
\hline 27 & Cape Campbell & $\begin{array}{l}41^{\circ} 43^{\prime} 46.18^{\prime \prime S} \\
174^{\circ} 16^{\prime} 19.08^{\prime \prime} \mathrm{E}\end{array}$ & 7 & $\begin{array}{l}0 \mathrm{Lv} / \mathrm{K} \\
7 \mathrm{Lv} / \mathrm{K} 1\end{array}$ & 1 & $1 \mathrm{Lv} / \mathrm{K}$ \\
\hline 28 & Kekerengu & $\begin{array}{l}42^{\circ} 0^{\prime} 15.57 " \mathrm{~S} \\
174^{\circ} 00^{\prime} 43.77^{\prime \prime} \mathrm{E}\end{array}$ & 4 & $4 \mathrm{Lv} / \mathrm{K}$ & & \\
\hline 29 & Waipapa & $\begin{array}{l}42^{\circ} 12^{\prime} 39.35^{\prime \prime S} \\
173^{\circ} 52^{\prime} 20.22^{\prime \prime} \mathrm{E}\end{array}$ & 10 & $10 \mathrm{Lv} / \mathrm{K}$ & & \\
\hline 30 & New Wharf - Kaikoura & $\begin{array}{l}42^{\circ} 24^{\prime} 47.17 " \mathrm{~S} \\
173^{\circ} 42^{\prime} 8.22^{\prime \prime} \mathrm{E}\end{array}$ & 2 & $2 \mathrm{Lv} / \mathrm{K}$ & 2 & $2 L v / K$ \\
\hline 30 & Seal Colony - Kaikoura & $\begin{array}{l}42^{\circ} 25^{\prime} 30.07^{\prime \prime S} \\
173^{\circ} 43^{\prime} 1.30^{\prime \prime} \mathrm{E}\end{array}$ & 16 & $16 \mathrm{Lv} / \mathrm{K}$ & 1 & $1 \mathrm{Lv} / \mathrm{K}$ \\
\hline 30 & South Bay - Kaikoura & $\begin{array}{l}42^{\circ} 25^{\prime} 33.45^{\prime \prime S} \\
173^{\circ} 41^{\prime} 6.25^{\prime \prime} \mathrm{E}\end{array}$ & 9 & $9 \mathrm{Lv} / \mathrm{K}$ & & \\
\hline 31 & $3 \mathrm{~km}$ north of Goose Bay & $\begin{array}{l}42^{\circ} 27^{\prime} 32.52^{\prime \prime S} \\
173^{\circ} 33^{\prime} 6.88^{\prime \prime} \mathrm{E}\end{array}$ & 4 & $4 \mathrm{Lv} / \mathrm{K}$ & & \\
\hline 32 & Paia Point & $\begin{array}{l}42^{\circ} 29^{\prime} 22.43 " \mathrm{~S} \\
173^{\circ} 31^{\prime} 27.05^{\prime \prime} \mathrm{E}\end{array}$ & 3 & $3 \mathrm{Lv} / \mathrm{K}$ & 1 & $1 \mathrm{Lv} / \mathrm{K}$ \\
\hline \multicolumn{2}{|c|}{ L. variegata/S (73) } & & 73 & & 6 & \\
\hline 33 & $\begin{array}{l}\text { Banks Pen. - } \\
\text { Tumbledown Bay }\end{array}$ & $\begin{array}{l}43^{\circ} 49^{\prime} 46.26^{\prime \prime S} \\
172^{\circ} 43^{\prime} 39.78^{\prime \prime} \mathrm{E}\end{array}$ & 1 & $1 \mathrm{Lv} / \mathrm{S}$ & 1 & $1 \mathrm{Lv} / \mathrm{S}$ \\
\hline 34 & Mapoutahi - Otago & $\begin{array}{l}45^{\circ} 44^{\prime} 06.58^{\prime \prime S} \\
170^{\circ} 37^{\prime} 02.82^{\prime \prime} \mathrm{E}\end{array}$ & 12 & $12 \mathrm{Lv} / \mathrm{S}$ & & \\
\hline 34 & Tairoa Head - Otago & $\begin{array}{l}\sim 45^{\circ} 46^{\prime} 59.95^{\prime \prime S} \\
\sim 170^{\circ} 44^{\prime} 0.69^{\prime \prime} \mathrm{E}\end{array}$ & 5 & $5 \mathrm{Lv} / \mathrm{S}$ & & \\
\hline 35 & $\begin{array}{l}\text { Roaring Bay - Nugget } \\
\text { Point }\end{array}$ & $\begin{array}{l}46^{\circ} 26^{\prime} 53.53 " \mathrm{~S} \\
169^{\circ} 47^{\prime} 55.93^{\prime \prime} \mathrm{E}\end{array}$ & 4 & $\begin{array}{l}3 \mathrm{Lv} / \mathrm{S} \\
1 \mathrm{Lv} / \mathrm{S} 1\end{array}$ & 1 & $1 \mathrm{Lv} / \mathrm{S}$ \\
\hline 36 & CurioBay & $46^{\circ} 39^{\prime} 38.85^{\prime \prime S}$ & 8 & $8 \mathrm{Lv} / \mathrm{S}$ & 2 & $2 \mathrm{Lv} / \mathrm{S}$ \\
\hline
\end{tabular}




\begin{tabular}{|c|c|c|c|c|c|c|}
\hline & & $169^{\circ} 6{ }^{\prime} 29.45^{\prime \prime} \mathrm{E}$ & & & & \\
\hline 37 & Bluff & $\begin{array}{l}46^{\circ} 36^{\prime} 49.49^{\prime S} \\
168^{\circ} 21^{\prime} 27.24^{\prime \prime E}\end{array}$ & 10 & $10 \mathrm{Lv} / \mathrm{S}$ & & \\
\hline 38 & $\begin{array}{l}\text { Ackers Pt. Lighthouse - } \\
\text { Stewart Is. }\end{array}$ & $\begin{array}{l}46^{\circ} 53^{\prime} 46.94 " \mathrm{~S} \\
168^{\circ} 9^{\prime} 49.82^{\prime \prime} \mathrm{E}\end{array}$ & 10 & $10 \mathrm{Lv} / \mathrm{S}$ & & \\
\hline 39 & $\begin{array}{l}\text { Causet Cove - Doubtful } \\
\text { Sound }\end{array}$ & $\begin{array}{l}45^{\circ} 17^{\prime} 47.63 " \mathrm{~S} \\
166^{\circ} 54^{\prime} 33.01^{\prime \prime} \mathrm{E}\end{array}$ & 22 & $22 \mathrm{Lv} / \mathrm{S}$ & 1 & $1 \mathrm{Lv} / \mathrm{S}$ \\
\hline 39 & $\begin{array}{l}\text { Shelter Islands - Doubtful } \\
\text { Sound }\end{array}$ & $\begin{array}{l}45^{\circ} 16^{\prime} 13.54 " \mathrm{~S} \\
166^{\circ} 53^{\prime} 29.26^{\prime \prime} \mathrm{E}\end{array}$ & 1 & $1 \mathrm{Lv} / \mathrm{S}$ & 1 & $1 \mathrm{Lv} / \mathrm{S}$ \\
\hline \multicolumn{2}{|c|}{ L. adamsiae (18) } & & 18 & & 4 & \\
\hline 40 & South Promontory & $\begin{array}{l}48^{\circ} 0^{\prime} 54.38^{\prime \prime S} \\
\sim 166^{\circ} 34^{\prime} 40.55^{\prime \prime} \mathrm{E}\end{array}$ & 8 & $8 \mathrm{La}$ & 1 & $1 \mathrm{Lv} / \mathrm{S}$ \\
\hline 41 & Tahi & $\begin{array}{l}48^{\circ} 03^{\prime} 42.42^{\prime \prime S} \\
\sim 166^{\circ} 30^{\prime} 59.99^{\prime \prime} \mathrm{E}\end{array}$ & 10 & $10 \mathrm{La}$ & 3 & $1 \mathrm{Lv} / \mathrm{S}$ \\
\hline \multicolumn{2}{|c|}{ L. brevifolia (24) } & & 24 & & 4 & \\
\hline 42 & $\begin{array}{l}\text { Monumental Island - } \\
\text { Auckland Is. }\end{array}$ & $\begin{array}{l}50^{\circ} 50^{\prime} 2.15^{\prime \prime} \mathrm{S} \\
\sim 165^{\circ} 55^{\prime} 7.13^{\prime \prime} \mathrm{E}\end{array}$ & 1 & $1 \mathrm{Lb}$ & & \\
\hline 43 & $\begin{array}{l}\text { Smoothwater Bay - } \\
\text { Campbell Is. }\end{array}$ & $\begin{array}{l}52^{\circ} 32^{\prime} 38.87^{\prime \prime S} \\
\sim 169^{\circ} 15^{\prime} 9.09^{\prime \prime} \mathrm{E}\end{array}$ & 1 & $1 \mathrm{Lb}$ & 1 & $1 \mathrm{Lb}$ \\
\hline 43 & $\begin{array}{l}\text { Perseverance Harbour - } \\
\text { Campbell Is. }\end{array}$ & & 11 & $11 \mathrm{Lb}$ & 1 & $1 \mathrm{Lb}$ \\
\hline 44 & Antipodes Is. & $\begin{array}{l}\sim 49^{\circ} 41^{\prime} 12.94 " \mathrm{~S} \\
\sim 178^{\circ} 46^{\prime} 13.05^{\prime \prime} \mathrm{E}\end{array}$ & 4 & $4 \mathrm{Lb}$ & 1 & $1 \mathrm{Lb}$ \\
\hline 45 & Bounty Is. & & 7 & $7 \mathrm{Lb}$ & 1 & $1 \mathrm{Lb}$ \\
\hline \multicolumn{2}{|c|}{ L. tholiformis (43) } & & 43 & & 5 & \\
\hline 46 & Kaingaroa Harbour & $\begin{array}{l}43^{\circ} 43^{\prime} 46.10^{\prime \prime S} \\
176^{\circ} 16^{\prime} 11.15^{\prime \prime} \mathrm{W}\end{array}$ & 5 & $5 \mathrm{LtX}$ & & \\
\hline 47 & Wharekauri & $\begin{array}{l}\sim 43^{\circ} 42^{\prime} 15.18^{\prime \prime} \mathrm{S} \\
\sim 176^{\circ} 34^{\prime} 54.12^{\prime \prime} \mathrm{W}\end{array}$ & 10 & $\begin{array}{l}3 \mathrm{LtX}, \\
7 \mathrm{Lt} 1\end{array}$ & 1 & $1 \mathrm{Lt}$ \\
\hline 48 & $\begin{array}{l}\text { Point Dorset (1) - Port } \\
\text { Hutt }\end{array}$ & $\begin{array}{l}43^{\circ} 48^{\prime} 57.40^{\prime \prime S} \\
176^{\circ} 42^{\prime} 13.94 " \mathrm{~W}\end{array}$ & 3 & $\begin{array}{l}2 \mathrm{LtX}, \\
1 \mathrm{Lt} 1\end{array}$ & 1 & $1 \mathrm{Lt}$ \\
\hline 48 & $\begin{array}{l}\text { Point Dorset (2) - Port } \\
\text { Hutt }\end{array}$ & $\begin{array}{l}43^{\circ} 49^{\prime} 54.73^{\prime \prime S} \\
176^{\circ} 45^{\prime} 23.05^{\prime \prime} \mathrm{W}\end{array}$ & 1 & $1 \mathrm{LtX}$ & & \\
\hline 49 & Hanson Point - Waitangi & $\begin{array}{l}43^{\circ} 56^{\prime} 43.08^{\prime \prime S} \\
176^{\circ} 33^{\prime} 41.20^{\prime \prime} \mathrm{W}\end{array}$ & 5 & $\begin{array}{l}4 \mathrm{LtX}, \\
1 \mathrm{Lt} 1\end{array}$ & & \\
\hline 50 & Wharf reef - Owenga & $44^{\circ} 1 ' 25.21^{\prime \prime S}$ & 7 & $\begin{array}{l}2 \mathrm{LtX}, \\
4 \mathrm{Lt} 1\end{array}$ & 2 & $2 \mathrm{Lt}$ \\
\hline
\end{tabular}




\begin{tabular}{|c|c|c|c|c|c|c|}
\hline & & $176^{\circ} 22^{\prime} 7.87^{\prime \prime} \mathrm{W}$ & & $1 \mathrm{Lt} 2$ & & \\
\hline 50 & Te One Creek - Owenga & $\begin{array}{l}44^{\circ} 11^{\prime} 12.53 " \mathrm{~S} \\
176^{\circ} 22^{\prime} 51.60^{\prime \prime} \mathrm{W}\end{array}$ & 6 & $\begin{array}{l}2 \mathrm{LtX}, \\
3 \mathrm{Lt} 1 \\
1 \mathrm{Lt} 3\end{array}$ & & \\
\hline 50 & Manukau Point & $\begin{array}{l}44^{\circ} 11^{\prime} 58.86^{\prime \prime S} \\
176^{\circ} 19^{\prime} 47.52^{\prime \prime} \mathrm{W}\end{array}$ & 5 & $\begin{array}{l}4 \mathrm{LtX}, \\
1 \mathrm{Lt} 4\end{array}$ & & \\
\hline 51 & C. Lane & & 1 & $\begin{array}{l}0 \mathrm{LtX}, \\
1 \mathrm{Lt} 1\end{array}$ & 1 & $1 \mathrm{Lt}$ \\
\hline \multicolumn{2}{|c|}{ L. corrugata (13) } & & 13 & & 2 & \\
\hline 52 & $\begin{array}{l}\text { Skeletton Pt. - Binalong } \\
\text { Bay }\end{array}$ & $\begin{array}{l}41^{\circ} 14^{\prime} 54.93 " \mathrm{~S} \\
148^{\circ} 19^{\prime} 46.11^{\prime \prime} \mathrm{E}\end{array}$ & 2 & $\begin{array}{l}0 \mathrm{Lc} 1, \\
2 \mathrm{Lc} 3\end{array}$ & 1 & $1 L c 2$ \\
\hline 53 & Four Mile Creek & $\begin{array}{l}41^{\circ} 32^{\prime} 25.74 " \mathrm{~S} \\
148^{\circ} 17^{\prime} 9.53 " \mathrm{E}\end{array}$ & 1 & $\begin{array}{l}0 \mathrm{Lc} 1, \\
1 \mathrm{Lc} 2\end{array}$ & & \\
\hline 54 & Bicheno & $\begin{array}{l}41^{\circ} 52^{\prime} 29.77 " \mathrm{~S} \\
148^{\circ} 18^{\prime} 40.88^{\prime \prime} \mathrm{E}\end{array}$ & 2 & $\begin{array}{l}0 \mathrm{Lc} 1, \\
2 \mathrm{Lc} 2\end{array}$ & 1 & $1 \mathrm{Lc}$ \\
\hline 55 & Remarkable Cave & $\begin{array}{l}43^{\circ} 11^{\prime} 19.48^{\prime \prime S} \\
147^{\circ} 50^{\prime} 40.58^{\prime \prime} \mathrm{E}\end{array}$ & 2 & $2 \mathrm{Lc1}$ & & \\
\hline 56 & Kingston Beach - Hobart & $\begin{array}{l}\sim 42^{\circ} 59^{\prime} 4.12^{\prime \prime S} \\
\sim 147^{\circ} 19^{\prime} 34.20^{\prime \prime} \mathrm{E}\end{array}$ & 1 & $1 \mathrm{Lc} 1$ & & \\
\hline 56 & $\begin{array}{l}\text { Blackman's Beach - } \\
\text { Hobart }\end{array}$ & $\begin{array}{l}43^{\circ} 0^{\prime} 28.02 " \mathrm{~S} \\
147^{\circ} 19^{\prime} 45.57^{\prime \prime} \mathrm{E}\end{array}$ & 1 & $1 \mathrm{Lc} 1$ & & \\
\hline 57 & Ladies Bay - Southport & $\begin{array}{l}43^{\circ} 26^{\prime} 27.84 " \mathrm{~S} \\
146^{\circ} 59^{\prime} 18.64 " \mathrm{E}\end{array}$ & 4 & $\begin{array}{l}0 \mathrm{Lc} 1, \\
4 \mathrm{Lc} 4\end{array}$ & & \\
\hline
\end{tabular}


Table 3.2 Dataset characteristics; showing the number of individuals (N), the length of the marker region and number of variable sites; A) atp8-sp and B) rbc-sp. ${ }^{1}$ variable sites of the last $40 \mathrm{bp}$ of the atp8-gene; ${ }^{2}$ variable sites of the first $17 \mathrm{bp}$ of the trnS-gene.

\begin{tabular}{|c|c|c|c|c|c|c|c|c|c|}
\hline A) atp8-sp & All & L. $\operatorname{var} / \mathrm{N}$ & L. var/W & L. var $/ \mathrm{K}$ & L. var/S & L. $a d a$ & L. bre & L. cor & L. tho \\
\hline $\mathrm{N}$ & 493 & 184 & 85 & 55 & 73 & 18 & 24 & 11 & 43 \\
\hline length & $133 b p$ & $113 b p$ & $113 b p$ & $114 b p$ & $113 b p$ & $103 \mathrm{bp}$ & $113 b p$ & $103 b p$ & $119 \mathrm{bp}$ \\
\hline variable sites & 27 & 2 & 4 & 1 & 1 & - & - & 3 & 3 \\
\hline atp8-gene $^{1}$ & 5 & 3 & - & - & - & - & - & 2 & - \\
\hline $\operatorname{trnS}$-gene ${ }^{2}$ & 1 & 1 & - & - & - & - & - & - & - \\
\hline indel & 13bp; 1bp; 6bp; 18bp; 16bp & $\begin{array}{l}12 \mathrm{bp} \text { del }(\mathrm{Lv} / \mathrm{NM}) \\
13 \mathrm{bp} \text { ins }(\mathrm{Lv} / \mathrm{NS})\end{array}$ & - & - & - & - & - & - & - \\
\hline \multicolumn{10}{|l|}{ B) rbc-sp } \\
\hline $\mathrm{N}$ & 54 & 13 & 14 & 5 & 6 & 4 & 4 & 3 & 5 \\
\hline length & $363 b p$ & $363 b p$ & $363 b p$ & $363 b p$ & $363 b p$ & $363 b p$ & $363 b p$ & $357 \mathrm{bp}$ & $363 b p$ \\
\hline variable sites & 8 & 1 & - & - & - & - & - & - & - \\
\hline indel & $32 \mathrm{bp} ; 6 \mathrm{bp}$ & $32 \mathrm{bp}$ & - & - & - & - & - & - & - \\
\hline
\end{tabular}




\subsection{References}

Apte, S. \& Gardner, J. P. A. 2002. Population genetic subdivision in the New Zealand greenshell mussel (Perna canaliculus) inferred from single-strand conformation polymorphism analysis of mitochondrial DNA. Mol. Ecol. $11: 1617-28$.

Ayers, K. L. \& Waters, J. M. 2005. Marine biogeographic disjunction in central New Zealand. Mar. Biol. 147:1045-52.

Bandelt, H.-J., Forster, P. \& Röhl, A. 1999. Median-joining networks for inferring intraspecific phylogenies. Mol. Biol. Evol. 16:37-44.

Bassam, B. J., Caetano-Anolles, G. \& Gresshoff, P. M. 1991. Fast and sensitive silver staining of DNA in polyacrylamide gels. Anal. Biochem. 196:80-83.

Bonfield, J. K., Smith, K. F. \& Staden, R. 1995. A new DNA sequence assembly program. Nucleic Acids Res. 23:4992-99.

Buchanan, J. \& Zuccarello, G. C. 2010 (submitted). Phylogeography of the endemic New Zealand alga Carpophyllum maschalocarpum (Fucales, Sargassaceae) shows the influence of contemporary processes and historical events.

Bunce, M., Worthy, T. H., Phillips, M. J., Holdaway, R. N., Willerslev, E., Hailef, J., Shapirog, B., Scofield, R. P., Drummond, A., Kamp, P. J. J. \& Cooper, A. 2009. The evolutionary history of the extinct ratite moa and New Zealand Neogene paleogeography. PNAS 106:20646-51.

Carranza, S., Arnold, E. N., Mateo, J. A. \& Lopez-Jurado, L. F. 2000. Long-distance colonization and radiation in gekkonid lizards, Tarentola (Reptilia: 
Gekkonidae), revealed by mitochondrial DNA sequences. Proc. R. Soc. Biol. Sci. Ser. B 267:637-49.

Carter, L. 2001. Currents of change: the ocean folw in a changing world. Water \& Atmosphere 9:15-17.

Chiswell, S. M. 2000. The Wairarapa Coastal Current. N. Z. J. Mar. Freshw. Res. 34:303-15.

Chiswell, S. M. 2009. Colonisation and connectivity by intertidal limpets among New Zealand, Chatham and Sub-Antarctic Islands. II. Oceanographic connections. Mar. Ecol. Prog. Ser. 388:121-35.

Coleman, J. L., Shane, P. A. R., Grant-Mackie, J. A. \& Gregory, M. R. 2001. Identification of a distal ignimbrite in Quaternary strata of the Gisborne area: implications for ignimbrite dispersal, stratigraphy, and paleofauna. New Zealand Journal of Geology \& Geophysics 44:337-45.

Edding, M. E., Fonk, E. A. \& Macchiavello, J. E. 1994. Lessonia. In: Akatsuka, I. [Ed.] Biology of Economic Algae. SPB Academic Pubishing, The Hague, pp. 407-46.

Ewing, B. \& Green, P. 1998. Base-calling of automated sequencer traces using phred. II. Error probabilities. Genome Res. 8:186-94.

Excoffier, L., Laval, G. \& Schneider, S. 2005. Arlequin ver. 3.0: An integrated software package for population genetics data analysis. Evolutionary Bioinformatics Online 1:47-50. 
Faugeron, S., Martinez, E. A., Correa, J. A. \& Billot, C. 2005. Long-term copper mine waste disposal in northern Chile associated with gene flow disruption of the intertidal kelp Lessonia nigrescens. Mar. Ecol. Prog. Ser. 288:129-40.

Fleming, C. A. 1979. The Geological History of New Zealand and its Life. Auckland University Press, Auckland, New Zealand, 141 pp.

Francis, M. P. 1996. Geographic distribution of marine reef fishes in the New Zealand region. N. Z. J. Mar. Freshw. Res. 30:35-55.

Fraser, C. I., Nikula, R., Spencer, H. G. \& Waters, J. M. 2009a. Kelp genes reveal effects of Sub-Antarctic sea ice during the Last Glacial Maximum. Proc. Natl. Acad. Sci. U. S. A. 106:3249-53.

Fraser, C. I., Spencer, H. G. \& Waters, J. M. 2009b. Glacial oceanographic contrasts explain phylogeography of Australian bull kelp. Mol. Ecol. 18:2287-96.

Froggatt, P. C., Nelson, C. S., Carter, L., Griggs, G. \& Black, K. P. 1986. An exceptionally large late Quaternary eruption from New Zealand. Nature 319:578-82.

Gibbs, C. F. 1992. Oceanography of Bass Strait: Implications for the food supply of Little Penguins Eudyptula minor. Emu 91:395-401.

Goldstien, S. J., Schiel, D. R. \& Gemmell, N. J. 2006. Comparative phylogeography of coastal limpets across a marine disjunction in New Zealand. Mol. Ecol. $15: 3259-68$. 
Hall, T. A. 1999. BioEdit: a user-friendly biological sequence alignment editor and analysis program for Windows 95/98/NT. Nucl. Acids. Symp. Ser. . 7.0.9.0 ed., pp. 95-98.

Hundertmark, K. J., Bowyer, R. T., Shields, G. F. \& Schwartz, C. C. 2003. Mitochondrial phylogeography of Moose (Alces alces) in North America. J. Mammal. 84:718-28.

King, P. R. 2000. Tectonic reconstructions of New Zealand: 40 Ma to the Present. New Zealand Journal of Geology \& Geophysics 43:611-38.

Knox, G. A. 1975. The marine benthic ecology and biogeography. In: Kuschel, G. [Ed.] Biogeography and ecology in New Zealand. Dr. W. Junk, The Hague, pp. 353-403.

Lane, C. E., Mayes, C., Druehl, L. D. \& Saunders, G. W. 2006. A multi-gene molecular investigation of the kelp (Laminariales, Phaeophyceae) supports substantial taxonomic re-organization. J. Phycol. 42:493-512.

Lewis, K. B., Carter, L. \& Davey, F. J. 1994. The opening of Cook Strait: Interglacial tidal scour and aligning basins at a subduction to transform plate edge. Marine Geology 116:293-312.

Macaya, E. C. \& Zuccarello, G. C. 2010. DNA barcoding and genetic divergence in the giant kelp Macrocystis (Laminariales). J. Phycol. 46:736-42.

Manville, V. \& Wilson, C. J. N. 2004. The 26.5 ka Oruanui eruption, New Zealand: a review of the roles of volcanism and climate in the post-eruptive 
sedimentary response. New Zealand Journal of Geology \& Geophysics 47:525-47.

McLoughlin, S. 2001. The breakup history of Gondwana and its impact on preCenozoic floristic provincialism. Aust. J. Bot. 49:271-300.

Ministry of Fisheries and Department of Conservation 2008. Marine Protected Areas: Classification, Protection Standard and Implementation Guidelines. Ministry of Fisheries and Department of Conservation, Wellington, 54 pp.

Moore, L. B. 1949. The marine algal provinces of New Zealand. Transactions of the Royal Society of New Zealand. Section C-Botanical Sciences-Abstracts and Titles 77:187-89.

Moore, L. B. 1961. Distribution Patterns in New Zealand Seaweeds. Tuatara 9:1823.

MPA 2008 see Ministry of Fisheries and Department of Conservation 2008.

Neale, D. \& Nelson, W. 1998. Marine Algae of the West Coast, South Island, New Zealand. Tuhinga 10:87-118.

Nelson, W. A. 1994. Distribution of macroalgae in New Zealand: An archipelago in space and time. Bot. Mar. 37:221-33.

Newnham, R. M., Lowe, D. J. \& Alloway, B. V. 1999. Volcanic hazards in Auckland, New Zealand: a preliminary assessment of the threat posed by central North Island silicic volcanism based on the Quaternary tephrostratigraphical record. Geological Society, London, Special Publications 161:27-45. 
Polzin, T. \& Daneschmand, S. V. 2003. On Steiner trees and minimum spanning trees in hypergraphs. Operations Research Letters 31:12-20.

Powell, W. B. 1961. New Zealand biotic provinces. Tuatara 9:2-8.

Ross, P. M., Hogg, I. D., Pilditch, C. A. \& Lundquist, C. J. 2009. Phylogeography of New Zealand's coastal benthos. N. Z. J. Mar. Freshw. Res. 43:1009-27.

Schnabel, K. E., Hogg, I. D. \& Chapman, M. A. 2000. Population genetic structures of two New Zealand corophiid amphipods and the presence of morphologically cryptic species: Implications for the conservation of diversity. N. Z. J. Mar. Freshw. Res. 34:637-44.

Searles, R. B. 1978. Genus Lessonia Bory (Phaeophyta, Laminariales) in Southern Chile and Argentina. Br. Phycol. J. 13:361-81.

Shears, N. T., Smith, F., Babcock, R. C., Duffy, C. A. J. \& Villouta, E. 2008. Evaluation of biogeographic classification schemes for conservation planning: Application to New Zealand's coastal marine environment. Conserv. Biol. 22:467-81.

Sinclair, E. A., Perez-Losada, M. \& Crandall, K. A. 2005. Molecular phylogenetics for conservation biology. In: Purvis, A., Gittleman, J. L. \& Brooks, T. [Eds.] Phylogeny and Conservation. Cambridge University Press, New York, 431 pp.

Staden, R., Judge, D. P. \& Bonfield, J. K. 2002. Sequence Assembly and Finishing Methods. In: Andreas D. Baxevanis, B. F. F. O. [Ed.] Bioinformatics (Second Edition). pp. 303-22. 
Stanton, B. R., Sutton, P. J. H. \& Chiswell, S. M. 1997. The East Auckland Current, 1994-95. N. Z. J. Mar. Freshw. Res. 31:537-49.

Stevens, M. I. \& Hogg, I. D. 2004. Population genetic structure of New Zealand's endemic corophiid amphipods: evidence for allopatric speciation. Biol. J. Linn. Soc. 81:119-33.

Thiel, M. \& Haye, P. A. 2006. The ecology of rafting in the marine environment. III. Biogeographical and evolutionary consequences. Oceanography and Marine Biology: An Annual Review 44:323-429.

Thompson, J. D., Higgins, D. G. \& Gibson, T. J. 1994. CLUSTAL-W - Improving the sensitivity of progressive multiple sequence alignment through sequence weighting, position-specific gap penalties and weight matrix choice. Nucleic Acids Res., pp. 4673-80.

Verbruggen, H. \& Theriot, E. C. 2008. Building trees of algae: some advances in phylogenetic and evolutionary analysis. Eur. J. Phycol. 43:229-52.

Voisin, M., Engel, C. R. \& Viard, F. 2005. Differential shuffling of native genetic diversity across introduced regions in a brown alga: Aquaculture vs. maritime traffic effects. Proc. Natl. Acad. Sci. U. S. A. 102:5432-37.

Wallis, G. P. \& Trewick, S. A. 2009. New Zealand phylogeography: evolution on a small continent. Mol. Ecol. 18:3548-80.

Walls, K. 1995. The New Zealand experience in developing a marine biogeographic regionalisation. In: Muldoon, J. [Ed.] Towards a marine regionalisation for 
Australia: proceedings of a workshop. Great Barrier Reef Marine Park Authority, Townsville, Australia, pp. 33-48.

Waters, J. M. \& Roy, M. S. 2004a. Phylogeography of a high-dispersal New Zealand sea-star: does upwelling block gene-flow? Mol. Ecol. 13:2797-806.

Waters, J. M. \& Roy, M. S. 2004b. Out of Africa: The slow train to Australasia. Syst. Biol. 53:18-24.

Wilson, C. J. N., Houghton, B. F., Kampt, P. J. J. \& McWilliamst, M. O. 1995. An exceptionally widespread ignimbrite with implications for pyroclastic flow emplacement. Nature 378:605-07.

Zuccarello, G. C. \& Lokhorst, G. M. 2005. Molecular phylogeny of the genus Tribonema (Xanthophyceae) using rbcL gene sequence data: monophyly of morphologically simple algal species. Phycologia 44:384-92.

Zuccarello, G. C., West, J. A., Kamiya, M. \& King, R. J. 1999. A rapid method to score plastid haplotypes in red seaweeds and its use in determining parental inheritance of plastids in the red alga Bostrychia (Ceramiales). Hydrobiologia 401:207-14. 



\section{Chapter 4}

\section{Characterisation of microsatellites}

in the Southern Hemisphere kelp Lessonia variegata (Phaeophyceae, Laminariales)

\subsection{Abstract}

Lessonia variegata has recently been split into four species with a localized, nonoverlapping distribution. One lineage, L. variegata Wellington lineage, is found on both the North Island and South Island of New Zealand. In order to investigate connectivity and population differentiation I developed ten microsatellite loci, which were tested on 150 samples from three populations. Seven markers were polymorphic, displaying 2-24 alleles per locus; one polymorphic marker was however, difficult to score and requires further optimisation. All eight tested markers were able to amplify across the four members of the L. variegata species complex, and differences in length were noted. 


\subsection{Introduction}

Large brown algae of the order Laminariales (kelp) play an important role in cold temperate regions (Billot et al. 1998) where they form unique habitats and ecological niches for a variety of organisms (Edding et al. 1994, Schwarz et al. 2006). Lessonia variegata J. Agardh, which is found at exposed rocky coasts on the three main islands of New Zealand, has recently been split into four cryptic species (Chapter 2). The Wellington lineage (L. variegata/W) is distributed from the most eastern point of the North Island of New Zealand southward along the east coast, across Cook Strait, to the northern tip of the South Island (Chapter 3). To further investigate population structure and connectivity between populations, highly variable molecular markers are needed. In general, microsatellites are several orders of magnitude faster evolving than other DNA sequences (Gilbert et al. 1990). Therefore microsatellites are a powerful tool for detecting recent evolutionary changes within and between populations. Few microsatellites have been developed in Laminariales (Billot et al. 1998, Whitmer 2002, Kusumo et al. 2004, Daguin et al. 2005, Li et al. 2008, Faugeron et al. 2009, Collens 2009, Dolman \& Coleman 2009, Liu et al. 2010). These have been used in parental analyses (Asensi et al. 2001, Shan \& Pang 2009) but mostly for population structure and spatial analysis where huge differences in population structure and connectivity became obvious between non-floating (Billot et al. 2003, Kusumo et al. 2006, Coleman et al. 2009) and floating Laminariales (Macaya 2010 (Thesis) pp. 90-124). However, as microsatellites normally occur in noncoding regions where mutation rates are higher, they almost always have to be species specific (Wan et al. 2004, Martinez et al. 2005). Here I 
describe the isolation and characterisation of species specific microsatellites for $L$. variegata/W. Cross-amplification to other L. variegata lineages was also tested.

\subsection{Material and Methods}

A microsatellite library for L. variegata was prepared following a modified protocol after Gardner et al. (1999). Briefly, after DNA extraction (following a modified CTAB protocol in Zuccarello \& Lokhorst 2005), approximately 30 $\mu$ g of DNA was digested with Sau3A restriction enzyme (New England BioLabs, Ipswich, MA, USA). The Sau3A cut DNA was ligated to previously phosphorylated adapters. Adapter ligated DNA was precipitated and size fractioned in $1 \%$ agarose gel to select fragments between 200 and 1000bp in length. Bands were purified from the agarose gel using QIAquick Gel Extraction Kit (Qiagen, Hilden, Germany). The DNA was hybridised in a reaction containing 200pmoles of each of three 5'biotin-labelled oligonucleotides $\left[(\mathrm{AT})_{12},(\mathrm{CA})_{12}\right.$, and $\left.(\mathrm{AAAT})_{6}\right]$. In order to limit the formation of concatemers, terminal priming sites were blocked by the addition of S61 primers (Gardner et al. 1999) to the reaction mix. Enrichment was performed while selectively capturing hybridised microsatellite repeats that bound to streptividin magnetic beads (Promega, Madison, WI, USA). Enriched DNA was purified using High Pure PCR Product Purification Kit (Roche Applied Science, Mannheim, Germany). The purified DNA was PCR amplified (using S61 primers), cleaned with Ultraclean PCR clean-up (MoBio Laboratories, Inc., Carlsbad, CA), and ligated into pGEM-T Easy Vectors (Promega) for transformation into high-efficiency competent cells (Promega). Recombinant clones were detected using blue/white screening of colonies (Sambrook et al. 1989). The first 248 white colonies were selected for PCR amplification using non-biotin-labelled $\mathrm{CA}_{12}, \mathrm{AT}_{12}, \mathrm{AAAT}_{6}$ and the forward and 
reverse M13 primers in one reaction. Colonies tested positive for microsatellites (96 of the 248 tested colonies showed two or more bands with at least one band $>236 \mathrm{bp}$ ) were again PCR amplified with only M13 primers for sequencing. Sequences showing microsatellite motifs and sufficient flanking regions were selected and primer pairs were designed with PRIMER3 (Rozen \& Skaletsky 2000).

Primers were constructed for 10 loci and dye-labelled (Table 4.1). Loci were tested for amplification in individuals from all four L. variegata lineages and variability was tested for L. variegata/W using 10 to 50 samples per locus from each of three populations that were sampled at the south-eastern part of the species range (Table 4.2).

PCR amplification was performed on a Biometra TGradient PCR machine in $15 \mu 1$ volumes containing 1x PCR buffer (New England BioLabs), 250 $\mu \mathrm{M}$ dNTPs, $2.5 \mathrm{mM} \mathrm{MgCl} 2,0.84 \% \mathrm{BSA}, 5 \mathrm{pmol}$ of each primer, $0.5 \mathrm{U}$ Taq polymerase (New England BioLabs) and $1 \mu 1$ of template DNA. PCR conditions are as indicated in Table 4.1 and involve an initial denaturation step at $94^{\circ} \mathrm{C}$ for $5 \mathrm{~min}$ (or $10 \mathrm{~min}$ for 33D) followed by cycles of denature at $94^{\circ} \mathrm{C}$, annealing at a designated temperature (Table 4.1), extension at $72^{\circ} \mathrm{C}$, and a final extension time of $10 \mathrm{~min}$ at $72^{\circ} \mathrm{C}$. The ramping speed used was $1{ }^{\circ} \mathrm{C} \mathrm{sec}$. Loci were pooled for genotyping on an ABI 3730 Genetic Analyser with GS 500 LIZ size standard. The results have been scored with PEAK SCANNER version 1.0 (https://products.appliedbiosystems.com/ab/en/US/adirect/ab?cmd=catNavigate2\&ca tID=603624), binned using MSAT-ALLELE ver. 1.01 (Alberto 2009) and double checked with MICRO-CHECKER ver. 2.2.3 (Van Oosterhout et al. 2004) for scoring errors and null alleles. ARLEQUIN ver. 3.5 (Excoffier et al. 2005) was used 
to calculate deviations from Hardy-Weinberg equilibrium (HWE), and linkage disequilibrium, as well as the amount of observed $\left(\mathrm{H}_{\mathrm{O}}\right)$ and expected heterozygosities $\left(\mathrm{H}_{\mathrm{E}}\right)$ (Table 4.2). Test probabilities were corrected according to Bonferroni procedures (Rice 1989).

\subsection{Results and Discussion}

All primers constructed for the ten loci amplified in Lessonia variegata/W (Table 4.2). However scoring was impossible for locus $14 \mathrm{D}$, showing multiple peaks as a result of stuttering and/or multiple copies of the target sequence. Optimisation of this locus is essential before further use. Two loci were monomorphic in L. variegata/W (19A and 26D) but are included here as they might be polymorphic in other $L$. variegata lineages (as it is shown for 26D, Table 4.3). Another two loci (20A and 28C) showed only minor variation and were monomorphic in some populations. The remaining five loci were polymorphic in all populations with 3 to 24 alleles per locus (Table 4.2).

No significant deviation from HWE was found except for the locus 57B within the Cape Palliser population. If significant deviations from HWE result from local inbreeding or admixture then deviations should be found at all loci. As in this population only one marker (57B) departed significantly from HWE this might indicate the presence of null alleles rather than the result of local breeding structure or admixture (Van Oosterhout et al. 2006). Linkage disequilibrium was also only significant in the Cape Palliser population between 57B and 09B. This, however, disappeared when 57B was corrected for null alleles (using Brookfield 1 method (Brookfield 1996) implemented in MICRO-CHECKER) and linkage disequilibrium 
was not evident in any other of the three populations or in any other combination of loci.

Eight loci were successfully tested for amplification in the other three lineages of the $L$. variegata species complex, showing variation within and between lineages (Table 4.3). 


\subsection{Tables}

Table 4.1 Primer sequences, and characteristics of ten microsatellite loci from L. variegata/W. The values for the PCR profiles are the times in seconds, spent denaturing at $94^{\circ} \mathrm{C} /$ annealing at a designated temperature/extension at $72^{\circ} \mathrm{C}$. Each PCR profile started with an initial denaturation step of $5 \mathrm{~min}(10 \mathrm{~min}$ for $33 \mathrm{D})$ at $94{ }^{\circ} \mathrm{C}$ and ended with an extension period of $10 \mathrm{~min}$ at $72^{\circ} \mathrm{C}$. One of each paired primers was dyed with FAM, VIC, PET, HEX, or NED for genotyping.

\begin{tabular}{|c|c|c|c|c|}
\hline Locus & Repeat motif & Repeat unit & Primer sequence $\left(5^{\prime}-3^{\prime}\right)$ & PCR profile \\
\hline $02 \mathrm{~A}$ & $(\mathrm{GTA})_{7}$ & 3 & FAM-GTGGTGGTCGCATTAGGAGT & $30 / 30 / 45$ at $48^{\circ} \mathrm{C}$ \\
\hline 09B & $(\mathrm{T})_{13}$ & 1 & $\begin{array}{l}\text { TCACGAGCAGTCAAGATTCG } \\
\text { VIC-CACCTGTAGCTTTTCGCTCAAACG }\end{array}$ & $\begin{array}{l}\text { for } 32 \text { cycles } \\
30 / 30 / 45 \text { at } 55^{\circ} \mathrm{C}\end{array}$ \\
\hline $14 \mathrm{D}$ & $(\mathrm{TGT})_{13}$ & 3 & $\begin{array}{l}\text { GGGAGAGAGAAAGAAGGACGAGGAT } \\
\text { VIC-CCTAACGCTGTGCAGTTGAA }\end{array}$ & $\begin{array}{l}\text { for } 32 \text { cycles } \\
30 / 30 / 45 \text { at } 55^{\circ} \mathrm{C}\end{array}$ \\
\hline $19 \mathrm{~A}$ & $(\mathrm{ATC})_{3} \mathrm{ACC}(\mathrm{ATC})_{5}$ & 3 & $\begin{array}{l}\text { AGAGAGGACGGCCCGATG } \\
\text { PET-CAATCAGCATGGTCACCACCAA }\end{array}$ & $\begin{array}{l}\text { for } 32 \text { cycles } \\
30 / 30 / 45 \text { at } 55^{\circ} \mathrm{C}\end{array}$ \\
\hline $20 \mathrm{~A}$ & $(\mathrm{TTG})_{3}(\mathrm{TTA})_{2}(\mathrm{TTG})_{3} \mathrm{CTG}(\mathrm{TTG})_{2} \mathrm{TCG}, \mathrm{TAG}$ & 3 & $\begin{array}{l}\text { CAGGATGAGTATGGTCGTGGGAAT } \\
\text { PET-TGACAGTACGCAGTACGTGTAGGT }\end{array}$ & $\begin{array}{l}\text { for } 32 \text { cycles } \\
30 / 30 / 45 \text { at } 55^{\circ} \mathrm{C}\end{array}$ \\
\hline $25 \mathrm{C}$ & $\begin{array}{l}(\text { TTGTAG })_{2} \text { TTG }(\text { TTGTAG })_{2}(\text { TTG })_{4} \\
(\text { TCA })_{8} \mathrm{~N}_{30}(\text { ACC })_{5} \mathrm{~N}_{6}(\text { ATC })_{17}\end{array}$ & 3 & $\begin{array}{l}\text { CGCTGCCACATACATGTCCTGTTA } \\
\text { FAM-CATCGTCGATAACAGCATCA }\end{array}$ & $\begin{array}{l}\text { for } 32 \text { cycles } \\
30 / 30 / 45 \text { at } 55^{\circ} \mathrm{C}\end{array}$ \\
\hline $26 \mathrm{D}$ & $\begin{array}{l}\text { TGTGGGG,TGTGGGA,(TGTGGGG })_{4} \\
\mathrm{~N}_{15}(\mathrm{GCT})_{3} \mathrm{GCC}(\mathrm{GCT})_{5}\end{array}$ & $7 \& 3$ & $\begin{array}{l}\text { TACGCCGTATGTCTGTGTGC } \\
\text { FAM-GCCGAACATCAGTATGTGTGA } \\
\text { CGGATGGACTGTCTGTGAAA }\end{array}$ & $\begin{array}{l}\text { for } 32 \text { cycles } \\
30 / 30 / 45 \text { at } 55^{\circ} \mathrm{C} \\
\text { for } 32 \text { cycles }\end{array}$ \\
\hline
\end{tabular}




\begin{tabular}{|c|c|c|c|c|}
\hline Locus & Repeat motif & Repeat unit & Primer sequence $\left(5^{\prime}-3^{\prime}\right)$ & PCR profile \\
\hline $28 \mathrm{C}$ & GGTTT,(GGGTT,AGGTT) ${ }_{3}$, GGGTT, & 5 & HEX-GCACTTAGACAGTTGGGGTGT & $30 / 30 / 45$ at $55^{\circ} \mathrm{C}$ \\
\hline $33 \mathrm{D}$ & $\begin{array}{l}(\text { GGGTT,AGGTT }),(\text { GGGTT })_{2}, \text { GTGTT } \\
(\text { GTT })_{90}\end{array}$ & 3 & $\begin{array}{l}\text { TTTGTGCTCGAAGACACCAT } \\
\text { NED-GATTTCACTCACTGGCCAAC }\end{array}$ & $\begin{array}{l}\text { for } 32 \text { cycles } \\
2 / 2 / 8 \text { at } 50^{\circ} \mathrm{C}\end{array}$ \\
\hline $57 \mathrm{~B}$ & $(\mathrm{AAC})_{22} \mathrm{AGC}(\mathrm{AAC})_{5} \mathrm{~N}_{75}$ & 3 & $\begin{array}{l}\text { ACGTGAGAACGGCAGCAG } \\
\text { PET-TCGCATCAACAACAAAATC }\end{array}$ & $\begin{array}{l}\text { for } 35 \text { cycles } \\
30 / 30 / 45 \text { at } 48^{\circ} \mathrm{C}\end{array}$ \\
\hline & $(\mathrm{AAC})_{10} \mathrm{AGC}, \mathrm{AAC}, \mathrm{AGC},(\mathrm{AAC})_{2}$ & & АСТСТTТАССССТААСССА & for 32 cycles \\
\hline
\end{tabular}


Table 4.2 Number and size range of alleles per locus combined over three populations $\left(\mathrm{N}_{\mathrm{A} / \mathrm{L}}\right)$, populations, sample size $(\mathrm{N})$, number of alleles per population $\left(\mathrm{N}_{\mathrm{A}}\right)$, observed $\left(\mathrm{H}_{\mathrm{O}}\right)$ and expected $\left(\mathrm{H}_{\mathrm{E}}\right)$ heterozygosity. * significant deviation from HWE at $\alpha=0.05 ; \mathrm{nv}=$ not variable; N/A marker needs optimisation.

\begin{tabular}{|c|c|c|c|c|c|c|c|}
\hline Locus & $\mathrm{N}_{\mathrm{A} / \mathrm{L}}$ & Size range (bp) & Population & $\mathrm{N}$ & $\mathrm{N}_{\mathrm{A}}$ & $\mathrm{H}_{\mathrm{O}}$ & $\mathrm{H}_{\mathrm{E}}$ \\
\hline \multirow[t]{2}{*}{$33 \mathrm{D}$} & 24 & $349-481$ & Moa Point & 47 & 11 & 0.809 & 0.794 \\
\hline & & & Turakirae Head & 49 & 10 & 0.735 & 0.790 \\
\hline \multirow{4}{*}{ 57B } & & & Cape Palliser & 48 & 16 & 0.813 & 0.749 \\
\hline & 10 & $293-317$ & Moa Point & 50 & 7 & 0.520 & 0.492 \\
\hline & & & Turakirae Head & 50 & 8 & 0.580 & 0.612 \\
\hline & & & Cape Palliser & 50 & 8 & $0.600 *$ & 0.714 \\
\hline \multirow[t]{2}{*}{$25 \mathrm{C}$} & 7 & $331-358$ & Moa Point & 50 & 4 & 0.220 & 0.236 \\
\hline & & & Turakirae Head & 49 & 4 & 0.286 & 0.306 \\
\hline \multirow{4}{*}{$02 \mathrm{~A}$} & & & Cape Palliser & 50 & 5 & 0.720 & 0.701 \\
\hline & 5 & $217-241$ & Moa Point & 50 & 2 & 0.020 & 0.020 \\
\hline & & & Turakirae Head & 50 & 3 & 0.120 & 0.115 \\
\hline & & & Cape Palliser & 50 & 3 & 0.140 & 0.133 \\
\hline \multirow[t]{3}{*}{ 09B } & 3 & $224-231$ & Moa Point & 50 & 2 & 0.440 & 0.465 \\
\hline & & & Turakirae Head & 50 & 2 & 0.360 & 0.453 \\
\hline & & & Cape Palliser & 50 & 3 & 0.240 & 0.251 \\
\hline \multirow[t]{3}{*}{$20 \mathrm{~A}$} & 2 & $228-237$ & Moa Point & 10 & 1 & $\mathrm{nv}$ & nv \\
\hline & & & Turakirae Head & 10 & 1 & $\mathrm{nv}$ & nv \\
\hline & & & Cape Palliser & 10 & 2 & 0.200 & 0.189 \\
\hline \multirow[t]{3}{*}{$28 \mathrm{C}$} & 2 & $166-181$ & Moa Point & 10 & 2 & 0.200 & 0.189 \\
\hline & & & Turakirae Head & 10 & 1 & $\mathrm{nv}$ & nv \\
\hline & & & Cape Palliser & 10 & 1 & $\mathrm{nv}$ & nv \\
\hline \multirow[t]{3}{*}{$19 \mathrm{~A}$} & 1 & 224 & Moa Point & 10 & 1 & $\mathrm{nv}$ & nv \\
\hline & & & Turakirae Head & 10 & 1 & nv & nv \\
\hline & & & Cape Palliser & 10 & 1 & $\mathrm{nv}$ & nv \\
\hline \multirow[t]{3}{*}{$26 \mathrm{D}$} & 1 & 158 & Moa Point & 10 & 1 & $\mathrm{nv}$ & nv \\
\hline & & & Turakirae Head & 10 & 1 & $\mathrm{nv}$ & nv \\
\hline & & & Cape Palliser & 10 & 1 & nv & nv \\
\hline 14D & N/A & N/A & needs optimisation & - & N/A & N/A & N/A \\
\hline
\end{tabular}


Table 4.3 Amplification success and allele region for three additional Lessonia variegata lineages (sample size one) in comparison with L. variegata/W (sample size as in Table 4.2). Lineage abbreviations as in Chapter 2, K Kaikoura lineage, N northern lineage, S southern lineage, W Wellington lineage.

$\begin{array}{llllll}\text { Locus } & \text { Lessonia sp. } & \text { Size range }(\mathrm{bp}) & \text { Locus } & \text { Lessonia sp. } & \text { Size range (bp) } \\ \text { 57B } & \text { L. variegata/W } & \mathbf{2 9 3 - 3 1 7} & \text { 19A } & \text { L. variegata/W } & \mathbf{2 2 4} \\ & \text { L. variegata/N } & 330 & & \text { L. variegata/N } & 224 \\ & \text { L. variegata/K } & 330 & & \text { L. variegata/K } & 224 \\ & \text { L. variegata/S } & 232-238 & & \text { L. variegata/S } & 221 \\ \text { 25C } & \text { L. variegata/W } & \mathbf{3 3 1 - 3 5 8} & \text { 20A } & \text { L. variegata/W } & \mathbf{2 2 8 - 2 3 7} \\ & \text { L. variegata/N } & 375 & & \text { L. variegata/N } & 240-243 \\ & \text { L. variegata/K } & 391 & & \text { L. variegata/K } & 240 \\ & \text { L. variegata/S } & 355-372 & & \text { L. variegata/S } & 239 \\ \text { 02A } & \text { L. variegata/W } & \mathbf{2 1 7 - 2 4 1} & \text { 28C } & \text { L. variegata/W } & \mathbf{1 6 6 - 1 8 1} \\ & \text { L. variegata/N } & 254-257 & & \text { L. variegata/N } & 196 \\ & \text { L. variegata/K } & 237 & & \text { L. variegata/K } & 170 \\ & \text { L. variegata/S } & 248 & & \text { L. variegata/S } & 170 \\ \text { 09B } & \text { L. variegata/W } & \mathbf{2 2 4 - 2 3 1} & \text { 26D } & \text { L. variegata/W } & \mathbf{1 5 8} \\ & \text { L. variegata/N } & 235 & & \text { L. variegata/N } & 158 \\ & \text { L. variegata/K } & 223 & & \text { L. variegata/K } & 149-164 \\ \text { L. variegata/S } & 225 & & \text { L. variegata/S } & 150-167\end{array}$




\subsection{References}

Alberto, F. 2009. MsatAllele_1.0: An R Package to Visualize the Binning of Microsatellite Alleles. J. Hered. 100:394-97.

Asensi, A., Gall, E. A., Marie, D., Billot, C., Dion, P. \& Kloareg, B. 2001. Clonal propagation of Laminaria digitata (Phaeophyceae) sporophytes through a diploid cell-filament suspension. J. Phycol. 37:411-17.

Billot, C., Engel, C. R., Rousvoal, S., Kloareg, B. \& Valero, M. 2003. Current patterns, habitat discontinuities and population genetic structure: the case of the kelp Laminaria digitata in the English Channel. Mar. Ecol. Prog. Ser. 253:111-21.

Billot, C., Rousvoal, S., Estoup, A., Epplen, J. T., Saumitou-Laprade, P., Valero, M. \& Kloareg, B. 1998. Isolation and characterization of microsatellite markers in the nuclear genome of the brown alga Laminaria digitata (Phaeophyceae). Mol. Ecol. 7:1778-80.

Brookfield, J. F. Y. 1996. A simple new method for estimating null allele frequency from heterozygote deficiency. Mol. Ecol. 5:453-55.

Coleman, M. A., Gillanders, B. M. \& Connell, S. D. 2009. Dispersal and gene flow in the habitat-forming kelp, Ecklonia radiata: relative degrees of isolation across an east-west coastline. Mar. Freshw. Res. 60:802-09.

Collens, J. D. 2009. Isolation and description of eight polymorphic microsatellite loci for the winged-kelp Alaria nana. Molecular Ecology Resources 9:142123. 
Daguin, C., Voisin, M., Engel, C. \& Viard, F. 2005. Microsatellites isolation and polymorphism in introduced populations of the cultivated seaweed Undaria pinnatifida (Phaeophyceae, Laminariales). Conserv. Genet. 6:647-50.

Dolman, G. \& Coleman, M. A. 2009. Characterisation of microsatellite loci in the habitat-forming kelp, Ecklonia radiata (Phaeophyceae, Laminariales). Conserv. Genet. 10:657-60.

Edding, M. E., Fonk, E. A. \& Macchiavello, J. E. 1994. Lessonia. In: Akatsuka, I. [Ed.] Biology of Economic Algae. SPB Academic Pubishing, The Hague, pp. 407-46.

Excoffier, L., Laval, G. \& Schneider, S. 2005. Arlequin ver. 3.0: An integrated software package for population genetics data analysis. Evolutionary Bioinformatics Online 1:47-50.

Faugeron, S., Veliz, D., Peralta, G., Tapia, J., Tellier, F., Billot, C. \& Martinez, E. 2009. Development and characterization of nine polymorphic microsatellite markers in the Chilean kelp Lessonia nigrescens. Molecular Ecology Resources 9:937-39.

Gardner, M. G., Cooper, S. J. B., Bull, C. M. \& Grant, W. N. 1999. Isolation of microsatellite loci from a social lizard, Egernia stokesii, using a modified enrichment procedure. J. Hered. 90:301-04.

Gilbert, D. A., Lehman, N., Obrien, S. J. \& Wayne, R. K. 1990. Genetic fingerprinting reflects population differentiation in the California ChannelIsland fox. Nature 344:764-67. 
Kusumo, H. T., Pfister, C. A. \& Wootton, J. T. 2004. Dominant (AFLP) and codominant (microsatellite) markers for the kelp Postelsia palmaeformis (Laminariales). Mol. Ecol. Notes 4:372-75.

Kusumo, H. T., Pfister, C. A. \& Wootton, J. T. 2006. Small-scale genetic structure in the sea palm Postelsia palmaeformis Ruprecht (Phaeophyceae). Mar. Biol. 149:731-42.

Li, B. J., Shi, Y. Y., Yang, G. P., Che, S., Li, X. J. \& Cong, Y. Z. 2008.

Microsatellite DNA variation of the gametophyte clones isolated from introduced Laminaria japonica (Phaeophyta) and L. longissima of china and varieties derived from them. J. Integr. Plant Biol. 50:352-59.

Liu, F. L., Wang, X. L., Yao, J. T., Fu, W. D. \& Duan, D. L. 2010. Development of expressed sequence tag-derived microsatellite markers for Saccharina (Laminaria) japonica. J. Appl. Phycol. 22:109-11.

Macaya, E. C. 2010. Phylogeny, connectivity and dispersal patterns of the giant kelp Macrocystis (Phaeophyceae). PhD Thesis, Victoria University of Wellington. $153 \mathrm{pp}$.

Martinez, E. A., Cardenas, L., Figueroa, C., Vidal, R. U. \& Billot, C. 2005. Microsatellites of Laminaria digitata tested in Lessonia nigrescens: evaluation and improvement of cross amplification between kelps of two different families. J. Appl. Phycol. 17:245-53.

Rice, W. R. 1989. Analyzing tables of statistical tests. Evolution 43:223-25. 
Rozen, S. \& Skaletsky, H. 2000. Primer3 on the WWW for general users and for biologist programmers. Methods Mol. Biol. 132:365-86.

Sambrook, J., Fritsch, E. F. \& Maniatis, T. 1989. Molecular cloning: A laboratory manual. Cold Spring Harbor Laboratory Press, New York.

Schwarz, A.-M., Hawes, I., Nelson, W. \& Andrew, N. 2006. Growth and reproductive phenology of the kelp Lessonia variegata in central New Zealand. N. Z. J. Mar. Freshw. Res. 40:273-84.

Shan, T. \& Pang, S. 2009. Assessing genetic identity of sporophytic offspring of the brown alga Undaria pinnatifida derived from mono-crossing of gametophyte clones by use of amplified fragment length polymorphism and microsatellite markers. Phycol. Res. 57:36-44.

Shan, T. F. \& Pang, S. J. 2010. Sex-linked microsatellite marker detected in the female gametophytes of Undaria pinnatifida (Phaeophyta). Phycol. Res. 58:171-76.

Van Oosterhout, C., Hutchinson, W. F., Wills, D. P. M. \& Shipley, P. 2004. MICRO-CHECKER: software for identifying and correcting genotyping errors in microsatellite data. Mol. Ecol. Notes 4:535-38.

Van Oosterhout, C., Weetman, D. \& Hutchinson, W. F. 2006. Estimation and adjustment of microsatellite null alleles in nonequilibrium populations. Mol. Ecol. Notes 6:255-56.

Wan, Q. H., Wu, H., Fujihara, T. \& Fang, S. G. 2004. Which genetic marker for, which conservation genetics issue? Electrophoresis 25:2165-76. 
Whitmer, A. C. 2002. Microsatellite markers for the intertidal kelp Postelsia palmaeformis (Heterokontophyta; Laminariales). Mol. Ecol. Notes 2:469-71.

Zuccarello, G. C. \& Lokhorst, G. M. 2005. Molecular phylogeny of the genus Tribonema (Xanthophyceae) using rbcL gene sequence data: monophyly of morphologically simple algal species. Phycologia 44:384-92. 



\section{Chapter 5}

\section{Connectivity between populations}

of Lessonia variegata

\section{(Phaeophyceae, Laminariales) across Cook Strait, New Zealand}

\subsection{Abstract}

Cook Strait is a waterway geographically separating the North Island and the South Island of New Zealand. However, in many phylogeographic and biogeographic surveys genetic breaks of North Island lineages are found south of Cook Strait implying that the breaks are not generated by the strait. In this chapter I want to evaluate the influence that Cook Strait has on population connectivity and the reason why this geographic feature does not correlate with genetic breaks. I used the recently discovered Wellington lineage of the Lessonia variegata species complex as model system. Six populations have been sampled according to a sample design that allowed me to compare genetic variation on both sides of Cook Strait to genetic variation found within and between populations along a continuous coastline. Genetic variation of five recently constructed, species specific microsatellite markers were detected and evaluated with three different methods, structure analysis, principle component analysis and F-statistics. The results indicate that genetic differentiation found between populations separated by Cook Strait was weak and no differences have been found between three connected populations at the south coast of Wellington over a distance of $32 \mathrm{~km}$. A strong break was detected between two populations separated by Palliser Bay, where unsuitable coastline created a gap 
similar to Cook Strait in width. The differences in the strength of the genetic break between the two gaps suggested that the stronger currents within Cook Strait might be responsible for enhanced connectivity. By critically evaluating the potential of possible dispersal mechanisms I concluded that rafting might be important as a means to connect populations across Cook Strait.

Abbreviations: K, number of clusters; $\mathrm{K}^{*}$, real number of clusters within a dataset; $\mathrm{L}(\mathrm{K})$, posterior probability of $\mathrm{K}$; $\mathrm{L}^{\prime}(\mathrm{K})$ and $\mathrm{L}$ '(K), first and second transformation of $\mathrm{L}(\mathrm{K})$ after Evanno et al. (2005); $\Delta \mathrm{K}$, third transformation of $\mathrm{L}(\mathrm{K})$ modified after Evanno et al. (2005); CSC, Cook Strait Cluster; WC, Wairarapa Cluster; GWG, Greater Wellington Group; Fight or [Fi], Fighting Bay; Tera or [Te], Cape Terawhiti; Moa or [Mo], Moa Point; Tura or [Tu], Turakirae Head; Mata or [Ma], Mataikona; PCA, principle component analysis; $\mathrm{R}_{\mathrm{ST}}$, a measure of population divergence that assumes a stepwise mutation model of microsatellite evolution; $\mathrm{F}_{\mathrm{GT}}$, variation among different groupings of locations; $F_{L G}$, variation among locations within groups or clusters; $\mathrm{F}_{\mathrm{IS}}$, inbreeding coefficient that measures the amount of heterozygosity in subpopulations. 


\subsection{Introduction}

To classify the coastal marine environments of New Zealand, phylogeographic (Apte \& Gardner 2002, Ayers \& Waters 2005, Goldstien et al. 2006) and/or biogeographic (Moore 1949, Knox 1975, Nelson 1994, Walls 1995, Francis 1996, Walls 2006, Shears et al. 2008, Ministry of Fisheries \& Department of Conservation 2008; hereafter called MPA 2008) approaches have been used. In these surveys common genetic breaks have been found (reviewed in Ross et al. 2009), e.g., a north-south differentiation centred on Cook Strait (Moore 1949, Francis 1996, Apte \& Gardner 2002, Star et al. 2003, Waters \& Roy 2004, Ayers \& Waters 2005, Goldstien et al. 2006, Shears et al. 2008, MPA 2008). Cook Strait separates the North and South Islands of New Zealand (Lewis et al. 1994) by at least $22 \mathrm{~km}$, and is known to be turbulent with sometimes strong tidal currents (Bowman et al. 1983). Most surveys, however, suggested the exact location of the break south of Cook Strait but not directly in congruence with the strait. A break south of Cook Strait was also found in the Lessonia variegata species complex (Chapter 3). In this chapter I want to evaluate the influence of this waterway on the connectivity of Lessonia variegata populations in comparison to populations on a continuous coastline.

The distribution and connectivity of populations in the marine realm is likely linked to the species dispersal ability (Ross et al. 2009). Natural dispersal in brown algae (kelp) of the order Laminariales is possible in several ways that enable kelp to disperse over a variety of spatial scales. The two most studied dispersal mechanisms are dispersal of zoospores and sporophytes. Zoospores tend to disperse over short distances (tens of meters (Dayton 1973, Reed et al. 1988, Norton 1992, Kusumo et al. 2006)), but have been recorded to travel up to $3.5 \mathrm{~km}$ (Reed et al. 2004). 
However, successful recruitment in Laminariales was mostly found to take place in the vicinity of the parent (<10m) (Santelices 1990, Norton 1992, Forrest et al. 2000, Faugeron et al. 2005, Kusumo et al. 2006) possibly based on the complex life cycle of the Laminariales with microscopic dioecious gametophytes. As an adaptation to exposed environments where some kelps, including Lessonia, are found, the dispersal distance might be even more limited as quick settlement enables zoospores to remain within this habitat (Taylor \& Schiel 2003). Long distance dispersal is considered to be mainly due to detached drifting sporophytes (Coyer et al. 2004, Thiel \& Gutow 2005a, Macaya et al. 2005, Macaya \& Zuccarello 2010). Some Laminariales (e.g., Macrocystis pyrifera) are positively buoyant due to gas-filled bladders called pneumatocysts, which enables detached algae to float and disperse by currents (Macaya et al. 2005, Macaya \& Zuccarello 2010). Whereas all Laminariales have dispersive zoospores, long distance dispersal via floating is confined to the few species with gas filled structures. Lessonia does not float and sinks to the sea floor if detached (Martinez et al. 2003), which would indicate poor dispersal abilities and therefore poor connectivity between populations. Martinez et al. (2003), who surveyed the recovery of Lessonia nigrescens on a disturbed coastline, calculated an average advance of populations of less than $3 \mathrm{~km}$ per year, and Faugeron et al. (2005) showed that Lessonia nigrescens had its highest genetic variation concentrated within plots of quadrants that are $20 \mathrm{~m}$ apart, suggesting restricted dispersal. However, kelp gametophytes (Lane \& Saunders 2005) and sporophytes (Fig. 1.10) have been found attached to other algae with the ability to float or raft, thus population connectivity is possible even for non-floating algae by this means (Thiel \& Gutow 2005b). Dispersal of fertile fronds or detached individuals, even if they do not have the ability to float, has been reported for some Laminariales (Dayton 1973, 
Forrest et al. 2000, Sliwa et al. 2006), including Lessonia (Marsden 1991a, Thiel \& Gutow 2005a), and might be underestimated as a means of dispersal (Faugeron et al. 2005).

Lessonia variegata J.Agardh was divided into four genetic species with distinct distribution ranges based on sequences of the mitochondrial, chloroplast and nuclear genome (Chapter $2 \& 3$ ). The distribution of these genetic species with clear biogeographic breaks (Chapter 3) and their inability to float suggests that $L$.

variegata is a poor disperser. A genetic break between two species of L. variegata was found south of Cook Strait, thus one species (L. variegata/Wellington lineage (W)) was confined to the central eastern region of New Zealand while spanning Cook Strait. In this study, I will use newly designed microsatellite markers (Chapter 4) to address questions of population structure and differentiation in one genetic species of L. variegata (L. variegata/W) around Cook Strait.

\subsection{Material and Methods}

Lessonia variegata was collected from five locations around Cook Strait and one location on the southeast coast of the North Island (Fig. 5.1). Within each location, I sampled different sites following a sampling design with increasing distances from 0 to $1000 \mathrm{~m}$ (Fig. 5.1, inserts). Five sites were sampled at Cape Terawhiti, Moa Point, Turakirae Head, and Cape Palliser, three sites at Fighting Bay, and two sites at Mataikona. On average, ten samples (4 to 17) were collected at each site within 10$15 \mathrm{~m}^{2}$, dried in silica gel and returned to the laboratory. Fighting Bay, on the South Island, is separated from the other populations by Cook Strait. The closest population on the opposite side of Cook Strait is Cape Terawhiti, which is located 
$36 \mathrm{~km}$ to the east, at the southwest corner of the North Island. Moa Point is $18 \mathrm{~km}$ further to the west of Cape Terawhiti. Another $14 \mathrm{~km}$ to the southwest is Turakirae Head, which is separated from Moa Point by the Wellington harbour. Cape Palliser is the southernmost point of the North Island and $37 \mathrm{~km}(53 \mathrm{~km}$ along the coast) southeast of Turakirae Head. A large bay, Palliser Bay, and a long beach $(20 \mathrm{~km})$ separates Turakirae Head and Cape Palliser. Mataikona on the east coast is $127 \mathrm{~km}$ to the northeast of Cape Palliser along a continuous rocky coastline.

DNA was extracted following a modified CTAB protocol (Zuccarello \& Lokhorst 2005). PCR amplification was performed as described in Chapter 4 for five microsatellite markers, which have been developed chiefly for this species $(02 \mathrm{~A}$, 09B, 25C, 33D, and 57B (for primer information see Chapter 4, Table 4.1)). PCR products were pooled and subsequently genotyped on an ABI 3730 Genetic Analyser with an internal GS 500 LIZ size standard (Allan Wilson Centre, Palmerston North).

Variations in size have been scored in PEAK SCANNER version 1.0 (https://products.appliedbiosystems.com/ab/en/US/adirect/ab?cmd=catNavigate2\&ca $\underline{\mathrm{tID}=603624)}$ ) and binned using MSAT-ALLELE ver. 1.01 (Alberto 2009). Prior to statistical analysis, the binned scores were double checked for scoring errors and null alleles with MICRO-CHECKER ver. 2.2.3 (Van Oosterhout et al. 2004). Null alleles were corrected using Brookfield 1 method (Brookfield 1996) implemented in MICRO-CHECKER. Brookfield 1 method was selected from a range of other correction methods as all samples used were sucessfully amplified. Linkage disequilibrium was tested against 1.000 permutations using ARLEQUIN ver 3.5.1.2 (Excoffier et al. 2005). 
CONVERT ver. 1.31 (Glaubitz 2004) was used to create input files for analytical softwares and to transfer data matrixes between softwares.

ARLEQUIN ver. 3.5 (Excoffier et al. 2005) was used to calculate deviations from Hardy-Weinberg equilibrium (HWE), and linkage disequilibrium, as well as the amount of observed $\left(\mathrm{H}_{\mathrm{O}}\right)$ and expected heterozygosities $\left(\mathrm{H}_{\mathrm{E}}\right)$ (Table 5.1). Test probabilities were corrected according to Bonferroni procedures (Rice 1989).

Genetically structured populations were defined using STRUCTURE ver. 2.3.3 (Pritchard et al. 2000). Using a Bayesian approach this program assigns posterior probabilities $(\mathrm{L}(\mathrm{K}))$ after sorting individuals based on their genotypes at multiple loci into a predefined number of clusters (K). To compute the probability of the data, I set the number of Markov chain Monte Carlo repeats to 5 million after a burnin period of 10,000 generations. The allele frequency prior, lambda $(\lambda)$, was calculated for each dataset in an extra run with $\mathrm{K}$ set to 1 and was used in further runs as a fixed value. The admixture model was used to account for possible migration between clusters, for the same reason allele frequencies were assumed to be correlated between subpopulations. The best fitting K value, averaged over 10 independent runs, was selected with an algorithm designed to detect the uppermost level of structure, transforming $\mathrm{L}(\mathrm{K})$ over three steps into $\Delta \mathrm{K}$ (Evanno et al. (2005). However, instead of using the average of the absolute values of L"(K) (Evanno et al. 2005), I defined the numerator contributing to $\Delta K$ as the absolute value taken from the average of all L"(K)'s. The original formula would not calculate an average value of $L "(K)$ if both, positive and negative values are found for $L "(K)$ in different runs (e.g., if $\mathrm{L}(\mathrm{K}+1)$ shows high variation between parallels) whereas the average is calculated if all L"(K) values are either positive or negative. Thus the real $\mathrm{K}$ value 
would not only depend on the change of differentiation between the posterior probabilities of successive Ks but also on the standard deviation of $L(K+1)$. However, this is in contrast to the underlying principle of $\Delta \mathrm{K}$ as formulated elsewhere in the article by Evanno et al. (2005), thus I assume the formula in the original article might have been wrongly phrased. This differentiation has proven to be critical for better detection of the number of clusters, comparable to principle component analysis (PCA) and/or results from AMOVA and the true $\mathrm{K}\left(\mathrm{K}^{*}\right)$ was not found with the former but with the later formulation of $\Delta K$. Outputs of multiple STRUCTURE runs were combined in CLUMPP ver. 1.1.2 (Jakobsson \& Rosenberg 2007), and graphically optimised with DESTRUCT ver. 1.1 (http://rosenberglab.bioinformatics.med.umich.edu/distruct.html). CLUMPP input files were generated using STRUCTURE HARVESTER ver. 0.56.4 (http://taylor0.biology.ucla.edu/struct harvest/).

To evaluate the degree of structure among the samples, I additionally performed a principle component analysis coding each locus as an independent variable combining the three-number code that described the length of each allele per locus into a six-number code for each individual. Thus I created a matrix with five columns (the number of microsatellite markers used). Through the variable reduction procedure of the principle component analysis (PCA), an artificial matrix consisting of only two columns was created while accounting for most of the variation within the data. Due to the sample size I only plotted the centre of gravity for each site to make the figure easier to read.

Hierarchical AMOVA was calculated in ARLEQUIN ver. 3.5.1.2 (Excoffier et al. 2005) and used to conduct three different series of tests according to different 
spatial levels. In all tests I performed $\mathrm{R}_{\mathrm{ST}}$-like analysis. To add information about the relatedness of alleles for $\mathrm{R}_{\mathrm{ST}}$-like analysis, the allele-code had to be converted from the length of the marker sequence into the number of microsatellite repeats. Thus I had to use a dataset that was not corrected for null-alleles as for null-alleles the length or count is unknown. The first series of analyses was performed to evaluate the genetic structure of L. variegata populations in Cook Strait compared with the STRUCTURE output. Therefore I calculated the percentage of variation among different groupings of locations $\left(\mathrm{F}_{\mathrm{GT}}\right)$. Highest $\mathrm{F}_{\mathrm{GT}}$ combined with lowest $\mathrm{F}_{\mathrm{LG}}$ (variation among locations within groups) would indicate maximised differentiation between groups together with minimized differentiation within groups, and thus the best combination of groups of locations. A crude index $\left(\mathrm{F}_{\mathrm{GT} / \mathrm{LG}}\right)$ was created to make the best combination salient, therefore I compared the absolute values of $\mathrm{F}_{\mathrm{GT}}$ divided by $F_{L G}$ (i.e., $F_{G T / L G}=\left|F_{G T} / F_{L G}\right|$ ) between all combinations tested. The next series of tests was performed to find potential substructure within clusters and groups defined with STRUCTURE (i.e., within the Cook Strait cluster (Fighting Bay, Cape Terawhiti, Moa Point and Turakirae Head), the Greater Wellington group (Cape Terawhiti, Moa Point and Turakirae Head), and the Wairarapa cluster (Cape Palliser and Mataikona)). In the third series of tests, small scale variation within locations and sites was evaluated. Pair-wise $\mathrm{R}_{\mathrm{ST}}$ was performed for all sample sites in ARLEQUIN to additionally evaluate population genetic structure between sites within locations and among locations.

The three different methods (STRUCTURE, PCA, and hierarchical AMOVA) were used to evaluate connectivity, and breaks between and within the locations sampled. As one method (the detection of $\mathrm{K}^{*}$ (the real number of clusters 
within a dataset)) was slightly modified, the other methods were also used to confirm the results that were affected by this modification. STRUCTURE was used hierarchically similar to AMOVA to further investigate clusters for groups and subgroups. Breaks found with STRUCTURE at the first hierarchical level (using an undivided dataset) were used to define "clusters". Subsequently the dataset was divided according to these clusters and reanalysed. Breaks found at the second hierarchical level were used to define "groups", so that the terminology gives an indication to the hierarchical level of the structure found. With the additional use of $\Delta \mathrm{K}^{*}$, (which is proposed to measure the signal strength of a break (Evanno et al. 2005)), STRUCTURE results of pairwise tests were interpreted as a measure of connectivity between groups. This is similar to the use of a pairwise $\mathrm{R}_{\mathrm{ST}}$ matrix in combination with AMOVA results, where the mean pairwise $\mathrm{R}_{\mathrm{ST}}$ value between groups of interest gives an indication of the degree of differentiation. The significance of the degree of differentiation was tested with a 2-tailed t-test comparing pairwise $\mathrm{R}_{\mathrm{ST}}$ within groups with pairwise $\mathrm{R}_{\mathrm{ST}}$ between groups. In turn, three series of subsequent hierarchical AMOVA were used to verify and confirm STRUCTURE results, however the third series allowed additional interpretations (e.g., the evaluation of inbreeding) and the evaluation of structure at a finer scale (e.g., among individuals within locations). PCA was used to evaluate the variation within a dataset without using information about genetic inheritance and dependence of the data.

\subsection{Results}

No significant deviation from HWE was found except for the locus 57B within the Mataikona population (Table 5.1). If significant deviations from HWE result from 
local inbreeding or admixture then deviations should be found at all loci. As in this population only one marker (57B) departed significantly from HWE this might indicate the presence of null alleles rather than the result of local breeding structure or admixture (Van Oosterhout et al. 2006).

Among the four possible scoring errors that can be detected using MICROCHECKER (typographical errors, stuttering, large allele dropout, and null alleles) only null alleles were apparent in the data set. A total of 11 corrections have been suggested (Table S 5.1), one for the locus 57B for a sample from Mataikona, and ten for the locus 09B (affecting six alleles from Turakirae Head and four from Fighting Bay). However no evidence for null alleles was found within the Cook Strait Cluster or Greater Wellington Group. Thus, as Turakirae Head and Fighting Bay were within these groups of connected locations (see below), no corrections were made for locus 09B. Linkage disequilibrium (Table S 5.2) was found in Cape Terawhiti between loci $02 \mathrm{~A}$ and $25 \mathrm{C}$; however, as linkage was not found in any other population or any other pair of loci it might be an artefact of common evolutionary history rather than an artefact of linked loci.

Allele variability differed between loci from 6 to 31 alleles (at locus 09B and 33D, respectively). Private alleles were detected (Table S 5.3) with a maximum of 9 private alleles found for the locus 33D within samples from Cape Palliser.

Structure and substructure was found using hierarchical STRUCTURE analysis and a modified algorithm based on Evanno et al. (2005) (Fig. 5.2-5.4). In addition, $\Delta \mathrm{K}^{*}$ (defining $\mathrm{K}^{*}$ as the real number of clusters within a dataset) of the modified Evanno transformation could be used as an indicator of the strength of the signal detected by STRUCTURE (Evanno et al. 2005) (Fig. $5.5 \& 5.6$ ). At the 
uppermost hierarchical level, a separation was indicated between a cluster comprising Cape Palliser and Mataikona (hereafter called the Wairarapa Cluster, WC in Fig. 5.2) and locations sampled in inner Cook Strait (Fighting Bay, Cape Terawhiti, Moa Point, and Turakirae Head; hereafter called the Cook Strait Cluster, CSC in Fig. 5.2). This was the strongest break found during hierarchical testing with $\Delta \mathrm{K}^{*}=100$. Within the Wairarapa Cluster the locations Mataikona and Cape Palliser formed separate groups at the second hierarchical level $\left(\Delta K^{*}=83\right.$, Fig. 5.3). Fighting Bay was separated from the remaining locations of the Cook Strait Cluster at the second hierarchical level $\left(\Delta \mathrm{K}^{*}=64\right.$, Fig. 5.3). The remaining locations (Cape Terawhiti, Moa Point, and Turakirae Head) were not further structured (Fig. 5.4) and are hereafter called Greater Wellington Group. STRUCTURE and $\Delta \mathrm{K}^{*}$ were also used to estimate the strength of breaks between locations or group of locations. A pairwise test of locations within the Cook Strait Cluster was conducted to evaluate the connectivity of the Greater Wellington Group locations to Fighting Bay (Fig. 5.5). The highest $\Delta \mathrm{K}^{*}$ found was between Fighting Bay and Turakirae Head $\left(\Delta \mathrm{K}^{*}=75\right)$. Five times smaller was the value between Fighting Bay and Cape Terawhiti $\left(\Delta \mathrm{K}^{*}=14\right)$ and no differences were found between the other comparisons $\left(\mathrm{K}^{*}=\mathrm{K} 1\right)$ including the comparison between Fighting Bay and Moa Point. I also tested the connectivity of locations or groups of locations to Cape Palliser (Fig. 5.6). The lowest $\Delta \mathrm{K}^{*}$ was found between Cape Palliser and Fighting Bay $\left(\Delta \mathrm{K}^{*}=28\right)$. These two locations are $98 \mathrm{~km}$ apart with the Greater Wellington Group between them. In comparison the signal between Cape Palliser and Turakirae Head, its geographically closest neighbour, was 10 times stronger $\left(\Delta K^{*}=290\right)$. The strongest signal, however, was found between Cape Palliser and the Greater Wellington Group $\left(\Delta \mathrm{K}^{*}=888\right)$. 
Principle component analyses revealed three different clusters explaining $54.80 \%$ of the variation in the dataset (Fig. 5.7; showing the centre of gravity of sample sites). The first component (explaining $29.71 \%$ of the total variance) clearly separated the samples from Mataikona, Cape Palliser, and the remaining Cook Strait samples into three different groups. Whereas the second axis (explaining 25.09\%) separated the Cook Strait Cluster from the Wairarapa Cluster. Thus, both axes supported a differentiation between the Wairarapa Cluster and the Cook Strait Cluster, which are geographically separated by Palliser Bay. The separation between Cape Palliser and Mataikona was mainly supported by the first and less by the second factorial axis; the two locations are geographically $127 \mathrm{~km}$ apart, and connected continuous rocky coastline.

The first series of AMOVA tests was designed to evaluate the amount of structure within the dataset. Therefore the percentage of variation was calculated for different groupings of locations (Table 5.2). High $\mathrm{F}_{\mathrm{GT}}$ (differentiation among groups) would be an indicator for a good grouping regime and low $\mathrm{F}_{\mathrm{LG}}$ (differentiation within groups) would indicate little substructure. Thus I explored the dataset for a combination of maximised $\mathrm{F}_{\mathrm{GT}}$ and minimized $\mathrm{F}_{\mathrm{LG}}$ values. The highest $\mathrm{F}_{\mathrm{GT}}$ value was found for the grouping $[\mathrm{Fi} / \mathrm{Te} / \mathrm{Mo} / \mathrm{Tu}][\mathrm{Pa}][\mathrm{Ma}]$ (test No. 4 ), which equals the grouping found with the first two components of PCA. However, the AMOVA also resulted in a low but significant $F_{L G}$ value, indicating further substructure among populations within groups, in this case within the Cook Strait Cluster ([Fi/Te/Mo/Tu]). The only non-significant $F_{L G}$ value (indicating no further substructure within the defined groups) combined with the second highest $\mathrm{F}_{\mathrm{GT}}$ (0.5257; $\mathrm{p}<0.0001)$ was found for the grouping $[\mathrm{Fi}][\mathrm{Te} / \mathrm{Mo} / \mathrm{Tu}][\mathrm{Pa}][\mathrm{Ma}]$ (test No. 6). 
Test No. 6 had also the highest $\mathrm{F}_{\mathrm{GT} / \mathrm{LG}}$ value and this conformed to the clusters and groups found with hierarchical STRUCTURE analysis. Thus the first test series of AMOVA supported the clusters and groups found with STRUCTURE und PCA.

The second series of AMOVA tests was performed to test for substructure within clusters and groups defined from the STRUCTURE results. Different combinations of groupings were tested between locations of the Cook Strait Cluster but only one combination was found with a significant $\mathrm{F}_{\mathrm{GT}}$ value (Table $\mathrm{S}$ 5.4A). No significant variation was found among locations of the Greater Wellington Group (Table S 5.4B) and a high $\mathrm{F}_{\mathrm{LT}}$ denoted significant variation between locations of the Wairarapa Cluster (Table S 5.4C). Thus no additional substructure was found with the second test series that was not already found in the first series of tests.

The third series of AMOVA tests was designed to evaluate the differentiation among sites within locations (Table S 5.5). Significant differentiation among sites $\left(\mathrm{F}_{\mathrm{ST}}\right)$ would indicate isolation into small populations within hundreds of meters, whereas high variation within sites $\left(\mathrm{F}_{\mathrm{IS}}\right)$ might indicate structure even within 10 to $15 \mathrm{~m}^{2}$. However, no significant variation was found within any location at any spatial level.

Pairwise $\mathrm{R}_{\mathrm{ST}}$ estimates showed a moderate number of significant differences (Table 5.3). Genetic differentiation was strong between clusters (121 out of 126 comparisons have been significant) and strong to moderate within clusters between groups (between Cape Palliser and Mataikona 8 out of 10 comparisons were significant and between Fighting Bay and Greater Wellington Group 8 out of 45), however, no significant differences were found between sites within locations and between sites within groups. A two-sided t-test was used to evaluate the strength and 
significance of the breaks found. The t-test was used to compare the variation within groups to the variation between groups (Table 5.3 insert). The highest value was found in the comparison between clusters $(0.441 ; \mathrm{p}<0.0001)$ indicating the strongest break. Within clusters between groups the t-test resulted a value of $0.409(p<0.0001)$ and $0.104(\mathrm{p}<0.0001)$, for the comparison between Cape Palliser and Mataikona and between Fighting Bay and GWG, respectively. The latter results are an indication for a stronger break between the Eastcoast populations then between the CSC populations. Thus the pairwise $\mathrm{R}_{\mathrm{ST}}$ estimates together with the 2-sited t-tests of pairwise $\mathrm{R}_{\mathrm{ST}}$ values (Table 5.3 insert) confirmed the results found with the three hierarchical levels of STRUCTURE analysis.

\subsection{Discussion}

Although it was assumed that Lessonia is a poor disperser (Faugeron et al. 2005) I found no genetic differentiation within sites (within $10 \mathrm{~m}^{2}$ ) nor between sites within locations (i.e., sites that are separated by 100 to $1,000 \mathrm{~m}$ ). However, small scale genetic variation cannot be ruled out and might be detected with a larger number of microsatellite markers. The small scale genetic variations as detected in other Lessonia species, such as L. nigrescens (Faugeron et al. 2005 [within 20m]), or in other Laminariales, such as Postelsia palmaeformis (Dayton 1973 [<3m], Kusumo et al. $2006[<5 \mathrm{~m}])$, reflect supposedly the dispersal by zoospores and sperms (propagules). Propagule dispersal followed by successful recruitment of juveniles is governed by restrictive mechanisms in Laminariales, e.g., their complex life cycle requires male and female gametophytes to be in close vicinity for successful fertilisation (Reed 1990). Some factors that restrict dispersal of propagules are summarized in Santelices (1990). However, other forms of dispersal e.g., drifting or 
floating of detached algae or fertile fragments, rafting attached to other floating devices as well as dispersal by saltation are reported for Laminariales (Dayton 1973, Schiel and Foster 1986, van den Hoek 1987, Santelices 1990, Reed et al. 1992, Faugeron et al. 2005, Lane \& Saunders 2005, Macaya et al. 2005, Kusumo et al. 2006, Sliwa et al. 2006). Dispersal of free-floating spores should not be underestimated, as spores can develop into planktonic gametophytes that can become fertile and retain the ability to produce sporophytes after fertilization (Reed et al. 1992). These other forms of dispersal might be responsible for the lack of genetic structure found in this survey. For example, I detected only weak genetic differentiation between populations on either side of Cook Strait separated by a $>36 \mathrm{~km}$ broad waterway and no significant differences between populations within a $32 \mathrm{~km}$ long, more or less continuous coast line on the south of the North Island (i.e., within the Greater Wellington Group). Strong tidal currents, eddies, and rips (Heath 1971, Bowman et al. 1980) but also wind stress (Bowman et al. 1983) within Cook Strait might assist good connectivity between these populations. The connectivity found between Cook Strait locations is of the same magnitude but slightly smaller than the differentiation found in Ecklonia radiata on the South coast of Australia (Coleman et al. 2009). Coleman et al. (2009) used six microsatellite markers to detect small scale [within 10s of $\mathrm{km}$ ] genetic variation in Ecklonia radiata. These two related algae might have similar dispersal abilities as they possess no floating devices, are of comparable size, and share partially overlapping habitats. In contrast, large brown algae with floating devices, like pneumatocysts in Macrocystis pyrifera or gas-filled honeycomb structures in the blades of Durvillaea antarctica, have shown extreme connectivity throughout the Southern Hemisphere with little to no 
differentiation between populations within the Antarctic Circumpolar Current (Macaya \& Zuccarello 2010, Fraser et al. 2009).

The strongest break found was between Turakirae Head and Cape Palliser. These two populations are separated by $37 \mathrm{~km}$ ( $53 \mathrm{~km}$ along the coast) across Palliser Bay. There is no obvious evidence for inhibited connectivity through surface currents (pers. comm. with Craig Stevens and Mark Hadfield, Marine Physicists from New Zealand National Institute for Water and Atmospheric Research) but the populations are separated by a 15 to $20 \mathrm{~km}$ long beach of unsuitable substrate consisting of mudstone and/or sandstone in combination with a river delta in the middle of the bay (http://sci.waikato.ac.nz/evolution/images/geology_era.pdf). The width of Palliser Bay is comparable to the width of Cook Strait however the genetic differences found are significantly stronger (4 to 14 times stronger, dependent on the method used, i.e., mean $\mathrm{R}_{\mathrm{ST}}=0.1042$ between $[\mathrm{Fi}][\mathrm{Te} / \mathrm{Mo} / \mathrm{Tu}]$ and 0.4067 between $[\mathrm{Te} / \mathrm{Mo} / \mathrm{Tu}][\mathrm{Pa}]$ showing significant differences at $\mathrm{p}<0.0001 ; \Delta \mathrm{K} 2=64$ between $[\mathrm{Fi}][\mathrm{Te} / \mathrm{Mo} / \mathrm{Tu}]$ and 888 between $[\mathrm{Te} / \mathrm{Mo} / \mathrm{Tu}][\mathrm{Pa}])$. This is in contrast to suggestions made by Coleman et al. (2009) who found that differences in gene flow were comparable between vast tracts of unsuitable coastline and where oceanic expanses existed. One explanation could be that stronger currents and turbulences within Cook Strait increase connectivity, explaining both the low genetic differentiation across Cook Strait and the insignificant differences among the Greater Wellington populations along the Cook Strait coast. Another explanation could be that steep variations in bathymetry (i.e., the Wairarapa canyon on the west side of Palliser Bay) might influence near-shore flows through the vertical flows they generate (Craig Stevens, pers. comm.). Even though there are no obvious anomalies in the surface 
currents within Palliser Bay that would explain a constant barrier to gene flow, the Wairarapa canyon would prevent some of the many possible dispersal mechanisms. The genetic differentiation on these two breaks is probably a combination of many unknown causes and influencing factors (Santelices 1990). Cook Strait and the Wairarapa canyon in Palliser Bay could prevent dispersal via saltation as proposed for intermediate dispersal over moderate distances (10-100m per year) in Undaria pinnatifida (Sliwa et al. 2006). Both Cook Strait and the Wairarapa canyon also prevent dispersal of drifting algae, which tumble over the seafloor, as they are too heavy to float. This form of dispersal is limited to shallow water (Thiel \& Gutow 2005a). Thus dispersal across Cook Strait and Palliser Bay might be limited to rafting, and via floating spores or spore aggregates. Floating spores have been reported to travel at least $4 \mathrm{~km}$ (Reed et al. 1988,), which is only a fraction of the $36 \mathrm{~km}$ needed. However, the maximum range of spore dispersal in nature is still unknown based on the difficulties in detecting spores in the water column (Reed et al. 2004). But successful settlement and fertilisation success decreases with time and distance based on several affecting factors like planktonic grazing, the dilution effect, and loss of stickiness (Santelices 1990). Thus I might speculate that a likely form of dispersal is rafting (i.e., the attachment of microscopic gametophytes or macroscopic sporophyte to other floating devices), which might be favoured by the stronger currents and turbulences within the Cook Strait narrows and thus explain the differences in genetic differentiation found between the two barriers, Cook Strait and Palliser Bay. 


\subsection{Conclusion}

The aim of this study was to investigate the connectivity across Cook Strait in comparison to the connectivity of populations along a continuous coastline.

Therefore I sampled six locations, one on the South Island and five along the southeast coast of the North Island (Fig. 5.1). To explore the genetic diversity I used five newly developed microsatellite markers (Chapter 4). Cook Strait was found to be only a weak barrier to gene flow enabling connectivity between Fighting Bay and the Greater Wellington Group. In general, connectivity was high within the Cook Strait Cluster and no differentiation was found within the Greater Wellington Group, which consists of three sample locations distributed along a $32 \mathrm{~km}$ long coast line. However, a strong break was found at Palliser Bay between the Cook Strait Cluster and the Wairarapa Cluster. Strong currents within Cook Strait might be the reason for increased connectivity across Cook Strait compared to connectivity across Palliser Bay where currents are weaker. 


\subsection{Figures \& Tables}

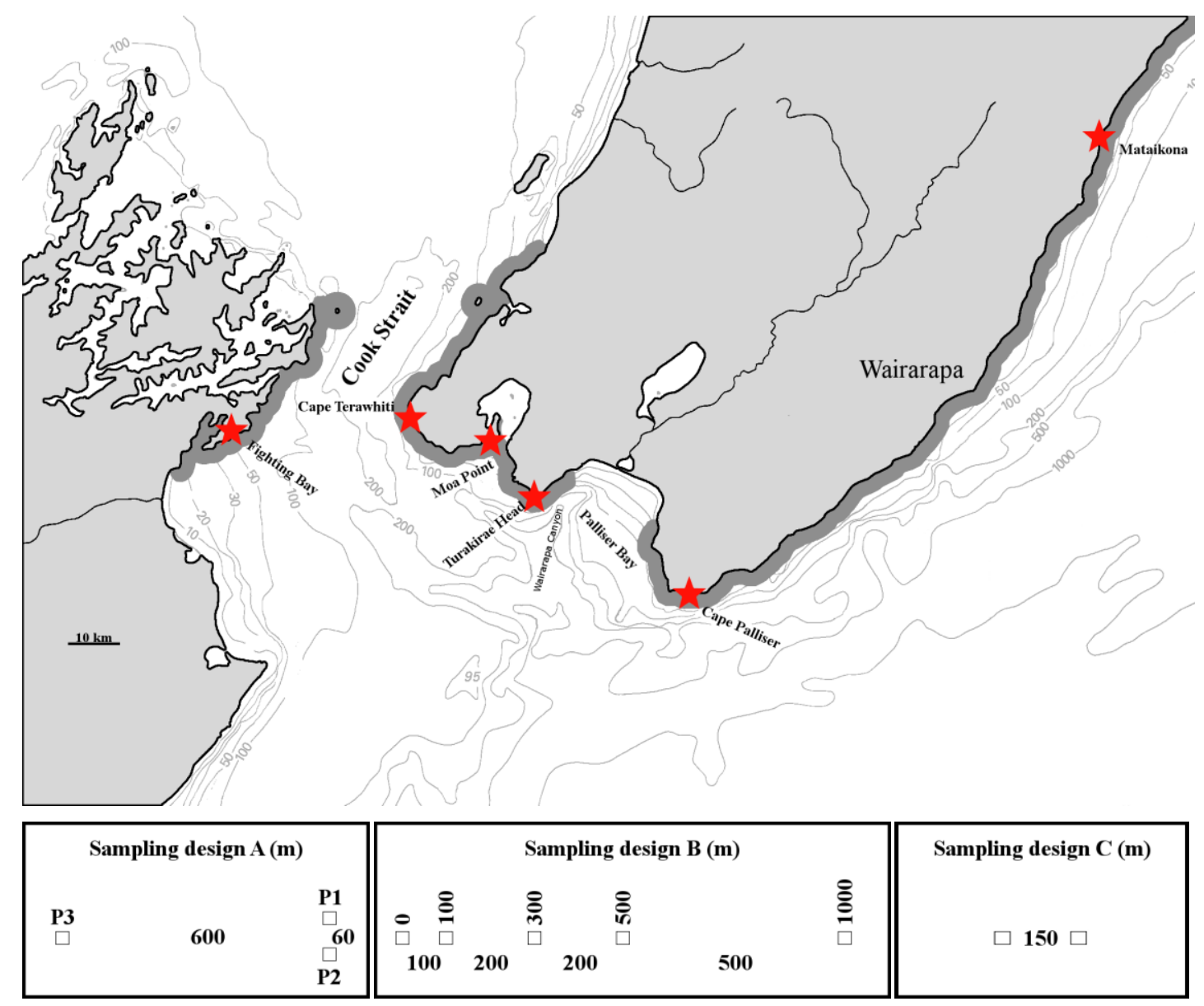

Fig. 5.1 Sample locations (stars) and different sample designs (A-C). Dark grey outlined is the distribution of Lessonia variegata/W in the area. Sampling design A was applied to Fighting Bay; sampling design B with increasing distances between sites (quadrats) was applied to the locations Cape Terawhiti, Moa Point, Turakirae Head, and Cape Palliser; sampling design C was used at Mataikona. 


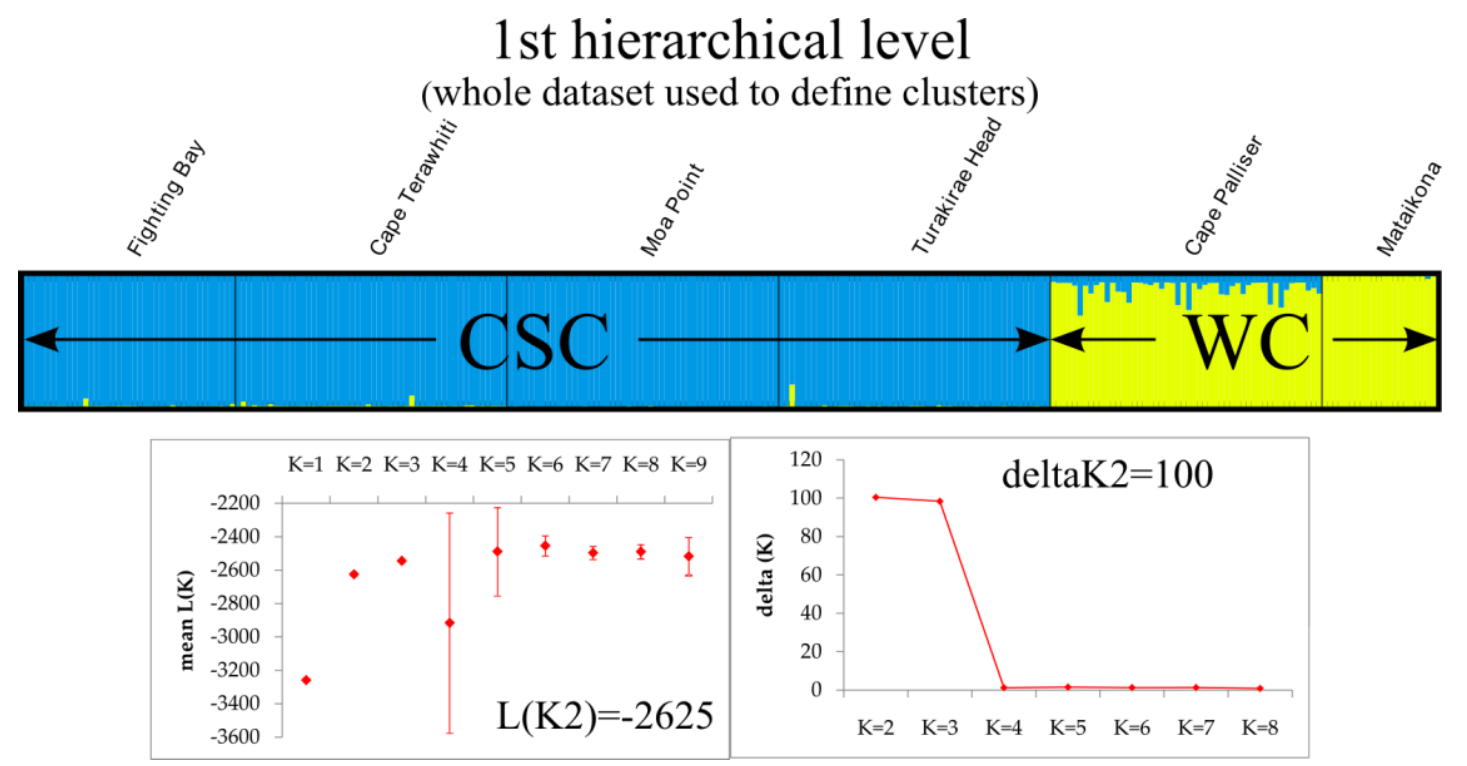

Fig. 5.2 Bar plot and graphs of the genetic population differentiation at the $1^{\text {st }}$ hierarchical level calculated in STRUCTURE. Bar plots show the mean of all replicates of $\mathrm{K}^{*}$ (here $\mathrm{K}=2$ ). Each population is represented by a colour and each sample is represented by a single bar showing its membership coefficient to any population (the height of each bar plot equals 100\%). Left graph shows the mean $\mathrm{L}(\mathrm{K})$ value, right graph shows $\Delta \mathrm{K}$ values using a modified transformation based on Evanno et al. (2005), which calculates the best value of $\mathrm{K}\left(\mathrm{K}^{*}\right)$. The height of the $\Delta \mathrm{K}^{*}$ value indicates the strength of the signal detected by STRUCTURE. CSC Cook Strait cluster, WC Wairarapa cluster. 


\section{2nd hierarchical level}

(within clusters; defining groups)
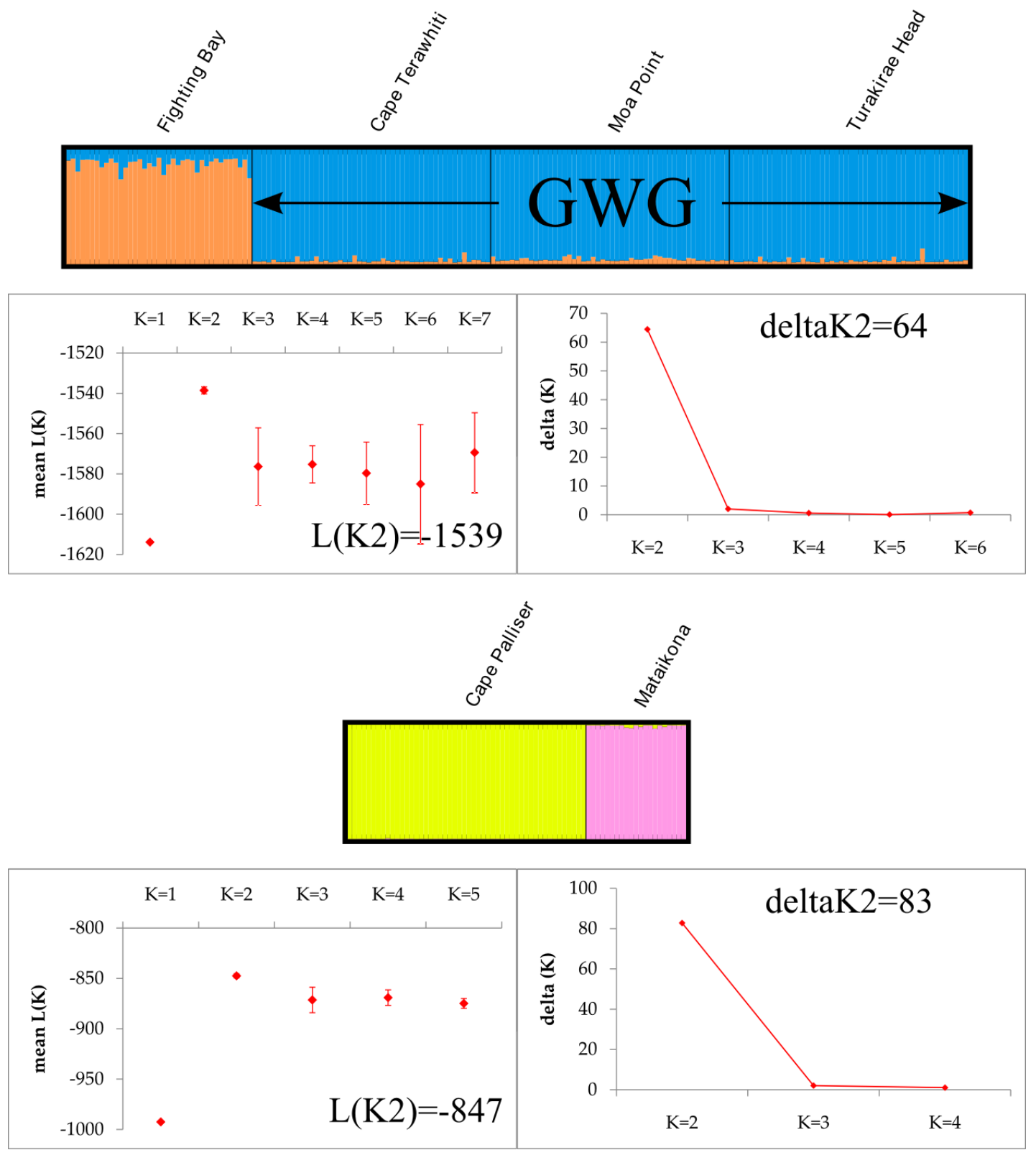

Fig. 5.3 Bar plots and graphs of the genetic population differentiation at the 2nd hierarchical level calculated in STRUCTURE. See Fig. 5.2 for more details. GWG Greater Wellington group. 


\section{3rd hierarchical level}

(within groups)

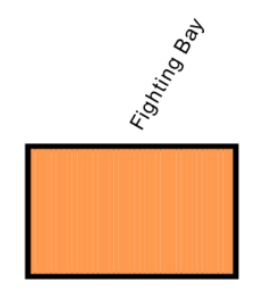

$K=1 \quad K=2 \quad K=3 \quad K=4 \quad K=5 \quad K=6 \quad K=7 \quad K=8 \quad K=9$

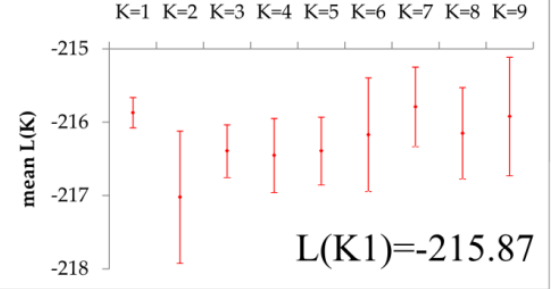

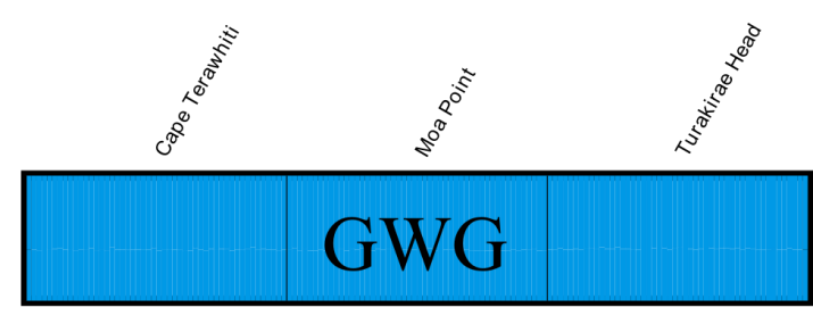
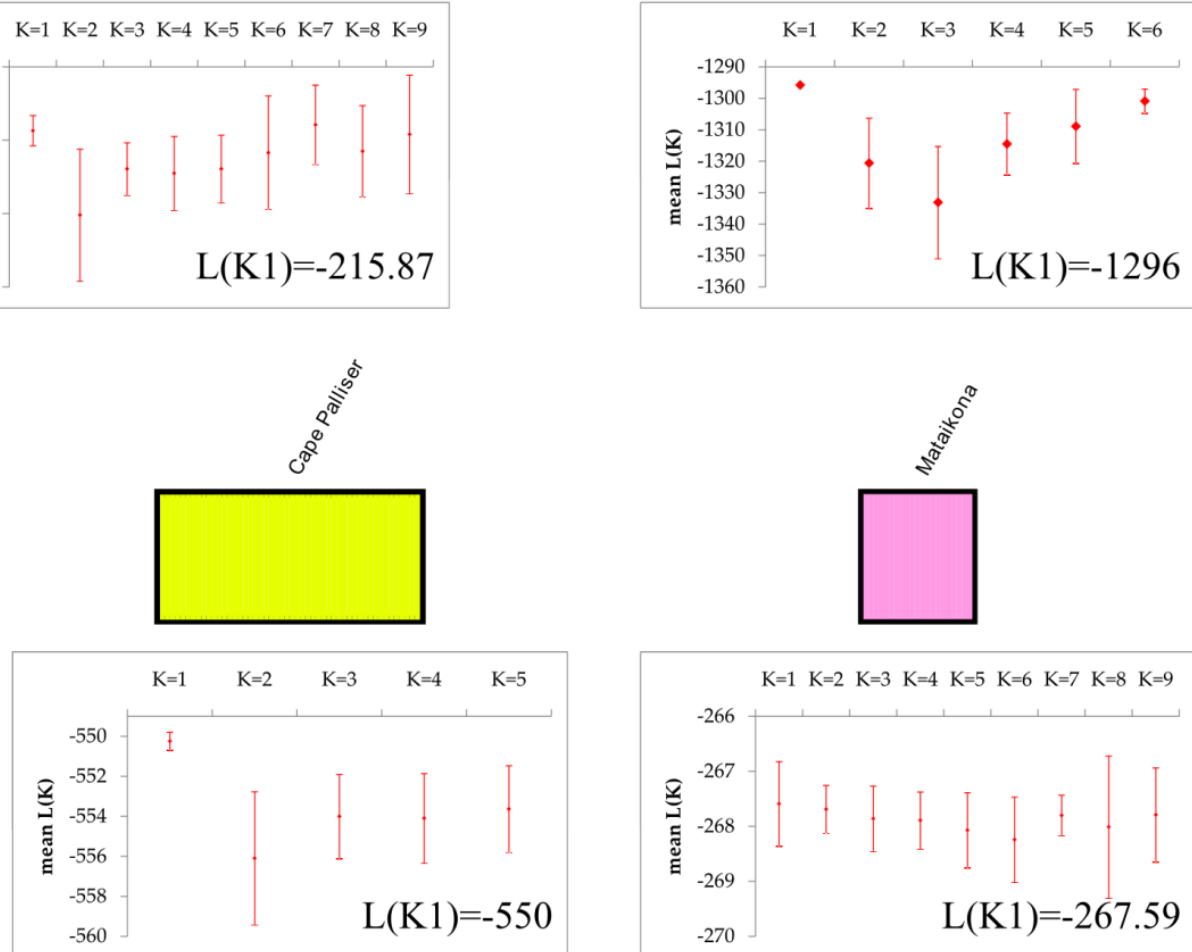

Fig. 5.4 Bar plots and graphs of the genetic population differentiation at the 2nd hierarchical level calculated in STRUCTURE. See Fig. 5.2 for more details. $\Delta \mathrm{K}$ values are not shown as $\mathrm{K}^{*}=1$ (i.e., no substructure was found). GWG Greater Wellington group. 

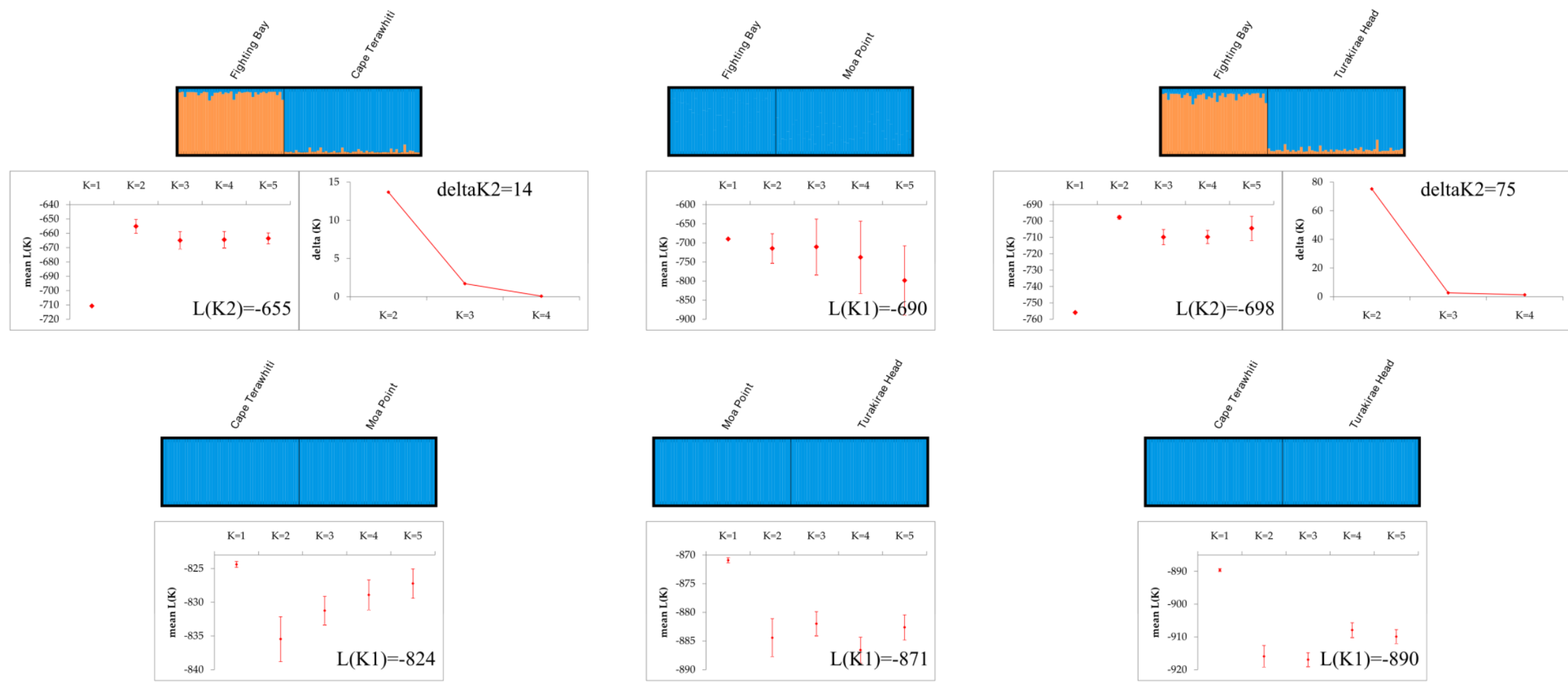

Fig. 5.5 Bar plots and graphs of STRUCTURE results, testing connectivity within Cook Strait cluster. See Fig. 5.2 for more detail. $\Delta \mathrm{K}$ values are only shown if K*>1 (i.e., when substructure was found). 


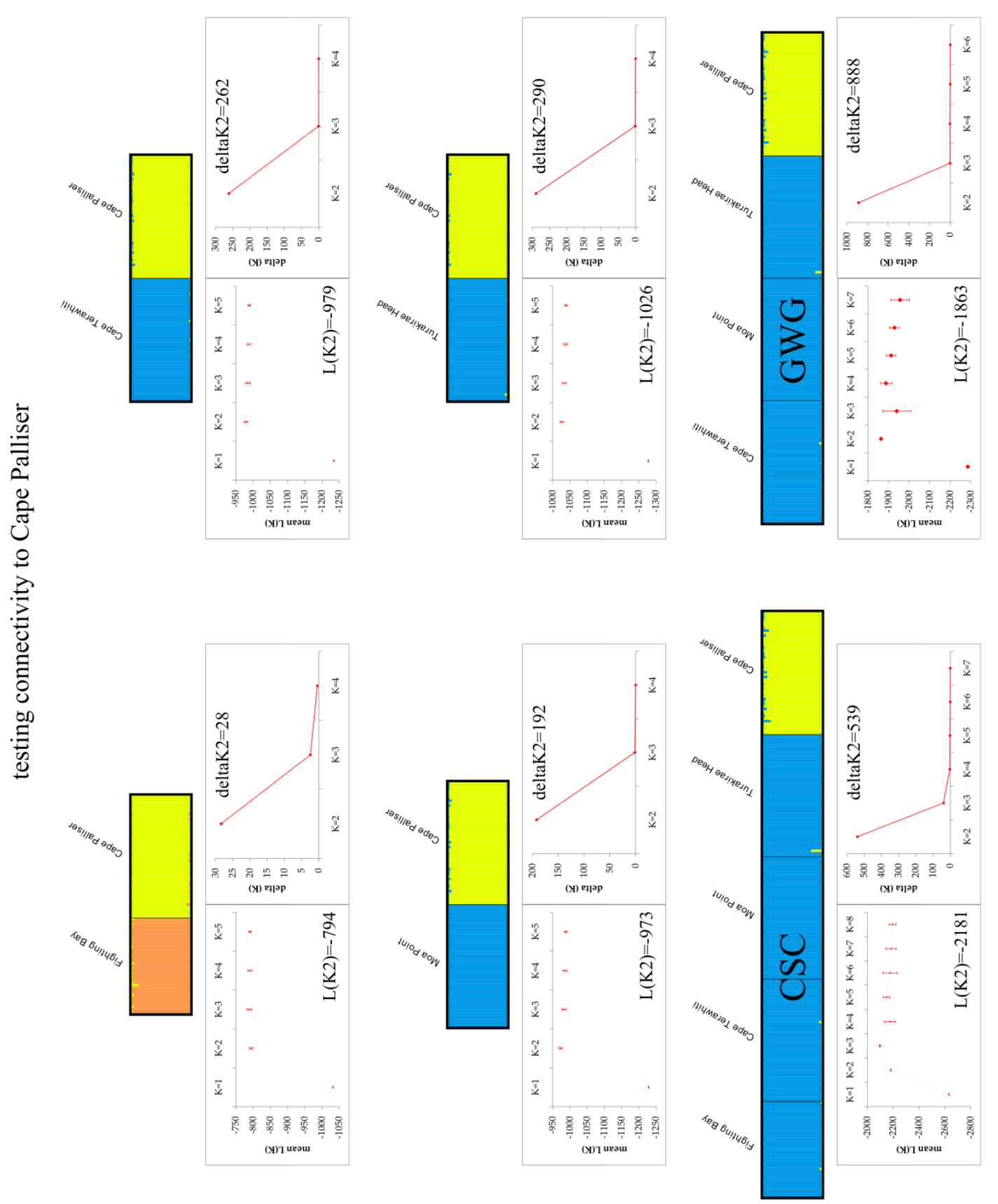

Fig. 5.6 Bar plots and graphs of STRUCTURE results, testing connectivity to Cape Palliser. See Fig. 5.2 for more detail. 


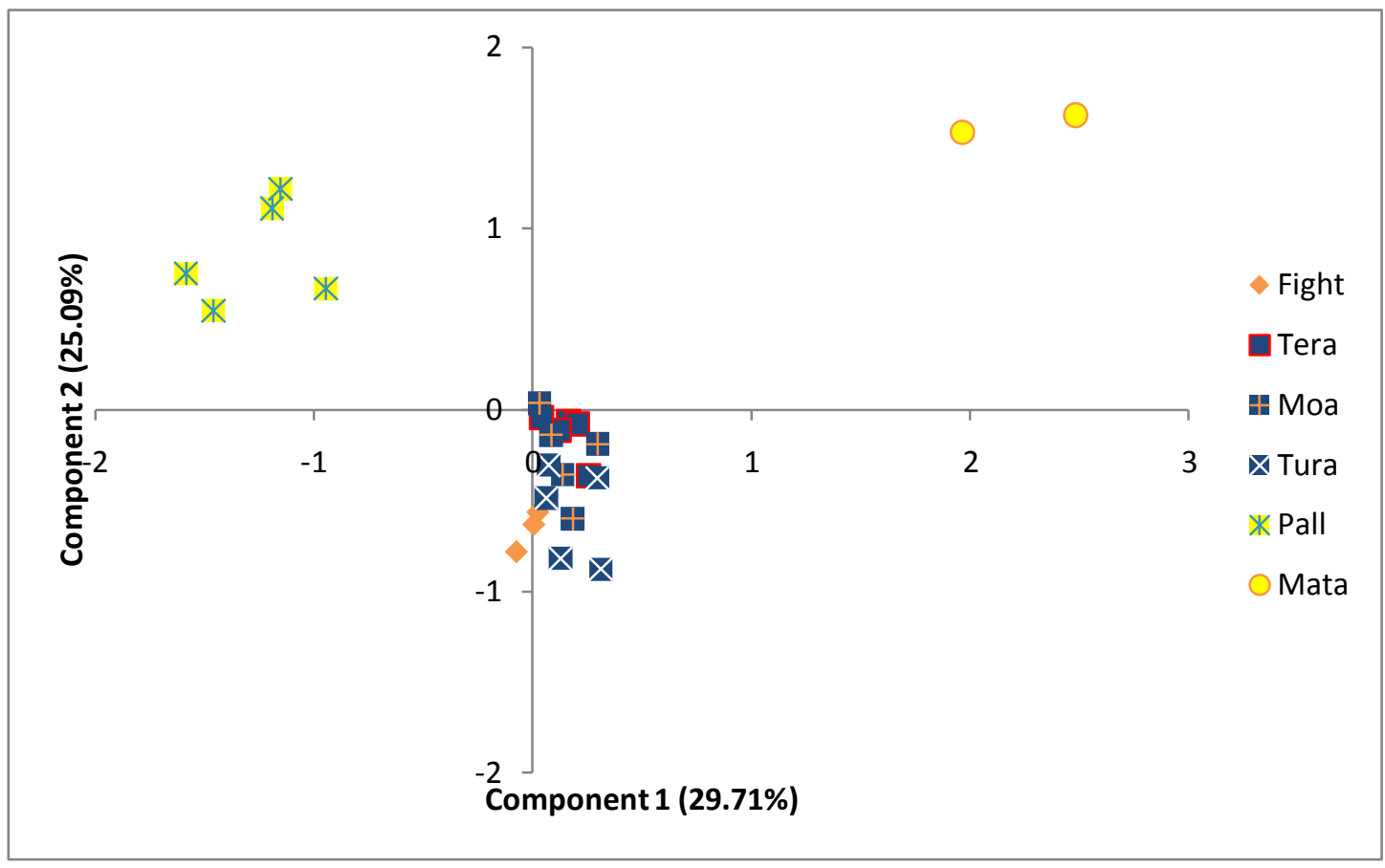

Fig. 5.7 Principle component analysis (PCA). Each point represents the centre of gravity of all samples per site. Total variance is given in parentheses. Fight, Fighting Bay; Tera, Cape Terawhiti; Moa, Moa Point; Tura, Turakirae Head; Pall, Cape Palliser; Mata, Mataikona. 
Table 5.1 Sample size $(N)$, number of alleles per locus and population $\left(\mathrm{N}_{\mathrm{A}}\right)$, observed $\left(\mathrm{H}_{\mathrm{O}}\right)$ and expected $\left(\mathrm{H}_{\mathrm{E}}\right)$ heterozygosity. * significant deviation from $\mathrm{HWE}$ at $\alpha=0.05$ (after sequential Bonferroni correction); $\mathrm{nv}=$ not variable.

\begin{tabular}{|c|c|c|c|c|c|}
\hline Population & $\mathrm{N}$ & Locus & $\mathrm{N}_{\mathrm{A}}$ & $\mathrm{H}_{\mathrm{O}}$ & $\mathrm{H}_{\mathrm{E}}$ \\
\hline \multirow{5}{*}{ Fighting Bay } & 39 & $02 \mathrm{~A}$ & 1 & nv & $\mathrm{nv}$ \\
\hline & 39 & 09B & 2 & 0.20513 & 0.29837 \\
\hline & 39 & $25 \mathrm{C}$ & 5 & 0.15385 & 0.14785 \\
\hline & 35 & $33 \mathrm{D}$ & 7 & 0.57143 & 0.58219 \\
\hline & 39 & $57 \mathrm{~B}$ & 4 & 0.61538 & 0.51449 \\
\hline \multirow[t]{5}{*}{ Cape Terawhiti } & 49 & $02 \mathrm{~A}$ & 3 & 0.04082 & 0.04061 \\
\hline & 50 & 09B & 3 & 0.52000 & 0.48343 \\
\hline & 49 & $25 \mathrm{C}$ & 2 & 0.10204 & 0.13402 \\
\hline & 49 & $33 \mathrm{D}$ & 10 & 0.81633 & 0.78834 \\
\hline & 50 & $57 \mathrm{~B}$ & 7 & 0.58000 & 0.55616 \\
\hline \multirow[t]{5}{*}{ Moa Point } & 50 & $02 \mathrm{~A}$ & 2 & 0.02000 & 0.02000 \\
\hline & 50 & 09B & 2 & 0.44000 & 0.46545 \\
\hline & 50 & $25 \mathrm{C}$ & 4 & 0.22000 & 0.23636 \\
\hline & 47 & $33 \mathrm{D}$ & 11 & 0.80851 & 0.79387 \\
\hline & 50 & $57 \mathrm{~B}$ & 7 & 0.52000 & 0.49232 \\
\hline \multirow[t]{5}{*}{ Turakirae Head } & 50 & $02 \mathrm{~A}$ & 3 & 0.12000 & 0.11495 \\
\hline & 50 & 09B & 2 & 0.36000 & 0.45333 \\
\hline & 49 & $25 \mathrm{C}$ & 4 & 0.28571 & 0.30570 \\
\hline & 49 & $33 \mathrm{D}$ & 10 & 0.73469 & 0.78961 \\
\hline & 50 & $57 \mathrm{~B}$ & 8 & 0.58000 & 0.61232 \\
\hline \multirow[t]{5}{*}{ Cape Palliser } & 50 & $02 \mathrm{~A}$ & 3 & 0.14000 & 0.13273 \\
\hline & 50 & 09B & 3 & 0.24000 & 0.25131 \\
\hline & 50 & $25 \mathrm{C}$ & 5 & 0.72000 & 0.70081 \\
\hline & 48 & $33 \mathrm{D}$ & 16 & 0.81250 & 0.74934 \\
\hline & 50 & $57 \mathrm{~B}$ & 8 & 0.60000 & 0.71394 \\
\hline \multirow[t]{5}{*}{ Mataikona } & 19 & $02 \mathrm{~A}$ & 3 & 0.31579 & 0.35846 \\
\hline & 21 & 09B & 2 & 0.28571 & 0.25087 \\
\hline & 20 & $25 \mathrm{C}$ & 4 & 0.65000 & 0.69103 \\
\hline & 18 & $33 \mathrm{D}$ & 15 & 1.00000 & 0.93810 \\
\hline & 20 & $57 \mathrm{~B}$ & 7 & $0.60000 *$ & 0.82564 \\
\hline
\end{tabular}


Table 5.2 First series of AMOVA tests exploring variation within dataset. Groupings of locations are given in brackets. Highest $\mathrm{F}_{\mathrm{CT} / \mathrm{SC}}$ was found in Test No. 6. Fi, Fighting Bay; Te, Cape Terawhiti; Mo, Moa Point; Tu, Turakirae Head; Pa, Cape Palliser; Ma, Mataikona; SS, Sum of squares; *, p<0.05; **, $\mathrm{P}<0.001 ; * * *, \mathrm{p}<0.0001 ;{ }^{\mathrm{ns}}$, not significant.

Test No. 1: [Fi/Te/Mo/Tu/Pa/Ma

Among locations $\quad 11297.2$

Among individuals

8667

$\%$ variation

Fixation indices

within locations

Within individuals

\section{5}

28418.7

$44.09344 \quad \mathrm{~F}_{\mathrm{LT}}=0.44093 * * *$

Total

$\mathrm{F}_{\mathrm{IL}}=0.02428^{\mathrm{ns}}$

Test No. 2: [Fi/Te/Mo/Tu/Pa][Ma] $\mathrm{F}_{\mathrm{GT} / \mathrm{LG}}=1.1$

Among groups

Among locations

within groups

Among individuals

within locations

Within individuals

Total

3581.4

7715.8

41.19609

22.04104

8667

0.89276

8454.5

35.87011

28418.7

Test No. 3: [Fi/Te/Mo/Tu][Pa/Ma] $F_{G T / L G}=0.5$

Among groups

Among locations

4342.8

18.55871

6954.4

30.91662

within groups

Among individuals

within locations

Within individuals

Total

$$
8667
$$

1.22695

8454.5

49.29772

28418.7

Test No. 4: $[\mathrm{Fi} / \mathrm{Te} / \mathrm{Mo} / \mathrm{Tu}][\mathrm{Pa}][\mathrm{Ma}] \mathrm{F}_{\mathrm{GT} / \mathrm{LG}}=37.5$

Among groups

Among locations

11033.5

59.63854

263.6

0.64181

within groups

Among individuals

8667

0.96456

8454.5

38.75509

Within individuals

28418.7

Total

4574.8

6722.3

$\mathrm{F}_{\mathrm{GT} / \mathrm{LG}}=0.0$

Among groups

Among locations

within groups

Among individuals

within locations

Within individuals

Total

8667

0.69617

43.46737

1.35594

8454.5

28418.7

Test No. 6: [Fi][Te/Mo/Tu][Pa][M

Among groups

Among locations

within groups

Among individuals

within locations

Within individuals

Total
11265.6

31.6

8667

8454.5

28418.7
54.48051

$\mathrm{F}_{\mathrm{GT} / \mathrm{G}}=90.6$

52.57038

$-0.27524$

1.15847

46.54638
$\mathrm{F}_{\mathrm{IT}}=0.45451 * * *$

$\mathrm{F}_{\mathrm{GT}}=0.41196^{\mathrm{ns}}$

$\mathrm{F}_{\mathrm{LG}}=0.37482 * * *$

$\mathrm{F}_{\mathrm{IL}}=0.02428^{\mathrm{ns}}$

$\mathrm{F}_{\mathrm{IT}}=0.6413 * * *$

$\mathrm{F}_{\mathrm{ST}}=0.63237 * * *$

$\mathrm{F}_{\mathrm{GT}}=0.18559 *$

$\mathrm{F}_{\mathrm{LG}}=0.37962 * * *$

$\mathrm{F}_{\mathrm{IL}}=0.02428^{\mathrm{ns}}$

$\mathrm{F}_{\mathrm{IT}}=0.50702 * * *$

$\mathrm{F}_{\mathrm{ST}}=0.49475 * * *$

$\mathrm{F}_{\mathrm{GT}}=0.59639 * * *$

$\mathrm{F}_{\mathrm{LG}}=0.0159 * * *$

$\mathrm{F}_{\mathrm{IL}}=0.02428^{\mathrm{ns}}$

$\mathrm{F}_{\mathrm{IT}}=0.61245^{* * *}$

$\mathrm{F}_{\mathrm{ST}}=0.6028 * * *$

$\mathrm{F}_{\mathrm{GT}}=0.00696^{\mathrm{ns}}$

$\mathrm{F}_{\mathrm{LG}}=0.43772 * * *$

$\mathrm{F}_{\mathrm{IL}}=0.02428^{\mathrm{ns}}$

$\mathrm{F}_{\mathrm{IT}}=0.45519 * * *$

$\mathrm{F}_{\mathrm{ST}}=0.44164 * * *$

$\mathrm{F}_{\mathrm{GT}}=0.5257 * * *$

$\mathrm{F}_{\mathrm{LG}}=-0.0058^{\mathrm{ns}}$

$\mathrm{F}_{\mathrm{IL}}=0.02428^{\mathrm{ns}}$

$\mathrm{F}_{\mathrm{IT}}=0.53454 * * *$

$\mathrm{F}_{\mathrm{ST}}=0.52295 * * *$ 
Table 5.3 Pairwise $\mathrm{R}_{\mathrm{ST}}$. Names with numbers indicate the specific sample sites. Red font: significant values after sequential Bonferroni correction (p<0.05). Insert: 2sited $t$-test evaluating the strength and significance of the breaks found. The t-test was used to compare the within groups variation to the between groups variation; groups are coded as square brackets. ${ }^{* * *}, \mathrm{p}<0.0001$. Fight, Fighting Bay; Tera, Cape Terawhiti; Moa, Moa Point; Tura, Turakirae Head; Pall, Cape Palliser; Mata, Mataikona.

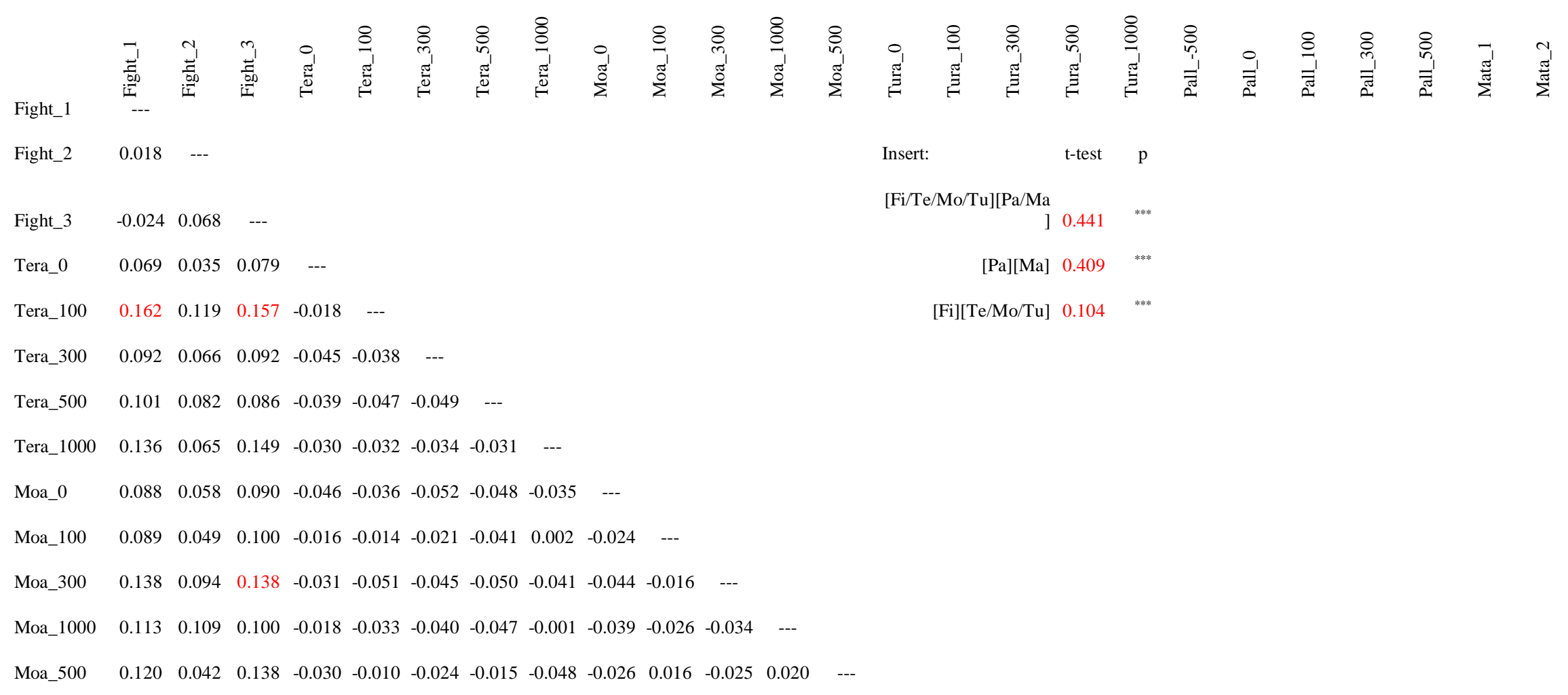




\section{Table 5.3 continued}

$\begin{array}{lllllllllllllll}\text { Tura_0 } & 0.083 & 0.083 & 0.074 & -0.028 & -0.028 & -0.045 & -0.047 & -0.009 & -0.044 & -0.020 & -0.033 & -0.049 & 0.005 & ---\end{array}$

$\begin{array}{llllllllllllllll}\text { Tura_100 } & 0.164 & 0.100 & 0.164 & 0.007 & -0.031 & -0.009 & -0.032 & -0.023 & -0.010 & -0.021 & -0.030 & 0.000 & -0.004 & 0.004 & ---\end{array}$

$\begin{array}{llllllllllllllllllllllll}\text { Tura_300 } & 0.182 & 0.112 & 0.190 & 0.015 & -0.033 & -0.008 & -0.036 & -0.021 & -0.008 & -0.009 & -0.030 & -0.006 & 0.000 & 0.000 & -0.049 & ---\end{array}$

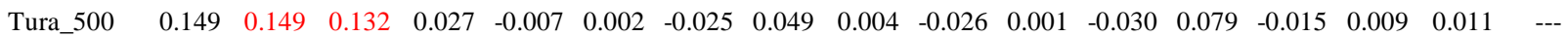

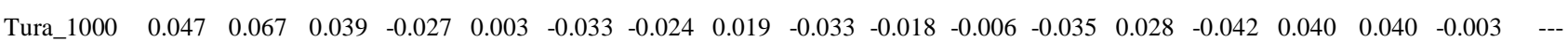

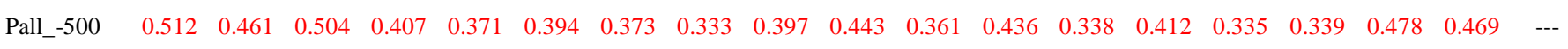

$\begin{array}{lllllllllllllllllllll}\text { Pall_0 } & 0.524 & 0.468 & 0.518 & 0.419 & 0.378 & 0.404 & 0.381 & 0.341 & 0.406 & 0.447 & 0.369 & 0.443 & 0.348 & 0.420 & 0.338 & 0.336 & 0.482 & 0.479 & -0.043 & ---\end{array}$

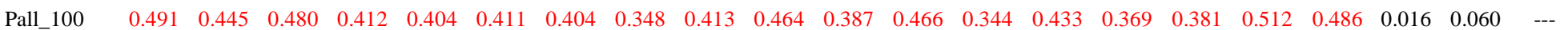

$\begin{array}{lllllllllllllllllllllll}\text { Pall_300 } & 0.485 & 0.437 & 0.473 & 0.393 & 0.378 & 0.389 & 0.381 & 0.325 & 0.392 & 0.445 & 0.362 & 0.444 & 0.323 & 0.412 & 0.344 & 0.356 & 0.491 & 0.468 & -0.004 & 0.038 & -0.048 & -3\end{array}$

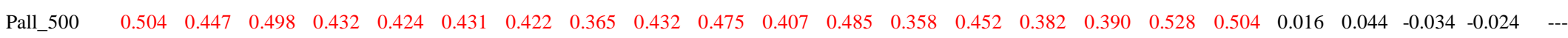

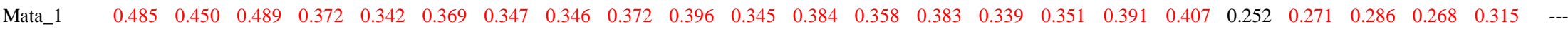

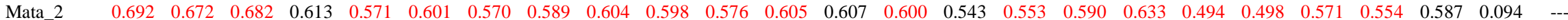


Table S 5.1 Estimated null allele frequencies for all loci in a population using Brookfield 1 and Bonferroni corrections. Null alleles are evident in Fighting Bay,

Turakirae Head, and Mataikona, however, no evidence for null alleles was found in GWG or CSC. Bottom row shows the number (in brackets) of homozygotes to be corrected $\left(\mathrm{H}_{\mathrm{C}}\right)$. *, indicates significant null allele frequencies. Fight, Fighting Bay, Tera, Cape Terawhiti, Moa, Moa Point, Tura, Turakirae Head, Pall, Cape Palliser,

Mata, Mataikona, GWG, Greater Wellington Group (Cape Terawhiti, Moa Point, and Turakirae Head), CSC, Cook Strait Cluster (Fighting Bay and Greater Wellington Group).

\begin{tabular}{lllllllll} 
Locus & Fight & Tera & Moa & Tura & Pall & Mata & GWG & CSC \\
\hline 02A & 0.0000 & -0.0006 & -0.0002 & -0.0056 & -0.0076 & 0.0246 & -0.0013 & -0.0008 \\
09B & $0.0691^{*}$ & -0.0280 & 0.0142 & $0.0613^{*}$ & 0.0070 & -0.0328 & 0.0158 & 0.0329 \\
25C & -0.0069 & 0.0270 & 0.0113 & 0.0129 & -0.0155 & 0.0142 & 0.0188 & 0.0148 \\
33D & 0.0016 & -0.0202 & -0.0129 & 0.0263 & -0.0407 & -0.0460 & -0.0008 & 0.0263 \\
57B & -0.0713 & -0.0190 & -0.0219 & 0.0163 & 0.0626 & $0.1136^{*}$ & -0.0012 & -0.0013 \\
\hline $\mathrm{H}_{\mathrm{C}}$ & $231(4)$ & & & $225(2)$ & & $335(1)$ & &
\end{tabular}


Table S 5.2 Linkage disequilibrium test conducted against 1,000 permutations in ARLEQUIN. *, $\mathrm{p}<0.05$ (after sequential Bonferroni correction).

\begin{tabular}{|c|c|c|c|c|c|}
\hline Locus & $02 \mathrm{~A}$ & 09B & $25 \mathrm{C}$ & $33 \mathrm{D}$ & $57 \mathrm{~B}$ \\
\hline \multicolumn{6}{|c|}{ Fighting Bay } \\
\hline $02 \mathrm{~A}$ & & & & & \\
\hline 09B & 1.000 & & & & \\
\hline $25 \mathrm{C}$ & 1.000 & 0.082 & & & \\
\hline $33 \mathrm{D}$ & 1.000 & 0.807 & 0.383 & & \\
\hline 57B & 1.000 & 0.464 & 0.728 & 0.521 & \\
\hline \multicolumn{6}{|c|}{ Cape Terawhiti } \\
\hline 09B & 0.042 & & & & \\
\hline $25 \mathrm{C}$ & $0.000 *$ & 0.037 & & & \\
\hline 33D & 0.005 & 0.023 & 0.002 & & \\
\hline $57 \mathrm{~B}$ & 0.680 & 0.566 & 0.377 & 0.097 & \\
\hline \multicolumn{6}{|c|}{ Moa Point } \\
\hline 09B & 0.140 & & & & \\
\hline $25 \mathrm{C}$ & 0.096 & 0.702 & & & \\
\hline $33 \mathrm{D}$ & 0.801 & 0.142 & 0.104 & & \\
\hline 57B & 0.441 & 0.344 & 0.774 & 0.909 & \\
\hline \multicolumn{6}{|c|}{$\begin{array}{l}\text { Turakirae Head } \\
02 \mathrm{~A}\end{array}$} \\
\hline 09B & 0.225 & & & & \\
\hline $25 \mathrm{C}$ & 0.106 & 0.367 & & & \\
\hline $33 \mathrm{D}$ & 0.598 & 0.454 & 0.924 & & \\
\hline 57B & 1.000 & 0.820 & 0.061 & 0.327 & \\
\hline \multicolumn{6}{|c|}{ Cape Palliser } \\
\hline 09B & 0.026 & & & & \\
\hline $25 \mathrm{C}$ & 0.587 & 0.416 & & & \\
\hline $33 \mathrm{D}$ & 0.718 & 0.558 & 0.612 & & \\
\hline $57 \mathrm{~B}$ & 0.945 & 0.003 & 0.346 & 0.049 & \\
\hline \multicolumn{6}{|c|}{ Mataikona } \\
\hline 09B & 0.574 & & & & \\
\hline $25 \mathrm{C}$ & 0.023 & 0.548 & & & \\
\hline $33 \mathrm{D}$ & 0.346 & 0.033 & 0.154 & & \\
\hline 57B & 0.388 & 0.864 & 0.072 & 0.446 & \\
\hline
\end{tabular}


Table S 5.3 Allele frequencies and private alleles (red) for all populations by locus. $\mathrm{N}_{\mathrm{A}}$, number of alleles; $\mathrm{N}_{\mathrm{PA}}$, number of private alleles; Fight, Fighting Bay; Tera, Cape Terawhiti, Moa, Moa Point; Tura, Turakirae Head; Pall, Cape Palliser; Mata, Mataikona.

\begin{tabular}{|c|c|c|c|c|c|c|c|c|}
\hline Locus & $\begin{array}{l}\mathbf{N}_{\mathbf{A}} \\
\mathbf{N}_{\mathbf{P A}}\end{array}$ & $\begin{array}{l}\mathbf{6 8} \\
30 \\
\text { Alleles } \\
\end{array}$ & $\begin{array}{l}23 \\
2 \\
\text { Fight } \\
\end{array}$ & $\begin{array}{l}27 \\
0 \\
\text { Tera } \\
\end{array}$ & $\begin{array}{l}28 \\
2 \\
\text { Moa } \\
\end{array}$ & $\begin{array}{l}32 \\
\mathbf{3} \\
\text { Tura } \\
\end{array}$ & $\begin{array}{l}36 \\
11 \\
\text { Pall } \\
\end{array}$ & $\begin{array}{l}34 \\
12 \\
\text { Mata } \\
\end{array}$ \\
\hline 02A & $\begin{array}{l}\mathbf{N}_{\mathbf{A}} \\
\mathbf{N}_{\mathbf{P A}}\end{array}$ & $\begin{array}{l}\mathbf{7} \\
\mathbf{3} \\
217 \\
229 \\
235 \\
238 \\
241 \\
250 \\
256 \\
\end{array}$ & 100.00 & $\begin{array}{l}97.96 \\
1.02 \\
1.02\end{array}$ & $\begin{array}{l}\mathbf{2} \\
\mathbf{0} \\
1.00 \\
\\
99.00\end{array}$ & $\begin{array}{l}\mathbf{3} \\
\mathbf{1} \\
\\
5.00 \\
1.00 \\
94.00\end{array}$ & $\begin{array}{l}\mathbf{3} \\
\mathbf{1} \\
6.00 \\
\\
93.00 \\
1.00\end{array}$ & $\begin{array}{l}15.79 \\
\\
78.95 \\
5.26 \\
\end{array}$ \\
\hline 09B & $\begin{array}{l}\mathbf{N}_{\mathbf{A}} \\
\mathbf{N}_{\mathbf{P A}}\end{array}$ & $\begin{array}{l}\mathbf{6} \\
\mathbf{2} \\
223 \\
224 \\
225 \\
230 \\
231 \\
232 \\
\end{array}$ & $\begin{array}{l}\mathbf{4} \\
\mathbf{1} \\
2.56 \\
17.95 \\
76.92 \\
2.56 \\
\end{array}$ & $\begin{array}{l}\mathbf{3} \\
\mathbf{0} \\
1.00 \\
37.00 \\
62.00\end{array}$ & $\begin{array}{l}36.00 \\
64.00\end{array}$ & $\begin{array}{l}\mathbf{5} \\
\mathbf{1} \\
2.00 \\
2.00 \\
32.00 \\
2.00 \\
62.00\end{array}$ & $\begin{array}{l}\mathbf{3} \\
\mathbf{0} \\
4.00 \\
86.00 \\
10.00\end{array}$ & $\begin{array}{l}\mathbf{2} \\
\mathbf{0} \\
14.29 \\
85.71\end{array}$ \\
\hline $25 \mathrm{C}$ & $\begin{array}{l}\mathbf{N}_{\mathbf{A}} \\
\mathbf{N}_{\mathbf{P A}}\end{array}$ & $\begin{array}{l}\mathbf{9} \\
\mathbf{3} \\
331 \\
340 \\
343 \\
346 \\
349 \\
352 \\
358 \\
379 \\
397\end{array}$ & $\begin{array}{l}92.31 \\
1.28 \\
\\
1.28 \\
1.28\end{array}$ & $\begin{array}{l}92.86 \\
7.14\end{array}$ & $\begin{array}{l}\mathbf{4} \\
\mathbf{1} \\
3.00 \\
1.00 \\
87.00 \\
9.00\end{array}$ & $\begin{array}{l}82.65 \\
10.20 \\
1.02\end{array}$ & $\begin{array}{l}\mathbf{5} \\
\mathbf{1} \\
2.00 \\
\\
6.00 \\
30.00 \\
21.00 \\
41.00\end{array}$ & $\begin{array}{l}37.50 \\
35.00 \\
25.00 \\
\\
2.50 \\
\end{array}$ \\
\hline
\end{tabular}


Table S 5.3 Continue

\begin{tabular}{|c|c|c|c|c|c|c|c|c|}
\hline \multicolumn{2}{|c|}{ Locus } & Alleles & Fight & Tera & Moa & Tura & Pall & Mata \\
\hline \multirow[t]{33}{*}{ 33D } & $\mathbf{N}_{\mathbf{A}}$ & 31 & 7 & 10 & 11 & 10 & 16 & 15 \\
\hline & $\mathbf{N}_{\mathbf{P A}}$ & 17 & $\mathbf{0}$ & $\mathbf{0}$ & 0 & 1 & 9 & 7 \\
\hline & & 349 & & & & 1.02 & & \\
\hline & & 352 & & & & & & 2.78 \\
\hline & & 355 & & & & & & 13.89 \\
\hline & & 358 & & & & & & 11.11 \\
\hline & & 361 & & & & & & 13.89 \\
\hline & & 364 & & & & & & 5.56 \\
\hline & & 367 & & & & & & 2.78 \\
\hline & & 370 & & & & & & 5.56 \\
\hline & & 388 & & 3.06 & 1.06 & 2.04 & & \\
\hline & & 391 & 40.00 & 25.51 & 28.72 & 28.57 & 5.21 & \\
\hline & & 394 & 2.86 & & 4.26 & 8.16 & & \\
\hline & & 397 & & 2.04 & 1.06 & 1.02 & & 8.33 \\
\hline & & 400 & & 2.04 & 2.13 & & & 2.78 \\
\hline & & 403 & & 14.29 & 13.83 & 11.22 & 2.08 & \\
\hline & & 406 & 1.43 & 34.69 & 30.85 & 32.65 & & \\
\hline & & 409 & & 5.10 & 1.06 & 3.06 & & 5.56 \\
\hline & & 412 & 51.43 & 9.18 & 11.70 & 9.18 & & 2.78 \\
\hline & & 415 & 1.43 & 3.06 & 3.19 & 3.06 & 2.08 & 8.33 \\
\hline & & 418 & 1.43 & 1.02 & 2.13 & & 3.13 & 8.33 \\
\hline & & 421 & & & & & 3.13 & \\
\hline & & 424 & & & & & 44.79 & \\
\hline & & 427 & & & & & 2.08 & 2.78 \\
\hline & & 430 & 1.43 & & & & 2.08 & \\
\hline & & 433 & & & & & 2.08 & \\
\hline & & 436 & & & & & 21.88 & 5.56 \\
\hline & & 439 & & & & & 4.17 & \\
\hline & & 442 & & & & & 1.04 & \\
\hline & & 463 & & & & & 1.04 & \\
\hline & & 475 & & & & & 1.04 & \\
\hline & & 478 & & & & & 3.13 & \\
\hline & & 481 & & & & & 1.04 & \\
\hline \multirow[t]{15}{*}{ 57B } & $\mathbf{N}_{\mathbf{A}}$ & 13 & 4 & 7 & 7 & 8 & 7 & 8 \\
\hline & $\mathbf{N}_{\mathbf{P A}}$ & 5 & $\mathbf{0}$ & $\mathbf{0}$ & 1 & $\mathbf{0}$ & $\mathbf{0}$ & 4 \\
\hline & & 281 & & & & & & 10.00 \\
\hline & & 293 & & & & 1.00 & 1.00 & 7.50 \\
\hline & & 296 & 30.77 & 3.00 & 2.00 & 4.00 & 43.00 & 20.00 \\
\hline & & 299 & 5.13 & 4.00 & 4.00 & 3.00 & 8.00 & \\
\hline & & 302 & 62.82 & 64.00 & 69.00 & 53.00 & 22.00 & \\
\hline & & 305 & 1.28 & 2.00 & & 2.00 & & \\
\hline & & 308 & & 6.00 & 4.00 & 3.00 & 2.00 & 12.50 \\
\hline & & 311 & & 18.00 & 18.00 & 33.00 & 23.00 & 5.00 \\
\hline & & 314 & & 3.00 & 1.00 & 1.00 & 1.00 & \\
\hline & & 317 & & & 2.00 & & & \\
\hline & & 332 & & & & & & 12.50 \\
\hline & & 335 & & & & & & 30.00 \\
\hline & & 338 & & & & & & 2.50 \\
\hline
\end{tabular}


Table S 5.4 Second series of AMOVA tests exploring variation within clusters and groups.

Groupings are given in brackets. A) The best grouping within the Cook Strait Cluster was found with $[\mathrm{Fi}][\mathrm{Te} / \mathrm{Mo} / \mathrm{Tu}]$ (test No. 5; $\left.\mathrm{F}_{\mathrm{CT} / \mathrm{SC}}=24.7\right)$. B) No significant variation was found within Grater Wellington group. C) $\mathrm{F}_{\mathrm{ST}}$ between Cape Palliser and Mataikona is significant but $\mathrm{F}_{\mathrm{IS}}$ is not indicating differentiation between Cape Palliser and Mataikona with no subsequent structure in either of these groups. Fi, Fighting Bay; Te, Cape Terawhiti; Mo, Moa Point; Tu, Turakirae Head; SS, Sum of squares; *, $\mathrm{p}<0.05 ; * *, \mathrm{p}<0.001 ; * * *, \mathrm{p}<0.0001$; ${ }^{\text {ns }}$, not significant.

\begin{tabular}{|c|c|c|c|}
\hline & SS & $\%$ variation & Fixation indices \\
\hline \multicolumn{4}{|c|}{ A) within Cook Strait Cluster } \\
\hline \multicolumn{4}{|c|}{ Test No. $1:[\mathrm{Fi} / \mathrm{Te} / \mathrm{Mo} / \mathrm{Tu}]$} \\
\hline Among locations & 263.6 & 3.20427 & $\mathrm{~F}_{\mathrm{LT}}=0.03204 * *$ \\
\hline $\begin{array}{l}\text { Among individuals } \\
\text { within locations }\end{array}$ & 4004.8 & 4.25371 & $\mathrm{~F}_{\mathrm{IL}}=0.04395^{\mathrm{ns}}$ \\
\hline Within individuals & 3741.5 & 92.54201 & $\mathrm{~F}_{\mathrm{IT}}=0.07458^{\mathrm{ns}}$ \\
\hline Total & 8009.9 & & \\
\hline \multicolumn{2}{|c|}{ Test No. 2: [Fi/Te][Mo/Tu] } & $\mathrm{F}_{\mathrm{GT} / \mathrm{LG}}=0.1$ & \\
\hline Among groups & 93.2 & 0.19881 & $\mathrm{~F}_{\mathrm{GT}}=0.00199^{\mathrm{ns}}$ \\
\hline $\begin{array}{l}\text { Among locations within } \\
\text { groups }\end{array}$ & 170.4 & 3.06932 & $\mathrm{~F}_{\mathrm{LG}}=0.03075 *$ \\
\hline $\begin{array}{l}\text { Among individuals } \\
\text { within locations }\end{array}$ & 4004.8 & 4.25091 & $\mathrm{~F}_{\mathrm{IL}}=0.04395^{\mathrm{ns}}$ \\
\hline Within individuals & 3741.5 & 92.48096 & $\mathrm{~F}_{\mathrm{IT}}=0.07519 *$ \\
\hline Total & 8009.9 & & $\mathrm{~F}_{\mathrm{ST}}=0.03268 * *$ \\
\hline \multicolumn{2}{|c|}{ Test No. 3: [Fi/Tu][Te/Mo] } & $\mathrm{F}_{\mathrm{GT} / \mathrm{LG}}=0.3$ & \\
\hline Among groups & 53.8 & -1.29989 & $\mathrm{~F}_{\mathrm{GT}}=-0.01300^{\mathrm{ns}}$ \\
\hline $\begin{array}{l}\text { Among locations within } \\
\text { groups }\end{array}$ & 209.8 & 4.13101 & $\mathrm{~F}_{\mathrm{LG}}=0.04078 * * *$ \\
\hline Within locations & 7746.3 & 97.16888 & \\
\hline Total & 8009.9 & & $\mathrm{~F}_{\mathrm{ST}}=0.02831 * * *$ \\
\hline \multicolumn{2}{|c|}{ Test No. 4: [Fi/Mo][Te/Tu] } & $\mathrm{F}_{\mathrm{GT} / \mathrm{LG}}=0.0$ & \\
\hline Among groups & 89.5 & 0.04245 & $\mathrm{~F}_{\mathrm{GT}}=0.00042^{\mathrm{ns}}$ \\
\hline $\begin{array}{l}\text { Among locations within } \\
\text { groups }\end{array}$ & 174.1 & 3.17557 & $\mathrm{~F}_{\mathrm{LG}}=0.03177 *$ \\
\hline $\begin{array}{l}\text { Among individuals } \\
\text { within locations }\end{array}$ & 4004.8 & 4.25311 & $\mathrm{~F}_{\mathrm{IL}}=0.04395^{\mathrm{ns}}$ \\
\hline Within individuals & 3741.5 & 92.52887 & $\mathrm{~F}_{\mathrm{IT}}=0.07471^{\mathrm{ns}}$ \\
\hline Total & 8009.9 & & $\mathrm{~F}_{\mathrm{ST}}=0.03218 * *$ \\
\hline \multicolumn{2}{|c|}{ Test No. 5: [Fi][Te/Mo/Tu] } & $\mathrm{F}_{\mathrm{GT} / \mathrm{LG}}=24.7$ & \\
\hline Among groups & 232.1 & 7.6603 & $\mathrm{~F}_{\mathrm{GT}}=0.07660 *$ \\
\hline $\begin{array}{l}\text { Among locations within } \\
\text { groups }\end{array}$ & 31.6 & -0.27795 & $\mathrm{~F}_{\mathrm{LG}}=-0.00310^{\mathrm{ns}}$ \\
\hline $\begin{array}{l}\text { Among individuals } \\
\text { within locations }\end{array}$ & 4004.8 & 4.07011 & $\mathrm{~F}_{\mathrm{IL}}=0.04395^{\mathrm{ns}}$ \\
\hline Within individuals & 3741.5 & 88.54754 & $\mathrm{~F}_{\mathrm{IT}}=0.11452^{\mathrm{ns}}$ \\
\hline Total & 8009.9 & & $\mathrm{~F}_{\mathrm{ST}}=0.07382 * * *$ \\
\hline
\end{tabular}


Table S 5.4 Continue

\begin{tabular}{|c|c|c|c|}
\hline & $\mathrm{SS}$ & $\%$ variation & Fixation indices \\
\hline \multicolumn{2}{|c|}{ Test No. 6: [Mo][Fi/Te/Tu] } & \multicolumn{2}{|l|}{$\mathrm{F}_{\mathrm{GT} / \mathrm{LG}}=0.8$} \\
\hline Among groups & 12.3 & -3.85211 & $\mathrm{~F}_{\mathrm{GT}}=-0.03852^{\mathrm{ns}}$ \\
\hline $\begin{array}{l}\text { Among locations within } \\
\text { groups }\end{array}$ & 251.3 & 5.26677 & $\mathrm{~F}_{\mathrm{LG}}=0.05071 * * *$ \\
\hline $\begin{array}{l}\text { Among individuals } \\
\text { within locations }\end{array}$ & 4004.8 & 4.33236 & $\mathrm{~F}_{\mathrm{IL}}=0.04395^{\mathrm{ns}}$ \\
\hline Within individuals & 3741.5 & 94.25298 & $\mathrm{~F}_{\mathrm{IT}}=0.05747^{\mathrm{ns}}$ \\
\hline Total & 8009.9 & & $\mathrm{~F}_{\mathrm{ST}}=0.01415 * * *$ \\
\hline \multicolumn{2}{|c|}{ Test No. 7: [Tu][Fi/Te/Mo] } & \multicolumn{2}{|l|}{$\mathrm{F}_{\mathrm{GT} / \mathrm{LG}}=0.3$} \\
\hline Among groups & 69.5 & -0.99277 & $\mathrm{~F}_{\mathrm{GT}}=-0.00993^{\mathrm{ns}}$ \\
\hline $\begin{array}{l}\text { Among locations within } \\
\text { groups }\end{array}$ & 194.1 & 3.72883 & $\mathrm{~F}_{\mathrm{LG}}=0.03692 * * *$ \\
\hline $\begin{array}{l}\text { Among individuals } \\
\text { within locations }\end{array}$ & 4004.8 & 4.27429 & $\mathrm{~F}_{\mathrm{IL}}=0.04395^{\mathrm{ns}}$ \\
\hline Within individuals & 3741.5 & 92.98965 & $\mathrm{~F}_{\mathrm{IT}}=0.07010^{\mathrm{ns}}$ \\
\hline Total & 8009.9 & & $\mathrm{~F}_{\mathrm{ST}}=0.02736 * * *$ \\
\hline \multicolumn{2}{|c|}{ Test No. 8: [Te][Fi/Mo/Tu] } & \multicolumn{2}{|l|}{$\mathrm{F}_{\mathrm{GT} / \mathrm{LG}}=0.7$} \\
\hline Among groups & 26.1 & -3.16586 & $\mathrm{~F}_{\mathrm{GT}}=-0.03166^{\mathrm{ns}}$ \\
\hline $\begin{array}{l}\text { Among locations within } \\
\text { groups }\end{array}$ & 237.5 & 4.9083 & $\mathrm{~F}_{\mathrm{LG}}=0.04758 * *$ \\
\hline $\begin{array}{l}\text { Among individuals } \\
\text { within locations }\end{array}$ & 4004.8 & 4.31796 & $\mathrm{~F}_{\mathrm{IL}}=0.04395^{\mathrm{ns}}$ \\
\hline Within individuals & 3741.5 & 93.93961 & $\mathrm{~F}_{\mathrm{IT}}=0.06060 *$ \\
\hline Total & 8009.9 & & $\mathrm{~F}_{\mathrm{ST}}=0.01742 * * *$ \\
\hline \multicolumn{2}{|c|}{ Test No. 9: [Fi/Mo][Te][Tu] } & \multicolumn{2}{|l|}{$\mathrm{F}_{\mathrm{GT} / \mathrm{LG}}=0.6$} \\
\hline Among groups & 117.7 & -3.85164 & $\mathrm{~F}_{\mathrm{GT}}=-0.03852^{\mathrm{ns}}$ \\
\hline $\begin{array}{l}\text { Among locations within } \\
\text { groups }\end{array}$ & 145.9 & 6.51089 & $\mathrm{~F}_{\mathrm{LG}}=0.06269 * *$ \\
\hline $\begin{array}{l}\text { Among individuals } \\
\text { within locations }\end{array}$ & 4004.8 & 4.27767 & $\mathrm{~F}_{\mathrm{IL}}=0.04395^{\mathrm{ns}}$ \\
\hline Within individuals & 3741.5 & 93.06308 & $\mathrm{~F}_{\mathrm{IT}}=0.06937^{\mathrm{ns}}$ \\
\hline Total & 8009.9 & & $\mathrm{~F}_{\mathrm{ST}}=0.02659 * * *$ \\
\hline \multicolumn{4}{|c|}{ B) within Greater Wellington Group } \\
\hline Among locations & 31.6 & -0.24654 & $F_{L T}=-0.00247^{n s}$ \\
\hline $\begin{array}{l}\text { Among individuals } \\
\text { within locations }\end{array}$ & 3006.2 & 3.41366 & $\mathrm{~F}_{\mathrm{IL}}=0.03405^{\mathrm{ns}}$ \\
\hline Within individuals & 2863.5 & 96.83288 & $\mathrm{~F}_{\mathrm{IT}}=0.03167^{\mathrm{ns}}$ \\
\hline Total & 5901.3 & & \\
\hline \multicolumn{4}{|c|}{ C) within Wairarapa Cluster } \\
\hline Among locations & 6690.8 & 63.94669 & $\mathrm{~F}_{\mathrm{LT}}=0.63947 * * *$ \\
\hline $\begin{array}{l}\text { Among individuals } \\
\text { within locations }\end{array}$ & 4662.3 & 0.38164 & $\mathrm{~F}_{\mathrm{IL}}=0.01059^{\mathrm{ns}}$ \\
\hline Within individuals & 4713 & 35.67166 & $\mathrm{~F}_{\mathrm{IT}}=0.64328 * * *$ \\
\hline Total & 16066 & & \\
\hline
\end{tabular}


Table S 5.5 Third series of AMOVA tests exploring variation among and within sites. No significant values were found. SS, Sum of squares; ${ }^{\text {ns }}$, not significant.

Fighting Bay

Among sites

Among individuals within sites

Within individuals

Total

Cape Terawhiti

Among sites

Among individuals

within sites

Within individuals

Total

Moa Point

Among sites

Among individuals

within sites

Within individuals

Total

Turakirae Head

Among sites

Among individuals

within sites

Within individuals

Total

Cape Palliser

Among sites

Among individuals

within sites

Within individuals

Total

Matakona

Among sites

Among individuals

within sites

Within individuals

Total
SS

$\begin{array}{lll}1.8 & 0.59841 & \mathrm{~F}_{\mathrm{ST}}=0.00598^{\mathrm{ns}} \\ 26.3 & -0.59415 & \mathrm{~F}_{\mathrm{IS}}=-0.00598^{\mathrm{ns}} \\ 29 & 99.99574 & \mathrm{~F}_{\mathrm{IT}}=0.00004^{\mathrm{ns}} \\ 57.1 & & \end{array}$

$36.5-2.02083 \quad F_{\mathrm{ST}}=-0.02021^{\mathrm{ns}}$

$730.2-10.55157 \quad F_{I S}=-0.10343^{n s}$

$998 \quad 112.5724 \quad F_{\text {IT }}=-0.12572^{\text {ns }}$

1764.7

$\begin{array}{lll}98.3 & 1.27307 & \mathrm{~F}_{\mathrm{ST}}=0.01273^{\mathrm{ns}} \\ 894.2 & 7.67872 & \mathrm{~F}_{\mathrm{IS}}=0.07778^{\mathrm{ns}} \\ 849.5 & 91.04821 & \mathrm{~F}_{\mathrm{IT}}=0.08952^{\mathrm{ns}} \\ 1842 & & \end{array}$

$67.4 \quad-2.13079 \quad \mathrm{~F}_{\mathrm{ST}}=-0.02131^{\mathrm{ns}}$

$1179.7 \quad 12.97205 \quad F_{I S}=0.12701^{n s}$

$1016 \quad 89.15874 \quad F_{\text {IT }}=0.10841^{\text {ns }}$

2263.1

$\begin{array}{lll}314.2 & 4.11525 & \mathrm{~F}_{\mathrm{ST}}=0.04115^{\mathrm{ns}} \\ 1945.3 & 8.3317 & \mathrm{~F}_{\mathrm{IS}}=0.08689^{\mathrm{ns}} \\ 1827 & 87.55305 & \mathrm{~F}_{\mathrm{IT}}=0.12447^{\mathrm{ns}} \\ 4086.5 & & \end{array}$

$93.3-3.48327 \quad \mathrm{~F}_{\mathrm{ST}}=-0.03483^{\mathrm{ns}}$

$2309.5-5.66694 \quad F_{\text {IS }}=-0.05476^{n s}$

$2886 \quad 109.15021 \quad F_{\text {IT }}=-0.09150^{\text {ns }}$ 


\subsection{References}

Alberto, F. 2009. MsatAllele_1.0: An R Package to Visualize the Binning of Microsatellite Alleles. J. Hered. 100:394-97.

Apte, S. \& Gardner, J. P. A. 2002. Population genetic subdivision in the New Zealand greenshell mussel (Perna canaliculus) inferred from single-strand conformation polymorphism analysis of mitochondrial DNA. Mol. Ecol. $11: 1617-28$

Ayers, K. L. \& Waters, J. M. 2005. Marine biogeographic disjunction in central New Zealand. Mar. Biol. 147:1045-52.

Bowman, M. J., Kibblewhite, A. C. \& Ash, D. E. 1980. M2 tidal effects in greater Cook Strait, New-Zealand. Journal of Geophysical Research-Oceans and Atmospheres 85:2728-42.

Bowman, M. J., Kibblewhite, A. C., Murtagh, R. A., Chiswell, S. M. \& Sanderson, B. G. 1983. Circulation and mixing in greater Cook Strait, New-Zealand. Oceanologica Acta 6:383-91.

Brookfield, J. F. Y. 1996. A simple new method for estimating null allele frequency from heterozygote deficiency. Mol. Ecol. 5:453-55.

Coleman, M. A., Gillanders, B. M. \& Connell, S. D. 2009. Dispersal and gene flow in the habitat-forming kelp, Ecklonia radiata: relative degrees of isolation across an east-west coastline. Mar. Freshw. Res. 60:802-09. 
Coyer, J. A., Hoarau, G., Stam, W. T. \& Olsen, J. L. 2004. Geographically specific heteroplasmy of mitochondrial DNA in the seaweed, Fucus serratus (Heterokontophyta : Phaeophyceae, Fucales). Mol. Ecol. 13:1323-26.

Dayton, P. K. 1973. Dispersion, dispersal, and persistence of annual intertidal alga, Postelsia palmaeformis Ruprecht. Ecology 54:433-38.

Evanno, G., Regnaut, S., and Goudet, J. 2005. Detecting the number of clusters of individuals using the software STRUCTURE: a simulation study. Mol. Ecol. $14: 2611-20$.

Excoffier, L., Laval, G. \& Schneider, S. 2005. Arlequin ver. 3.0: An integrated software package for population genetics data analysis. Evolutionary Bioinformatics Online $1: 47-50$.

Faugeron, S., Martinez, E. A., Correa, J. A. \& Billot, C. 2005. Long-term copper mine waste disposal in northern Chile associated with gene flow disruption of the intertidal kelp Lessonia nigrescens. Mar. Ecol. Prog. Ser. 288:129-40.

Forrest, B. M., Brown, S. N., Taylor, M. D., Hurd, C. L. \& Hay, C. H. 2000. The role of natural dispersal mechanisms in the spread of Undaria pinnatifida (Laminariales, Phaeophyceae). Phycologia 39:547-53.

Francis, M. P. 1996. Geographic distribution of marine reef fishes in the New Zealand region. N. Z. J. Mar. Freshw. Res. 30:35-55.

Fraser, C. I., Nikula, R., Spencer, H. G. \& Waters, J. M. 2009a. Kelp genes reveal effects of Sub-Antarctic sea ice during the Last Glacial Maximum. Proc. Natl. Acad. Sci. U. S. A. 106:3249-53. 
Glaubitz, J. C. 2004. CONVERT: A user-friendly program to reformat diploid genotypic data for commonly used population genetic software packages. Mol. Ecol. Notes 4:309-10.

Goldstien, S. J., Schiel, D. R. \& Gemmell, N. J. 2006. Comparative phylogeography of coastal limpets across a marine disjunction in New Zealand. Mol. Ecol. 15:3259-68.

Heath, R. A. 1971. Hydrology and circulation in central and southern Cook Strait, New Zealand. N. Z. J. Mar. Freshw. Res. 5:178-99.

Jakobsson, M. \& Rosenberg, N. A. 2007. CLUMPP: a cluster matching and permutation program for dealing with label switching and multimodality in analysis of population structure. Bioinformatics (Oxf.) 23:1801-06.

Knox, G. A. 1975. The marine benthic ecology and biogeography. In: Kuschel, G. [Ed.] Biogeography and ecology in New Zealand. Dr. W. Junk, The Hague, pp. 353-403.

Kusumo, H. T., Pfister, C. A. \& Wootton, J. T. 2006. Small-scale genetic structure in the sea palm Postelsia palmaeformis Ruprecht (Phaeophyceae). Mar. Biol. 149:731-42.

Lane, C. E. \& Saunders, G. W. 2005. Molecular investigation reveals epi/endophytic extrageneric kelp (Laminariales, Phaeophyceae) gametophytes colonizing Lessoniopsis littoralis thalli. Bot. Mar. 48:426-36. 
Lewis, K. B., Carter, L. \& Davey, F. J. 1994. The opening of Cook Strait: Interglacial tidal scour and aligning basins at a subduction to transform plate edge. Marine Geology 116:293-312.

Macaya, E. C., Boltana, S., Hinojosa, I. A., Macchiavello, J. E., Valdivia, N. A., Vasquez, N. R., Buschmann, A. H., Vasquez, J. A., Vega, J. M. A. \& Thiel, M. 2005. Presence of sporophylls in floating kelp rafts of Macrocystis spp. (Phaeophyceae) along the Chilean Pacific coast. J. Phycol. 41:913-22.

Macaya, E. C. \& Zuccarello, G. C. 2010. DNA barcoding and genetic divergence in the giant kelp Macrocystis (Laminariales). J. Phycol. 46:736-42.

Marsden, I. D. 1991. Kelp-sandhopper interactions on a sand beach in New Zealand. I. Drift composition and distribution. J. Exp. Mar. Biol. Ecol. 152:61-74.

Martinez, E. A., Cardenas, L. \& Pinto, R. 2003. Recovery and genetic diversity of the intertidal kelp Lessonia nigrescens (Phaeophyceae) 20 years after El Nino 1982/83. J. Phycol. 39:504-08.

Ministry of Fisheries and Department of Conservation 2008. Marine Protected Areas: Classification, Protection Standard and Implementation Guidelines. Ministry of Fisheries and Department of Conservation, Wellington, 54 pp.

Moore, L. B. 1949. The marine algal provinces of New Zealand. Transactions of the Royal Society of New Zealand. Section C-Botanical Sciences-Abstracts and Titles 77:187-89.

Nelson, W. A. 1994. Distribution of macroalgae in New Zealand: An archipelago in space and time. Bot. Mar. 37:221-33. 
Norton, T. A. 1992. Dispersal by Macroalgae.pdf. Eur. J. Phycol. 27:293-301.

Pritchard, J. K., Stephens, M., and Donnelly, P. 2000. Inference of population structure using multilocus genotype data. Genet. Breed. 155:945-59.

Reed, D. C. 1990. The effects of variable settlement and early competition on patterns of kelp recruitment. Ecology 71:776-87.

Reed, D. C., Amsler, C. D. \& Ebeling, A. W. 1992. Dispersal in kelps - factors affecting spore swimming and competence. Ecology 73:1577-85.

Reed, D. C., Laur, D. R. \& Ebeling, A. W. 1988. Variation in algal dispersal and recruitment. Ecol. Monogr. 58:321-35.

Reed, D. C., Schroeter, S. C. \& Raimondi, P. T. 2004. Spore supply and habitat availability as sources of recruitment limitation in the giant kelp Macrocystis pyrifera (Phaeophyceae). J. Phycol. 40:275-84.

Ross, P. M., Hogg, I. D., Pilditch, C. A. \& Lundquist, C. J. 2009. Phylogeography of New Zealand's coastal benthos. N. Z. J. Mar. Freshw. Res. 43:1009-27.

Santelices, B. 1990. Patterns of reproduction, dispersal and recruitment in seaweeds. Oceanography and Marine Biology 28:177-276.

Schiel, D. R. \& Foster, M. S. 1986. The structure of subtidal algal stands in temperate waters. Oceanography and Marine Biology Annual Review 24:265307.

Shears, N. T., Smith, F., Babcock, R. C., Duffy, C. A. J. \& Villouta, E. 2008. Evaluation of biogeographic classification schemes for conservation 
planning: Application to New Zealand's coastal marine environment. Conserv. Biol. 22:467-81.

Sliwa, C., Johnson, C. R. \& Hewitt, C. L. 2006. Mesoscale dispersal of the introduced kelp Undaria pinnatifida attached to unstable substrata. Bot. Mar. 49:396-405.

Star, B., Apte, S. \& Gardner, J. P. A. 2003. Genetic structuring among populations of the greenshell mussel Perna canaliculus revealed by analysis of randomly amplified polymorphic DNA. Mar. Ecol. Prog. Ser. 249:171-82.

Taylor, D. I. \& Schiel, D. R. 2003. Wave-related mortality in zygotes of habitatforming algae from different exposures in southern New Zealand: the importance of 'stickability'. J. Exp. Mar. Biol. Ecol. 290:229-45.

Thiel, M. \& Gutow, L. 2005. The ecology of rafting in the marine environment. I. The floating substrata. Oceanography and Marine Biology: An Annual Review 42:181-264.

Thiel, M. \& Gutow, L. 2005. The ecology of rafting in the marine environment. II. The rafting organisms and community. Oceanography and Marine Biology: An Annual Review 43:279-418.

van den Hoek, C. 1987. The possible significance of long-range dispersal for the biogeography of seaweeds. Helgolander Meeresuntersuchungen 41:261-72.

Van Oosterhout, C., Hutchinson, W. F., Wills, D. P. M. \& Shipley, P. 2004. MICRO-CHECKER: software for identifying and correcting genotyping errors in microsatellite data. Mol. Ecol. Notes 4:535-38. 
Walls, K. 1995. The New Zealand experience in developing a marine biogeographic regionalisation. In: Muldoon, J. [Ed.] Towards a marine regionalisation for Australia: proceedings of a workshop. Great Barrier Reef Marine Park Authority, Townsville, Australia, pp. 33-48.

Walls, K. 2006. Nearshore marine classification and inventory - a planning tool to help identify marine protected areas for the nearshore of New Zealand. Department of Conservation, Wellington, 342pp.

Waters, J. M. \& Roy, M. S. 2004. Phylogeography of a high-dispersal New Zealand sea-star: does upwelling block gene-flow? Mol. Ecol. 13:2797-806.

Zuccarello, G. C. \& Lokhorst, G. M. 2005. Molecular phylogeny of the genus Tribonema (Xanthophyceae) using rbcL gene sequence data: monophyly of morphologically simple algal species. Phycologia 44:384-92. 


\section{Chapter 6 Taxonomic confusion in Lessonia from the Falkland Islands}

\subsection{Abstract:}

Since the first descriptions by Bory de Saint-Vincent between 1825 and 1828, the taxonomy and affiliation of Falkland Island Lessonia has confused phycologists. To date seven Lessonia species have been described or assigned to these islands in the centuries following Bory de Saint-Vincent, even though only two to three Falkland Island species have been distinguished by authorities at any time. The reason for this is the altered interpretation of Bory de Saint-Vincent's descriptions of algal material that apparently included samples from two Lessonia species found on Falkland Island. Bory de Saint-Vincent described his material as one species, but twice in successive years using different epithets. Here I clarify the entangled typification and nomenclature of the two Lessonia species found on Falkland Island. 
Keywords: Lessonia flavicans, Lessonia fuscescens, Lessonia frutescens, Lessonia ovata, Lessonia vadosa, Falkland, typification, nomenclature, Lessonia searlesiana.

Protologue [ICBN Appendix VII]. Everything associated with a name at its valid publication, i.e., description or diagnosis, illustrations, references, synonymy, geographical data, citation of specimens, discussion, and comments (McNeill et al. 2006).

Original material [ICBN Art.9.2 Note 2]. For the purposes of this Code, the original material comprises: (a) those specimens and illustrations (both unpublished and published either prior to or together with the protologue) upon which it can be shown that the description or diagnosis validating the name was based; (b) the holotype and those specimens, which, even if not seen by the author of the description or diagnosis validating the name, were indicated as types (syntypes or paratypes) of the name at its valid publication; and (c) the isotypes or isosyntypes of the name irrespective of whether such specimens were seen by either the author of the validating description or diagnosis, or the author of the name (but see also Art. 7.7, second sentence, and 7.8) (McNeill et al. 2006). 


\subsection{Introduction}

Since the first descriptions by Bory de Saint-Vincent between 1825 and 1828 the taxonomy and affiliation of Falkland Island Lessonia has confused phycologists (Tab. 6.1). Five authorities have subsequently described Lessonia species from the Falkland Islands (Bory de Saint-Vincent 1825 \& 1828, Harvey \& Hooker 1847, Skottsberg 1907 \& 1921, Searles 1978, Asensi \& de Reviers 2009). The circumstances that have led to the description of new species and which species they initially recognised will be introduced under the headline of the authority.

\subsubsection{Bory de Saint-Vincent:}

During the French voyage of the 'Coquille' under Duperrey (during 1822-25), considerable attention to Falkland Island plants was paid by Durmont d'Urville, the second in command and botanist. The main purpose of the journey was more scientific than exploratory, thus a second naturalist, Lesson, was also on board (anonymous 1859). After the voyage, the collections of the cryptogams were given to Bory de Saint-Vincent who determined and described the samples. D’Urville, probably working on his career dream to become a commander (Dunmore 2007), urged publication, thus already in 1825 the Flore des Iles Malouines (d'Urville 1825) was separately published in advance of the paper in the Memoires of the Linnean Society of Paris (d'Urville 1826). In the 'Flore des Iles Malouines', d'Urville described Lessonia flavicans in the general narrative part about the voyage but he referred to Bory de Saint-Vincent as the Authority (d'Urville 1825). Only a very brief description of Lessonia flavicans was given (Box A) in the attached species list, for which Bory de Saint-Vincent was responsible (Bory de Saint-Vincent 1825). The note was a pre-digest of the later published volumes about the botany of the 
circumglobal voyage of the Coquille (Bory de Saint-Vincent 1828). No type was specified and no drawings were made. As only a single species was described and as the genus Lessonia was not described, the species description validates the description of the genus (Art. 42 ICBN, as recognised by Searles 1978, McNeill et al. 2006).

Bory de Saint-Vincent (1826) described the genus Lessonia in the ninth volume of the Dictionaire Classique d'Histore Naturelle together with three new Lessonia species; L. fuscescens (Box A), L. nigrescens (reported, by Bory de SaintVincent, from Cape Horn but not from the Falklands), and L. quercifolia (now known as Myriodesma quercifolium (Bory) J.Agardh). No types were specified and no drawings made, but the species was valid published.

Between 1827-1829 the volumes about the botany of the circumglobal voyage of the Coquille were released together with an atlas of 38 plates drawn by Bory de Saint-Vincent. In great detail Bory de Saint-Vincent described the three Lessonia species L. flavicans, L. nigrescens, and L. quercifolia (Bory de SaintVincent 1828). The entry of L. flavicans starts:

“Lessonie brunissante, Lessonia fuscescens (pl. 2, fig. 2, et pl. 3), N. Dict. class. d'hist. nat., tom. IX, p. 322; Lessonia (flavicans), [...]"

followed by the same Latin description Bory de Saint-Vincent used for $L$. flavicans in 1825 and an account in French that started with a direct quote of the complete narrative part made by d'Urville (1825) in Flore des Iles Malouines, where L. flavicans was originally described. Note, however, that Bory de Saint-Vincent put flavicans in brackets and also listed L. fuscescens as a synonym. 


\subsubsection{Joseph Dalton Hooker \& William Henry Harvey}

Two decades later in 1847 another species was described from the Falkland Island as a result of the voyage of H. M. Discovery Ships "Erebus" and "Terror" in the years 1839 and 1843 under the command of Captain Sir James Clark Ross. The botanist and the youngest of the 128 man crew on the ship was J. D. Hooker, who, together with W. H. Harvey, described L. ovata as a new species in Hooker's book, known as 'Flora Antarctica' (Hooker 1847). From the Falklands, Hooker and Harvey recognised three Lessonia species; L. fuscescens (putting L. flavicans in a synonymous status), L. nigrescens [however, no L. nigrescens is found on the Falklands (Searles 1978) and they do not have air-cavities as described and drawn by Hooker (fig. 167-168. C)], and a new species L. ovata (Harvey \& Hooker 1847) (Box A). In 1855 the Atlas of the Flora was printed where Hooker dedicated three plates to Lessonia, illustrating fronds and whole individuals of L. fuscescens (fig. 167-168. A \& fig. 171. D) and L. ovata (fig. 167-168. B \& fig. 171. C) in relationship to Macrocystis. About L. fuscescens they wrote that it is found always far beyond low-water mark and that it has lacunae (air-cells) (fig. 167-168. A1). They did not explain why they accepted L. fuscescens instead of L. flavicans.

\subsubsection{Carl Skottsberg}

For his $\mathrm{PhD}$, Skottsberg worked on the Antarctic and Sub-Antarctic marine algae with a focus on the 'Phaeophyta'. He made extensive collections during the Swedish Antarctic expedition between 1901 and 1903 on Grahams Land (Antarctic Peninsula), South Georgia, Terra del Fuego, and the Falkland Islands. On the Falklands, he recognized L. nigrescens, L. flavicans (while using L. fuscescens and L. ovata as synonyms), and a new species L. frutescens (Box A). However, no $L$. 
nigrescens is found on the Falklands (Searles 1978); furthermore, L. nigrescens does not have lacunae (Schleimraeme) as described and illustrated by Skottsberg (1907) but it is possible that he followed the description made by Hooker (1847), who also recognised L. nigrescens on the Falkland Islands and who depicted them with lacunae (air-cavities) (Scottsberg 1921). Skottsberg's (1907) detailed description of L. nigrescens is identical to the later described L. vadosa, indicating a missidentification. About L. flavicans he stated that Bory de Saint-Vincent (1828) changed the name into L. fuscescens while putting L. flavicans in brackets, however, he recognised L. flavicans as the older name. Skottsberg referred to Hooker \& Harvey (1847 p.459) when he described L. ovata as a species that is smaller (but treelike) then L. flavicans with laminae that are broader at the base with a round stipe. However, he found round stipes together with laminae that are narrow at the base and laminae with a wide base that merge into very flat stipes. His material indicated to him that a roundish, blunt base is characteristic of young individuals, whereas in older algae the base of the laminae becomes progressively narrow and the whole blade becomes longer and narrower. As this supported Hooker and Harvey's speculation that L. ovata might be the younger stage of L. fuscescens, Skottsberg treated L. ovata as a synonym of L.flavicans (L. fuscescens).

Skottsberg (1907) noted that $L$. frutescens differs from $L$. ovata as it is shorter and has more stipes. L. frutescens differs from L. flavicans as in L. flavicans, even in young algae, the stipes are already longer than in L. fuscescens and the blades are narrower and dentate. The holdfast is weaker than in L. flavicans. $L$. frutescens is found in the upper sublitoral and is often fully exposed during ebb tide. 
Numerous mucilage cavities can be found in the blade, however, none were found in haptera or young parts of the stipe.

Skottsberg admitted in his 1921 paper: "Still, it is possible that L. frutescens is nothing but a local form of L. nigrescens". In the same publication he described two new algae, L. nigrescens $f$. montagnei and L. nigrescens $f$. lacunifera. He explains: 'No 'true' L. nigrescens has been found in the Falkland Islands. Still, from reasons given under L. flavicans, I retain the Falkland plant under the old name, adding 'f. lacunifera' for convenience sake." And to the 'true' L. nigrescens he added 'f. montagnei' (Skottsberg 1921).

\subsubsection{Richard B. Searles}

Searles (1978) made an extensive survey of the Lessonia species in Southern Chile and Argentina. Whereas some scientists (e.g., Agardh 1877) already assumed that lacunae might be species specific, Searles (1978) was the first who used this character to distinguish between the two species recognized by him on the Falkland Islands. The species are: L. flavicans (with L. fuscescens, L. ovata, and L. frutescens as synonyms) and the new described Lessonia vadosa. He also excluded any records of L. nigrescens from the Falkland Islands (see Hooker \& Harvey and Skottsberg).

As no holotype was assigned to L. flavicans he assigned a lectotype from Bory de Saint-Vincent's herbarium, which comprises samples made by d'Urville and Lesson, choosing a specimen collected by Lesson on the Falkland Islands (Searles 1978). The specimen had a richly branched holdfast, a single stipe and entire blades that lack lacunae. Why this specimen was chosen is not clear, however it fitted the description of L. ovata, which was placed in a synonymous status. As Skottsberg (1907) had not assigned a holotype to his L. frutescens, Searles also assigned a 
lectotype to this species, recognising the algal specimen depicted in the original description in Skottsberg's herbarium. When he found that the lectotype bears lacunae in the blade, in contrast to Skottsberg's description, he decided to assign $L$. frutescens as a synonymy of $L$. flavicans and described a new species, $L$. vadosa (Searles 1978) (Box A).

Searles (1978) adds to the description that "Plants of this species (fig. 9) are differentiated from L. flavicans by their narrow blades (fig. 3), wider blade base angle relative to the blade width (fig. 4), lacunate cortex and a shallow, subtidal habitat" whereas L. flavicans is found in deeper water.

\subsubsection{Aldo Asensi \& Bruno de Reviers}

The latest attempt to clarify the situation was undertaken by Asensi \& deReviers (2009), who found that Searles has chosen the wrong lectotype for L. flavicans, from material that was actually not eligible. The reason is that Searles (1978) has chosen an individual collected by Lesson, however, Lesson was not mentioned in the first description of Lessonia flavicans (d'Urville 1825), and thus only material collected by d'Urville, who wrote the narrative to the original description, should be treated as original material, from which types can be selected (Asensi \& deReviers 2009). Bory de Saint-Vincent (1825) has not indicated any type location however d'Urville mentioned in the protolog that Lessonia is often found at the coasts of l'ile aux Pingouins [Long Island, Berkeley Sound, East Falkland Island] (d'Urville 1825). Accordingly, Asensi \& de Reviers (2009) chose a new lectotype of L. flavicans collected by d'Urville at l'ile aux Pingouins on the Falkland Island. Among the original material they were able to choose the very same individual that was depicted by Bory de Saint-Vincent in the atlas of the 'voyage autour du monde' (Bory de 
Saint-Vincent 1828). Their microscopic analyses of the blade anatomy revealed lacunae in the new lectotype of L. flavicans, and consequently L. vadosa was regarded as a taxonomic synonym to the new L. flavicans sensu Asensi \& de Reviers. Thus not only the lectotype has changed but also the designation of the species and the species L. flavicans sensu Searles was now nameless. Asensi \& de Reviers (2009) designated an individual among Searles' original material of $L$. flavicans sensu Searles to describe the new species L. searlesiana. What was known as L. flavicans sensu Searles is now L. searlesiana and what was know as L. vadosa is now L. flavicans. No taxonomic synonyms have been listed for either of the new designated species except for L. vadosa as a synonym for L. flavicans.

\subsection{Discussion}

\subsubsection{Species one: L. flavicans}

Bory de Saint-Vincent's (1825) description of L. flavicans is short and from today's perspective both Falkland Islands Lessonia species can be assigned to this description, thus the designation of a type specimen is essential. L. flavicans was validly published (ICBN Art. 32.1, McNeill et al. 2006) as shown by Chamberlain (1965) on the example of Iridaea undulosa. The protologue to the species comprises the narrative part made by d'Urville and the species description made by Bory de Saint-Vincent (ICBN Appendix VII, McNeill et al. 2006). As no holotype was specified and no drawings have been made, the protologue is used to gather information in order to assign a species to the name or the authority to an autonym (e.g., in the narrative d'Urville validated the autonym L. flavicans and assigned it to Bory de Saint-Vincent when he finished with the sentence "C'est cette plante que $M$. Bory de Saint-Vincent a nommee Lessonia flavicans") (McNeill et al. 2006). The 
additional information given by d'Urville (1825) includes information about the possible type locality (“[...] l'ile aux Pingouins”) where Lessonia is very common; but also about the stipe, the blades and the holdfast when he writes, "Its trunk, which is cylindrical, somewhat wooden and often as thick as a thigh, divides into multipledichotomous and compressed branches that always end with spear-like, undulating, smooth and fine dentate fronds. It is seldom longer than 8-10m (quatre ou cinq toises), and I never saw the fronds reaching out of the water. They usually reach only until a few inches (pouces) to the sea surface, where they form relatively dense foliations. The stem sticks to stones or other solid bodies with a fleshy, thick and somewhat thick-bordered disk, which is sometimes divided into three or four parts at its base. Without penetrating the material on which it grows it adheres so strongly that one would break the trunk instead of detaching it..." [Translated from the French original by S. Bourguignon].

In Bory de Saint-Vincent's herbarium both species are found under the name L. fuscescens but the samples given to Bory de Saint-Vincent by Lesson show $L$. flavicans sensu Searles whereas the samples given to Bory de Saint-Vincent by d'Urville show L. flavicans sensu Asensi \& de Reviers (the samples I have seen are PC0062744, PC0062747, PC0062748, PC0062749, PC0062750; preserved at PC). D'Urville's (1825) description in the protologue, especially the characters of the algal height, thickness of the stipe and the morphology of the holdfast, best describes the alga shown in Fig. 1.7 D\&F (Chapter 1) and fig. 167-168 A \& fig. 171 D in Harvey \& Hooker (1847). As this is most likely the same species as shown on the herbarium vouchers made by d'Urville, I will follow the re-typification as proposed by Asensi \& deReviers (2009). Asensi \& deReviers (2009) also argue that Bory de 
Saint-Vincent (1828) might have preferred L. fuscescens as the species epithet as he put flavicans in brackets when he combined the two species into one. However, brackets were used in this series to emphasise species names not the other way around, thus the plea to conserve the name L. fuscescens against L. flavicans (Asensi $\&$ deReviers 2009) is not justified.

An emended species description could be the one used by Searles (1978) for L. vadosa (see diagnosis of L. vadosa in Box A). Note that the alga might become bigger as indicated in Searle's description (see d'Urville 1825 and Fig. 1.7 C\&D). In the original paper referring to L. vadosa Searles (1978) indicated different growth forms: "Plants of the sublittoral fringe appear to be limited in height by the water depth and are short and bushy. These small bushy plants might also occasionally initiate an adventitious erect stipe from the haptera of the holdfast; the basal segment of the stipe might be short and thick. Larger plants from slightly deeper water have a long unbranched lower stipe and a bushy crown (fig. 11). The dichotomies of the branch system in this species are often asymmetric; the larger of a pair of blades divides more frequently and leaves the smaller blade behind on the stipe in a pattern reminiscent of Macrocystis, but not as pronounced. The smaller blade and branch might subsequently break off and the scar is smoothed over by growth of the meristoderm to produce a long, unbranched lower stipe."

A few species have been described for the Falkland Islands and some must be considered as synonyms to this typification, whereas others most likely refer to a second species. The ones to be considered as synonyms to Lessonia flavicans Bory, 1825 are: 
Lessonia vadosa Searles, 1978 (as recognised by Asensi \& deReviers (2009)); and Lessonia nigrescens f. lacunifera Skottsberg, 1921.

Misapplied names: L. nigrescens sensu Hook. fil. \& Harv. 1847; L. nigrescens sensu Skottsberg, 1907.

Descriptions that might refer to a second species are Lessonia fuscescens Bory, 1826; Lessonia ovata J.D. Hooker \& Harvey, 1847; Lessonia frutescens Skottsberg 1907 (partim. lectotype without lacunae (Searles 1978)); Lessonia searlesiana Asensi \& de Reviers, 2009.

\subsubsection{Species two: L. fuscescens [?], L. ovata, (L. frutescens, (L. searlesiana))}

\subsubsection{L. searlesiana}

L. searlesiana was described in 2009 by Asensi \& de Reviers to account for the problem that L. flavicans sensu Searles would be without a name after the new lectotypification of L. flavicans (Asensi \& deReviers 2009). Yet, as not only the lectotype changed but also the concept of L. flavicans every species that was in synonymy with the old meaning would have been available.

\subsubsection{L. frutescens}

No type specimen was assigned to L. frutescens by its authority Skottsberg (1907). On March 15 in 1978 Searles lectotypified L. frutescens using the only specimen available in Skottsbergs collection, and which is identical to the picture (taf.8) in Skottsberg (1907). For the description, Skottsberg (1907) could not use a specimen from his own collection as only pieces of the specimen he had sampled at Berkeley Sound were available and did not yield useful information. This lack was because the 'Antarctic', the ship utilized for the Swedish South Polar expedition, foundered on 
February 12, 1903 and with it its valuable scientific cargo. Skottsberg could only save a packet from the sinking ship that included some algae on herbarium sheets. The biggest part of the Falkland collection, however, was packed and brought to land earlier (Skottsberg 1907 p.1). Thus he used a specimen collected by S. Birger at Port Stanley a year later (Skottsberg 1907 p.78 footnote). Parts of the diagnosis (especially habitat descriptions) do not correspond to the lectotype, which is based on the figure (taf. 8) of the paralogue. In plant nomenclature, figures, drawings, and types have priority to diagnoses and consequently Searles had to move L. frutescens into synonymy with L. flavicans sensu Searles when he found, contrary to the description, no lacunae in the cortex of the blade. The lectotype of L. frutescens corresponds to the concept of L. flavicans sensu Searles (wide blade base angle, width of blade, holdfast structure, and with lacunae) and would have had priority over L. searlesiana. However, the alga Skottsberg wanted to describe was a different one that grows in the intertidal, has lacunae in the blade, and is only found on Falkland (e.g., Fig. 1.7 A).

\subsubsection{L. ovata}

L. ovata was discovered during the English voyage of the ships Erebus and Terror to the Antarctic in the years 1839-1843 and described by J.D. Hooker (who was assistant surgeon and botanist to the expedition) and Harvey in 1847 (Hooker 1847). No type was assigned but Hooker made some nice drawings in an atlas that was released in 1855 (Hooker 1855). In the 1847 publication he referred to the drawings within the atlas in the diagnosis to L. ovata (Tab. CLXVII.-CLXVIII. B; et Tab. CLXXI. C.). Searles (1978) writes that the L. ovata plates CLXVII.-CLXVIII. B and B1 correspond to L. flavicans and that Plate CLXXI could represent either $L$. 
flavicans or L. vadosa. He also wrote that he could not find any type specimen in the herbaria of Kew, the British Museum or Trinity College corresponding to Hooker \& Harvey's description. At Trinity College there are no L. ovata specimens (pers. comm. with Professor John Parnell, Head of the School of Natural Sciences, Trinity College Dublin, Dublin). Kew has given their algae collection on permanent loan to the British Museum (pers. comm. Prof. David J. Mabberley, Keeper of the Herbarium, Library, Art \& Archives, Royal Botanic Gardens, Kew) but their specimens of L. ovata are preserved; two bearing the handwriting of J.D. Hooker stating "Lessonia ovata Fl. Ant. Antarctic Sea J.D.H." (K in BM without number). Both sheets are very similar to the drawing in Hooker's Atlas (Hooker 1855) and are indicated with "Fl. Ant." for Flora Antarctica, the short name of Hooker's book from 1847.

As no types are assigned to L. ovata it is necessary to designate a lectotype (ICBN, Art. 9.9; McNeill et al. 2006). I suggest this should be one of the two herbarium specimens found in BM and the other should be an isolectotype. Both specimens have the appearance of $L$. searlesiana and thus might have priority as being the older name although additional anatomic study might be required. I discovered unpublished drawings attached to a herbarium sheet of a alga determined to be L. ovata and collected by Moseley at Heard Island (BM000937207). These drawings, which are made of $L$. ovata by Hooker (with unknown handwriting stating "drawings of type"), show sections of blade and stipe. Within the blade and stipe, no lacunae are drawn but there is a large area of ruptured cells in the blade section. 


\subsubsection{L. fuscescens}

After Bory de Saint-Vincent described L. flavicans in 1825 he described another species L. fuscescens a year later (Bory de Saint-Vincent 1826) with a different diagnosis. As noted above, both species are found in Bory de Saint-Vincent's herbarium under the epithet L. fuscescens, however, the ones collected by d'Urville (PC0062749, PC0062750) are different to the ones collected by Lesson (PC0062744, PC0062747, PC0062748). In the diagnosis to the new species, Bory de SaintVincent referred to Lesson as the collector and 'Conception du Chili' as the type locality. Thus Bory de Saint-Vincent used a different sample from a different collection (Lesson's collection) when he made the diagnosis to L. fuscescens (as a reminder: d'Urville's collection is believed to be the source for the description of $L$. flavicans and based on the protologue in d'Urville (1825) 'l'ile aux Pingouines' is considered to be the type locality). As far as I know, there is only one sample in Bory de Saint-Vincent's collection labelled as being from Concepción, Chile (PC0062747). At the bottom of the sheet, Bory de Saint-Vincent noted that it was given to him by Lesson. For this reason it is not mandatory to assume that for his description of $L$. fuscescens Bory (1826) 'definitely included the type' of $L$. flavicans, and therefore this name is neither superfluous nor can it be treated as nomen illegitimum (ICBN Art. 52.1, McNeill et al. 2006) as suggested by Searles (1978) and Asensi \& deReviers (2009). That two years later Bory de Saint-Vincent (1828) merged the two species into one with the name L. flavicans is for taxonomic decisions irrelevant as only information known at the time of publication are essential (ICBN Art. 52.1, McNeill et al. 2006). Bory de Saint-Vincent (1826) also writes that d'Urville reported that 'it' [L.fuscescens] is found on the Falkland Islands, where it grows in great quantities at some distance to the shore (see 
introduction to this Chapter for the original text). As L. flavicans (the one d'Urville sampled) is found close to the shore and the second species is found in some distance from the coast (Searles 1978; remember that Searles used the opposite meaning of the epithet) this might indicate that d'Urville was aware of two species at Falkland.

A type has not been assigned so far, thus I suggest to lectotypify (ICBN, Art. 9.9; McNeill et al. 2006) the sample, which is preserved under the number PC0062747 at the 'Museum National d'Histoire Naturelle' in Paris (PC) for reasons given above. However, there are possibly two different species mounted; one with slightly narrower blades on the left and another with broader blades on the right. It has to be carefully examined to determine whether they belong to one or two species. As the collection site of Concepción is out of the species range reported for the Lessonia species also found on the Falklands, it is possible that one or both morphotypes are identical to L. trabeculata. If one or both morphotypes, however, are found to have no lacunae in the cortex it would indicate that the species range of L. ovata has to be extended to Concepción. Montagne (1852) reported L. ovata from Concepción; he also found that L. fuscescens and L. ovata have been mixed by Bory de Saint-Vincent in d'Urville's collection, but he might have confused Lesson's collection with d'Urville's collection as in d'Urville's collection no specimen from Concepción was found. Synonym status for L. ovata, L. frutescens and $L$. searlesiana species to L. fuscescens might be possible but has to be further investigated. 


\subsection{Conclusions}

Nobody has shown so far that the occurrence of lacunae is species specific i.e., correlated with genetic evidence. However, based on morphology two different species were separated by Searles (1978). Blade width and the depth where the alga was collected have been correlated to lacunae (Searles 1978), thus individuals found in greater depth, with broad blades ( $>8 \mathrm{~cm}$ in width), and no lacunae in the blade were referred to L. flavicans sensu Searles. For the reasons explained above they were newly described as L. searlesiana (Asensi \& deReviers 2009). But the Latin diagnosis (see Skottsberg (1907), p.78; and introduction above) and the lectotype (S: A1388; assigned by Searles 19 May 1979) of L. frutescens describe the same species; therefore L. frutescens has priority over L. searlesiana. However, the even earlier described L. ovata (Harvey \& Hooker 1847) has, based on Latin and English description and morphology (blade width), priority over both epithets. A type has to be assigned to L. ovata and I suggest one of the two samples determined as L. ovata and signed by Hooker, which are found in BM.

Even though L. flavicans and L. fuscescens have often been used as synonyms there is no need to believe that they are based on the same type material (as suggested by Searles 1978 and Asensi \& deReviers 2009). Whereas L. flavicans is based on a sample from "l'ile aux Pingouins" in d'Urville's collection (Asensi \& deReviers 2009), L. fuscescens is, according to the protologue (Bory de SaintVincent 1826), based on an individual sampled by Lesson in Concepción, Chile. As no type is assigned so far, I suggested PC0062747 (PC), as it is the only sample known to me that was collected by Lesson at "Concepción au Chili". Based on the 
sample site it is most likely a L. trabeculata-like individual but additional anatomic study is required.

\subsection{Tables}

Box A: Original diagnosis of species found on the Falkland Islands and their English translations (translations of L.flavicans, L. fuscescens, L. ovata, and L. frutescens made by P. Martin; the other translations are given by the authorities):

Lessonia flavicans. Caule sub-arboreo cylindrico, ramis compressis, foliis ovatalinearibus, subdenticulatis, flavicantibus. (Bory de Saint-Vincent $1825, \mathrm{n}^{\circ} 29$ )

Lessonia flavicans. Stipe somewhat treelike cylindrical, branches compressed, blades oval-linear, somewhat denticulated, yellowish.

Lessonia fuscescens, $N$., a tige arborescente, inferieurement simple, se divisant a son extremite en rameaux nombreux, cylindriques, qui a leur tour se fourchent en ramules entrelacees, fort comprimees, noiratres, supportant des frondes lineaires ou ovales-allongees, acuminees inferieurement et superieurement, a bords legerement ou fort obscurement dentes quand ces bords ne sont pas d'une integrite parfaite. Cette espece nous fut d'abord communiquee par Lesson qui l'avait recueillie a la Concepción du Chili et par Durville qui l'a rapportee des iles Malouines, ou elle croit en grande quantite a quelque distance du rivage. Elle sera figuree dans la relation du voyage de la Coquille. (Bory de Saint-Vincent 1828)

Lessonia fuscescens, N., stipe treelike, at the bottom simple, divides at the top into numerous, cylindrical branches, those further divide in to smaller, entangled, very 
compressed, blackish branches, they support linear or oval-elongated fronds that acuminate at the bottom and top, the edges are fine or course dentated if not entirely smooth. This species was first communicated to us by Lesson, who collected the species at Concepción, Chile and by d'Urville, who reported that it is found on the Falkland Islands, where it grows in great quantities at some distance to the shore. It is correlated to the voyage of the Coquille.

Lessonia ovata, Hook. fil. et Harv.; stipite brevi vage dichotome ramoso, ramis brevibus divaricatis, frondis laciniis breviter petiolatis, petiolo in laminam ovatam lineari-ovatamve olivaceo-fuscescentem submembranaceam dilatato. (Tab. CLXVII.CLXVIII. B; et Tab. CLXXI. C.)

Hab. Hermite Island, Cape Horn, and the Falkland Islands, very abundant.

Radix e fibris perplurimis crassis intricatis massam 1-2ped. latam efficientibus. Stipites e radice plurimi (ut in Macrocysti) 4-6 unc. longi, torti v. flexuosi, erassitie pollicis humanae, dichotome fissi, demum solitarii, incrassati, subarborescentes. Laminae pedales, colore et substantia L. fuscescentes, juniores basi obscure sinuatodentatae; adultae integerrimae. (Harvey \& Hooker 1847)

Lessonia ovata, Hook. fil. et Harv.; short stipes, here and there dichotomously branched, branches short and split at a wide angle, fronds shortly after the petiole cleaved, the petiole broadens into an oval or linear-oval, olive-darkish, thin (somewhat membranous) lamina. (Tab. CLXVII.-CLXVIII. B; et Tab. CLXXI. C.) Hab. Hermite Island, Cape Horn, and the Falkland Islands, very abundant. The root is formed from many thick fibres that form an entangled mass $30-60 \mathrm{~cm}$ 
broad. Stipes emerge numerous from the root (like in Macrocystis) they are 4-6 unc. [?] long, twisted or flexuous, erassitie a human thumb, split dichotomously till completely separated, thick, somewhat like a tree. The bases of the blades are of the colour and substance as L. fuscescens, the base in young individuals is weakly sinuated to dentated, but entire in adult algae.

L. frutescens Skottsberg n. sp. - Tab. 8. Inde a basi dichotoma, stipite primario fere nullo; rami breves, crassi, 1,5-4cm longi, \pm complanati. Folia ovato-lanceolata, basi rotundato-angustata, adulta 50-60 cm longa, 10-17 lata, margine integerrima, elastica. Hapterae numerosae, crassae, massam diam. circ. $15 \mathrm{~cm}$ formantes. Color fuscus vel olivacea-fuscus. Cetera ignota. (Skottsberg 1907)

L. frutescens [becoming shrubby] n. sp. Splits dichotomous right at the base, primary stipe almost lacking; branches short, thick, $1.5-4 \mathrm{~cm}$ long, \pm flattened. Blades ovatelanceolate, at the base narrow rounded, adult blades are 50-60 $\mathrm{cm}$ long, $10-17 \mathrm{~cm}$ broad, margines entire, elastic. Haptera numerous, thick, forming a mass of circa $15 \mathrm{~cm}$ in diameter. Colour grey-brown or at least olivaceous-grey-brown. The rest is unknown.

Lessonia vadosa Searles sp.nov. Plantae ad $3 \mathrm{~m}$ altae; una stipes dichotome vel subdichotome ramata, ex systemate hapterorum separatim ramatorum et distinctorum exorta. Rami minores ex furcis veterioribus in plantis magnis deperditi, quarum postea ima stipes inramata videtur. Laminae angustae, 2-6(9) cm latae, (8)12-68(89) cm longae; margines integri vel subdentati. Summa lamina uniformiter 
pigmentifera; cortex laminae et stipitis lacunas sphaericas vel ellipticas habet.

Lessonia vadosa. Plants to $3 \mathrm{~m}$ tall; one dichotomously to subdichotomously branched stipe arising from a system of freely branched, distinct haptera. Lesser branches of older dichotomies lost by large plants, the lower stipe then appearing unbranched. Blades narrow, 2-6(9) cm wide, (8)12-68(89) cm long, margins entire or with small teeth. Surface of blade uniformly pigmented, cortex of blade and stipe with spherical to ellipsoidal lacunae. (Searles 1978)

Lessonia searlesiana Asensi et Reviers, sp. nov.

Diagnosis: Species Lessonia, e meridiei regione quae ultra Oceanum spectat, denso cortice parenchymato instructa, in lamina tamquam in stipite, qua re a Lessonia berteroana differt, cujus cortex filis instructus est, differtque a Lessonia flavicanti lacunis absentibus, quibus lacunis illius speciei propriis, differtque tandem a Lessonia nigrescenti in systemate hapterorum quod stipitem unum gignit pro mole solida, quae nonnullos gignit; lamina angulusque ab ima laminae parte latius patent quam in Lessonia flavicanti et species altius quam Lessonia flavicans crescit.

South-American Lessonia species with a solid parenchymatous cortex of blades and stipe, not filamentous like L. berteroana and lacking the lacunae typical of $L$. flavicans; with only one stem originating from ramified haptera, not numerous ones from a massive holdfast like in L. nigrescens. Wider blades and wider blade base angle, compared to L. flavicans; vertical distribution extending deeper in subtidal than in L. flavicans.

Misapplied name: L. flavicans sensu Searles (1978) British Phycological Journal 13: 
$361-381$.

Holotype: PC0124194 (Figure 13) (Duke University Algal Herbarium 16175 given by R.B. Searles to PC)

Type locality: "Just west of Punta Conway on Isla de los Estados, Argentina"

Collectors: R.B. Searles, G.L. Leister and J.F. Brauner on 4 May 1973.

Etymology: the epithet is in honour of R.B. Searles who first depicted the species. (Asensi \& deReviers 2009) 
Table 6.1 Affiliation of the South American species (L. flavicans, L. ovata, L. nigrescens, and L. trabeculata) to selected authorities and their understanding of the species. L. flavicans has been confused with L. fuscescens, L. nigrescens, L. frutescens, L. nigrescens f. lacunifera, and L. vadosa; whereas, L. ovata has been confused with $L$. fuscescens, L. flavicans, L. frutescens, and L. searlesiana. N, number of species recognised on the Falkland Islands (species recognised on the Falkland Islands have a grey background); the first three letters of the name have been used for species and genera (if not Lessonia) abbreviation; na, not applicable; nm, not mentioned.

\begin{tabular}{|c|c|c|c|c|c|c|}
\hline Reference & $\mathrm{N}$ & $\begin{array}{l}\text { L. flavicans } \\
\text { lacunae }\end{array}$ & $\begin{array}{l}\text { L. ovata } \\
\text { w/o lacunae }\end{array}$ & L. nigrescens & L. trabeculata other & Remarks \\
\hline $\begin{array}{l}\text { Bory de } \\
\text { Saint- } \\
\text { Vincent } \\
1825\end{array}$ & 1 & L. flavicans & & & & $\begin{array}{l}\text { based on d'Urvills collection } \\
\text { Type locality: l'ile aux Pingouins, Falkland } \\
\text { Lectotype: PC } 0062750\end{array}$ \\
\hline $\begin{array}{l}\text { Bory de } \\
\text { Saint- } \\
\text { Vincent } \\
1826\end{array}$ & 1 & $\mathrm{~nm}$ & $\begin{array}{l}\text { L. fuscescens } \\
{[?]}\end{array}$ & L. nigrescens & $\begin{array}{l}\text { L. fuscescens L. quercifolia } \\
\text { [?] }\end{array}$ & $\begin{array}{l}\text { L.fus: based on Lesson's collection; Type } \\
\text { locality: Concepción de Chili; might be } \\
\text { identical to L. trabeculata (collection site), } \\
\text { L. searlesiana (width of blade on right), or L. } \\
\text { flavicans (not likely). No type has been } \\
\text { assigned; thumbnail shows proposed type } \\
\text { (PC0062747). } \\
\text { L.nig: based on Lamouroux collection [he } \\
\text { called it Laminaria ramosissima (Bory 1826) } \\
\text { or ramosa (nom.herb. PC0062752)]; Type } \\
\text { locality: Cape Horn; [The name Laminaria } \\
\text { ramosissima is not mentioned in Lamouroux } \\
\text { (1813) despite it was clamed by Etcheverry } \\
\text { (1951)]. Isolectotype (PC0062752) shown. } \\
\text { L.que: [currently Myrodesma quercilolium] }\end{array}$ \\
\hline
\end{tabular}


Table 6.1 continued

\begin{tabular}{|c|c|c|c|c|c|c|}
\hline $\begin{array}{l}\text { Bory de } \\
\text { Saint- } \\
\text { Vincent } \\
1828\end{array}$ & 1 & L. flavicans & L. nigrescens & & L. quercifolia & $\begin{array}{l}\text { Combined L.fla and L.fus into one species, } \\
\text { which he called L.fla (Pl.3 in Bory de Saint- } \\
\text { Vincent } 1828) \text {. } \\
\text { L.nig: (Pl.5 in Bory de Saint-Vincent } 1828)\end{array}$ \\
\hline Suhr 1839 & na & & $\begin{array}{l}\text { Chordaria } \\
\text { spicata }\end{array}$ & & & $\begin{array}{l}\text { Type locality: Valparaiso, fig. } 41 \text { [?], } \\
\text { collector Lucas }\end{array}$ \\
\hline $\begin{array}{l}\text { Postels \& } \\
\text { Ruprecht } \\
1840\end{array}$ & $?$ & & & $\begin{array}{l}\text { L. fuscescens } \\
\text { (L.flavicans) }\end{array}$ & $\begin{array}{l}\text { L. nig } \\
\text { L. } \\
\text { laminariaeoides } \\
\text { L. ciliata }\end{array}$ & $\begin{array}{l}\text { no reference to the collection site; the } \\
\text { transverse sections of the blade of } L . f u s \\
\text { (Tab. XXXIX Fig. 15\&18) show lacunae } \\
\text { with trabeculae }\end{array}$ \\
\hline Suhr 1841 & na & & $\begin{array}{l}\text { Laminaria } \\
\text { scissa }\end{array}$ & & & Type locality: Valparaiso \\
\hline Agardh 1841 & na & & L. suhrii & & & $\begin{array}{l}\text { L.suh: Changed the name Chordaria spicata } \\
\text { into Lessonia suhrii [nom. illeg.; the comb. } \\
\text { nov. Lessonia spicata should have been } \\
\text { made] } \\
\text { Lam.sci: Laminaria scissa can scarcely be } \\
\text { distinguished from L.nig }\end{array}$ \\
\hline
\end{tabular}


Table 6.1 continued

\begin{tabular}{|c|c|c|c|c|c|c|c|}
\hline $\begin{array}{l}\text { Montagne } \\
1842\end{array}$ & na & & & L. berteroana & & & $\begin{array}{l}\text { Type locality: Coquimbo; Collector: Bertero } \\
\text { et cel. Gaudichaud; Montagne: "Could } \\
\text { possibly be a synonym to Cordaria spicata } \\
\text { Suhr" }\end{array}$ \\
\hline $\begin{array}{l}\text { Kuetzig } \\
1843\end{array}$ & $?$ & L. fuscescens & & & & & $\begin{array}{l}\text { p. } 88 \text { the gigantic thick caulom of } L . f u s \text { has } \\
\text { also the biggest vasa mucifera; } \\
\text { p. } 348 \text { states that } L . f u s \text { and L.nig have the } \\
\text { same distribution }\end{array}$ \\
\hline $\begin{array}{l}\text { Gaudichaud } \\
1844-6\end{array}$ & na & & & L. berteroana & L. fuscescens & & $\begin{array}{l}\text { L.ber: Type collected by Gaudichaud and } \\
\text { reported here in more detail; } \\
\text { L.fus: might be L. trabeculata (Ad oras } \\
\text { Peruviae circa Callao) }\end{array}$ \\
\hline $\begin{array}{l}\text { Harvey \& } \\
\text { Hooker } 1847\end{array}$ & 3 & $\begin{array}{l}\text { L. fuscescens } \\
\text { (L. flavicans) } \\
\text { with lacunae } \\
\text { L. nigrescens } \\
\text { with lacunae } \\
{[!]}\end{array}$ & L. ovata & & & & $\begin{array}{l}\text { Both, L.fus sensu H\&H and L.nig sensu } \\
\text { H\&H are depicted with lacunae; However, } \\
\text { L.nig is not found on the Falklands (Searles } \\
\text { 1978) } \\
\text { L.ova: Type locality: Hermit Island (Cape } \\
\text { Horn); has most likely priority to L. } \\
\text { searlesiana. No type has been assigned; } \\
\text { thumbnail shows proposed type } \\
\text { (unnumbered herbarium sheet in BM). }\end{array}$ \\
\hline Agardh 1848 & 2 & L. fuscescens & L. ovata & $\begin{array}{l}\text { L. suhrii } \\
\text { L. nigrescens }\end{array}$ & & $\begin{array}{l}\text { Species } \\
\text { inquirendae: } L . \\
\text { ciliata, } \text { L. } \\
\text { laminariaeoides, } \\
\text { L. sinclairi }\end{array}$ & $\begin{array}{l}\text { L.suh: syn of Chordaria spicata } 1839 \text { and } \\
\text { L.ber (Himanthalia durvillaei (Bory de } \\
\text { Saint-Vincent } 1828 . \text { p. 135) ad Areschougia } \\
\text { ad hanc trahitur) } \\
\text { L.nig: syn Lam. scissa } \\
\text { L.fus: sensu Hooker }\end{array}$ \\
\hline
\end{tabular}


Table 6.1 continued

\begin{tabular}{|c|c|c|c|c|c|c|}
\hline $\begin{array}{l}\text { Kuetzig } \\
1849\end{array}$ & 3 & $\begin{array}{l}\text { L. fuscescens } \\
\text { (L. flavicans) }\end{array}$ & L. ovata & $\begin{array}{l}\text { L. nigrescens } \\
\text { L. berteroana }\end{array}$ & $\begin{array}{l}\text { L. } \\
\text { laminariaeoides }\end{array}$ & $\begin{array}{l}\text { L.fus (L.fla): Hab: ad oras Americae, insula } \\
\text { Falkland, Kerguelensland: in Terra Louis- } \\
\text { Philippe } \\
\text { L.ova: Hab: with former ad Cap Horn, ins. } \\
\text { Falkland, Hermite Isl. } \\
\text { L.nig: Hab: with L.fus [indicating that it is } \\
\text { found on Falkland]; syn of Lam.ram., } \\
\text { Lam.sci., Lessonia binderi Sonder. } \\
\text { [nom.herbariorum? A\&R09] } \\
\text { L.ber: Hab: ad oras Chilenses; syn of L.suh., } \\
\text { Cho.spi. }\end{array}$ \\
\hline $\begin{array}{l}\text { Montagne } \\
1852\end{array}$ & $?$ & L. fuscescens & L. ovata [?] & $\begin{array}{l}\text { L. berteroana } \\
\text { L. nigrescens }\end{array}$ & $\begin{array}{l}\text { L. fuscescens } \\
\text { [?] } \\
\text { L. ovata [?] }\end{array}$ & $\begin{array}{l}\text { L.ber: syn L.suh } 1841 \text { and Chordaria spicata } \\
\text { 1839; Coquimbo; (L.ber has nothing in } \\
\text { common with Himanthalia durvellaei as } \\
\text { reported by Areschoug) } \\
\text { L.nig: syn Laminaria scissa; Concepción, } \\
\text { Valparaiso, etc.[Montagne recognised L.ber } \\
\text { and L.nig] L.fus: often confused with L.nig } \\
\text { and L.ova it was collected at Concepción by } \\
\text { Lesson and Valparaiso by Bertero } \\
\text { L.ova: it was collected at Concepción shores } \\
\text { [Montagne found both species mixed up in } \\
\text { Bory de Saint-Vincent's collection][L.fus --> } \\
\text { might been confused with L. trabeculata]; }\end{array}$ \\
\hline
\end{tabular}


Table 6.1 continued

\begin{tabular}{|c|c|c|c|c|c|}
\hline $\begin{array}{l}\text { J.Agardh } \\
1877\end{array}$ & $?$ & & $\begin{array}{l}\text { L. fuscescens } \\
\text { (partim?) } \\
\text { L. ovata }\end{array}$ & $\begin{array}{ll}\text { L. suhrii } & \text { L. variegata } \\
\text { L. nigrescens } & \end{array}$ & $\begin{array}{l}\text { Agardh makes the point that there are two } \\
\text { sections of Lessonia. The first section } \\
\text { includes those without lacunae as L.suh., } \\
\text { L.nig., L.fus (partim?), L.ova (=L.fus fide } \\
\text { spec.) and the second includes those in Chile } \\
\text { and New Zealand with lacunae. Those with } \\
\text { lacunae he called L. variegata (including } \\
\text { those with lacunae found in Chile). } \\
\text { L.nig: syn Lam.sci }\end{array}$ \\
\hline $\begin{array}{l}\text { Dickie } \\
1877 \mathrm{a} \& \mathrm{~b}\end{array}$ & $?$ & L. fuscescens & L. ovata & L. nigrescens & $\begin{array}{l}\text { Algae from Kerguelen (L.fus) and Heard } \\
\text { Island (L.nig, L.ova); collected by Moseley } \\
\text { during the 'Challenger' expedition }\end{array}$ \\
\hline Hariot 1889 & 3 & $\begin{array}{l}\text { L. fuscescens } \\
\text { L. nigrescens } \\
{[! ?]}\end{array}$ & L. flavicans & L. suhrii & $\begin{array}{l}\text { L.fus (after drawings by Bory de Saint-Vincent } \\
\text { 1828): Hab: Terre de Feu, Malouines, one of the } \\
\text { more common magellanian seaweeds. She is very } \\
\text { abundant in all the canals of Terra del Fuego, } \\
\text { especially in the South, and on the Falklands. } \\
\text { L.fla: syn L.fus (excl. drawings), L.ova; Hab: } \\
\text { Terre de Feu, Malouines; refers to Rostafinski (in } \\
\text { herb. Musei Parisiensis) as the one who re- } \\
\text { established the true meaning of L.fla \& L.fus; } \\
\text { Hariot states that he found an alga in d'Urville's } \\
\text { collection annotated as L.flavicans in Bory de } \\
\text { Saint-Vincent's handwriting, which might be the } \\
\text { original L.fla and nearest to L.ova. } \\
\text { L.nig: Hab: Terre de Feu, Malouines; Hariot } \\
\text { referred to Hooker's (1847) drawings of L.fus [!?] } \\
\text { L.suh: synonymous with Himanthalia durvillaei } \\
\text { (following Areschoug (1884) despite the opposite } \\
\text { opinion of Montagne (1852)) }\end{array}$ \\
\hline
\end{tabular}




\begin{tabular}{|c|c|c|c|c|c|c|}
\hline $\begin{array}{l}\text { J.Agardh } \\
1894\end{array}$ & $?$ & L. fuscescens & L. ovata & $\begin{array}{l}\text { L. Suhrii } \\
\text { L. nigrescens }\end{array}$ & $\begin{array}{l}\text { L. brevifolia } \\
\text { L. variegata }\end{array}$ & $\begin{array}{l}\text { L.fus: two forms with lanceolate-linear } \\
\text { blades, young ones with lacunae, adult ones } \\
\text { with some small lacunae but rare, however } \\
\text { teeth on the edge of the blades are } \\
\text { conspicuouse with nobs at pointed elongated } \\
\text { teeth. } \\
\text { L.ova: ovalo-lanceolate blades, "lacunae } \\
\text { slightly conspicuous, bigger, more or less } \\
\text { equalling several disrupted cells, I have seen } \\
\text { this only here." }\end{array}$ \\
\hline $\begin{array}{l}\text { Skottsberg } \\
1907\end{array}$ & 3 & $\begin{array}{l}\text { L. nigrescens } \\
\text { L. frutescens } \\
\text { [partim. } \\
\text { (habitat } \\
\text { description)] }\end{array}$ & $\begin{array}{l}\text { L. flavicans } \\
\text { L. frutescens } \\
\text { [partim. } \\
\text { (anatomy and } \\
\text { picture)] }\end{array}$ & & & $\begin{array}{l}\text { L.nig: following Hooker (1847) he } \\
\text { recognised and lengthily described a } \\
\text { L.vadosa-like alga as L.nig [he called it later } \\
\text { in } 1921 \text { L.nig f. lacunifera]. } \\
\text { L.fla: his understanding is nearest to L.ova } \\
\text { (following Hariot). } \\
\text { L.fru: he described an intertidal alga that is } \\
\text { nearest to his understanding of L.nig [i.e., } \\
\text { L.nig f.lacunifera or L.vadosa-like but } \\
\text { intertidal; this form is only found on } \\
\text { Falkland; left picture], however, the alga he } \\
\text { got from S.Birger that he used for anatomic } \\
\text { studies and pictured in Taf.8 is a L.fla-like } \\
\text { individual [right picture; lectotype of } L . f r u \\
\text { (A1388 in S)] }\end{array}$ \\
\hline Cotton 1915 & 3 & $\begin{array}{l}\text { L. nigrescens } \\
\text { L. frutescens } \\
\text { [partim. } \\
\text { (habitat } \\
\text { description)] }\end{array}$ & $\begin{array}{l}\text { L. flavicans } \\
\text { L. frutescens } \\
\text { [partim. } \\
\text { (anatomy and } \\
\text { picture)] }\end{array}$ & & & $\begin{array}{l}\text { following Skottsberg } \\
\text { L.nig: besides Skottsberg (Port William) and } \\
\text { Hooker who gave accounts on L.nig at } \\
\text { E.Falkland he also cited Vallentin for L.nig } \\
\text { at W.Falkland (Roy Cove, in rock-pools) }\end{array}$ \\
\hline
\end{tabular}

picture)] at W.Falkland (Roy Cove, in rock-pools) 
Table 6.1 continued

\begin{tabular}{|c|c|c|c|c|}
\hline $\begin{array}{l}\text { Skottsberg } \\
1921\end{array}$ & $?$ & $\begin{array}{l}\text { L. nigrescensf. L. flavicans } \\
\text { lacunifera } \\
\text { L. frutescens }\end{array}$ & $\begin{array}{l}\text { L. nigrescens } f \text {. } \\
\text { montagnei }\end{array}$ & $\begin{array}{l}\text { L.fla: enormous stem, which resembles the } \\
\text { trunk of a small tree; some have lacunae } \\
\text { some do not. "Are there two species? I } \\
\text { hardly think so: the use of this character for } \\
\text { the separation of species, otherwise quite } \\
\text { identical, does not appear very promising." } \\
\text { L.nig: admits that he has not seen a real } \\
\text { L.nig with unbranched haptera on Falkland } \\
\text { and thus divides L.nig in two forms, } \\
\text { f.montagne the 'real' L.nig and f.lacunifera [a } \\
\text { L.vad-like alga]. } \\
\text { L.fru: "Still, it is possible that L.fru is } \\
\text { nothing but a local form of L.nig } \\
\text { [f.lacunifera!]" }\end{array}$ \\
\hline Searles 1978 & 2 & L. flavicans & L. nigrescens undescribed & $\begin{array}{l}\text { L.vad: Type loc: Isla de los Estados; syn } \\
\text { L.nig f.lacunifera; Hab: from Chiloe south } \\
\text { through Beagle Channel and along the } \\
\text { Argentinean coast till Puerto Deseado; } \\
\text { Falkland; shallow subtidal; } \\
\text { L.fla: syn L.fus, L.ova, L.fru; Hab: as L.vad } \\
\text { including Cape Horn; subtidal (3)7-38m } \\
\text { deep; assigned Lectotype to L.fla } \\
\text { L.nig: syn Cho.spi, Lam.sci, L.Suh, L.ber, } \\
\text { L.nig f.montagnei; Hab: Chile \& Peru; lower } \\
\text { intertidal and sublittoral fringe; assigned } \\
\text { Lectotype to L.nig }\end{array}$ \\
\hline $\begin{array}{l}\text { Villouta \& } \\
\text { Santelices } \\
1986\end{array}$ & $?$ & L. flavicans & L. trabeculata & $\begin{array}{l}\text { same concept as Searles } \\
\text { L.tra: Type loc: Coquimbo (MNHN SGO } \\
\text { 102908); selected by J.Vasquez; Hab: Chile } \\
\text { between } 20^{\circ}-40^{\circ} \text { S; subtidal }\end{array}$ \\
\hline
\end{tabular}


Table 6.1 continued

\begin{tabular}{|c|c|c|c|c|c|c|c|}
\hline Hay 1987 & 2 & L. vadosa & L. flavicans & L. nigrescens & L. trabeculata & $\begin{array}{l}\text { L. adamsiae } \\
\text { L. brevifolia } \\
\text { L. corrugata } \\
\text { L. variegata }\end{array}$ & same concept as Searles \\
\hline $\begin{array}{l}\text { Asensi \& de } \\
\text { Reviers } \\
2009\end{array}$ & $?$ & L. flavicans & L. searlesiana & L. nigrescens & L. trabeculata & $\begin{array}{l}\text { all described } \\
\text { species } \\
\text { mentioned }\end{array}$ & $\begin{array}{l}\text { L.fla: re-lectotypification of } L . f l a \text {; found } \\
\text { lacunae in new Lectotype thus changed } \\
\text { Searles concept of L.fla putting his L.vad in } \\
\text { a synonymous status. } \\
\text { L. sea: [is certainly syn of L.ova \& L.fru } \\
\text { (possibly also a syn of L.fus)] }\end{array}$ \\
\hline
\end{tabular}




\subsection{References}

Anonymous. 1859. Circumnavigation of the globe; and progress of maritime discovery from the earliest period to the present time, London $923 \mathrm{pp}$.

Agardh, J. G. 1841. In historiam algarum symbolae. Linnaea 15:1-50, 443-57.

Agardh, J. G. 1848. Species genera et ordines algarum, seu descriptiones succinctae specierum, generum et ordinum, quibus algarum regnum constituitur. Volumen Primum: Algas fucoideas complectens, C.W.K. Gleerup, Lundae pp. [i-vi], [i]-viii, [1]-363.

Agardh, J. G. 1877. De Algis Novae Zelandiae marinis. Lunds Universitets ÅrsSkrift, Afdelningen for Mathematik och Naturvetenskap 14:1-32.

Agardh, J. G. 1894. Analecta algologica. Continuatio II. 30, E. Malmstroems Boktryckeri, Lund, 99 pp.

Asensi, A. \& de Reviers, B. 2009. Illustrated catalogue of types of species historically assigned to Lessonia (Laminariales, Phaeophyceae) preserved at PC, including a taxonomic study of three South-American species with a description of $L$. searlesiana sp. nov. and a new lectotypification of $L$. flavicans. Cryptogam. Algol. 30:209-49.

Bory de Saint-Vincent, J. B. 1825. Cryptogamie. In: Dumont-D'Urville, J. S. C. [Ed.] Flore des Iles Malouines. De L'Imprimerie de Lebel, Imprimeur du Roi, Paris, pp. 21-56 (separate).

Bory de Saint-Vincent, J. B. 1826. Lessonie. Lessonia. In: Audouin, I., et \& al [Eds.] Dictionnaire Classique d'Histoire Naturelle. pp. 321-22. 
Bory de Saint-Vincent, J. B. 1828. Cryptogamie. In: Duperrey, L. I. [Ed.] Voyage autour du monde, exécuté par ordre du Roi, sur la corvette de sa majesté, La Coquille, pendant les années 1822, 1823, 1824 et 1825. Bertrand, Paris, pp. 97-200.

Chamberlain, Y. M. 1965. Marine algae of Gough Island. Bulletin of the British Museum (Natural History) Botany 3:175-232.

Cotton, A. D. 1915. Cryptogams from the Falkland Islands collected by Mrs. Vallentin. Journal of the Linnean Society of London, Botany 43:137-231.

Dickie, G. 1876. Algae collected by Mr. Moseley at Heard Island, 250 miles S. of Kerguelen. Journal of the Linnean Society of London, Botany 15:47-197.

Dunmore, J. 2007. From Venus to Antarctica: the life of Dumont d'Urville. Exisle Pub., Auckland, 252 pp.

d'Urville, J. S. C. 1825. Flore des Iles Malouines. De L'Imprimerie de Lebel, Imprimeur du Roi, Paris, 56 pp. (separate).

d'Urville, J. S. C. 1826. Flore des Iles Malouines. Mémoires de la Société Linnéenne de Paris 4:573-621. Notes: The reprint published October 1825 has priority, but has a different pagination (pp. [i], [1]-56).

Gaudichaud, C. 1826. Botanique. In: De Freycinet, L. [Ed.] Voyage autour du monde...exécuté sur les corvettes de S.M. l'Uranie et la Physicienne, pendant les annés 1817, 1818, 1819 et 1820. Paris, pp. [i]-vii, 1-522. 
Hariot, P. 1889. Botanique: I. Algues. In: Hariot, P., Petit, P., Muller D'Argovie, J., Bescherelle, E., Massalongo, C. \& Franchet, A. [Eds.] Mission Scientifique du Cap Horn. 1882-1883. Gauthier-Villars, Paris, pp. 1-55

Harvey, W. H. \& Hooker, J. D. 1847. Algae. In: Hooker, J. D. [Ed.] The botany of the Antarctic voyage of H.M. discovery ships Erebus and Terror, in the years 1839-1843, under the command of Captain Sir James Clark Ross, Kt., R.N., F.R.S. \&c. Vol. I. Flora Antarctica. Part II. Antarctic Regions, (exclusive of Lord Auckland's group and Campbell's Island) [containing the Botany of Fuegia, the Falklands, Kerguelen's Land, etc.]. Reeve, Brothers, Natural History Lithographers, London, pp. 454-519.

Hay, C. H. 1987. Lessonia adamsiae sp. nov. (Phaeophyta, Laminariales) from the Snares Islands, New-Zealand. N. Z. J. Bot. 25:295-308.

Hooker, J. D. 1847. The botany of the Antarctic voyage of H.M. discovery ships Erebus and Terror, in the years 1839-1843, under the command of Captain Sir James Clark Ross, Kt., R.N., F.R.S. \&c. Vol. I. Flora Antarctica. Part II. Antarctic Regions, (exclusive of Lord Auckland's group and Campbell's Island) [containing the Botany of Fuegia, the Falklands, Kerguelen's Land, etc.]. Reeve, Brothers, Natural History Lithographers, London, 209-574, Plates LXXXI-CXCVII.

Kützing, F. T. 1843. Phycologia generalis oder Anatomie, Physiologie und Systemkunde der Tange. F.A. Brockhaus, Leipzig, pp. [part 1]: [i]-xxxii, [1]142 , [part 2:] 43-458, 1, err.], pls 1-80. 
Kützing, F. T. 1849. Species algarum. F.A. Brockhaus, Lipsiae [Leipzig], [i]-vi, [1]922.

McNeill J. (Chairman), Barrie F.R., Burdet H.M., Demoulin V., Hawksworth D.L., Marhold K., Nicolson D.H., Prado J., Silva P.C., Skog J.E., Wiersema J.H., (Members) \& Turland N.J., S. o. t. E. C. 2006. International Code of Botanical Nomenclature (Vienna Code) adopted by the Seventeenth International Botanical Congress, Vienna, Austria, July 2005 Regnum vegetabile 146. A.R.G. Gantner Verlag KG. XVI, 568.

Montagne, C. 1842. Troisième centurie de plantes cellulaires exotiques nouvelles. Décades V, VI, VII et VIII. Annales des Sciences Naturelles, Botanique, Seconde Série 18:241-82, Plate 7.

Montagne, C. 1852. Botanica. Tomo octavo. Flora Chileana. Plantas cellulares. Tomo segundo. In: Gay, C. [Ed.] Historia fisica y politica de Chile segun documentos adquiridos en esta republica durante doce años de residencia en ella y publicata bajo los auspicios del supremo gobierno.... Thunot, Paris, pp. 256.

Postels, A. \& Ruprecht, F. 1840 (reprint 1963). Illustrationes Algarum. 29, Wheldon \& Wesley, Ltd and Hafner Publishing Co., New York, 24 pp., (with 40 Figures).

Searles, R. B. 1978. Genus Lessonia Bory (Phaeophyta, Laminariales) in Southern Chile and Argentina. Br. Phycol. J. 13:361-81. 
Skottsberg, C. 1907. Zur Kenntnis der Subantarktischen und Antarktischen Meeresalgen I. Phaeophyceen b. Lessoniaea. In: Nordenskjöld, O. [Ed.] Wissenschaftliche Ergebnisse der Schwedischen Südpolar-Expedition, 19011903. Kungl., Boktryckeriet, Stockholm, pp. 69-80.

Skottsberg, C. 1921. Botanische Ergebnisse der Schwedischen Expedition nach Patagonien und dem Feuerlande 1907-1909. VIII Marine Algae 1. Phaeophyceae. Kungliga Svenska Vetenskapsakademiens Handlingar 61:156.

Suhr, J. N. v. 1839. Beiträge zur Algenkunde. Flora 22:65-75.

Suhr, J. N. v. 1841. Beiträge zur Algenkunde. Verhandlungen der Kaiserlichen Leopoldinisch-Carolinischen Akademie der Naturforscher 18:273-88.

Villouta, E. \& Santelices, B. 1986. Lessonia trabeculata sp. nov. (Laminariales, Phaeophyta), a new kelp from Chile. Phycologia 25:81-86. 



\section{Chapter 7 Summary and directions for future research}

General patterns of phylogeographic research of coastal benthic invertebrates and plants have revealed a significant negative correlation between larval duration and genetic differentiation (Ross et al. 2009). Larval duration is not the only factor responsible for the dispersal potential of a species, as studies on Macrocystis and Durvillaea antarctica have shown (Macaya \& Zuccarello 2010, Fraser et al. 2009). Due to the ability of these species to float, they are able to connect populations throughout the Southern Hemisphere and single widespread haplotypes have been observed in both species (Macaya \& Zuccarello 2010, Fraser et al. 2009). My aim was to study a widespread non-floating taxon with limited dispersal abilities but with the possibility of being attached to rafts that enables long distance dispersal. I surveyed Lessonia at different taxonomic and geographic levels while examining the global phylogeny at the generic level (Chapter 2), the phylogeography of Lessonia species in Australasia (Chapter 3), and the population genetics across Cook Strait (Chapter 5).

Data collected in the course of this study revealed the taxonomic relationship and the time of speciation events in Lessonia (Chapter 2), although more work is needed to test hypotheses about the origin of Lessonia. Some concrete hypotheses were formulated to describe the dispersal history of Lessonia in New Zealand (Chapter 3). I identified features and processes that create and maintain genetic breaks, emphasizing the importance of rafting as a means to connect meta- 
populations (Chapter $3 \& 5$ ). The known biodiversity has been increased by three species, which remain to be formally described (Chapter $2 \& 3$ ). New microsatellite markers have been developed to study genetic differences within and between populations (Chapter 4). I also clarified the nomenclatural confusion among South American Lessonia (Chapter 6) based on an extensive literature research. This was necessary as the confusion led to wrongly assigned species in publications and in GenBank. Alignments of sequences assigned to the Falkland Islands in GenBank support the occurrence of two different species. However, the affiliation to the species is misleading (Table 7.1).

Table 7.1 Lessonia haplotypes from GenBank. Sp., species affiliation according to this Chapter; det., determined (species affiliation in GenBank according to the Author). L.fla, L. flavicans; L.ova, L. ovata; L.vad, L. vadosa; atp8, spacer region between atp-dehydrogenase subunit 8 and t-RNA serine; trnW-sp, the spacer between the t-RNA's for tryptophan and isoleucine; nd6, a partial sequence of the gene coding for NADH dehydrogenase subunit 6; rbc, spacer between the large and short subunit of the ribulose-1;5-bisphosphate carboxylase/oxygenase gene; ITS, nuclear marker covering the internal transcribed spacers ( 1 and 2 ) between the large and small-ribosomal RNA subunits; and the 5.8S ribosomal RNA; gb, GenBank accession number; code, haplotype in the network.

$\begin{array}{llllll}\text { Sp. } & \text { det. } & \text { marker } & \text { gb } & \text { sample site } & \text { code } \\ \text { L.fla } & \text { L.vad } & \text { atp8 } & \text { GU593743.1 } & \text { Patagonia } & 1 . \mathrm{a} \\ \text { L.fla } & \text { L.vad } & \text { atp8 } & \text { GU593742.1 } & \text { Patagonia } & 1 . \mathrm{a} \\ \text { L.fla } & \text { L.vad } & \text { atp8 } & \text { GU593741.1 } & \text { Patagonia } & 1 . \mathrm{a} \\ \text { L.fla } & \text { L.vad } & \text { atp8 } & \text { GU593740.1 } & \text { Patagonia } & 1 . \mathrm{b} \\ \text { L.fla } & \text { L.vad } & \text { atp8 } & \text { GU593739.1 } & \text { Patagonia } & 1 . \mathrm{b} \\ \text { L.fla } & \text { L.fla } & \text { atp8 } & \text { FJ410130.1 } & \text { Patagonia } & 1 \\ \text { L.fla } & \text { L.vad } & \text { atp8 } & \text { GU593738.1 } & \text { Falkland } & 2 \\ \text { L.fla } & \text { L.vad } & \text { atp8 } & \text { GU593737.1 } & \text { Falkland } & 2 \\ \text { L.fla } & \text { L.vad } & \text { atp8 } & \text { GU593736.1 } & \text { Falkland } & 2 \\ \text { L.fla } & \text { L.vad } & \text { atp8 } & \text { Seal001 }(-10 m) & \text { Falkland } & 2 \\ \text { L.fla } & \text { L.vad } & \text { atp8 } & \text { Xmas001 (-17m) } & \text { Falkland } & 2 . a \\ \text { L.fla } & \text { L.vad } & \text { atp8 } & \text { BEAU2 }(-15 m) & \text { Falkland } & 2 . a \\ \text { L.ova } & \text { L.vad } & \text { atp8 } & \text { EU652986.1 } & \text { Patagonia } & 3 . a \\ \text { L.ova } & \text { L.fla } & \text { atp8 } & \text { GREEN1 (-20m) } & \text { Falkland } & 3 \\ \text { L.ova } & \text { L.fla } & \text { atp8 } & \text { BEAU4 }(-20 m) & \text { Falkland } & 3\end{array}$

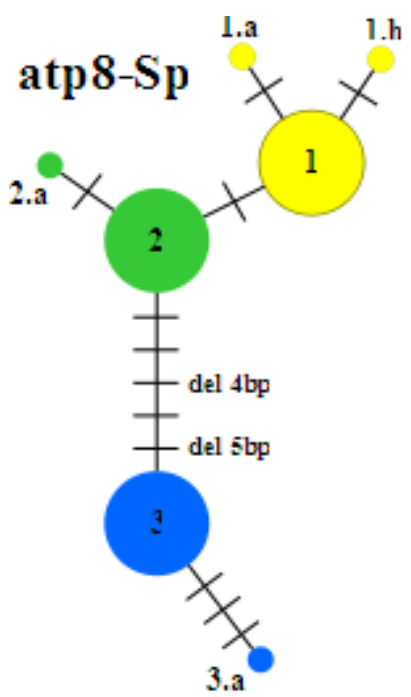


Table 7.1 continued

Sp. det. marker gb

L.fla L.vad trnW

L.fla L.vad trnW

L.fla L.vad trnW

L.fla L.vad trnW

L.fla L.vad trnW

L.fla L.vad trnW

L.fla L.vad trnW

L.fla L.vad trnW

L.ova L.fla trnW

L.ova L.vad trnW
GU593943.1

GU593942.1

GU593941.1

GU593940.1

GU593939.1

GU593938.1

GU593937.1

GU593936.1

EU652961.

EU652962. sample site code

Patagonia 1

Patagonia 1

Patagonia 1

Patagonia

Patagonia

Falkland

Falkland

Falkland

Patagonia

Patagonia
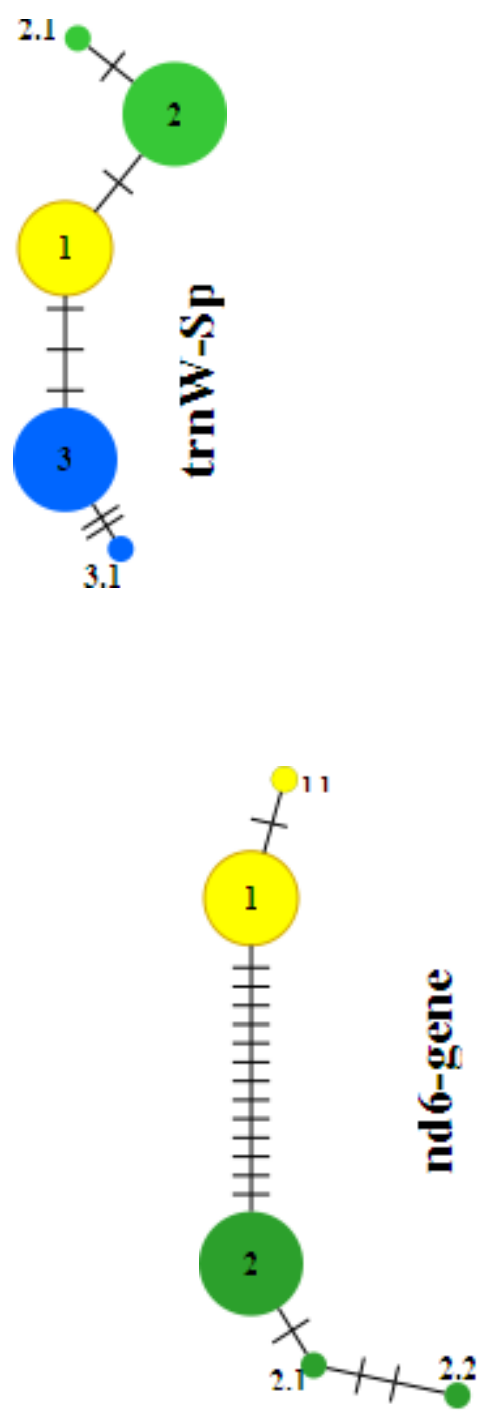

Table 7.1 continued

Sp. det. marker

L.fla L.vad nad6

$\mathrm{gb}$

sample site code

L.fla L.vad nad6

GU593843.1 Patagonia

GU593842.

Patagonia

L.fla L.vad nad6

GU593841.

Patagonia

L.fla L.vad nad6

GU593840.

Patagonia

GU593839.1 Patagonia

GU593838.1 Falkland

GU593837.1 Falkland

GU593836.1 Falkland

AY857931.1 Falkland

1
1
1
1.1
1.1
2.1
2.2
2
2

L.fla L.vad nad6

L.fla L.vad nad6

Table 7.1 continued

$\begin{array}{llllll}\text { Sp. } & \text { det. } & \text { marker } & \text { gb } & \text { sample site } & \text { code } \\ \text { L.fla } & \text { L.vad } & \text { rbc } & \text { GU593893.1 } & \text { Patagonia } & 1 \\ \text { L.fla } & \text { L.vad } & \text { rbc } & \text { GU593892.1 } & \text { Patagonia } & 1 \\ \text { L.fla } & \text { L.vad } & \text { rbc } & \text { GU593891.1 } & \text { Patagonia } & 1 \\ \text { L.fla } & \text { L.vad } & \text { rbc } & \text { GU593890.1 } & \text { Patagonia } & 1 \\ \text { L.fla } & \text { L.vad } & \text { rbc } & \text { GU593889.1 } & \text { Patagonia } & 1 \\ \text { L.fla } & \text { L.fla } & \text { rbc } & \text { FJ410101.1 } & \text { Patagonia } & 1 \\ \text { L.fla } & \text { L.fla } & \text { rbc } & \text { AF318992.1 } & \text { Patagonia } & 1 \\ \text { L.fla } & \text { L.vad } & \text { rbc } & \text { GU593888.1 } & \text { Falkland } & 2 \\ \text { L.fla } & \text { L.vad } & \text { rbc } & \text { GU593887.1 } & \text { Falkland } & 2 \\ \text { L.fla } & \text { L.vad } & \text { rbc } & \text { GU593886.1 } & \text { Falkland } & 2 \\ \text { L.fla } & \text { L.fla } & \text { rbc } & \text { AY851543.1 } & \text { Falkland } & 2 \\ \text { L.ova } & \text { L.vad } & \text { rbc } & \text { FJ410102.1 } & \text { Patagonia } & 3 \\ \text { L.ova } & \text { L.vad } & \text { rbc } & \text { AF318993.1 } & \text { Chubut, AR } & 3\end{array}$

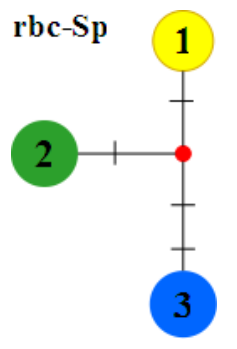


Table 7.1 continued

$\begin{array}{llllll}\text { Sp. } & \text { det. } & \text { marker } & \text { gb } & \text { sample site } & \text { code } \\ \text { L.fla } & \text { L.vad } & \text { ITS } & \text { GU593793.1 } & \text { Patagonia } & 1 \\ \text { L.fla } & \text { L.vad } & \text { ITS } & \text { GU593792.1 } & \text { Patagonia } & 1 \\ \text { L.fla } & \text { L.vad } & \text { ITS } & \text { GU593791.1 } & \text { Patagonia } & 1 \\ \text { L.fla } & \text { L.vad } & \text { ITS } & \text { GU593790.1 } & \text { Patagonia } & 1 \\ \text { L.fla } & \text { L.vad } & \text { ITS } & \text { GU593789.1 } & \text { Patagonia } & 1 \\ \text { L.fla } & \text { L.fla } & \text { ITS } & \text { AF319031.1 } & \text { Patagonia } & 1 \\ \text { L.fla } & \text { L.vad } & \text { ITS } & \text { GU593788.1 } & \text { Falkland } & 2 \\ \text { L.fla } & \text { L.vad } & \text { ITS } & \text { GU593787.1 } & \text { Falkland } & 2 \\ \text { L.fla } & \text { L.vad } & \text { ITS } & \text { GU593786.1 } & \text { Falkland } & 2 \\ \text { L.fla } & \text { L.fla } & \text { ITS } & \text { AY857900.1 } & \text { Falkland } & 2 \\ \text { L.ova } & \text { L.vad } & \text { ITS } & \text { FJ410083.1 } & \text { Patagonia } & 3 \\ \text { L.ova } & \text { L.vad } & \text { ITS } & \text { FJ410059.1 } & \text { Patagonia } & 3 \\ \text { L.ova } & \text { L.vad } & \text { ITS } & \text { AF319032.1 } & \text { Chubut, AR } & 3.1\end{array}$

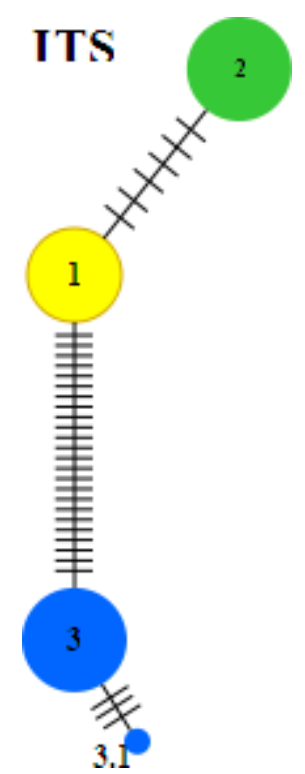

\subsection{What processes maintain genetic breaks in the distribution of} Lessonia in New Zealand?

Genetic (e.g., Apte \& Gardner 2002, Waters \& Roy 2004, Ayers \& Waters 2005, reviewed in Ross et al. 2009) and biogeographic (Shears et al. 2008, Ministry of Fisheries \& Department of Conservation 2008; hereafter called MPA 2008) breaks have been studied in the New Zealand marine environment to aid in conservation planning, to understand recruitment pathways, or to identify processes structuring marine ecosystems. Using mitochondrial and chloroplast markers I tested whether genetic breaks in Lessonia correspond to biogeographic and phylogeographic breaks found earlier. The haplotype distribution was mapped in order to find genetic breaks and to show the distribution range and boundaries of the Australasian species based on more extensive sampling (Chapter 3). Within the distribution area of Lessonia in New Zealand, the genetic breaks have been found to correspond well to existing biogeographic classifications (Fig. 3.1 and 3.6). 
Newly developed microsatellite markers (Chapter 4) were used to investigate the influence of geographic breaks on the connectivity of populations. The Cook Strait area was selected as a study site to compare the genetic differences found between two geographic breaks of similar width, Cook Strait (a seaway separating the North and South Island of New Zealand) and Palliser Bay (a gap created by unsuitable coastline), and the genetic variation within and between populations along a continuous coastline (Chapter 5). The results, based on the frequencies of five microsatellite markers, indicated only a weak genetic barrier between populations separated by Cook Strait, and no differences have been found between three connected populations at the east side of Cook Strait over a distance of $32 \mathrm{~km}$, but a strong break was detected between two populations separated by Palliser Bay. The differences in the strength of genetic breaks between the two gaps suggested that stronger currents within Cook Strait might be responsible for enhanced connectivity (Chapter 5). Longer stretches of unsuitable habitat (e.g., 40km separating $L$. variegata/W and L. variegata/K) have been shown to act as barriers to gene flow and maintain differentiation between species (Chapter 3). Thus the strength of a genetic break is correlated to the width of unsuitable habitat and to the strength of connecting currents. The atp8-sp haplotype distribution (Fig. 3.6) indicates that breaks between Lessonia species are often linked to either eddies (e.g., the break at East Cape between L. variegata/N and L. variegata/W) or stretches of unusable habitat (e.g., the break east of the Marlborough Sounds between L. variegata/W and L. variegata/K or the break spanning Pegasus and Canterbury Bay between $L$. variegata/K and L. variegata/S). Upwelling north of Kaikoura was sometimes used to explain genetic breaks between northern and southern haplotypes (Apte \& Gardner 2002, Waters \& Roy 2004, Ayers \& Waters 2005). This oceanographic 
process can be dismissed as the reason for the genetic differentiation between $L$. variegata/W and L. variegata/K as the distribution of the Kaikoura lineage extended to the north across the upwelling zone. Also, this upwelling region is of postglacial origin and might be too young to fully explain genetic differentiation at the species level (Goldstien et al. 2006). However, within the Kaikoura lineage, the populations north of the upwelling zone have a unique haplotype different from their southern populations indicating that in Lessonia upwelling might play a role in metapopulation structure. Additional research on L. variegata/K with fine scale markers might help to understand the structuring process of this upwelling zone.

\subsection{How important is rafting as a means of dispersal in Lessonia?}

The different dispersal mechanisms have been summarized in the introduction (Chapter 1.3; Fig. 1.10). For the case study of connectivity within Cook Strait I systematically excluding some possible dispersal mechanisms (i.e., first, the maximum distance measured for dispersal of propagules in other Laminariales was only a fraction of the $20+\mathrm{km}$ needed to cross Cook Strait or Palliser Bay; $4 \mathrm{~km}$ for Pterygophora californica propagules (Reed 1988), $3.5 \mathrm{~km}$ for Macrocystis pyrifera propagules (Reed 2004); second, the sea floor topography within Cook Strait and Palliser Bay prevents dispersal of detached algae or dispersal by saltation). As a consequence I concluded that rafting (i.e., as an associate to a float) was important as a means to connect populations across Cook Strait and Palliser Bay (Chapter 5). The weak genetic break detected between populations on both sides of Cook Strait might further suggest that rafting is not rare. As mentioned above, the strength of a genetic break is correlated to the width of unsuitable habitat and/or to the strength of connecting currents. As a consequence, I assume rafting to be very important for 
dispersal in Lessonia and in some cases it might be the only means to connect populations further than $20 \mathrm{~km}$ apart. However little is known about rafting in Lessonia, neither whether it is the gametophyte or the sporophyte that is most successful nor what floating material might be used. Further research is suggested to find out the relative abundance of Lessonia sporophytes that grow on, or are overgrown by Durvillaea antarctica or Macrocystis pyrifera, the two most common rafting species in the Cook Strait area. Fox \& Swanson (2007) used nested PCR to detect gametophytes of Laminariales on rocks; the same method might be modified to detect Lessonia gametophytes on attached and floating specimens of Durvillaea and Macrocystis. During my study I detected haplotypes of New Zealand lineages in samples from Chile (data not shown) together with the expected Chilean haplotype, indicating that dispersal from New Zealand to Chile is possible, ongoing, and not rare (given the relatively small number of South American specimens surveyed).

\subsection{How many Lessonia species are there?}

Currently nine Lessonia species are recognised (see Introduction) but with the use of molecular methods, cryptic species were detected. Recently L. nigrescens has been split into two species (Tellier et al. 2009) though the whole species range of $L$. nigrescens was not investigated. In the current study L. variegata was found to be polyphyletic and four cryptic species were detected (Chapter 2). Each of these species was confined to a distinct area (Chapter 3). Genetic differentiation was also found in L. trabeculata but the surveyed populations were located very far apart, thus it was interpreted as a result of isolation by distance rather than speciation. I interpreted the genetic differentiation within L. flavicans in the same way (Chapter 2). Lessonia flavicans, L. ovata, and L. nigrescens (Dickie 1876 a \& b and 1879, 
Delepine 1963)) are reported from the remote islands, Kerguelen and Heard. As connectivity with South America or Australasia might be very low there is a good chance that these are in fact undescribed species. At present thirteen Lessonia species can be genetically recognised.

Additional research is needed to survey the status of Lessonia on Kerguelen and Heard Island (i.e., whether they are known or new species). The inclusion of these species into an overall phylogeny (Chapter 2) might improve the interpretation of the Southern Hemisphere phylogeography and dispersal history of this genus. Further research is also needed to investigate the morphology of the cryptic species found in L. nigrescens and L. variegata (Chapter 2\&3) in order to be formally described.

Four traits, which were peviously used to describe and differentiate known species, were preliminary studied (Fig. 7.1-7.4, Table 7.2). These traits were colour and colour pattern on the lamina, the appearance of the holdfast, the number of stipes emerging from the holdfast, and the occurrence of lacunae within the blade.

With few exceptions, only individuals of the Wellington lineage ( $L$. variegata/W) possess variegations on the blades (Fig. 7.1), whereas the blades of the other L. variegata lineages are uni-coloured (Fig. 7.3). The exceptions are some northern-lineage (L. variegata/N) populations on the Coromandel Peninsula (Sailors Grave) where variegated blades were found (Fig. 7.2). However, as the variegations appear longer and rather parallel to each other and to the edge of the blade they differ from those of the Wellington lineage, which are short and scattered (Fig. 7.1). All features used to describe L. variegata fit the Wellington lineage and as Wellington 
(Lyall Bay) is also the type locality of L. variegata, I consider this lineage as the true L. variegata (Chapter 2).

The holdfast morphology is another feature, which was often used to differentiate Lessonia species and some species (L. tholiformis, L. trabeculata, or individuals belonging to the L. nigrescens species complex) can be recognised on holdfast morphology alone. Also in L. variegata, the holdfast differs between the lineages (Fig. 7.1-7.3). In L. variegata/W the holdfast is a massive woody structure that forms a rib-like buttress with numerous primary stipes (Fig. 7.1). No buttresses are formed in the northern lineage and the holdfast forms an appressed network on the substrate (Fig. 7.2). Young stipes at early stages might grow along the bottom surface and produce additional haptera thus forming a flat, central hapteron. Many long primary branches emerge from the flat holdfast. Stipes and branches are often flat, too. The holdfast of the Kaikoura (L. variegata/K) and Southern lineage ( $L$. variegata/S) are very much alike and hard to distinguish (Fig. 7.3). They do not form a buttress (in contrast to L. variegata/W) but are not appressed to the ground either (in contrast to L. variegata/N); instead they form a doom-like structure but, in contrast to $L$. tholiformis, with very distinctive haptera. In L. variegata/K numerous stipes emerge from this holdfast whereas in L. variegata/S the stipes are few (Fig. 7.3). In both lineages, but more so in L. variegata/S, the stipes and branches are short.

A fourth feature used is the occurrence of lacunae in the blades, which is used as a distinguishing characteristic in other Lessonia species. All L. variegata lineages have lacunae (Fig. 7.4), however, they are numerous and large in $L$. variegata/W and numerous but small in L. variegata/ $\mathrm{N}$. They are less frequent (2- 
$3 / \mathrm{mm}$ in a transverse section) in L. variegata/S and they are rare in L. variegata/K (average of $1 / \mathrm{mm}$ in a transverse section).

The four morphological and anatomical characteristics appear promising in their ability to differentiate between the four lineages of the L. variegata species complex. However, the small sample size used does not guarantee that any of these characters is species-specific as the within species variability is unknown and only the Wellington lineage has been proven to be easily distinguished by sight (pers. observation). 


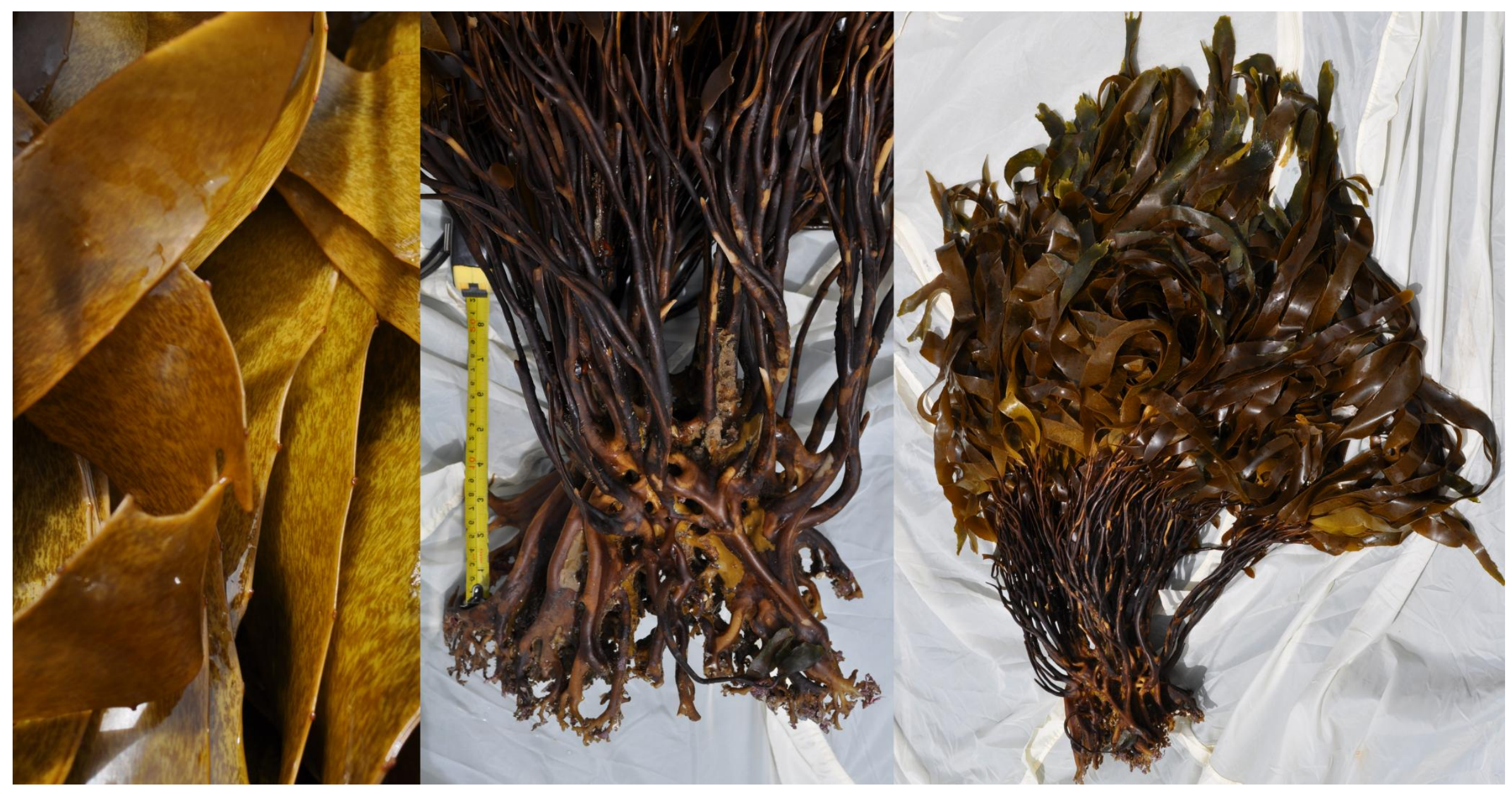

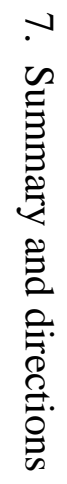

Fig. 7.1 L. variegata/W displaying morphological features of the 'real' L. variegata; sampled at Lyall Bay in Wellington (Type locality); left: close up on blades showing variegation; middle: close up on buttress; right whole alga. 


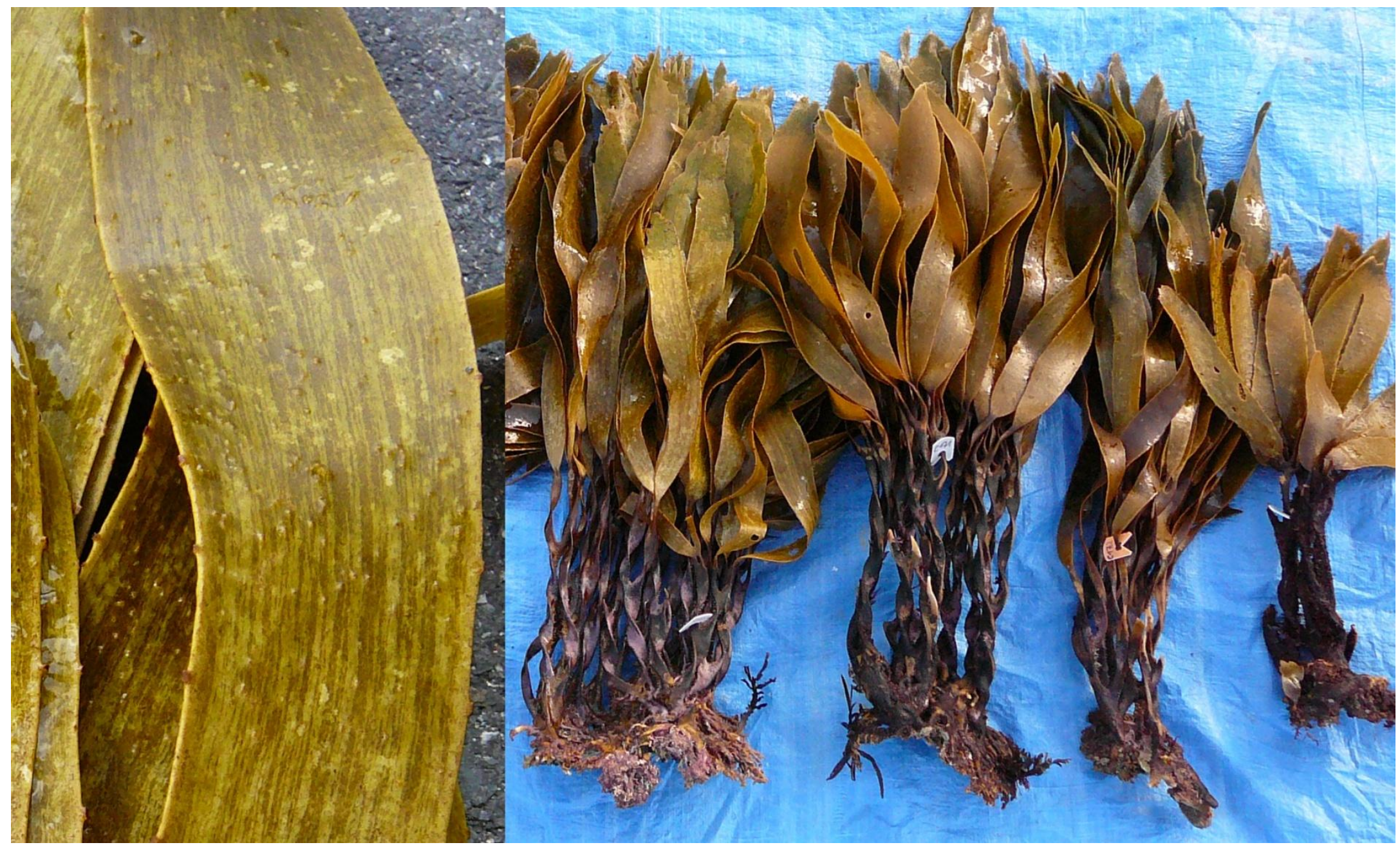

Fig. 7.2 L. variegata/N multiple stipes arose from a flattened holdfast; blades, which are normally uni-coloured show long and parallel variegations in some populations (left). 


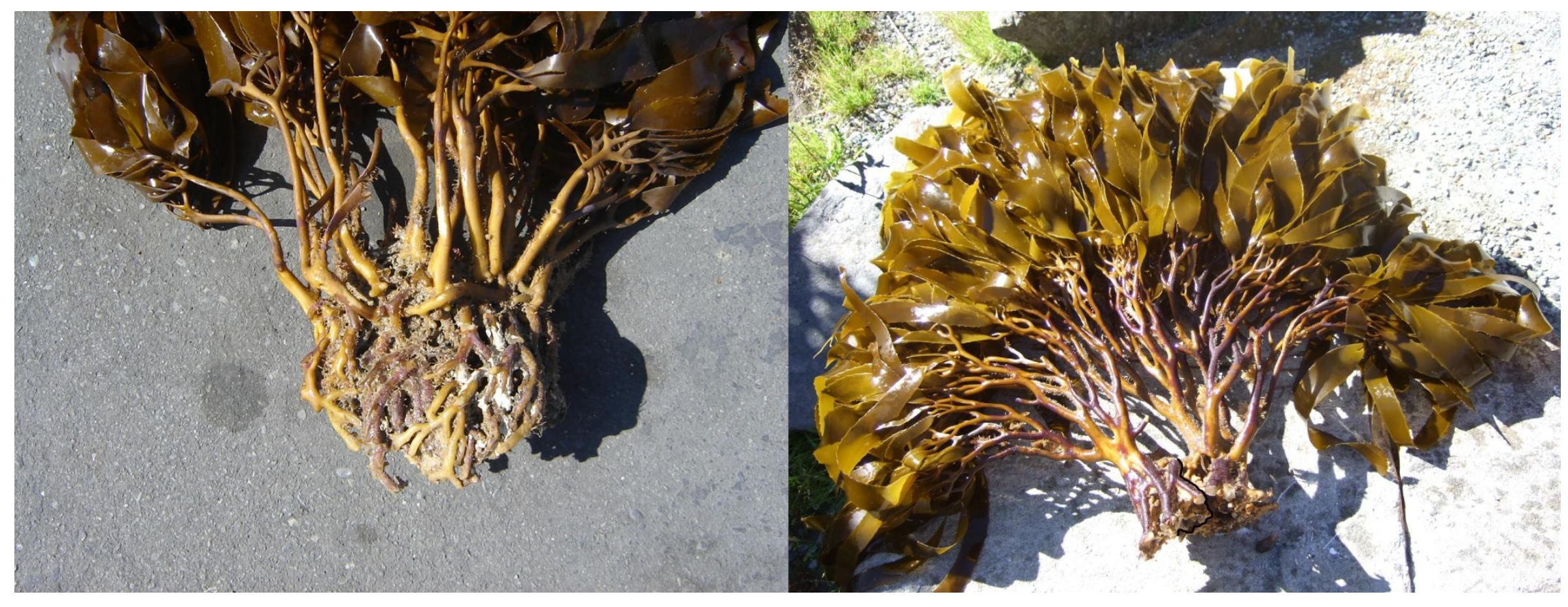

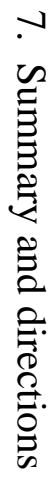

Fig. 7.3 Multiple stipes emerge from the holdfast in L. variegata/K (left), but only a few from L. variegata/S (right; showing two algae). 


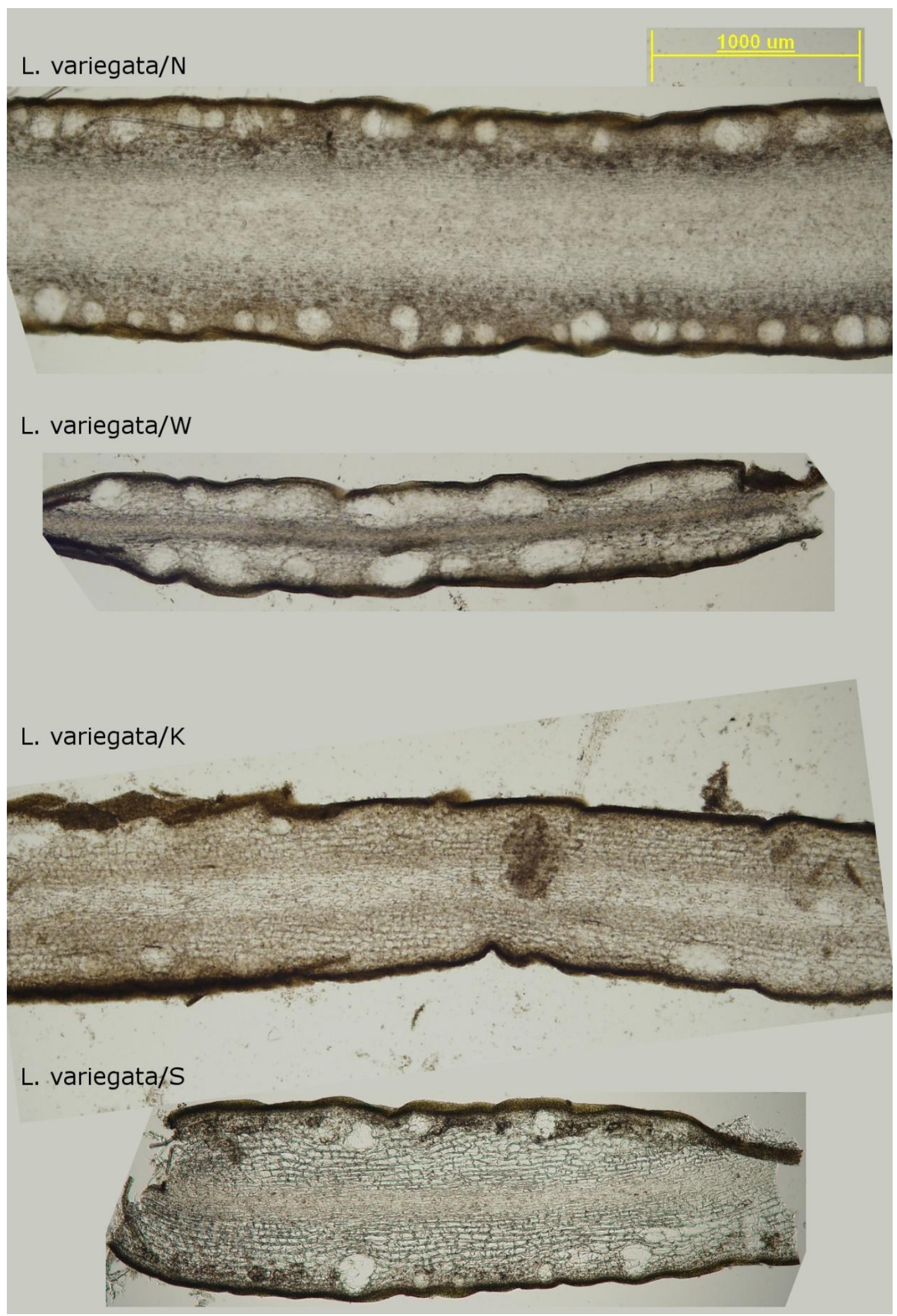

Fig. 7.4 Transverse sections showing possible differences between the four L. variegata lineages as specified in Table 7.1. 
Table 7.2 Morphological characteristics and habitat of L. variegata lineages (tentative).

\begin{tabular}{|c|c|c|c|c|}
\hline Feature & L. variegata/W & L. variegata/N & L. variegata/K & L. variegata/S \\
\hline Lamina colour & $\begin{array}{l}\text { light brown to } \\
\text { yellow; } \\
\text { variegated }\end{array}$ & $\begin{array}{l}\text { light brown to } \\
\text { green often } \\
\text { brighter at the } \\
\text { edge }\end{array}$ & \multicolumn{2}{|c|}{ brown } \\
\hline Lacunae & numerous, big & numerous, small & few $(2-3 / \mathrm{mm})$ & $\begin{array}{l}\text { rare (in average } \\
1 / \mathrm{mm})\end{array}$ \\
\hline Holdfast & $\begin{array}{l}\text { massive, woody; } \\
\text { dichotomously } \\
\text { branched haptera }\end{array}$ & $\begin{array}{l}\text { Flat appressed } \\
\text { on the substrate; } \\
\text { at least in young } \\
\text { algae flattened } \\
\text { stipes with the } \\
\text { ability to } \\
\text { produce haptera }\end{array}$ & \multicolumn{2}{|c|}{$\begin{array}{l}\text { Massive, building half of a sphere; } \\
\text { haptera very distinct not moulded }\end{array}$} \\
\hline Buttress & rib-like & \multicolumn{3}{|c|}{ no } \\
\hline $\begin{array}{l}\text { Stipes } \\
\text { emerging from } \\
\text { holdfast }\end{array}$ & & up to 20 and more & & few \\
\hline
\end{tabular}




\subsection{Where did Lessonia originate?}

The main results of the global phylogeny have been that the Australasian species form a clade nested within a paraphyletic group of South American species. The South American species form a pectinate or unbalanced tree base with L. flavicans in a sister relationship to the Australasian clade (Chapter 2). Although the supermatrix approach (multiple matrices, i.e., atp8-sp, trnW-sp, nd6-gene, rbc-sp, and ITS datasets, were combined into one supermatrix) gave good support to the phylogeny of Lessonia, no phylogeographic conclusions were made as to the place of the origin of Lessonia.

In the following I will describe two different hypothetical dispersal scenarios (Chapter 2) and introduce a third scenario that combines our present day knowledge of the relationship and distribution of Lessonia haplotypes.

According to the standard hypothesis as used in DIVA or TREEFITTER (Sanmartin et al. 2007, fig. 3) and given the phylogeny as shown in Fig. 2.2, Lessonia would have originated in South America and a single dispersal event would have predated the radiation in Australasia, as the Australasian clade is nested within a paraphyletic group of lineages from South America. This phylogeographic interpretation of the phylogeny has not been contested for many years but, for dispersive species where unidirectional currents are the main dispersal agents, the same phylogeny can be interpreted differently (Crisp \& Cook 2005). Following the 'nested ancestral area' hypothesis (Cook \& Crisp 2005) Australasia would be origin of Lessonia and source of multiple dispersal events, which would have led to multiple colonisations into the downstream area (i.e., South America). The rarer 
those dispersal events are the more like they will lead to allopatric speciation (Thiel \& Haye 2006). These two hypotheses are the extremes of more, equally parsimonious, hypotheses that follow the 'nested ancestral area' hypothesis but with a different starting point (e.g., a South American origin of Lessonia followed by dispersal to Australasia, which becomes the nested ancestral area for the remaining South American species). These intermediate hypotheses are special cases when unidirectional agents form ring systems like the WWD in the southern Oceans but are not possible, for example, in river systems, where unidirectional dispersal might also occur. In any case, all these phylogeographic hypotheses are interpretations of the same phylogeny, thus in systems with unidirectional dispersal no conclusions regarding the ancestral area can be drawn based on the phylogeny alone (Cook \& Crisp 2005, Crisp \& Cook 2005).

Currently DIVA (Ronquist 1997) is the most used program to infer ancestral areas, even though it is only able to reconstruct simple evolutionary histories and fails if dispersal patterns are more complex (Kodandaramaiah 2010). In the past, programs to infer complex evolutionary histories have not been available but currently many programs are in development to address this problem. Kodandaramaiah (2010) concludes that model-based methods are promising in determining ancient dispersal patterns. But also simulation tools like IMa2 (Isolation with migration; Hey 2010a \& b) might be altered in a way to test different dispersal hypotheses in species rather then populations. The key to answer the question about the origin of Lessonia might lay in South America, since, if the 'nested ancestral area' hypothesis is valid, each South American species must have gone through a bottleneck as the result of the founder effect, which should have followed the long 
distance dispersal with colonisation events (Thiel \& Haye 2006, Wilson et al. 2009). Different programs, e.g., IMa2, are able to detect bottlenecks, but more sampling in South America would be required.

Additional extensive sampling might be required to discriminate between the different dispersal hypotheses, thus research would benefit from a method that might allow making inferences based on the dataset used to acquire the phylogeny. I propose that gene networks would reflect the differences of the alternative phylogeographic hypotheses, i.e., the networks would be starlike if reflecting the ancestral area hypothesis and not starlike if reflecting the standard hypothesis. If true, this would be an easy method to test phylogeographic hypotheses; however, it might also be an oversimplification. Different evolutionary histories might generate starlike species networks and starlike networks might be an artefact of markers evolving too slowly to detect the true pattern of speciation. In the case of Lessonia, starlike networks were generated with the rapidly evolving mitochondrial atp8-sp and trnW-sp, but non-starlike networks resulted from the chloroplast rbc-sp, and the nuclear ITS1, and ITS2 dataset (networks not shown). Thus the mitochondrial spacer regions might support a 'nested ancestral area' hypothesis whereas the chloroplast and nuclear spacer regions might not.

More sampling and more data in addition to a better understanding of organelle inheritance and speciation processes (e.g., speciation through hybridisation) are needed to fully resolve questions about the origin and dispersal history of Lessonia. However, it is worth considering a different hypothesis can be determined based on the contrary information gained by the single marker networks (mitochondrial-DNA vs. chloroplast- and nuclear-DNA). This hypothesis would 
invoke South America as the origin of Lessonia. Long distance dispersal of individuals following the WWD would have led to the colonisation of Australasia. Australasia would become the nested ancestral area of all remaining Lessonia (as in the intermediate hypothesis mentioned above). However, dispersal back to South America would not create new species due to allopatric speciation, but due to hybridisation. This interpretation would combine the conflicting hypotheses inferred from single marker networks of the mitochondrial, chloroplast, and nuclear-DNA, without being in conflict with the phylogenetic calculations of the combined dataset.

The validity of any of these dispersal hypothesis remains to be tested. As algae do not fossilize well, clues have to be found elsewhere e.g., in geological and climatic history and processes, or in the comparison with other live forms that share the same habitat, or the same distribution, or the same dispersal abilities. The use of different markers and the comparison of gene trees might be helpful, as well as the use of different methods or models like trees, splittrees, supertrees (a tree derived from the combination of different gene trees), networks, and methods to infer coalescence and demography, but also methods to simulate different scenarios where hypotheses can be tested on artificial datasets to compare the output with the original data.

While the global phylogeography remains speculative, but might be narrowed down to fewer possibilities with developing tools and increasing knowledge, more could be inferred about the phylogeography of Lessonia in Australasia. In Chapter 3, the relationship and distribution of haplotypes was combined with knowledge of the recent and past geography of the area to infer phylogeographic hypotheses and to reconstruct the dispersal history of Lessonia in Australasia. Thus I formulated the 
hypotheses about the post glacial dispersal history of $L$. corrugata, the dispersal history of $L$. variegata/W, and the possibility of hybrid speciation of L. adamsiae from a cross between L. variegata/S and L. corrugata. As pointed out in Chapter 3, the hypothesis of the post glacial dispersal history of $L$. corrugata can be tested by sequencing samples from the west coast of Tasmania to search for the proposed intermediate haplotypes. The finding of these haplotypes would strengthen the hypotheses of a proposed north-western refugium followed by postglacial dispersal along both sides of Tasmania (Fig. 3.5).

\subsection{References}

Apte, S. \& Gardner, J. P. A. 2002. Population genetic subdivision in the New Zealand greenshell mussel (Perna canaliculus) inferred from single-strand conformation polymorphism analysis of mitochondrial DNA. Mol. Ecol. $11: 1617-28$

Ayers, K. L. \& Waters, J. M. 2005. Marine biogeographic disjunction in central New Zealand. Mar. Biol. 147:1045-52.

Cook, L. G. \& Crisp, M. D. 2005. Directional asymmetry of long-distance dispersal and colonization could mislead reconstructions of biogeography. J. Biogeogr. $32: 741-54$

Crisp, M. D. \& Cook, L. G. 2005. Do early branching lineages signify ancestral traits? Trends Ecol. Evol. 20:122-28.

Delepine, R. 1963. Observations sur la végétation marine des îles Australes Françaises. Société Phycologique de France 8:9-10. 
Dickie, G. 1876. Algae collected by Mr. Moseley at Heard Island, 250 miles S. of Kerguelen. Journal of the Linnean Society of London, Botany 15:47-197.

Dickie, G. 1876. Marine algae collected by Mr. Moseley at the island of Kerguelen. Journal of the Linnean Society of London, Botany 15:43-47.

Dickie, G. 1879. Marine algae (exclusive of the Diatomaceae). Philos. Trans. R. Soc. Lond. B Biol. Sci. 168 (extra vol.):53-64.

Fox, C. H. \& Swanson, A. K. 2007. Nested PCR detection of microscopic life-stages of laminarian macroalgae and comparison with adult forms along intertidal height gradients. Marine Ecology Progress Series - unpublished.

Fraser, C. I., Nikula, R., Spencer, H. G. \& Waters, J. M. 2009a. Kelp genes reveal effects of Sub-Antarctic sea ice during the Last Glacial Maximum. Proc. Natl. Acad. Sci. U. S. A. 106:3249-53.

Goldstien, S. J., Schiel, D. R. \& Gemmell, N. J. 2006. Comparative phylogeography of coastal limpets across a marine disjunction in New Zealand. Mol. Ecol. 15:3259-68.

Hey, J. 2010a. Isolation with migration models for more than two populations. Mol. Biol. Evol. 27:905-20.

Hey, J. 2010b. The divergence of Chimpanzee species and subspecies as revealed in multipopulation Isolation-with-Migration analyses. Mol. Biol. Evol. 27:92133.

Kodandaramaiah, U. 2010. Use of dispersal-vicariance analysis in biogeography - a critique. J. Biogeogr. 37:3-11. 
Macaya, E. C. \& Zuccarello, G. C. 2010. DNA barcoding and genetic divergence in the giant kelp Macrocystis (Laminariales). J. Phycol. 46:736-42.

Ministry of Fisheries and Department of Conservation 2008. Marine Protected Areas: Classification, Protection Standard and Implementation Guidelines. Ministry of Fisheries and Department of Conservation, Wellington, 54 pp.

Reed, D. C., Laur, D. R. \& Ebeling, A. W. 1988. Variation in algal dispersal and recruitment. Ecol. Monogr. 58:321-35.

Reed, D. C., Schroeter, S. C. \& Raimondi, P. T. 2004. Spore supply and habitat availability as sources of recruitment limitation in the giant kelp Macrocystis pyrifera (Phaeophyceae). J. Phycol. 40:275-84.

Ross, P. M., Hogg, I. D., Pilditch, C. A. \& Lundquist, C. J. 2009. Phylogeography of New Zealand's coastal benthos. N. Z. J. Mar. Freshw. Res. 43:1009-27.

Sanmartin, I., Wanntorp, L. \& Winkworth, R. C. 2007. West Wind Drift revisited: testing for directional dispersal in the Southern Hemisphere using eventbased tree fitting. J. Biogeogr. 34:398-416.

Shears, N. T., Smith, F., Babcock, R. C., Duffy, C. A. J. \& Villouta, E. 2008. Evaluation of biogeographic classification schemes for conservation planning: Application to New Zealand's coastal marine environment. Conserv. Biol. 22:467-81.

Tellier, F., Meynard, A. P., Correa, J. A., Faugeron, S. \& Valero, M. 2009. Phylogeographic analyses of the 30 degrees S south-east Pacific biogeographic transition zone establish the occurrence of a sharp genetic 
discontinuity in the kelp Lessonia nigrescens: Vicariance or parapatry? Mol. Phylogenet. Evol. 53:679-93.

Thiel, M. \& Haye, P. A. 2006. The ecology of rafting in the marine environment. III. Biogeographical and evolutionary consequences. Oceanography and Marine Biology: An Annual Review 44:323-429.

Waters, J. M. \& Roy, M. S. 2004. Phylogeography of a high-dispersal New Zealand sea-star: does upwelling block gene-flow? Mol. Ecol. 13:2797-806.

Wilson, J. R. U., Dormontt, E. E., Prentis, P. J., Lowe, A. J. \& Richardson, D. M. 2009. Something in the way you move: dispersal pathways affect invasion success. Trends Ecol. Evol. 24:136-44. 